\title{
\#USGS
}

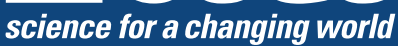

Prepared in cooperation with Pierce County Public Works and Utilities, Surface Water Managment

Channel-Conveyance Capacity, Channel Change, and Sediment Transport in the Lower Puyallup, White, and Carbon Rivers, Western Washington

Scientific Investigations Report 2010-5240 
Cover: Photograph showing view of Puyallup River from the Calistoga Road bridge looking upstream, with Mount Rainier in the distance, Orting, Washington. Photograph taken by Jonathan Czuba, U.S. Geological Survey, October 27, 2010. 


\section{Channel-Conveyance Capacity, Channel Change, and Sediment Transport in the Lower Puyallup, White, and Carbon Rivers, Western Washington}

By Jonathan A. Czuba, Christiana R. Czuba, Christopher S. Magirl, and Frank D. Voss

Prepared in cooperation with Pierce County Public Works and Utilities,

Surface Water Management

Scientific Investigations Report 2010-5240 


\title{
U.S. Department of the Interior \\ KEN SALAZAR, Secretary
}

\section{U.S. Geological Survey \\ Marcia K. McNutt, Director}

\section{U.S. Geological Survey, Reston, Virginia: 2010}

\author{
For more information on the USGS - the Federal source for science about the Earth, its natural and living resources, \\ natural hazards, and the environment, visit http://www.usgs.gov or call 1-888-ASK-USGS \\ For an overview of USGS information products, including maps, imagery, and publications, \\ visit http://www.usgs.gov/pubprod \\ To order this and other USGS information products, visit http://store.usgs.gov
}

Any use of trade, product, or firm names is for descriptive purposes only and does not imply endorsement by the U.S. Government.

Although this report is in the public domain, permission must be secured from the individual copyright owners to reproduce any copyrighted materials contained within this report.

Suggested citation:

Czuba, J.A., Czuba, C.R., Magirl, C.S., and Voss, F.D., 2010, Channel-conveyance capacity, channel change, and sediment transport in the lower Puyallup, White, and Carbon Rivers, western Washington: U.S. Geological Survey Scientific Investigations Report 2010-5240, 104 p. 


\section{Contents}

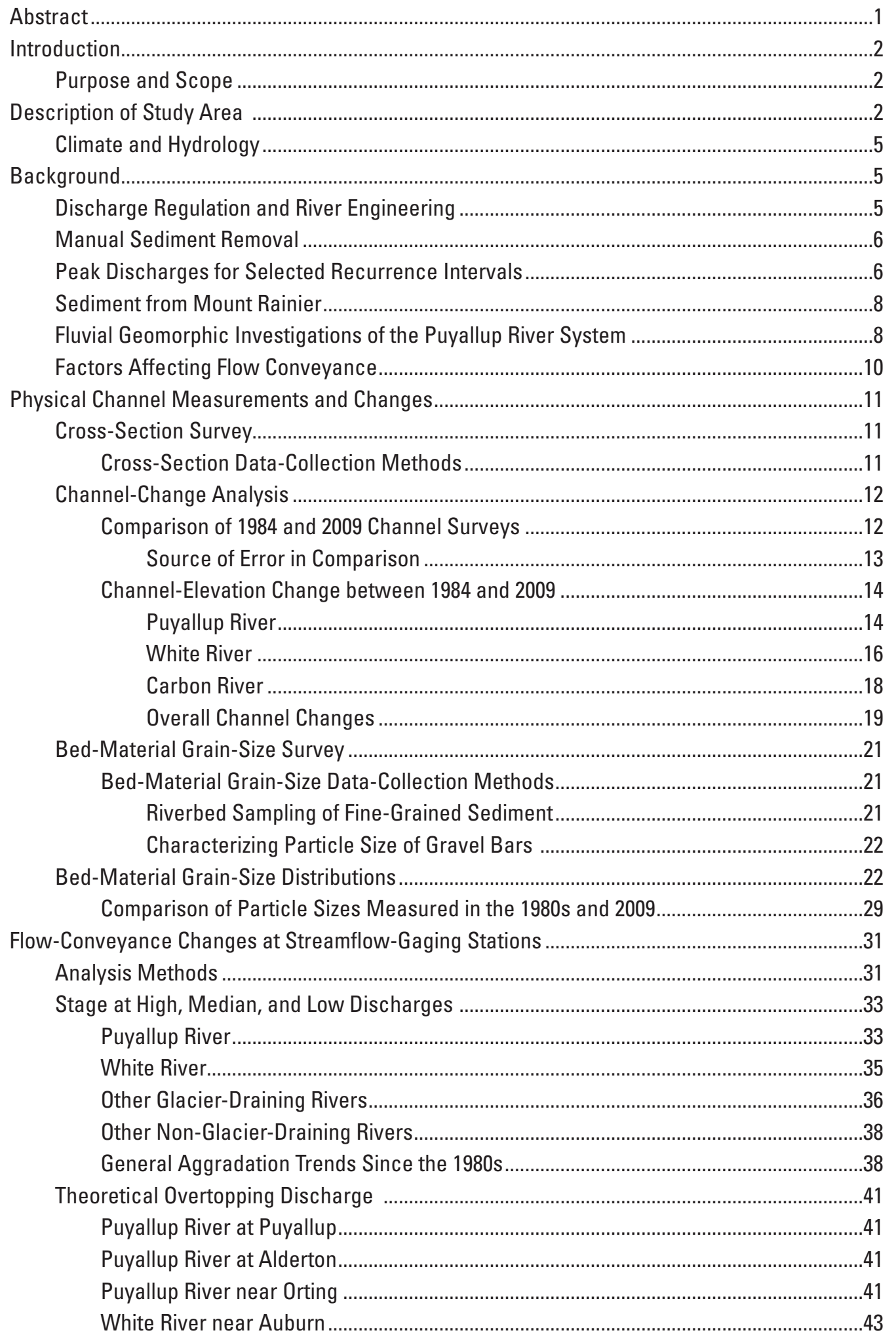




\section{Contents-Continued}

Flow Conveyance of the Puyallup, White, and Carbon Rivers .........................................................4

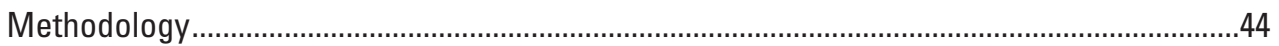

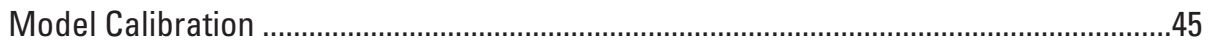

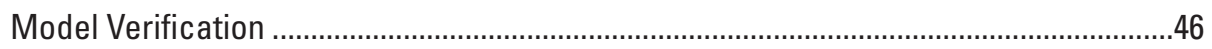

Model Comparison to Streamflow-Gaging Station Rating Curves .................................47

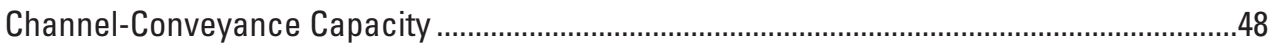

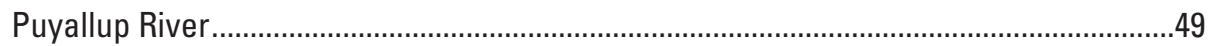

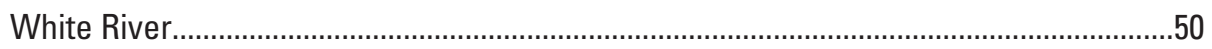

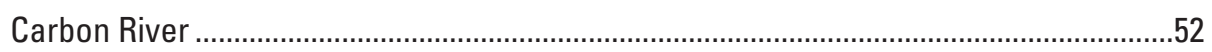

Comparison of Hydraulic Models..................................................................................

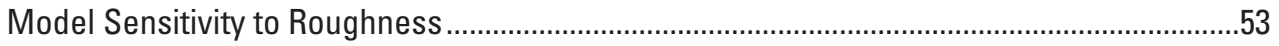

Flow-Conveyance Changes Related to Physical Channel Changes ..................................................55

Sediment Transport in the Puyallup, White, and Carbon Rivers ....................................................56

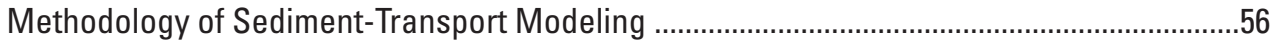

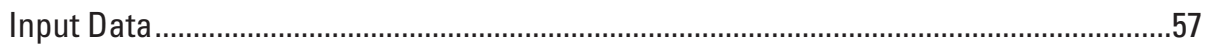

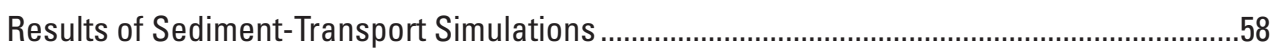

Simulated Annual Bedload Sediment Transport............................................................58

Simulated Average Annual Bedload Sediment Transport by Grain-Size Group for

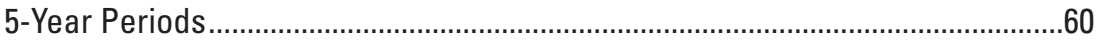

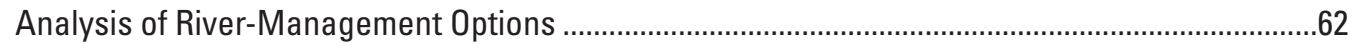

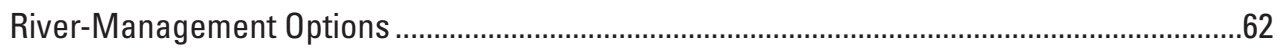

Methodology of River-Management-Option Simulations .....................................................63

River-Management Options for the Puyallup River in the Calistoga Reach ............................63

River-Management Options for the White River near the Pierce-King County Line ................68

River-Management Options for the Puyallup River near Sumner ..........................................74

General Trends and Considerations for River-Management Options......................................74

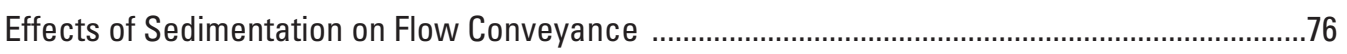

Sediment Trends Affecting Flow Conveyance ....................................................................

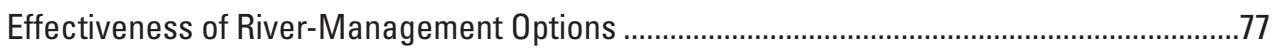

January 2009 Flooding of the White River at Pacific ...............................................................77

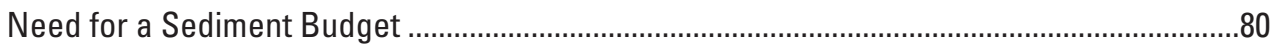

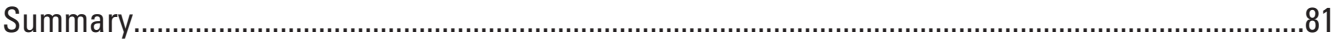

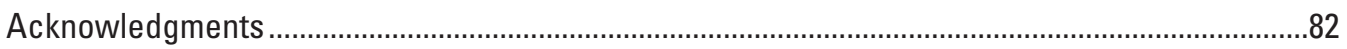

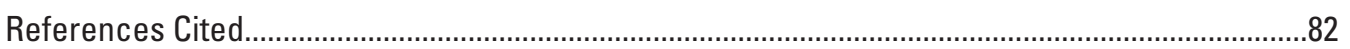

Appendix A. Cross Sections and River Miles in Study Area .......................................................

Appendix B. Temporal Trends at Selected Streamflow-Gaging Stations.........................................98

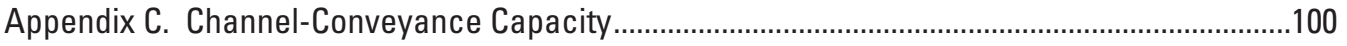




\section{Figures}

Figure 1. Map showing Puyallup River drainage basin on the northern flank of

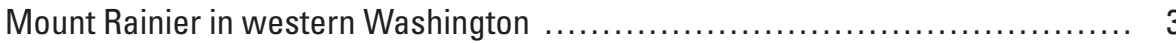

Figure 2. Map showing lower Puyallup River system study area, western Washington ..... 4

Figure 3. Graph showing comparison of average channel elevation at cross section P120, Puyallup River, Washington between 1984 and $2009 \quad \ldots \ldots \ldots \ldots \ldots \ldots \ldots \ldots$

Figure 4. Graph showing change in average channel elevation between 1984 and 2009 in the Puyallup River, western Washington

Figure 5. Graph showing change in bed volume between 1984 and 2009 in the Puyallup River, western Washington

Figure 6. Graph showing change in average channel elevation between 1984 and 2009 in the White River, western Washington 16

Figure 7. Graph showing change in bed volume between 1984 and 2009 in the White River, western Washington

Figure 8. Graph showing change in average channel elevation between 1984 and 2009 in the Carbon River, western Washington

Figure 9. Graph showing change in bed volume between 1984 and 2009 in the Carbon River, western Washington

Figure 10. Map showing change in average channel elevation between 1984 and 2009 in the Puyallup, White, and Carbon Rivers, western Washington

Figure 11. Photograph showing method used to transfer fine-grained sediment from the dredge to a sediment bag at cross section W51, White River, western Washington, November 4, 2009

Figure 12. Photograph showing method used to determine particle size of exposed cobble bars using the Wolman (1954) point-count method at cross section C35, Carbon River, western Washington, October 16, 2009

Figure 13. Graph showing measured sand distributions in the Puyallup and White Rivers, western Washington

Figure 14. Graph showing bed-material grain-size distributions for the Puyallup River, western Washington

Figure 15. Graph showing bed-material grain-size distributions for the White River, western Washington

Figure 16. Graph showing bed-material grain-size distributions for the Carbon River, western Washington

Figure 17. Graph showing thalweg elevation profiles using the 2009 cross sections for the Puyallup, White, and Carbon Rivers, western Washington

Figure 18. Map showing bed-material size gradations for the Puyallup, White, and Carbon Rivers, western Washington from data collected in 2009

Figure 19. Graph showing D50 grain size for particles greater than 2 millimeters measured in 2009 in the Puyallup, White, and Carbon Rivers, western Washington

Figure 20. Graph showing percentage of sand composing the bed material measured in 2009 compared to the slope in the Puyallup, White, and Carbon Rivers, western Washington

Figure 21. Graph showing comparison of the D50 grain size for particles greater than 2 millimeters measured in 2009 to those measured by Sikonia (1990) for the Puyallup River, western Washington 


\section{Figures-Continued}

Figure 22. Graph showing comparison of the D50 grain size for particles greater than 2 millimeters measured in 2009 to those measured by Sikonia (1990) for the White River, western Washington

Figure 23. Graph showing comparison of the D50 grain size for particles greater than 2 millimeters measured in 2009 to those measured by Sikonia (1990) for the Carbon River, western Washington

Figure 24. Graph showing stage for the period of record at 10, 50, and 90 percent exceedance for gaging station 12101500, Puyallup River at Puyallup, Washington

Figure 25. Graph showing stage for period of record at 10,50, and 90 percent exceedance for gaging station 12092000, Puyallup River near Electron, Washington

Figure 26. Graph showing stage for the period of record at 10,50, and 90 percent exceedance for gaging station 12100496, White River near Auburn,

Washington

Figure 27. Graph showing stage for the period of record at 10,50, and 90 percent exceedance for gaging station 12098500, White River near Buckley, Washington

Figure 28. Graph showing stage for the period of record at 10, 50, and 90 percent exceedance for station 12082500, Nisqually River near National, Washington

Figure 29. Graph showing stage for the period of record at 10,50, and 90 percent exceedance for gaging station 14226500, Cowlitz River at Packwood, Washington

Figure 30. Map showing trends in aggradation for 12 streamflow-gaging stations surrounding Mount Rainier primarily in the Puyallup River drainage basin, western Washington ....

Figure 31. Map showing standard deviation in stage at median discharge for 12 streamflow-gaging stations surrounding Mount Rainier primarily in the Puyallup River drainage basin, western Washington

Figure 32. Graph showing long-term trends in the theoretical overtopping discharge and discharge measurements at USGS streamflow-gaging station 12101500, Puyallup River at Puyallup, Washington

Figure 33. Graph showing long-term trends in the theoretical overtopping discharge and discharge measurements at USGS streamflow-gaging station 12096500, Puyallup River near Alderton, Washington

Figure 34. Graph showing long-term trends in the theoretical overtopping discharge and discharge measurements at USGS streamflow-gaging station 12093500, Puyallup River near Orting, Washington

Figure 35. Graph showing long-term trends in the theoretical overtopping discharge and discharge measurements at USGS streamflow-gaging station 12100496, White River near Auburn, Washington

Figure 36. Graph showing long-term trends in water-surface elevations for discharges at 9,000 and 12,000 ft3/s at USGS streamflow-gaging station 12100496,

White River near Auburn, Washington 


\section{Figures-Continued}

Figure 37. Graph showing normalized discharge and difference in water-surface elevation between model-simulated rating curves at nearby cross sections and rating curves calculated from measurements at four USGS streamflow-gaging stations in the Puyallup and White Rivers, western Washington

Figure 38. Graph showing simulated channel-conveyance capacity for the lower

Puyallup River, western Washington, 1984 and 2009

Figure 39. Graph showing simulated channel-conveyance capacity for the middle Puyallup River, western Washington, 1984 and 2009

Figure 40. Graph showing simulated channel-conveyance capacity for the upper Puyallup River, western Washington, 1984 and 2009

Figure 41. Graph showing simulated channel-conveyance capacity for the White River, western Washington, 1984 and 2009

Figure 42. Graph showing simulated channel-conveyance capacity for the Carbon River, western Washington, 1984 and 2009

Figure 43. Graph showing sensitivity of the 2009 simulated 100 -year recurrence-interval water-surface elevations to simulated changes in roughness for the Puyallup River, western Washington

Figure 44. Graph showing sensitivity of the 2009 simulated 100 -year recurrence-interval water-surface elevations to changes in roughness for the White River, western Washington

Figure 45. Graph showing sensitivity of the 2009 simulated 100 -year recurrence-interval water-surface elevations to changes in roughness for the Carbon River, western Washington

Figure 46. Graph showing simulated annual bedload as a function of river location for the Puyallup River, western Washington, water years 1999-2003 and 2005-09

Figure 47. Graph showing simulated annual bedload as a function of river location for the White River, western Washington, water years 1999-2004 and 2005-09....... 59

Figure 48. Graph showing simulated annual bedload as a function of river location for the Carbon River, western Washington, water years 1999-2003 and 2005-09.

Figure 49. Graph showing simulated annual bedload by grain size for each simulation period for the Puyallup River, western Washington, water years 1999-2003 and 2005-09

Figure 50. Graph showing simulated annual bedload by grain size for each simulation period for the White River, western Washington, water years 1999-2003 and 2005-09

Figure 51. Graph showing simulated annual bedload by grain size for each simulation period for the Carbon River, western Washington, water years 1999-2003 and 2005-09

Figure 52. Map showing Calistoga reach river-management site along the Puyallup River, western Washington ....

Figure 53. Graph showing simulated initial change in water-surface elevation at a discharge of 18,000 cubic feet per second from management modification relative to the baseline condition for the Calistoga reach along the Puyallup River, western Washington 


\section{Figures-Continued}

Figure 54. Graph showing simulated cumulative bed-volume change after 90 days at a discharge of 18,000 cubic feet per second in the Calistoga reach along the Puyallup River, western Washington

Figure 55. Graph showing simulated cumulative bed-volume change at a discharge of 18,000 cubic feet per second for sediment management options in the Calistoga reach along the Puyallup River, western Washington

Figure 56. Graph showing simulated water-surface elevation change after 90 days at a discharge of 18,000 cubic feet per second for the Calistoga reach along the Puyallup River, western Washington

Figure 57. Map showing Countyline reach river-management site along the White River, western Washington

Figure 58. Graph showing simulated initial change in the water-surface elevation at a discharge of 14,000 cubic feet per second from management modification relative to the baseline condition for the Countyline reach along the White River, western Washington

Figure 59. Graph showing simulated cumulative bed-volume change after 90 days at a discharge of 14,000 cubic feet per second in the Countyline reach along the White River, western Washington

Figure 60. Graph showing simulated cumulative bed-volume change at a discharge of 14,000 cubic feet per second for sediment management options in the setback-levee Countyline reach along the White River, western Washington

Figure 61. Graph showing simulated water-surface elevation change after 90 days at a discharge of 14,000 cubic feet per second for the Countyline reach along the White River, western Washington

Figure 62. Graph showing simulated annual bed-volume change in the setback levee section for the Countyline reach along the White River, western Washington, water years 1999-2003 and 2005-09, for different river-management options

Figure 63. Map showing Sumner reach river-management site along the Puyallup River, western Washington

Figure 64. Graph showing simulated initial change in the water-surface elevation at a discharge of 43,500 cubic feet per second from management modification relative to the baseline condition for the Sumner Reach along the Puyallup River, western Washington

Figure 65. Graphs showing comparison of discharge and stage for the White River near Auburn for 10-day periods starting November 12, 2008 and January 6, 2009

Figure 66. Graphs showing changes in mean channel elevation between 1984 and 2009 for surveyed cross sections, and channel-conveyance capacity determined with one-dimensional hydraulic modeling for the White River near Auburn, Washington 


\section{Tables}

Table 1. Volume of sediment removed from the Puyallup, White, and Carbon Rivers, western Washington, 1974-2009

Table 2. Recurrence-interval peak discharges in the study area during Puyallup River peak discharges, western Washington

Table 3. Recurrence-interval peak discharges in the study area during White River peak discharges, western Washington

Table 4. Recurrence-interval peak discharges for the Puyallup, White, and Carbon Rivers, western Washington

Table 5. Size classes for sediment

Table 6. Streamflow-gaging stations in the study area analyzed for trends in stage for selected streamflow-gaging stations in western Washington

Table 7. Trends and variability of aggradation and standard deviation at the median discharge for selected streamflow-gaging stations in western Washington $\quad \ldots \ldots 38$

Table 8. Discharges used for calibration of the one-dimensional model of the Puyallup, White, and Carbon Rivers, western Washington

Table 9. Difference between model-simulated and measured water-surface elevations for hydrologic conditions at four gaging stations, western Washington, May 31, 2009 at 12:00 PM

Table 10. Discharges used for verification of the one-dimensional model of the Puyallup, White, and Carbon Rivers, western Washington

Table 11. Difference between model simulated and measured water-surface elevations at four gaging stations for hydrologic conditions, western Washington, January 12, 2009 at 12:00 PM 


\section{Conversion Factors, Datums, and Abbreviations and Acronyms}

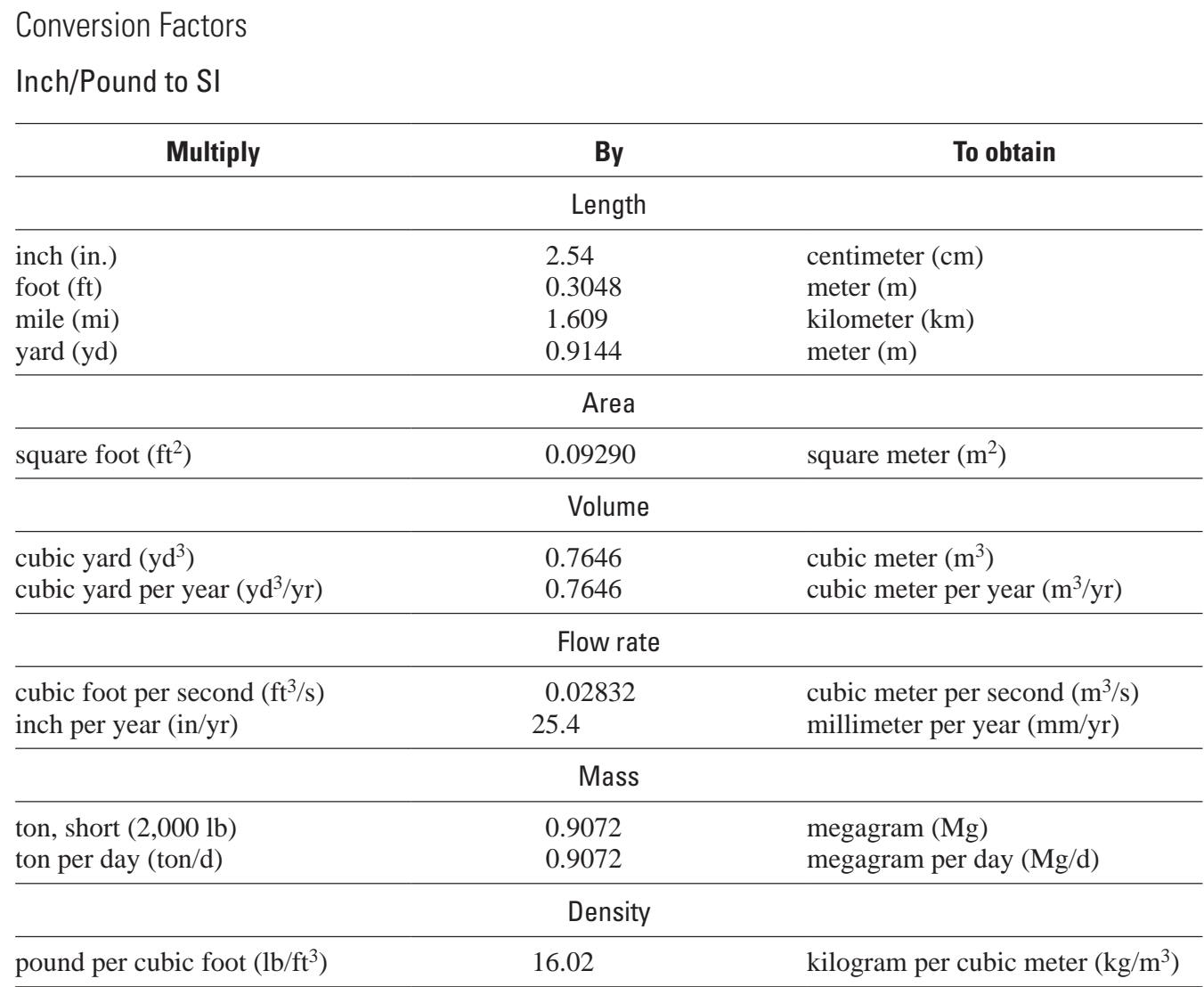

SI to Inch/Pound

\begin{tabular}{|c|c|c|}
\hline Multiply & By & To obtain \\
\hline \multicolumn{3}{|c|}{ Length } \\
\hline millimeter (mm) & 0.03937 & inch (in.) \\
\hline
\end{tabular}

Temperature in degrees Celsius $\left({ }^{\circ} \mathrm{C}\right)$ may be converted to degrees Fahrenheit $\left({ }^{\circ} \mathrm{F}\right)$ as follows:

$$
{ }^{\circ} \mathrm{F}=\left(1.8 \mathrm{x}^{\circ} \mathrm{C}\right)+32 \text {. }
$$




\section{Conversion Factors, Datums, and Abbreviations and Acronyms-Continued}

Datums

Vertical coordinate information is referenced to the North American Vertical Datum of 1988 (NAVD 88) in U.S. Survey feet.

Horizontal coordinate information is referenced to the North American Datum of 1983 (NAD 83)

High Accuracy Reference Network (HARN), State Plane Washington South, in U.S. Survey feet.

Altitude, as used in this report, refers to distance above the vertical datum.

Abbreviations and Acronyms

$\begin{array}{ll}\text { ADCP } & \text { acoustic Doppler current profiler } \\ \text { CVO } & \text { Cascades Volcano Observatory } \\ \text { dGPS } & \text { differential global positioning system } \\ \text { FEMA } & \text { Federal Emergency Management Agency } \\ \text { GIS } & \text { geographic information system } \\ \text { GPS } & \text { global positioning system } \\ \text { HEC-RAS } & \text { Hydrologic Engineering Center River Analysis System } \\ \text { ICRI } & \text { Inter-County River Improvement } \\ \text { LiDAR } & \text { Light Detection and Ranging } \\ \text { MMD } & \text { Mud Mountain Dam } \\ \text { NOAA } & \text { National Oceanic and Atmospheric Administration } \\ \text { NWIS } & \text { National Water Information System } \\ \text { PCRI } & \text { Pierce County River Improvement } \\ \text { RM } & \text { river mile } \\ \text { RTN } & \text { real-time kinematic network } \\ \text { USACE } & \text { U.S. Army Corps of Engineers } \\ \text { USGS } & \text { U.S. Geological Survey } \\ \text { WSDOT } & \text { Washington State Department of Transportation } \\ \text { WY } & \text { water year }\end{array}$


This page intentionally left blank. 


\title{
Channel-Conveyance Capacity, Channel Change, and Sediment Transport in the Lower Puyallup, White, and Carbon Rivers, Western Washington
}

\author{
By Jonathan A. Czuba, Christiana R. Czuba, Christopher S. Magirl, and Frank D. Voss
}

\section{Abstract}

Draining the volcanic, glaciated terrain of Mount Rainier, Washington, the Puyallup, White, and Carbon Rivers convey copious volumes of water and sediment down to Commencement Bay in Puget Sound. Recent flooding in the lowland river system has renewed interest in understanding sediment transport and its effects on flow conveyance throughout the lower drainage basin. Bathymetric and topographic data for 156 cross sections were surveyed in the lower Puyallup River system by the U.S. Geological Survey (USGS) and were compared with similar data sets collected in 1984. Regions of significant aggradation were measured along the Puyallup and White Rivers. Between 1984 and 2009, aggradation totals as measured by changes in average channel elevation were as much as 7.5, 6.5, and 2 feet on the Puyallup, White, and Carbon Rivers, respectively. These aggrading river sections correlated with decreasing slopes in riverbeds where the rivers exit relatively confined sections in the upper drainage and enter the relatively unconstricted valleys of the low-gradient Puget Lowland. Measured grain-size distributions from each riverbed showed a progressive fining downstream.

Analysis of stage-discharge relations at streamflow-gaging stations along rivers draining Mount Rainier demonstrated the dynamic nature of channel morphology on river courses influenced by glaciated, volcanic terrain. The greatest rates of aggradation since the 1980s were in the Nisqually River near National (5.0 inches per year) and the White River near Auburn (1.8 inches per year). Less pronounced aggradation was measured on the Puyallup River and the White River just downstream of Mud Mountain Dam. The largest measured rate of incision was measured in the Cowlitz River at Packwood (5.0 inches per year).

Channel-conveyance capacity estimated using a onedimensional hydraulic model decreased in some river reaches since 1984. The reach exhibiting the largest decrease (about 20-50 percent) in channel-conveyance capacity was the White
River between R Street Bridge and the Lake Tapps return, a reach affected by recent flooding. Conveyance capacity also decreased in sections of the Puyallup River. Conveyance capacity was mostly unchanged along other study reaches. Bedload transport was simulated throughout the entire river network and consistent with other observations and analyses, the hydraulic model showed that the upper Puyallup and White Rivers tended to accumulate sediment. Accuracy of the bedload-transport modeling, however, was limited due to a scarcity of sediment-transport data sets from the Puyallup system, mantling of sand over cobbles in the lower Puyallup and White Rivers, and overall uncertainty in modeling sediment transport in gravel-bedded rivers. Consequently, the output results from the model were treated as more qualitative in value, useful in comparing geomorphic trends within different river reaches, but not accurate in producing precise predictions of mass of sediment moved or deposited.

The hydraulic model and the bedload-transport component were useful for analyzing proposed river-management options, if surveyed cross sections adequately represented the river-management site and proposed management options. The hydraulic model showed that setback levees would provide greater flood protection than gravel-bar scalping after the initial project construction and for some time thereafter, although the model was not accurate enough to quantify the length of time of the flood protection. The greatest hydraulic benefit from setback levees would be a substantial increase in the effective channel-conveyance area. By widening the distance between levees, the new floodplain would accommodate larger increases in discharge with relatively small incremental increases in stage. Model simulation results indicate that the hydraulic benefit from a setback levee also would be long-lived and would effectively compensate for increased deposition within the setback reach from increased channel-conveyance capacity. In contrast, the benefit from gravel-bar scalping would be limited by the volume of material that could be removed and the underlying hydraulics in the river section that would be mostly unaffected by scalping. 
Finally, the study formulated an explanation of the flooding that affected Pacific, Washington, in January 2009. Reduction in channel-conveyance capacity of about 25 percent at the White River near Auburn streamflow-gaging station between November 2008 and January 2009 was caused by rapid accumulation of coarse-grained sediment just downstream of the gage, continuing an ongoing trend of aggradation that has been documented repeatedly.

\section{Introduction}

Recent flooding along the lower Puyallup River system in Washington State (Mastin and others, 2010) has renewed interest in understanding the current channel-conveyance capacity of the river network, trends in channel-conveyance capacity since the 1980s when numerous studies characterized sedimentation trends (Dunne, 1986; Prych, 1988; Sikonia, 1990), and possible future channel-conveyance capacity for different river-management options. As recently as the 1990s, large volumes of sediment commonly were removed from selected reaches of the river network in the Puget Lowland (Prych, 1988; Herrera Environmental Consultants, 2010), thereby offsetting copious sediment input from the upper drainage basin (Nelson, 1979; Dunne, 1986; Sikonia, 1990). Since the mid-1990s, however, sediment removal (that is, gravel-bar dredging and scalping) has largely ceased along all rivers in the Puyallup River system, partly to prevent adverse effects on aquatic habitat of federally-listed, threatened, and endangered salmonids. Chinook salmon [Oncorhynchus tshawytscha] and steelhead [O. mykiss] are listed as threatened in Puget Sound and coho salmon [O. kisutch] is listed as a species of concern (National Oceanic and Atmospheric Administration, 2010b). Reductions in river-maintenance budgets and the recognition that flood-reduction benefits from gravel removal are temporary are other factors contributing to the cessation of gravel-removal activity in the region. It is not known how this shift in river-management strategy has affected the long-term trends in channel-conveyance capacity of the lower Puyallup River system. Pierce County and other resource managers in the basin are developing a flood-hazardmanagement plan and, as part of the plan, are considering setback levees and targeted gravel-bar scalping to mitigate channel-bed aggradation and reduce flooding risk without affecting critical aquatic habitat. To assist with development of the plan, Pierce County requested that the U.S. Geological Survey (USGS) conduct this cooperative study of the lower Puyallup River system.

The objectives of the study were to (1) determine the spatial and temporal trends of sediment deposition and scour in the lower Puyallup River system since 1984, (2) determine the long-term changes in water-surface elevation and channelconveyance capacity at specific USGS streamflow-gaging stations distributed in the Puyallup River drainage basin, (3) estimate the 2009 channel-conveyance capacity in the lower Puyallup River system, and (4) evaluate the effects of selected river-management options, such as setback levees and sediment removal by gravel-bar scalping, on channel conveyance and sedimentation of the lower Puyallup River system.

\section{Purpose and Scope}

This report documents an analysis of the historical trends in channel-conveyance capacity of the lower Puyallup River system, describes sediment transport through the system, and evaluates the potential effects of different river-management strategies on these factors. The historical trends in channel change were analyzed using cross sections surveyed in 2009 by the USGS and King County (river miles [RM] 5-10 in the lower White River; Herrera Environmental Consultants, 2010) and compared to cross sections surveyed in 1984 (Prych, 1988) in the lower $26 \mathrm{mi}$ of the Puyallup River, the lower $10.5 \mathrm{mi}$ of the White River, and the lower $6 \mathrm{mi}$ of the Carbon River. Channel changes also were analyzed through 2009 using data from 12 USGS streamflow-gaging stations located in the greater Mount Rainier drainage basin. A hydraulic and sediment-transport model was developed based on cross-section geometries surveyed in 2009 by the USGS for this study (92 cross sections) and for the U.S. Army Corps of Engineers (64 cross sections) in the lower $28.9 \mathrm{mi}$ of the Puyallup River, lower $5 \mathrm{mi}$ of the White River, and lower $8.4 \mathrm{mi}$ of the Carbon River, and by King County (50 cross sections) between RMs 5 and 10 in the lower White River (Herrera Environmental Consultants, 2010). The hydraulic model simulated the 2009 channel-conveyance capacity in the lower Puyallup River system with the same discharges used by Prych (1988) for a similar analysis. The sedimenttransport model incorporated bed-material grain sizes measured by the USGS in 2009 co-located with 30 channel cross sections in the study area and bedload data from Sikonia (1990). The sediment-transport model was used to simulate sediment transport for water years 1999-2003 and 2004-09 under current conditions and under three possible future river-management options selected by Pierce County.

\section{Description of Study Area}

The Puyallup River basin drains about $990 \mathrm{mi}^{2}$ in western Washington (fig. 1). Elevation in the basin ranges from about $14,410 \mathrm{ft}$ at the top of Mount Rainier in the Cascade Range to sea level at the mouth of the river in Commencement Bay, a distance of 50-90 mi, depending on river course. The Cascade Range and its foothills span most of the southeastern part of the drainage basin (fig. 1) and about 49 percent of the drainage basin consists of terrain with hill slopes greater than 30 percent (U.S. Geological Survey, 2010a). The steep stream gradients, ample precipitation, and presence of a glaciated volcano at the headwaters contribute to large rates of downstream sediment transport. 


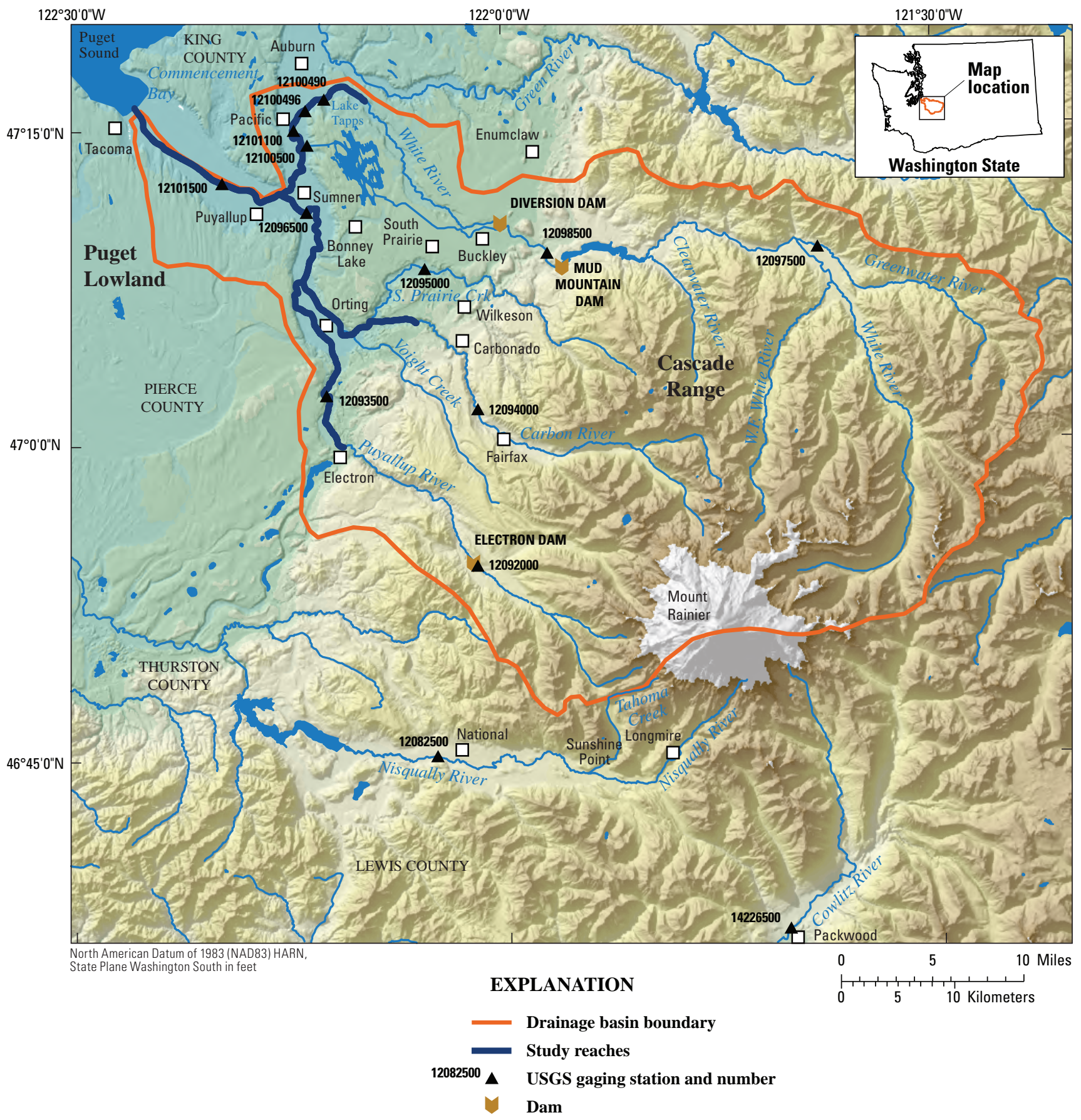

Figure 1. Puyallup River drainage basin on the northern flank of Mount Rainier in western Washington.

The study area in the lower Puyallup River system in the Puget Lowland (fig. 2) includes the main channels of the Puyallup, White, and Carbon Rivers. Local river miles are used in most cases in this report to describe positions along the Puyallup, White, and Carbon Rivers and are defined relative to the distance upstream of the mouth of each river. Basin river miles are used only when specified and describe positions along the Puyallup, White, and Carbon Rivers relative to the mouth of the Puyallup River at Commencement Bay. In this study, the lower Puyallup River is defined as the river reach from Commencement Bay (RM 0.0) to the confluence with the White River (RM 10.3), the middle Puyallup River is defined as the river reach from the White River to the confluence with the Carbon River (RM 17.7), and the upper Puyallup River is defined as the river reach from the Carbon River upstream to RM 28.9. The study area for the White River extended from the Puyallup River upstream to RM 10.5; the study area for the Carbon River extended from the Puyallup River upstream to RM 8.4. 


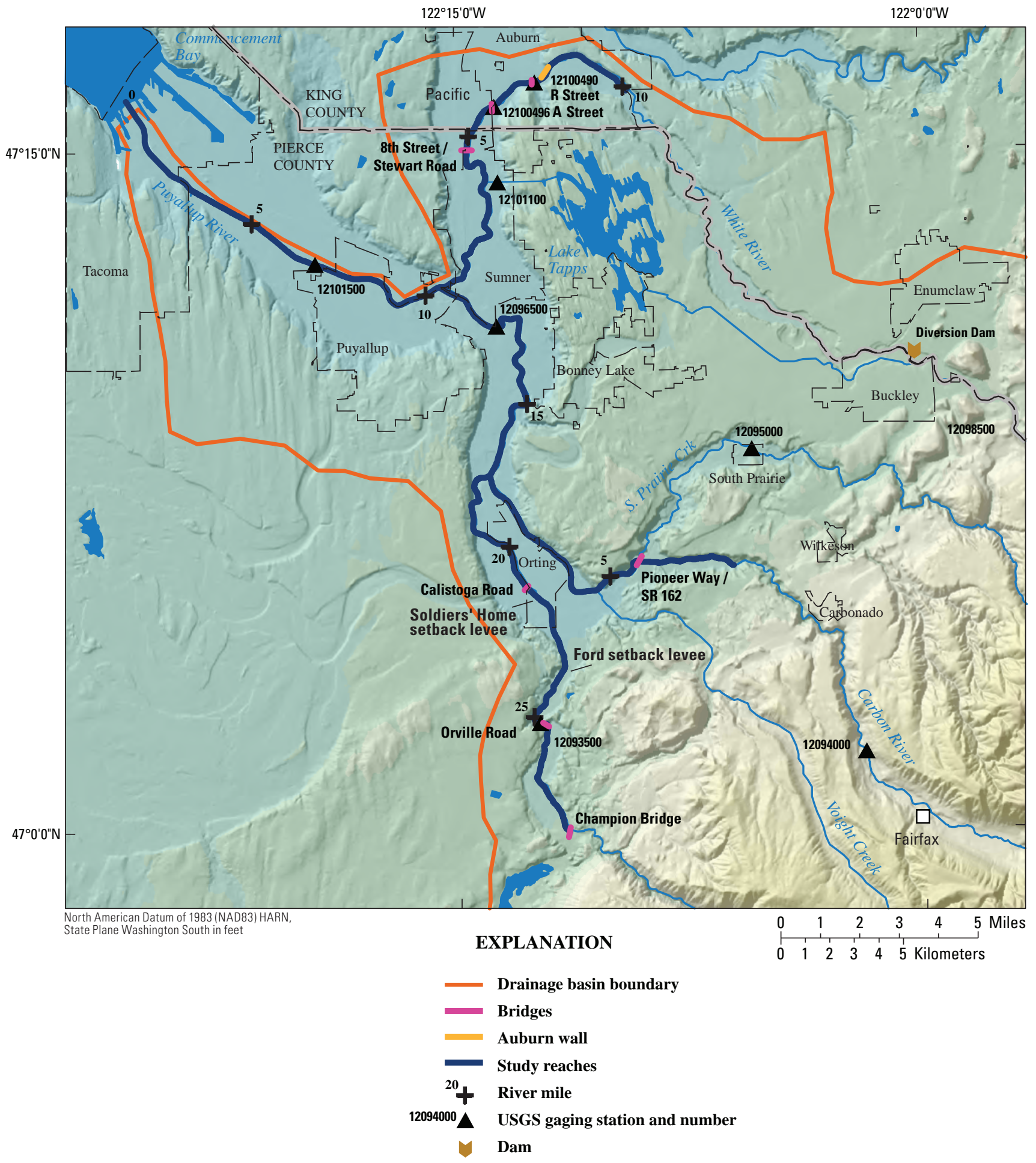

Figure 2. Lower Puyallup River system study area, western Washington. 


\section{Climate and Hydrology}

The climate of the study area is predominantly wet and temperate (National Oceanic and Atmospheric Administration, 2010a). The prevailing wind direction is from the south or southwest during the rainy season (October to June) and from the northwest during the relatively dry summer from July to September (National Oceanic and Atmospheric Administration, 2010a). Occasionally during winter, cold air from the Canadian interior flows southward and covers the Puget Lowland. The average January maximum temperature is about $43^{\circ} \mathrm{F}$ and the minimum is about $30^{\circ} \mathrm{F}$. During July, the average maximum temperature is about $75^{\circ} \mathrm{F}$ and the minimum is about $50^{\circ} \mathrm{F}$. In the Puget Lowland, winter temperatures decrease inland from Puget Sound and summer temperatures increase. Annual precipitation in the Puget Lowland is approximately $40 \mathrm{in}$., and the winter snowfall is about $15 \mathrm{in}$. This lowland snow generally melts quickly and snow depths rarely exceed 6 in. Precipitation increases with elevation away from the Puget Sound. Annual rainfall in the Cascade Range of the upper basin typically is $60-100$ in. and total annual snowfall is between 400 and 600 in. at elevations of 4,000-5,500 ft (National Oceanic and Atmospheric Administration, 2010a).

Mean annual discharge for the Puyallup River near Puyallup, Wash. (USGS streamflow-gaging station $12101500)$ is $3,321 \mathrm{ft}^{3} / \mathrm{s}$ for 95 years of record (1914-2009; U.S. Geological Survey, 2010b) with dominant hydrologic inputs from rainfall in winter and snowmelt in spring and summer. Late summer and autumn discharge is sustained by groundwater discharge, snowmelt, and glacial-melt water from Mount Rainier. The headwaters of the Puyallup, White, and Carbon Rivers all originate from the glaciers on Mount Rainier. The largest peak discharges in the drainage basin are associated with autumn or winter rain-on-snow precipitation events. At Puyallup River at Puyallup (gaging station 12101500), the flood of record of 57,000 ft $3 / \mathrm{s}$ was in December 1933. For this lower Puyallup River site, 6 of the 10 largest annual peak discharges have occurred since 1987, including 48,200 ft $\mathrm{ft}^{3} / \mathrm{s}$ on January 8, 2009 (2nd largest peak in the record) and 39,700 ft $\mathrm{ft}^{3} / \mathrm{s}$ on November 7, 2006 (10th largest peak in the record). At higher elevations in the drainage basin, this November 2006 peak established peaks of record for the Carbon River near Fairfax, Wash. (14,500 ft $3 / \mathrm{s}$ at gaging station 12094000) and on the Puyallup River near Orting $\left(21,500 \mathrm{ft}^{3} / \mathrm{s}\right.$ at gaging station 12093500). Widespread flooding also affected the region in February 1996 when discharge peaked at $46,700 \mathrm{ft}^{3} / \mathrm{s}$ on the Puyallup River at Puyallup (third largest peak in the record). Smaller peak discharges usually occur in late spring and early summer with the seasonal snowmelt.

\section{Background}

Major modifications to the Puyallup River system have occurred over the past century including river-channel realignment, levee construction, sediment removal, and dam construction. Numerous studies have contributed to the current understanding of sediment production from Mount Rainier and its effect on the fluvial geomorphology of the lower Puyallup River system.

\section{Discharge Regulation and River Engineering}

Three dams are in the basin: Mud Mountain Dam (MMD) on the White River is used for flood control, a diversion dam on the White River near Buckley supplements surface water to Lake Tapps, and Electron Dam on the Puyallup River is a runof-the-river structure used for power generation (fig. 1).

The U.S. Army Corps of Engineers (USACE) operates MMD to control flooding on the lower Puyallup River. The primary objective of MMD is to limit the Puyallup River peak discharge at USGS streamflow-gaging station 12101500 , Puyallup River at Puyallup, Wash., to less than $45,000 \mathrm{ft}^{3} / \mathrm{s}$. A secondary objective in dam operations is to control flooding on the White River by limiting releases to $12,000 \mathrm{ft}^{3} / \mathrm{s}$. During peak discharge, flow on the White River is retained by MMD until the flood peak on the lower Puyallup River has abated, at which time releases from MMD are increased to evacuate water and regain reservoir capacity in preparation for the next storm (U.S. Army Corps of Engineers, 2009). The intake structure of the dam and two pass-through tunnels are near the elevation of the channel invert of the White River; the reservoir is empty for much of the year, which allows the river to flow through the dam reach at a grade similar to the pre-dam river profile. Unlike other dams where trap efficiency of bedload can approach 100 percent, MMD passes significant volumes of bedload containing particles as large as boulders (Rick Emry, U.S. Army Corps of Engineers, written commun., 2010). The trash rack on the intake structure passes all sediment smaller than 18 in.; larger clasts sieved by the trash rack are manually removed with heavy equipment (Rick Emry, U.S. Army Corps of Engineers, written commun., 2010). The dam also is an effective trap for large woody debris, all of which is removed manually in spring and summer and used for engineering and habitat-restoration projects. When retaining flow, water pools in the reservoir and deposits large volumes of sand and coarser particles, which accumulate to depths as much as $40 \mathrm{ft}$ (Rick Emry, U.S. Army Corps of Engineers, written commun., 2010). When the flood threat passes, in winter between storms and in spring and summer during the seasonal snowmelt, sediment is sluiced through the dam and passed downstream in a fashion that prevents aggradation of the channel invert at the intake structure. 
Lake Tapps currently (2010) is operated by Cascade Water Alliance. Water is diverted from the White River near Buckley (RM 24.3) through the Lake Tapps diversion and then is returned to the White River near Dieringer (RM 3.6). The diverted water can contain a large amount of sand, which deposits in settling basins in the flume. Sediment was last removed from this settling basin in 2003 and sediment removal was scheduled for August 2010 (Joe Mickelson, Cascade Water Alliance, oral commun., 2010).

Electron Dam is operated by Puget Sound Energy. This dam has minimal storage capacity and has almost no effect on peak discharges because it ceases diversions during large discharges.

The Puyallup, White, and Carbon Rivers in the study area have been confined by levees and revetments for most of their lengths. Major modifications to the river channels were made in the early 1900s and modifications continued through the 1960s. Prior to the early 1900s, the White River naturally would change course and at times would discharge north into the Green River and at other times south into the Puyallup River. After a 1906 flood directed the White River to the south into what was once called the Stuck River channel (currently the White River downstream of the Auburn wall) (Prych, 1988), the river-course realignment was made permanent with the construction of a hardened revetment, referred to as the Auburn wall (fig. 2). Since the early 1970s, most modifications have been limited to repair and maintenance of the constructed channel. This work has included repairing damaged sections of levees, dredging the river bed and gravel bars, and cutting vegetation from stream banks when it increased channel roughness or reduced the structural integrity of levees. Vegetation along the river banks provides shade for fish. Removal of vegetation was greatly reduced after the vegetation-management agreement was reached between Pierce County and the Puyallup Tribe of Indians in 1985. Recently, Pierce County has been removing sections of old levees and revetments and constructing setback levees to restore connectivity with the floodplain, provide enhanced flood storage, and improve habitat. On the Puyallup River, prominent completed setback projects include the 1998 Ford-Hatten-Filbin setback levee along the right bank between RM 23.4-25.0, reconnecting 122 acres of floodplain, and the 2006 Soldiers' Home setback levee along the left bank between RM 21.5 - 22.4, reconnecting 67 acres of floodplain (Lorin Reinelt, Pierce County, written commun., 2010).

\section{Manual Sediment Removal}

Gravel was routinely removed from the Puyallup, White, and Carbon Rivers as part of ongoing efforts during the 20th century to reduce the risk of flooding along the Puyallup River system (Prych, 1988; Herrera Environmental Consultants, 2010). For example, quantitative records from Inter-County River Improvement (ICRI) indicate about 2 million cubic yards of sediment were removed from the White River between 1914 and 1932 (Herrera Environmental Consultants, 2010). Prych (1988) interpreted incision along the Puyallup River in the 1930s as a response to gravel extraction, and also reported that $600,000 \mathrm{yd}^{3}$ of sediment were dredged from the downstream-most $1 \mathrm{mi}$ of the Puyallup River in 1963. The amount of recent gravel removal is better quantified. The record of known sediment removal (volume and location) in the study area between 1974 and 1983 was reported by Prych (1988) and updated by Pierce County (Sarah Motsenbocker, Pierce County, written commun., 2010) (table 1). Between 1974 and 1987, annual removal of hundreds of thousands of cubic yards of sediment from the Puyallup, White, and Carbon Rivers was common. Pierce County River Improvement (PCRI), ICRI, and private contractors removed most of these sediments. Increased restrictions placed on the issuance of permits and tightened enforcement of those restrictions caused PCRI/ICRI to reduce the gravel removal volumes between 1988 and 1998. Dredging in Pierce County was stopped in the late 1980s. By 1994, Washington State prohibited dredging to lower the average channel cross-section profile (Washington Administrative Code 220-110-140). Manual gravel removal ceased after 1998 partly because of greater permitting requirements due to awareness of the effects of gravel removal on threatened salmonids.

From 1984 to 1998, gravel was removed from the Puyallup River from RM 14.2 to RM 23.6 and from RM 27.2 to RM 27.4; most of the gravel removal was between RMs 15.8 and 23.6. In the White River, gravel was removed from RM 3.6 to RM 6.5 and from RM 7.8 to RM 8.5; most of the gravel removal was between RMs 3.6 and 5.6. In the Carbon River, gravel was removed from RMs 0 to 1.5 and from RMs 5.6 to 6.8. The methods of gravel removal changed over time. During the 1970s and 1980s, excavation of several feet below grade from a dry channel adjacent to the main channel was common. Photography indicates that, at times, the entire active channel was dredged (Lorin Reinelt, Pierce County, written commun., 2010). Those invasive removal techniques stopped in the mid- to late-1980s due to concerns about effects on salmonid habitat and gravel-bar scalping; removal of sediment from the top of bars exposed above the low-discharge water line became prevalent in the 1990s.

\section{Peak Discharges for Selected Recurrence Intervals}

Annual-exceedance probability often is used to characterize flood frequency, and is the inverse of the recurrence interval. For example, an annual peak discharge with an exceedance probability of 0.02 is equivalent to a 50 -year recurrence-interval peak discharge $(1 / 0.02=50)$, which has a statistical probability of being equaled or exceeded two times in 100 years on average or a 2-percent chance of being equaled or exceeded in any 1 year. 
Table 1. Volume of sediment removed from the Puyallup, White, and Carbon Rivers, western Washington, 1974-2009.

[Data before 1983 assembled by Prych (1988). Data after 1984 assembled by Pierce County (Sarah Motsenbocker, Pierce County, written commun., 2010). $>0$ means gravel removal occurred, but no specific quantities are available.

Abbreviations $\mathrm{yd}^{3}$, cubic yard; >, greater than]

\begin{tabular}{|c|c|c|c|c|}
\hline \multirow[b]{2}{*}{ Year } & \multicolumn{4}{|c|}{ Volume of sediment removed $\left(y d^{3}\right)$} \\
\hline & $\begin{array}{c}\text { Puyallup } \\
\text { River }\end{array}$ & $\begin{array}{l}\text { White } \\
\text { River }\end{array}$ & $\begin{array}{c}\text { Carbon } \\
\text { River }\end{array}$ & Total \\
\hline 1974 & 127,960 & 70,780 & 137,130 & 335,870 \\
\hline 1975 & 87,740 & 50,890 & 56,670 & 195,300 \\
\hline 1976 & 133,860 & 246,690 & 31,110 & 411,660 \\
\hline 1977 & 81,040 & 56,050 & 18,150 & 155,240 \\
\hline 1978 & 41,900 & 152,680 & 18,850 & 213,430 \\
\hline 1979 & 123,080 & 40,000 & 28,240 & 191,320 \\
\hline 1980 & 35,400 & 560 & 94,700 & 130,660 \\
\hline 1981 & 0 & 1,350 & 0 & 1,350 \\
\hline 1982 & 6,770 & 27,940 & 23,100 & 57,810 \\
\hline 1983 & 23,220 & 55,240 & 41,910 & 120,370 \\
\hline 1984 & 354,000 & 128,000 & $>40,000$ & $>522,000$ \\
\hline 1985 & 16,310 & 11,890 & 690 & ${ }^{1} 135,610$ \\
\hline 1986 & $>0$ & $>0$ & $>0$ & 92,130 \\
\hline 1987 & $>19,610$ & 11,060 & $>0$ & $1>115,670$ \\
\hline 1988 & 0 & 0 & 0 & 0 \\
\hline 1989 & $>0$ & 0 & $>0$ & $>0$ \\
\hline 1990 & $>0$ & 0 & 0 & $>0$ \\
\hline 1991 & $>36,000$ & 0 & 0 & $>36,000$ \\
\hline 1992 & 0 & 0 & 0 & 0 \\
\hline 1993 & 0 & 0 & 0 & 0 \\
\hline 1994 & $>10,000$ & 4,320 & 0 & $>14,320$ \\
\hline 1995 & $>9,100$ & 0 & 5,130 & $>14,230$ \\
\hline 1996 & 2,970 & 0 & 0 & 2,970 \\
\hline 1997 & 9,010 & 0 & 0 & 9,010 \\
\hline 1998 & $>0$ & 7,910 & 0 & $>7,910$ \\
\hline 1999 & 0 & 0 & 0 & 0 \\
\hline 2000 & 0 & 0 & 0 & 0 \\
\hline 2001 & 0 & 0 & 0 & 0 \\
\hline 2002 & 0 & 0 & 0 & 0 \\
\hline 2003 & 0 & 0 & 0 & 0 \\
\hline 2004 & 0 & 0 & 0 & 0 \\
\hline 2005 & 0 & 0 & 0 & 0 \\
\hline 2006 & 0 & 0 & 0 & 0 \\
\hline 2007 & 0 & 0 & 0 & 0 \\
\hline 2008 & 0 & 0 & 0 & 0 \\
\hline 2009 & 0 & 0 & 0 & 0 \\
\hline Total (rounded) & $>1,120,000$ & $>865,000$ & $>496,000$ & $>2,760,000$ \\
\hline
\end{tabular}

\footnotetext{
${ }^{1}$ Additional volume from unknown location.
}

Recurrence-interval peak discharges were determined by Prych (1988, tables A1-A3) for the Puyallup, White, and Carbon Rivers during Puyallup River peak discharges (table 2). Recurrence-interval peak discharges were also determined by Prych (1988) for the Puyallup, White, and Carbon Rivers during White River peak discharges (table 3).

Table 2. Recurrence-interval peak discharges in the study area during Puyallup River peak discharges, western Washington.

[Data from Prych, 1988. Abbreviation: $\mathrm{ft}^{3} / \mathrm{s}$, cubic foot per second]

\begin{tabular}{|c|c|c|c|c|}
\hline \multirow[t]{2}{*}{ River } & \multirow[t]{2}{*}{ Reach } & \multicolumn{3}{|c|}{$\begin{array}{l}\text { Recurrence-interval flow } \\
\left(\mathrm{ft}^{3} / \mathrm{s}\right)\end{array}$} \\
\hline & & 10-year & 50-year & 100 -year \\
\hline \multirow[t]{3}{*}{ Puyallup } & at mouth & 35,000 & 47,000 & 50,000 \\
\hline & $\begin{array}{l}\text { at confluence with } \\
\text { White River }\end{array}$ & 23,000 & 32,000 & 36,000 \\
\hline & $\begin{array}{l}\text { at confluence with } \\
\text { Carbon River }\end{array}$ & 11,000 & 15,400 & 17,200 \\
\hline White & at mouth & 12,000 & 15,000 & 14,000 \\
\hline \multirow[t]{2}{*}{ Carbon } & at mouth & 14,000 & 20,000 & 23,000 \\
\hline & $\begin{array}{l}\text { upstream of confluence } \\
\text { with South Prairie } \\
\text { Creek }\end{array}$ & 9,000 & 13,000 & 15,000 \\
\hline
\end{tabular}

Table 3. Recurrence-interval peak discharges in the study area during White River peak discharges, western Washington.

[Data from Prych, 1988. Abbreviation: $\mathrm{ft}^{3} / \mathrm{s}$, cubic foot per second]

\begin{tabular}{|c|c|c|c|c|}
\hline \multirow{2}{*}{ River } & \multirow{2}{*}{ Reach } & \multicolumn{3}{|c|}{$\begin{array}{l}\text { Recurrence-interval flow } \\
\qquad\left(\mathrm{ft}^{3} / \mathrm{s}\right)\end{array}$} \\
\hline & & 10-year & 50-year & 100-year \\
\hline \multirow[t]{3}{*}{ Puyallup } & at mouth & 25,000 & 34,000 & 37,000 \\
\hline & $\begin{array}{l}\text { at confluence with } \\
\text { White River }\end{array}$ & 23,000 & 32,000 & 36,000 \\
\hline & $\begin{array}{l}\text { at confluence with } \\
\text { Carbon River }\end{array}$ & 11,000 & 15,400 & 17,200 \\
\hline \multirow[t]{2}{*}{ White } & at mouth & 16,000 & 18,000 & 19,000 \\
\hline & at Lake Tapps return & 16,000 & 18,000 & 19,000 \\
\hline \multirow[t]{2}{*}{ Carbon } & at mouth & 14,000 & 20,000 & 23,000 \\
\hline & $\begin{array}{l}\text { upstream of confluence } \\
\text { with South Prairie } \\
\text { Creek }\end{array}$ & 9,000 & 13,000 & 15,000 \\
\hline
\end{tabular}


The Federal Emergency Management Agency (FEMA) published its most recent floodplain delineations for Pierce County, Washington, in 2007, including updates for the Puyallup, White, and Carbon Rivers in Pierce County (Federal Emergency Management Agency, 2007). The FEMA recurrence-interval peak discharges for the Puyallup, White, and Carbon Rivers are shown in table 4.

\section{Sediment from Mount Rainier}

By volume, Mount Rainier has the largest concentration of glaciers in the conterminous United States (Krimmel, 2002). In addition to producing melt water, these glaciers contribute substantial alluvial sediment to the downstream river network (Mills, 1976). Moreover, Mount Rainier is a dormant volcano that has had at least 11 pumice-producing eruptive periods during the Holocene (that is, during approximately the last 10,000 years; Hoblitt and others [1998]). Other volcanic processes are more frequent. For example, at least 60 lahars (large debris flows of volcanic origin) of various sizes have moved down the headwaters of Mount Rainier during the Holocene (Hoblitt and others, 1998). The largest of these, the Osceola Mudflow, occurred about 5,600 years ago from the northern flank of Mount Rainer, filled the White River to depths of $300 \mathrm{ft}$, covered more than $200 \mathrm{mi}^{2}$ of the Puget Lowland, and reached Puget Sound at Commencement Bay (Vallance and Scott, 1997). About 600 years ago, the Electron Mudflow, derived from a slope failure on the west flank of the mountain and not associated with an eruption, moved down the Puyallup River system and was more than $100 \mathrm{ft}$ thick near Electron and as much as $20 \mathrm{ft}$ thick near Orting (Scott and Vallance, 1995; Hoblitt and others, 1998).

Smaller debris flows that remain within the national park boundary occur more frequently and are spawned by heavy winter rainfall or during warm summer days when rapid melt from glaciers leads to hill-slope failures and associated debris flows (Walder and Driedger, 1995; Copeland, 2009). Many of these debris flows have initiated from exposed moraine sediment left by glaciers that have retreated since the end of the Little Ice Age, 150 years ago (Grove, 1988). Evidence suggests that debris-flow frequency in the past two decades has increased due to retreating glaciers and increased precipitation intensity (Paul Kennard, National Park Service, written commun., 2009). These debris flows, together with large floods, have led to increased sedimentation in proximal river reaches.

Comparing historical topographic maps of Mount Rainier National Park, Beason (2007) determined that the Carbon River between the park boundary and the source of the Carbon River aggraded $31 \mathrm{ft}$ on average between 1915 and 1971. Recently, Entrix (2008) determined that there was no significant change in bed elevation along the Carbon River near the park boundary since 1994; however,
Table 4. Recurrence-interval peak discharges for the Puyallup, White, and Carbon Rivers, western Washington.

[Data from Federal Emergency Management Agency, 2007. Abbreviation: $\mathrm{ft}^{3} / \mathrm{s}$, cubic foot per second]

\begin{tabular}{|c|c|c|c|c|}
\hline \multirow{2}{*}{ River } & \multirow{2}{*}{ Reach } & \multicolumn{3}{|c|}{$\begin{array}{l}\text { Recurrence-interval flow } \\
\left(\mathrm{ft}^{3} / \mathrm{s}\right)\end{array}$} \\
\hline & & 10-year & 50-year & 100-year \\
\hline \multirow[t]{3}{*}{ Puyallup } & at mouth & 41,000 & 46,000 & 48,000 \\
\hline & at confluence with & 27,500 & 38,600 & 43,500 \\
\hline & $\begin{array}{l}\text { at confluence with } \\
\text { Carbon River }\end{array}$ & 12,200 & 16,800 & 18,600 \\
\hline White & at mouth & 14,000 & 15,300 & 15,500 \\
\hline \multirow[t]{3}{*}{ Carbon } & at mouth & 18,600 & 26,800 & 30,400 \\
\hline & $\begin{array}{l}\text { upstream of } \\
\text { confluence with }\end{array}$ & 15,300 & 22,100 & 25,000 \\
\hline & $\begin{array}{l}\text { Voight Creek } \\
\text { upstream of } \\
\text { confluence with } \\
\text { South Prairie Creek }\end{array}$ & 8,700 & 12,700 & 14,500 \\
\hline
\end{tabular}

significant aggradation, ranging from $0.6 \mathrm{ft}$ to $4.8 \mathrm{ft}$ between 1994 to 2008, was documented by Entrix (2008) near the Ipsut Creek Campground, about 5 mi upstream of the park boundary and $4 \mathrm{mi}$ downstream of the glacier terminus. Trends between 1915 and 1971 on other river reaches in the park were moderate, with as much as $3.5 \mathrm{ft}$ of aggradation measured on Tahoma Creek and $-4.0 \mathrm{ft}$ change (net incision) on the White River. In the Nisqually River catchment, Beason (2007) also analyzed cross-section data to look for evidence for recent aggradation. Beason determined that the average rate of aggradation in the Nisqually River at Longmire was $0.6 \mathrm{in} / \mathrm{yr}$ between 1997 and 2006; the aggradation rate in the reach at Sunshine Point was 1.4 in/yr between 1997 and 2006. This increased aggradation rate in the Nisqually River was attributed to numerous debris flows from retreating glaciers (Copeland, 2009) and large floods that transported mobilized sediment downstream (Beason, 2007). It is not known and is beyond the scope of this study to determine how and when this Mount Rainier alluvial material will move into the Puget Lowland.

\section{Fluvial Geomorphic Investigations of the Puyallup River System}

Numerous researchers have investigated the fluvial geomorphology in the river network and the flux of sediment down the Puyallup, White, and Carbon Rivers. Sediment is transported in suspension, carried within the flowing water, or as bedload, transported along the bed by rolling, sliding, or saltating (hopping). 
Suspended-sediment and bedload transport were measured in the White River upstream of MMD from June 1974 to June 1976 (Nelson, 1979). Nelson developed a relation between daily suspended-sediment discharge and daily mean water discharge to calculate a suspended-sediment load of 430,000 short tons (tons) in the White River from June 1974 to June 1975 and 1,400,000 tons from June 1975 to June 1976. The bedload calculated by Nelson (1979) was about 4 percent of the suspended-sediment load. The bedload estimated by Nelson (1979) was 20,000 tons $\left(16,000 \mathrm{yd}^{3}\right.$ assuming a unit weight of sand and gravel of $93 \mathrm{lb} / \mathrm{ft}^{3}$, Brunner, 2008b) from June 1974 to June 1975 and 50,000 tons $\left(40,000 \mathrm{yd}^{3}\right)$ from June 1975 to June 1976.

Sediment transport and sedimentation between RM 5 and RM 30 along the White River were analyzed by Dunne (1986), which supported the Mullineaux (1970) geological inference that the coarse-bed material between RM 5 and RM 30 along the White River was derived from White River Canyon, downstream of MMD. Sediment transport in the White River prior to construction of MMD and the Lake Tapps diversion was reconstructed by Dunne (1986) to describe the influence of regulation on sediment transport in the river. He estimated discharge in the White River prior to construction of MMD from 1966 to 1973 and used these discharges along with sediment-transport curves (Nelson, 1979) to compute the sediment load from the drainage basin upstream of the dam. The 10-year (1966 to 1976) average annual suspended-sediment load estimated by Dunne (1986) would have been 500,000 tons ranging from 146,000 to $1,400,000$ tons with an estimate of annual bedload of about 20,000 tons $\left(16,000 \mathrm{yd}^{3}\right)$.

Cross sections throughout the Puyallup, White, and Carbon Rivers were measured by Prych (1988). Using these cross sections, Prych built a one-dimensional hydraulic model, computed the channel-conveyance capacity, and determined where the 100-year flood might compromise levees. Prych also compared cross-section elevations from data surveyed in 1977 to investigate geomorphic change. Differences of up to $2 \mathrm{ft}$ of aggradation and degradation were computed (Prych, 1988); however, the estimated accuracy of this method was between 1 and $2 \mathrm{ft}$. Some of the geomorphic change was attributed to gravel removal in the rivers between 1974 and 1985. Prych also documented the temporal trends of watersurface elevations at three USGS gaging stations on the Puyallup River and one USGS gaging station on the White River. Most analyses done by Prych (1988) were repeated in this study to assess any changes in the Puyallup River system since 1984.

Additional cross sections to extend the original study area of Prych (1988) and to increase cross-section density were measured by Sikonia (1990). Sikonia (1990) also collected additional data to build a one-dimensional sediment-transport model, which included bed-material, suspended-sediment, and bedload samples. Sikonia (1990) simulated sediment transport using Yang's (1973; 1984) equation, which computes total load (suspended and bedload) and includes separate equations for sand and gravel transport. Sikonia (1990) used his model to analyze the geomorphic response of the river to a few river-management scenarios including gravel-bar scalping and sediment traps. Sikonia (1990) concluded that gravel transport is small compared to silt and sand transport and is a localized process sensitive to local channel geometry. He also determined that there is considerable sand deposition in the lower White and lower Puyallup Rivers.

The feasibility of setback-levee projects along the Puyallup, White, and Carbon Rivers that would best reestablish dynamic channel-forming processes, recapture lost flood storage, and restore salmon habitat was analyzed by GeoEngineers (2008). Based on criteria established by GeoEngineers (2008) and Pierce County, the best sites for each river included the South Fork site on the Puyallup River just upstream of its confluence with the Carbon River, the Alward Road site on the Carbon River upstream of its confluence with South Prairie Creek, and the Countyline site on the White River near the Pierce-King County line.

Tetra Tech/Northwest Hydraulic Consultants (2009) conducted a lower Puyallup River flood-protection investigation to address flood-related issues along the Puyallup River from RM 0 to RM 8. The levees in this reach (as of 2007) were de-accredited by FEMA because the tops of the levees were no longer $3 \mathrm{ft}$ above the 100 -year water-surface elevation due to sediment accumulation (Lorin Reinelt, Pierce County, written commun., 2010). Tetra Tech/ Northwest Hydraulic Consultants (2009) investigated the "without-project" analysis in this reach to reduce the size of the recently mapped floodplain and determined that the bed material in the lower $6.87 \mathrm{mi}$ of the study area consisted of poorly graded sand with a median particle diameter of $0.35 \mathrm{~mm}$ (medium sand) and the bed material in the upper $3.32 \mathrm{mi}$ consisted of a bimodal distribution of poorly graded fine sand and poorly graded gravel. Sediment transport in the lower Puyallup River was simulated by Tetra Tech/ Northwest Hydraulic Consultants (2009) using LaursenCopeland's equation, which is a total-load formula developed for computing sediment transport of coarse silt to gravel. Their sediment-transport analysis showed little change in sediment load for the upper $2 \mathrm{mi}$ of the study area, indicating that transport of material through this reach occurs with little aggradation or degradation. Farther downstream, the load decreased, which indicated that deposition occurred in the lower reaches of the Puyallup River. Simulation of sediment transport for 50 years indicated that the bed would aggrade to a higher elevation, typically 1.5 to $3 \mathrm{ft}$ with a maximum increase of $5 \mathrm{ft}$ in some locations. The aggradation of sediment over the 50-year period would raise the 100 -year recurrence-interval discharge water-surface elevation by about $2 \mathrm{ft}$ at RM 2.27 on the Puyallup River. This analysis determined the likely locations of levee overtopping and breaching, the subsequent discharge over the levees, and the extent of flooding (Tetra Tech/Northwest Hydraulic Consultants, 2009). 
The Bureau of Reclamation (Bountry and Piety, 2009), in a series of studies (Huang, 2006; Bauer, 2009; Piety, 2009), analyzed the geomorphic and sediment effects following the setback of the Soldiers' Home levee on the Puyallup River from RM 21.3 to RM 22.5 near Orting. Their analysis included the Puyallup River from the Calistoga Bridge (RM 21.3) upstream to the Orville Road High Bridge (RM 25.2). A sediment-transport-capacity analysis using the one-dimensional model SRH-1D, river geometry data from 2003, and Sikonia's (1990) sediment data was performed by Huang (2006) to compare existing and future sediment-transport capacity to the incoming load. The results of this analysis indicated that the sediment-transport capacity before a setback-levee project is larger than the incoming load and that setting back the levee will reduce the sedimenttransport capacity in the setback reach by about 20 percent (Huang, 2006). However, the simulated sediment-transport capacity after a setback-levee project was larger than the incoming sediment load for discharges less than the 25-year recurrence-interval discharge (Huang, 2006). A gravelbar mobility study by Piety (2009) measured particle-size distributions of sediment on gravel bars, painted gravels, and resurveyed the painted sediment after high-discharge events to determine if painted particles were transported by the flow. During the survey period, high discharges occurred in January $2004\left(5,550 \mathrm{ft}^{3} / \mathrm{s}\right)$, January $2005\left(11,500 \mathrm{ft}^{3} / \mathrm{s}\right)$, and November $2006\left(21,500 \mathrm{ft}^{3} / \mathrm{s}\right)$. The size of the mobilized particles for the first two high flows with recurrence intervals of about 2 and 10 years, respectively, primarily were between the median size and 90 percent finer of the average substrate (Piety, 2009). After the November 2006 high-discharge event (with a recurrence interval of greater than 100 years), all of the gravel bars seemed to have been mobilized and no painted gravels were located (Piety, 2009). A comparison of channel cross-section elevations from several sources between 1974 and 2002 concluded that mean bed and thalweg elevations in the study reach did not change significantly (Bauer, 2009). Historical cross-section and elevation comparisons indicated that the channel has remained at nearly the same elevation from the 1930s or 1940s to 2002 (Bauer, 2009).

In 1948, when MMD was completed, the channel capacity in the White River (RM 0-9) was calculated to be $20,000 \mathrm{ft}^{3} / \mathrm{s}$, but channel capacity decreased steadily through time (U.S. Army Corps of Engineers, 2009). Recently, the USACE conducted a study to determine the channel capacities of the White and Puyallup Rivers, downstream of the confluence with the White River, using data collected by King County and the USGS in 2009 (U.S. Army Corps of Engineers, 2009). The study determined that the current (2009) channel capacity of the lower White River at Pacific, Wash., before flooding of undeveloped riparian zones was $5,000 \mathrm{ft}^{3} / \mathrm{s}$. Flooding of developed areas, however, does not occur until discharges reach $9,000 \mathrm{ft}^{3} / \mathrm{s}$. The U.S. Army Corps of Engineers (2009) determined that sediment aggradation and encroaching vegetation were primary factors decreasing channel capacity. The minimum channel capacity of the Puyallup River downstream of the confluence with the White River was 48,900 ft $3 / \mathrm{s}$ at RM 3.017 (U.S. Army Corps of Engineers, 2009).

In Mount Rainier National Park, aggradation along the Carbon and Nisqually Rivers has led to chronic flooding issues for historical structures and roadways in the park. The aggradation has been partly attributed to large volumes of sediment entering the fluvial systems due to glacial retreat and possible sedimentation problems that could persist in response to climate change (Entrix, 2008; 2009).

Herrera Environmental Consultants (2010) evaluated historical trends in sediment aggradation and degradation in the White River from about RM 4.44 to RM 10.60. The downstream end of this study was on the White River alluvial fan, from RM 4.44 to RM 7.30; since gravel-removal cessation, this reach aggraded 45,500 $\mathrm{yd}^{3} / \mathrm{yr}$ (Herrera Environmental Consultants, 2010). Between the $8^{\text {th }}$ Street Bridge (RM 4.99) and the A Street Bridge (RM 6.33) (fig. 2), the average rates of change in bed elevations were $2.8 \mathrm{in} / \mathrm{yr}$ from 2001 to 2007 and $5.3 \mathrm{in} / \mathrm{yr}$ from 2007 to 2009. Herrera Environmental Consultants (2010) also recorded slow rates of incision in the White River between the canyon and the alluvial fan, from RM 7.30 to RM 8.82 and aggradation and incision in the canyon from RM 8.82 to RM 10.60.

\section{Factors Affecting Flow Conveyance}

Flow conveyance is the discharge conveyed through a given channel reach for a given stage. The amount of flow that a channel can convey before overtopping is the channel-conveyance capacity. Modifications to the channel geometry or factors affecting the water velocity will modify how flow is conveyed through the channel.

Flow velocity is a function of channel slope and the resistance within the channel. An increase in the channel slope increases the flow conveyance, and an increase in resistance, or roughness of the channel, will decrease the flow conveyance. Factors affecting the flow resistance include the size and shape of bed material, type of bed forms (dunes, ripples, and bars), channel shape, meandering tendency of the channel, presence of suspended-sediment or bed-material transport, and structures like levees or bridges.

The channel size and shape are important factors in determining flow conveyance. An increase in bank elevation, through build-up of a levee for instance, increases the channel area and flow-conveyance capacity, or the flow that can be contained within the channel. A modification to the channel cross-sectional shape, by removing levees and setting them away from the main channel, would increase the channel area and flow-conveyance capacity. An increase in bed elevation, through sediment aggradation for instance, reduces the channel area and reduces the amount of flow conveyance in the channel. 
In alluvial rivers, such as those analyzed here, a linkage exists between the flow, sediment transport, and morphology. A modification of one of these properties initiates a feedback as the river responds to an altered state. For instance, an increase in the channel area reduces the flow velocity, which reduces the ability of the flow to transport sediment. A decrease in the sediment-transport capacity of the flow leads to sediment deposition and aggradation of the channel bed, which eventually decreases the channel area.

Additionally, modifications at one point in the river will affect the flow farther upstream. Alluvial rivers have predominantly subcritical flow (Jarrett, 1984; Grant, 1997; Magirl and others, 2009). Notably, for subcritical flow, the water-surface elevation, and in turn the wetted-channel area and flow velocity, at a given point in the river is determined by the conditions downstream.

\section{Physical Channel Measurements and Changes}

Channel cross sections and bed-material grain-size distributions were surveyed in the Puyallup, White, and Carbon Rivers during the summer and autumn of 2009. Channel cross-sections were compared to historical cross sections surveyed by Prych (1988) and the bed-material grain-size distributions were compared to historical data measured by Sikonia (1990).

\section{Cross-Section Survey}

The USGS surveyed 156 channel cross sections (92 for this study and 64 for a separately-funded project for the USACE) in the Puyallup, White, and Carbon Rivers during the summer of 2009, reoccupying cross sections measured by Prych (1988) and surveying additional cross sections to increase data density and extend data collection farther upstream (figs. A1-A12). The extent of the survey in the Puyallup River was from the mouth of the Puyallup River at Commencement Bay upstream past the Orville Road High Bridge (RMs 0-28.9). The White River was surveyed from its confluence with the Puyallup River to the 8th Street/ Stewart Road Bridge (RMs 0-4.9). King County Department of Natural Resources and Parks, Water and Land Resources Division coordinated the survey of additional cross sections in the White River from the 8th Street/Stewart Road Bridge upstream past the R Street Bridge into the White River Canyon (RMs 5-10.5) (Terry Butler, King County, written commun., 2009). The survey of the Carbon River extended from its confluence with the Puyallup River upstream past the Pioneer Way/State Route 162 Bridge (RMs 0-8.4). The cross section data surveyed by the USGS in 2009 are saved in a data file "2009 USGS CrossSections.csv" available for download at http://pubs.usgs.gov/sir/2010/5240/.
The cross-section naming convention follows the naming convention of Prych (1988), where the first letter refers to the river followed by a number that increments upstream (for example, P120 is a cross section on the Puyallup River). This study references three slightly different river-mile stationing systems: (1) based on a Pierce County river-mile centerline (used throughout this report; specific river-mile locations for individual cross sections measured in 2009 are listed in appendix C, table C1), (2) based on Pierce County river-mile posts (only shown in appendix A, figs. A1-A12), and (3) specific to the White River cross sections surveyed by King County (which only appear in these cross-section names). White River cross sections surveyed by King County in 2009 (Terry Butler, King County, written commun., 2009) begin with a King County designation followed by the river-mile location using the river-mileage system established by Northwest Hydraulic Consultants Inc. (2009), who surveyed the same cross sections in 2007 (for example, King Co. RM 6.077).

\section{Cross-Section Data-Collection Methods}

For the cross sections surveyed from the mouth of the Puyallup River upstream to its confluence with the White River, only below-water data were surveyed. These below-water data were tied into terrestrial Light Detection and Ranging (LiDAR) data collected in 2004 (Puget Sound LiDAR Consortium, 2004) to create complete channel cross sections. The above-water data measured by the $2004 \mathrm{LiDAR}$ possibly represented a different topographic surface than the 2009 below-water data because of the 5-year difference between data sources. However, because the above-water data mainly represented levees along the lower Puyallup River, the above-water data were not expected to have changed drastically between 2004 and 2009. The surveyed cross sections upstream of the confluence of the Puyallup and White Rivers included, where available, high-bank or levee points and below-water bathymetry. The channel surveys did not extend far out into the floodplain because the focus of the study was on channel capacity; however, the cross sections were surveyed to replicate the lateral extent measured in the original 1980s surveys (Prych, 1988).

Two methods that depended on site conditions were used to collect above-water topographic data upstream of the confluence of the Puyallup and White Rivers. For most of the cross sections, the above-water data were collected using a real-time kinematic network (RTN) global positioning system (GPS). The RTN GPS uses a network of base stations for differential corrections that are relayed to the GPS rover through a mobile-phone internet connection (Washington State Reference Network, 2010). At the beginning of each survey day, an RTN-GPS position was compared to the published coordinates of Washington State Department of Transportation (WSDOT) survey monument GP27167-93, last updated on May 6, 2008, located just upstream of USGS gaging 
station 12101500, Puyallup River at Puyallup (Washington State Department of Transportation, 2009). The estimated accuracy of positions obtained by the RTN-GPS survey to the WSDOT survey monument based on 104 measurements was about $0.1 \mathrm{ft}$ horizontally, with a standard deviation of about $0.03 \mathrm{ft}$, and $0.05 \mathrm{ft}$ vertically, with a standard deviation of about $0.05 \mathrm{ft}$. If an accurate RTN-GPS position could not be obtained in the field (typically due to tree cover), a total-station survey and reflective prism on a stadia rod were used to survey points along the cross section from a known location established by RTN GPS. Points surveyed using this method included total-station instrument error (less than $0.005 \mathrm{ft}$; Topcon, 2008) and RTN-GPS error ( $0.1 \mathrm{ft}$ horizontal and $0.05 \mathrm{ft}$ vertical) from an RTN-GPS established known location.

If the river was safe to wade, below-water data were collected using the RTN GPS. If the water was too deep or fast to wade, then below-water data were collected from a manned or tethered boat using an acoustic Doppler current profiler (ADCP) to measure the water depth, a differential global positioning system (dGPS) to track the ADCP's position, and the RTN GPS to measure the water-surface elevation. An ADCP uses acoustic energy to measure water velocity and depth (Simpson, 2002). The ADCP has four transducers arranged in a Janus configuration at 20 degrees from the vertical. Each transducer emits an acoustic ping that reflects off the river bed. The water depth is calculated from the acoustic ping time of return, compensating for the pitch and roll of the instrument and the transducer orientation. The dGPS was used to track the movement of the ADCP, as the boat traversed from one bank to the other, and subsequently the locations of the depth measurements. The RTN GPS was used to measure water-surface elevation and rectify ADCP-collected bathymetry into the geo-referenced coordinate system. At each cross section, the water-surface elevation was measured three times with the RTN GPS before and after the ADCP measurements to obtain an average water-surface elevation. Water depths were surveyed with the ADCP by starting near one bank and moving to the other bank of the river. These measurement passes were repeated anywhere from two to eight times depending on the site conditions.

The geo-referenced positions of each point collected with the ADCP, RTN GPS, and total-station surveys were imported into a geographic information system (GIS). For each cross section, the combined data were snapped to a straight line and formatted in a two-dimensional frame of reference (station/ elevation) consistent with cross-section geometry data used in one-dimensional hydraulic modeling (Ackerman, 2009). The station for each elevation point is the distance measured from the left-most data point when viewing the cross section looking downstream. The below-water part of the crosssection data derived from the ADCP data were filtered and subsampled to eliminate redundant points (some raw cross sections initially contained more than 2,000 below-water depth measurements).
A few cross-section locations did not line up with the cross sections reported by Prych (1988). During the field survey, these cross sections were moved upstream or downstream of the original location to improve data quality, address safety concerns, or to avoid objects obstructing the survey. These cross sections were not used in the comparative (Prych, 1988) analysis, but were used to construct the hydraulic model. The positional error of a cross section in the 2009 survey relative to the 1984 survey depends on the slope of the river and the basin at a particular cross section, and is estimated to be about $0.5 \mathrm{ft}$ vertically.

\section{Channel-Change Analysis}

The channel cross sections surveyed in 2009 were compared to cross sections measured by Prych (1988) in 1984 by computing average channel elevations of each cross section to determine geomorphic trends in the Puyallup, White, and Carbon Rivers. The changes in average channel elevations were then used to compute the volume of bed change within each river.

\section{Comparison of 1984 and 2009 Channel Surveys}

Cross sections developed by Prych (1988), originally reported relative to the National Geodetic Vertical Datum of 1929 (NGVD 29), were converted to the North American Vertical Datum of 1988 (NAVD 88) based on the approximate location of the center of each cross section using the VERTCON computer program (version 2.1; National Geodetic Survey, 2003). Replicating the analytical approach of Prych (1988), the average elevation of each cross section was calculated by integrating the surveyed elevation data between selected points on the left and right banks and dividing the integral by the cross-sectional width (fig. 3). Bank points were selected to match up as closely as possible between the two surveys, without including an extensive floodplain within the bank points for one cross section and not the other. Differences in average cross-section elevations from the 1984 survey and the 2009 survey were calculated to determine the channel change at specific locations.

The volume of bed change between 1984 and 2009 was computed using the average end-area volume computation method (Breed, 1916). The change in cross-sectional area was determined by multiplying the change in average cross-section elevation by the width between 2009 bank points. The change in cross-sectional area in adjacent cross sections was averaged and then multiplied by the distance between the cross sections to compute a volume of bed change between 1984 and 2009. The total volume of bed change in each river was then computed by summing the volumes of bed change within the river. 


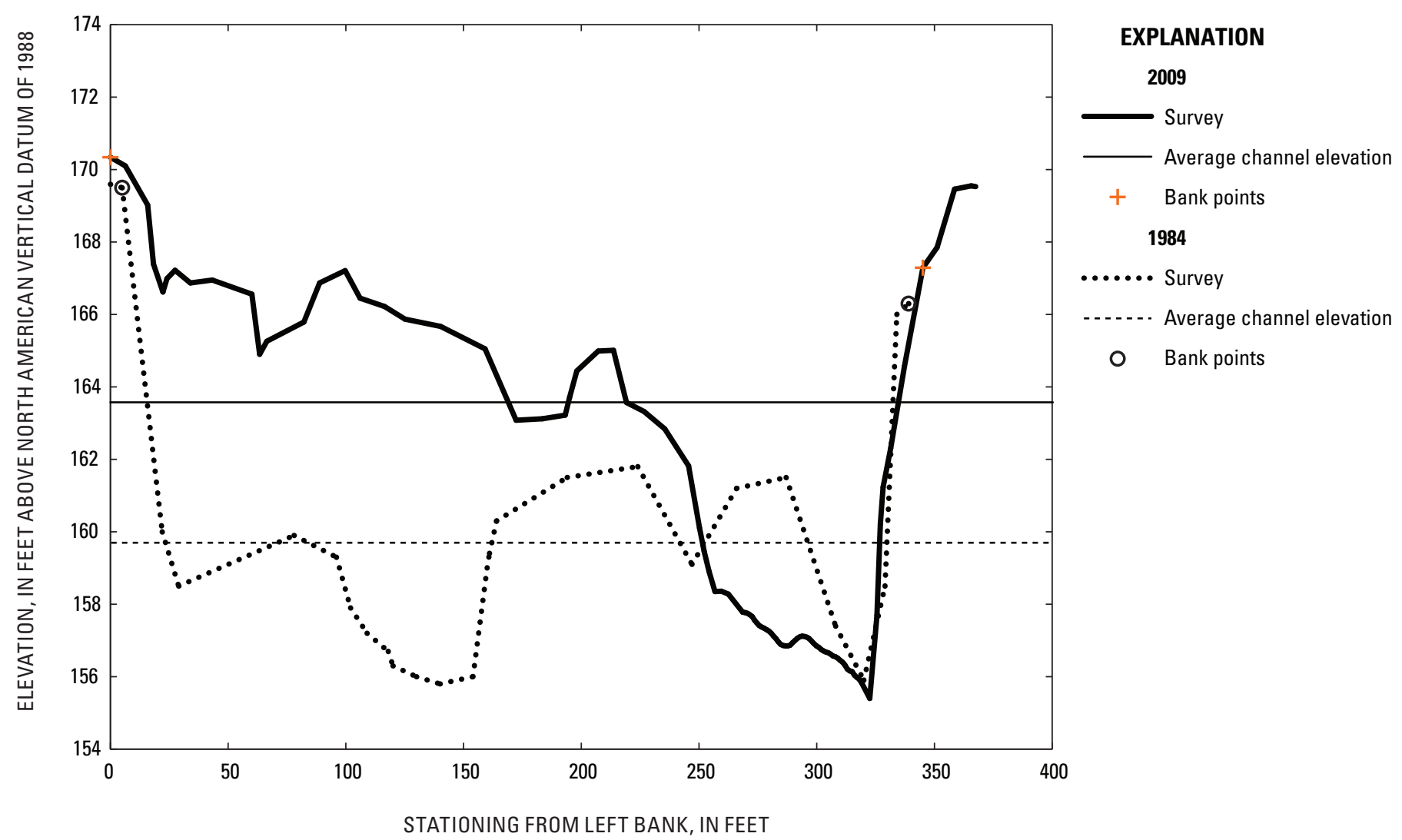

Figure 3. Comparison of average channel elevation at cross section P120, Puyallup River, Washington between 1984 and 2009. Location of cross section is shown in figure A6.

\section{Source of Error in Comparison}

The magnitude of the probable error in the computed change in the average cross-section elevations between 1984 and 2009 is related to errors in the survey data and in computing the average elevations. The probable error in elevations obtained from the 1984 survey is $0.2 \mathrm{ft}$ (Prych, 1988). The probable error in elevations obtained from the 2009 survey is due to the error in the actual instrument, the variability of the ground and where the survey rod is placed, and the error induced in snapping points to a line, the total is estimated to be about $0.2 \mathrm{ft}$. The positional errors of a cross section in the 2009 survey relative to the 1984 survey depend on the slope of the river and the basin at a particular cross section, but are estimated to be about $0.5 \mathrm{ft}$ vertically. The density of survey points is much greater in the 2009 survey than in the 1984 survey, and the error from computing the average elevation based on several discrete points is estimated to be about $0.2 \mathrm{ft}$. The magnitude of the probable error in the computed change in the average cross-section elevations is approximated by the square root of the sum of squares of all individual errors (Dally and others, 1984). Therefore, the magnitude of the probable error in the difference between the 1984 and 2009 average cross-section elevations is estimated to be about $0.6 \mathrm{ft}$. Due to the uncertainty of individual error estimates, the accuracy in the change analysis is about $1 \mathrm{ft}$. When interpreting comparative changes in average cross-section elevations between 1984 (Prych, 1988) and 2009, emphasis should be placed on trends along a river segment when calculated channel change is greater than about $2 \mathrm{ft}$. An increase or decrease in average channel elevation at an individual cross section could be due to where the channel was surveyed with respect to a riffle or other geomorphic feature. Significant change (greater than about $2 \mathrm{ft}$ ) of three or more adjacent cross sections would indicate that aggradation or incision has occurred in a particular reach. 


\section{Channel-Elevation Change between 1984 and 2009}

The geomorphic trends of aggradation and incision between 1984 and 2009 were analyzed for each of the three rivers in the study.

\section{Puyallup River}

Reaches showing significant aggradation from 1984 to 2009 in the Puyallup River (ig. 4) include: just downstream of the confluence with the White River (RM 9.1 to RM 10.1), with a change in average channel elevation of about 3.5 $\mathrm{ft}$; along the middle Puyallup River from RM 13.4 to RM 14.2, with an average change of about $2 \mathrm{ft}$; upstream of the confluence with the Carbon River to the Calistoga Bridge (RM 18.4 to RM 21.5), with an average change of about $3 \mathrm{ft}$; and upstream of the Calistoga Bridge to downstream of the USGS gaging station 12093500, Puyallup River near Orting (RM 22.6 to RM 24.7), with an average change of about $4 \mathrm{ft}$. Aggradation in reaches downstream of the Carbon River confluence appears to be due to coarse-sediment deposition. Coarse-sediment deposition is a major factor upstream of the Carbon River confluence, but farther upstream the river spreads out and is no longer as confined by levees. A river confined by levees deepens its channel and when levees are removed, the river spreads out over its floodplain and fills in the over-deepened area of its channel. Little change (less than $2 \mathrm{ft}$ in average channel elevation) has occurred in the lowest reaches of the Puyallup River (RM 0 to RM 8.8) and in smaller reaches not defined above. A simulation of sediment-transport for 50 years in the lower Puyallup River indicated that the bed would aggrade to a higher elevation, typically $1.5-3 \mathrm{ft}$ with a maximum increase of $5 \mathrm{ft}$ in some locations (Tetra Tech/Northwest Hydraulic Consultants, 2009). Within the past 25 years (1984-2009) the bed in this reach has aggraded by about $1 \mathrm{ft}$ with a maximum rise of about 2 ft. Cross sections described by Prych (1988) did not extend upstream of about RM 26 on the Puyallup River. The reaches that did not show much change (mainly downstream of the confluence with the White River) are capable of transporting sediment without allowing significant deposition.

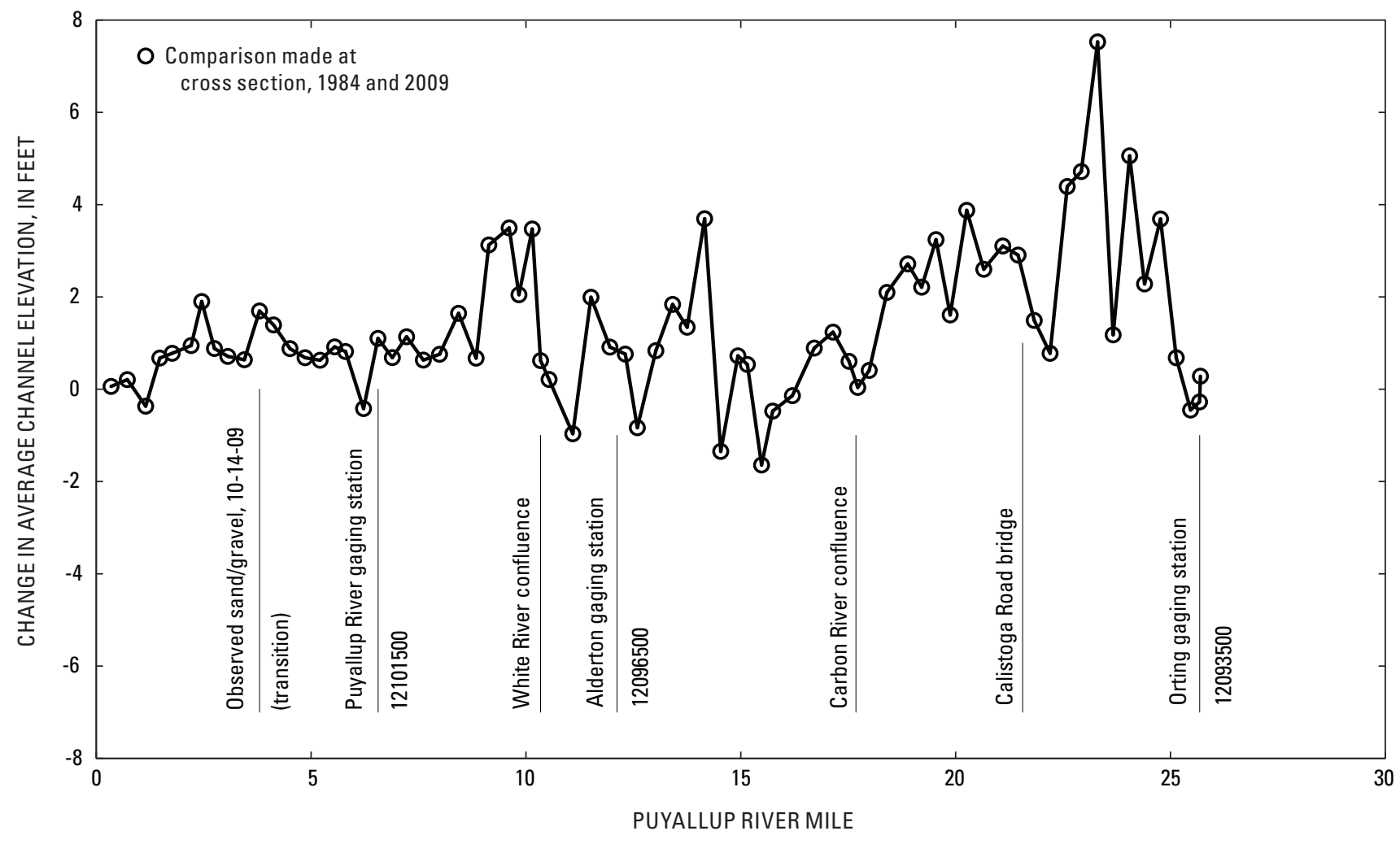

Figure 4. Change in average channel elevation between 1984 and 2009 in the Puyallup River, western Washington. 
At USGS gaging station 12101500, Puyallup River at Puyallup, the average channel elevation increased by $1.1 \mathrm{ft}$ between 1984 and 2009 with a similar value of aggradation downstream of the gaging station. The average channel elevation increased by about $0.9 \mathrm{ft}$ between 1984 and 2009 at USGS gaging station 12096500, Puyallup River at Alderton, with aggradation as much as $2.0 \mathrm{ft}$ just downstream of the gaging station. At USGS gaging station 12093500, Puyallup River near Orting, the average channel elevation decreased by $0.3 \mathrm{ft}$ between 1984 and 2009 with aggradation as much as 2.0-7.5 $\mathrm{ft}$ downstream of the gaging station.

The change in bed volume in the Puyallup River between 1984 and 2009 (fig. 5) shows a similar trend as the change in channel elevation. The largest volume of deposited sediment was in the upper Puyallup River with a 25-year (1984-2009) total net volume of deposition between the confluence with the Carbon River and the Calistoga Bridge (RM 17.7-21.5) of approximately 429,000 $\mathrm{yd}^{3}, 17,200 \mathrm{yd}^{3} / \mathrm{yr}$, or 4,500 $\mathrm{yd}^{3} / \mathrm{yr} /$ RM; and between the Calistoga Bridge and the USGS gaging station 12093500, Puyallup River near Orting, (RM 21.5-25.7) of approximately $907,000 \mathrm{yd}^{3}, 36,300 \mathrm{yd}^{3} / \mathrm{yr}$, or 8,600 $\mathrm{yd}^{3} /$ $\mathrm{yr} / \mathrm{RM}$. The reach with the largest volume of deposition (RM 21.5-25.7) in the Puyallup River corresponded to the setback levees, the 1998 Ford-Hatten-Filbin setback levee between RM 23.4-25.0 and the 2006 Soldiers' Home setback levee between RM 21.5-22.4. It seems that the setback levees provided an area where the river can spread out and deposit sediment. The 25-year total net volume of deposition in the Puyallup River between RM 0.3-25.7 was approximately $2,290,000 \mathrm{yd}^{3}, 91,500 \mathrm{yd}^{3} / \mathrm{yr}$, or 3,600 $\mathrm{yd}^{3} / \mathrm{yr} / \mathrm{RM}$.

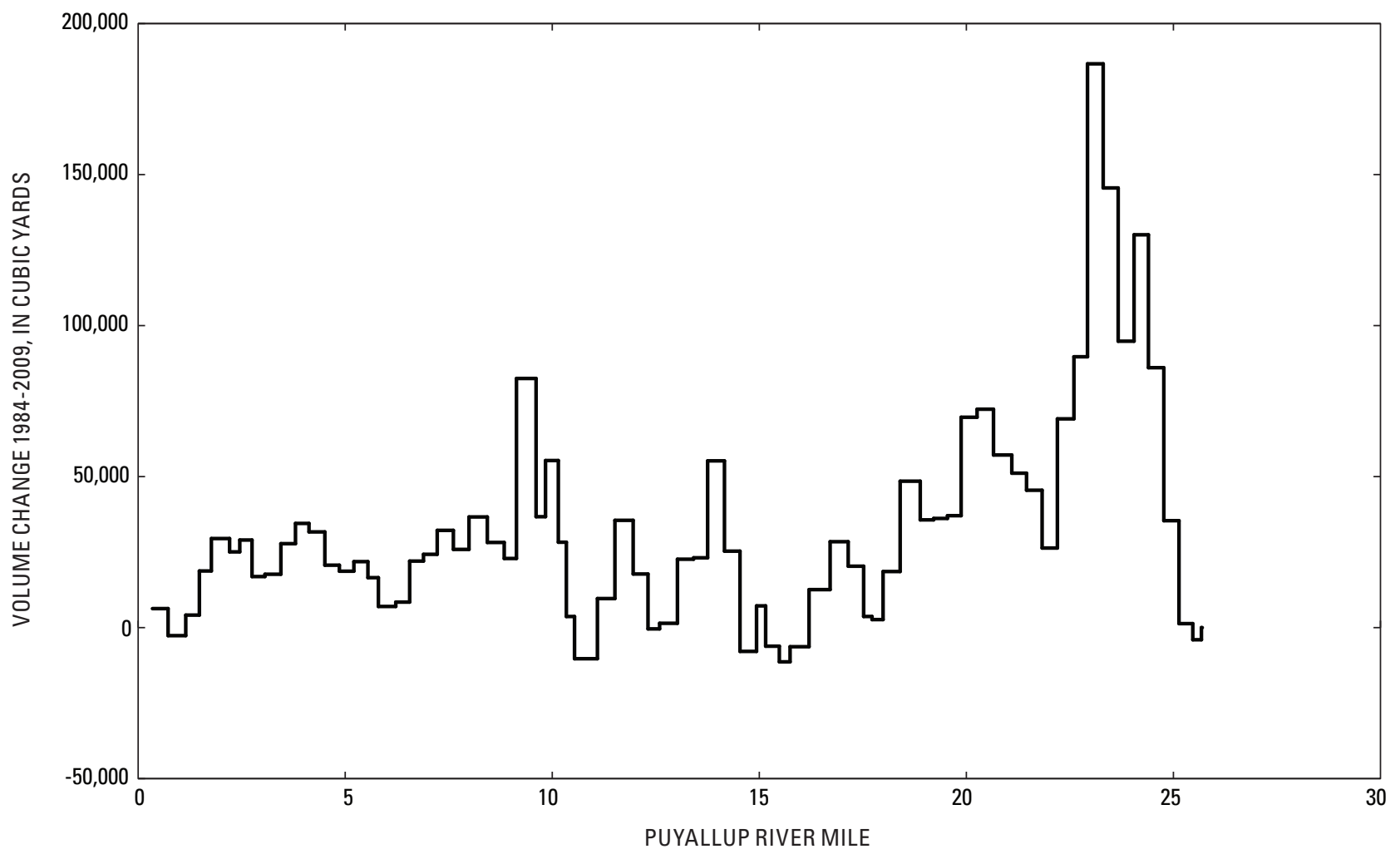

Figure 5. Change in bed volume between 1984 and 2009 in the Puyallup River, western Washington. 


\section{White River}

Change in the average cross-section elevations in the White River suggests aggradation has mainly occurred in one reach with little or variable change everywhere else. The reach showing significant aggradation from 1984 to 2009 in the White River is from the Lake Tapps return to just downstream of the R Street Bridge (RM 4 to RM 7.2), with changes in average channel elevation ranging from 2 to $6.5 \mathrm{ft}$ (fig. 6). Significant gravel removal occurred in this reach just prior to the channel survey by Prych (1988), and this reach seems to have filled in with sediment. Little change (less than $2 \mathrm{ft}$ in average channel elevation) has occurred downstream of the Lake Tapps return to the mouth of the White River (RM 0 to RM 4) and from just downstream of the R Street Bridge upstream for a short reach (RM 7.4 to RM 9). Upstream of the $\mathrm{R}$ Street Bridge, the river has more capacity for transporting sediment, which limits channel change. Variable change, where the change in average channel elevation jumped from about positive $2 \mathrm{ft}$ to negative $2 \mathrm{ft}$ within $0.5 \mathrm{mi}$, has occurred upstream of RM 9 to the upstream extent of this analysis at RM 10.5. The change in the average cross-section elevations from 1984 to 2009 in the White River agrees with the changes reported by Herrera Environmental Consultants (2010).

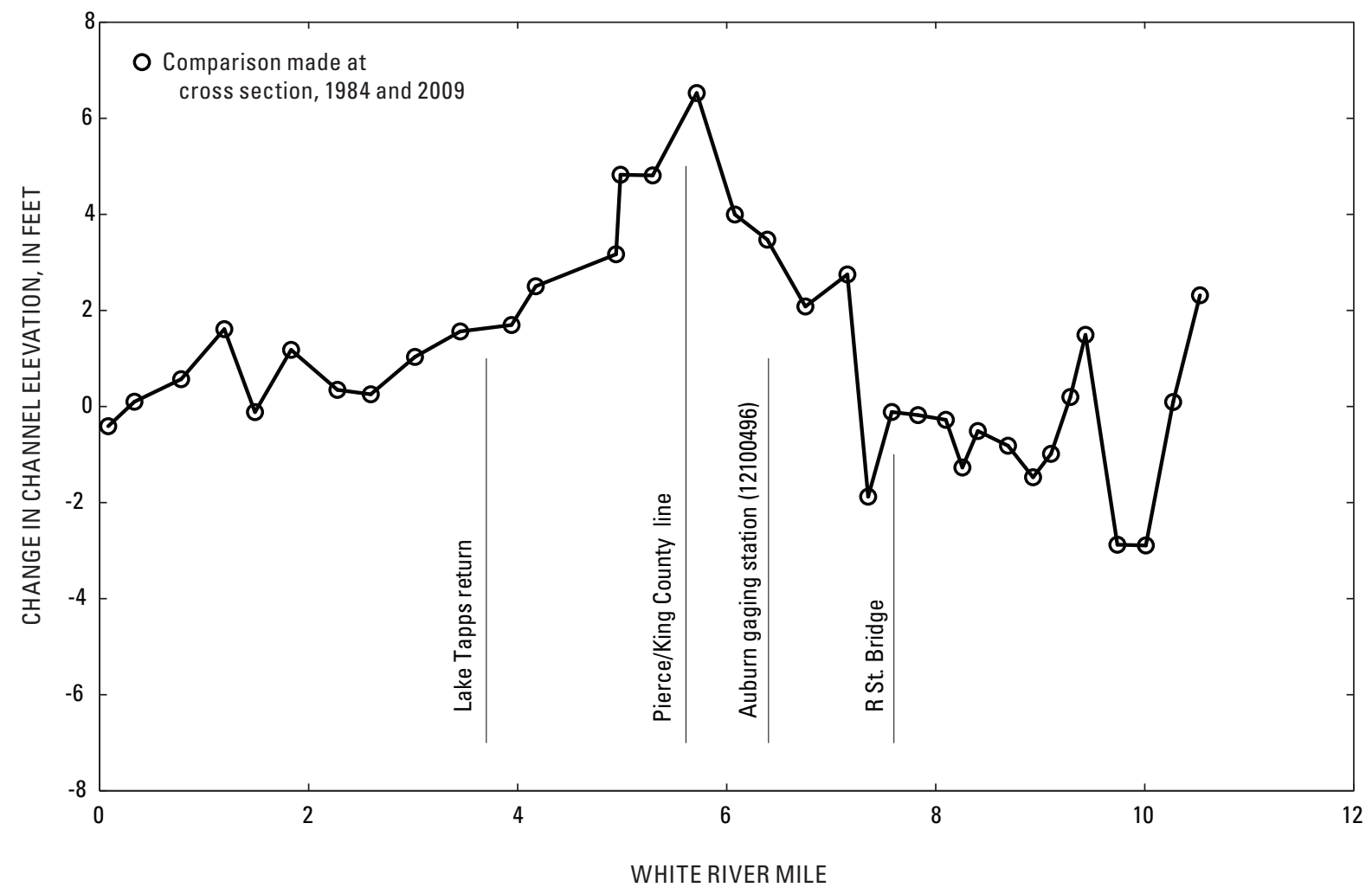

Figure 6. Change in average channel elevation between 1984 and 2009 in the White River, western Washington. 
The calculated change in average channel elevations near USGS gaging station 12100496, White River near Auburn, showed aggradation of $3.5 \mathrm{ft}$ between 1984 and 2009. The value of aggradation downstream of the gaging station was even more, increasing as much as $6.5 \mathrm{ft}, 0.5 \mathrm{mi}$ downstream.

The change in bed volume in the White River between 1984 and 2009 (fig. 7) shows a similar trend as the change in channel elevation. The largest 25-year (1984-2009) total net volume of deposited sediment in the White River was between the Lake Tapps return and the R Street Bridge (RM 3.9-7.6) of approximately $547,000 \mathrm{yd}^{3}, 21,900 \mathrm{yd}^{3} / \mathrm{yr}$, or $5,900 \mathrm{yd}^{3} /$ yr/RM. This reach of the White River (RM 3.9-7.6) has accumulated large quantities of sediment in the past (Dunne, 1986) and has been the focus of gravel removal operations. The 25-year (1984-2009) total net volume of deposition in the White River between RM 0.1 and 10.5 was approximately $535,000 \mathrm{yd}^{3}, 21,400 \mathrm{yd}^{3} / \mathrm{yr}$, or 2,100 $\mathrm{yd}^{3} / \mathrm{yr} / \mathrm{RM}$.

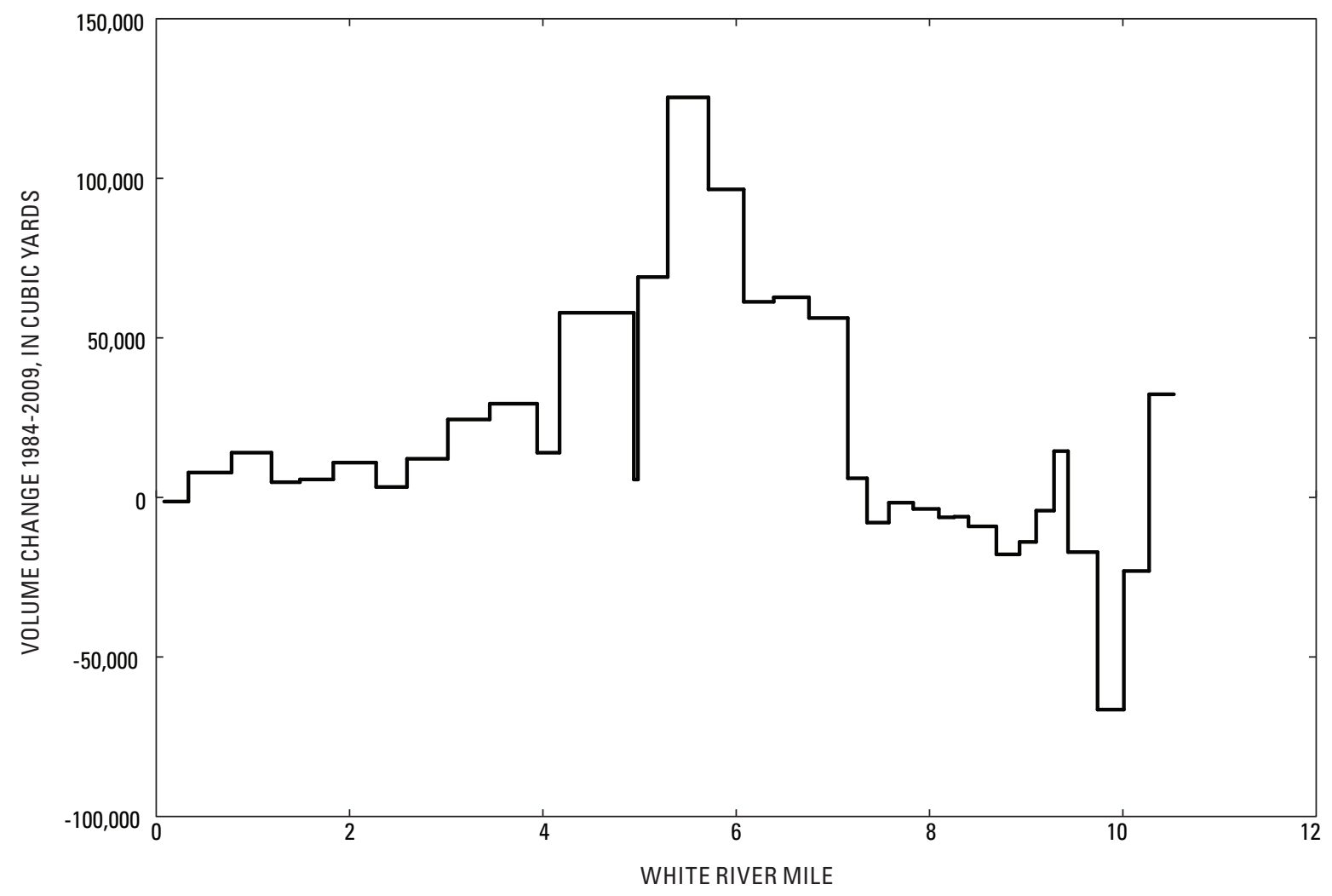

Figure 7. Change in bed volume between 1984 and 2009 in the White River, western Washington. 


\section{Carbon River}

Change in the average cross-section elevations in the Carbon River (fig. 8) suggests little or variable change between 1984 and 2009. Little change (less than $2 \mathrm{ft}$ in average channel elevation) occurred in the lowest reaches of the Carbon River (RM 0 to RM 3.1) and variable change, with a change in average channel elevation of about $2 \mathrm{ft}$ for about $0.3 \mathrm{mi}$, occurred upstream of the South Prairie Creek tributary to the upstream extent of this study (RM 5.6 to RM 5.9). In the lowest $3 \mathrm{mi}$ of the Carbon River, the channel is constricted by levees and a high bluff along the right bank, which seems to create a channel geometry that allows most sediment entering the reach to be transported through to the Puyallup River.

Possible survey errors in six consecutive cross sections (C18, C19, C22, C24, C26, and C28), located in the reach downstream of Voight Creek to just downstream of
South Prairie Creek (RM 3.5 to RM 5.4), prevented direct comparison between 1984 and 2009 channel cross sections. Within this problematic reach, the elevation along the top of the left-bank levee surveyed in 1984 and 2009 differed between 2.7 and $7.7 \mathrm{ft}$. In all other cross sections surveyed for this study, where unmodified levees were unambiguously identified in both the 1984 and 2009 cross sections, the difference between top-of-levee elevations in 1984 and 2009 was consistently within $1 \mathrm{ft}$. One possible explanation for the discrepancy in levee elevation within the problematic reach is that the left levee had been built up in the intervening years. However, the left-bank levee downstream of C19 had not been built up between 1984 and 2009 where only minor repairs to the levee have occurred with no appreciable change to the top of the levee elevation (Tony Fantello, Pierce County, written commun., 2010). Furthermore, the left bank upstream of

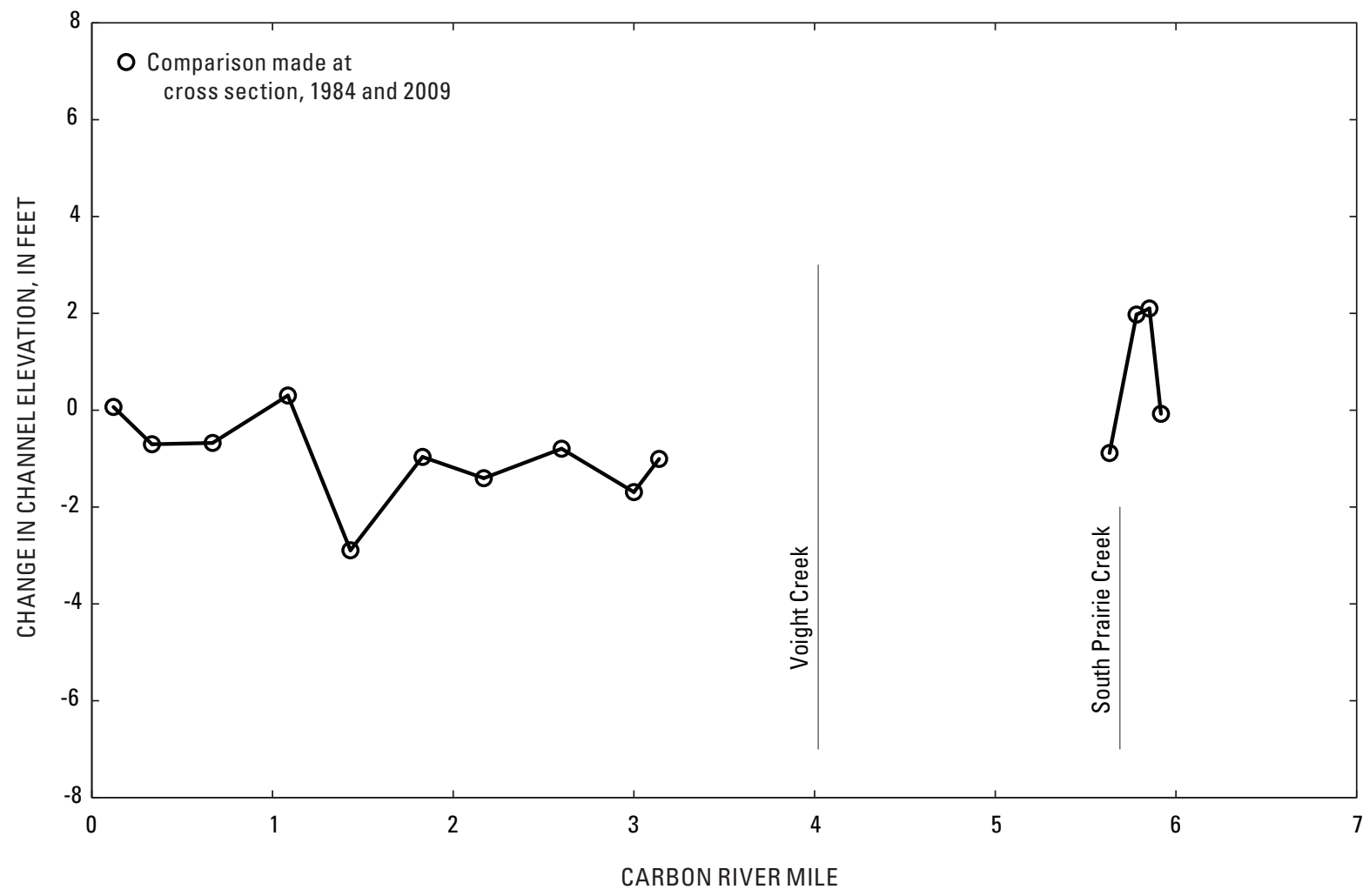

Figure 8. Change in average channel elevation between 1984 and 2009 in the Carbon River, western Washington. 
C22 was a railroad bed in 1984 and converted to a bike and pedestrian pathway prior to 2009. At most, 3 in. of gravel and 3 in. of asphalt were added to the top of this railroad bed (Grant Griffin, Pierce County, written commun., 2010). Moreover, the 2009 survey data and processing methods were quality assured and field-checked for accuracy. Ultimately, it was concluded that the most likely source of error resided in the elevation control established for the 1984 cross sections. As a result of this possible error source, cross-section aggradation for this problematic reach of the Carbon River could not be determined.

The change in bed volume in the Carbon River between 1984 and 2009 (fig. 9) shows a similar trend as the change in channel elevation. The 25-year (1984-2009) total net volume of deposition (negative means incision) in the Carbon River between RM 0.1-3.1 and 5.6-5.9 was approximately $-150,000 \mathrm{yd}^{3},-6,000 \mathrm{yd}^{3} / \mathrm{yr}$, or $-1,800 \mathrm{yd}^{3} / \mathrm{yr} / \mathrm{RM}$.

\section{Overall Channel Changes}

The change in average channel elevation between 1984 and 2009 in the Puyallup, White, and Carbon Rivers, when viewed together show the complexity of the sedimentation trends within the study area (fig. 10). Where the Puyallup and White Rivers leave their canyons, a significant change in average channel elevation has occurred corresponding to sediment deposition. The canyons are transport reaches and convey sediment from the upper drainage basin to the lowland rivers. The middle Puyallup River supplies coarse sediment into the lower Puyallup River which deposits just downstream of the confluence with the White River where the capacity to move this coarse material has decreased. Based on the reliable data for the Carbon River, it appears that the sediment that enters the lower reaches of the Carbon River is transported downstream without aggrading the channel.

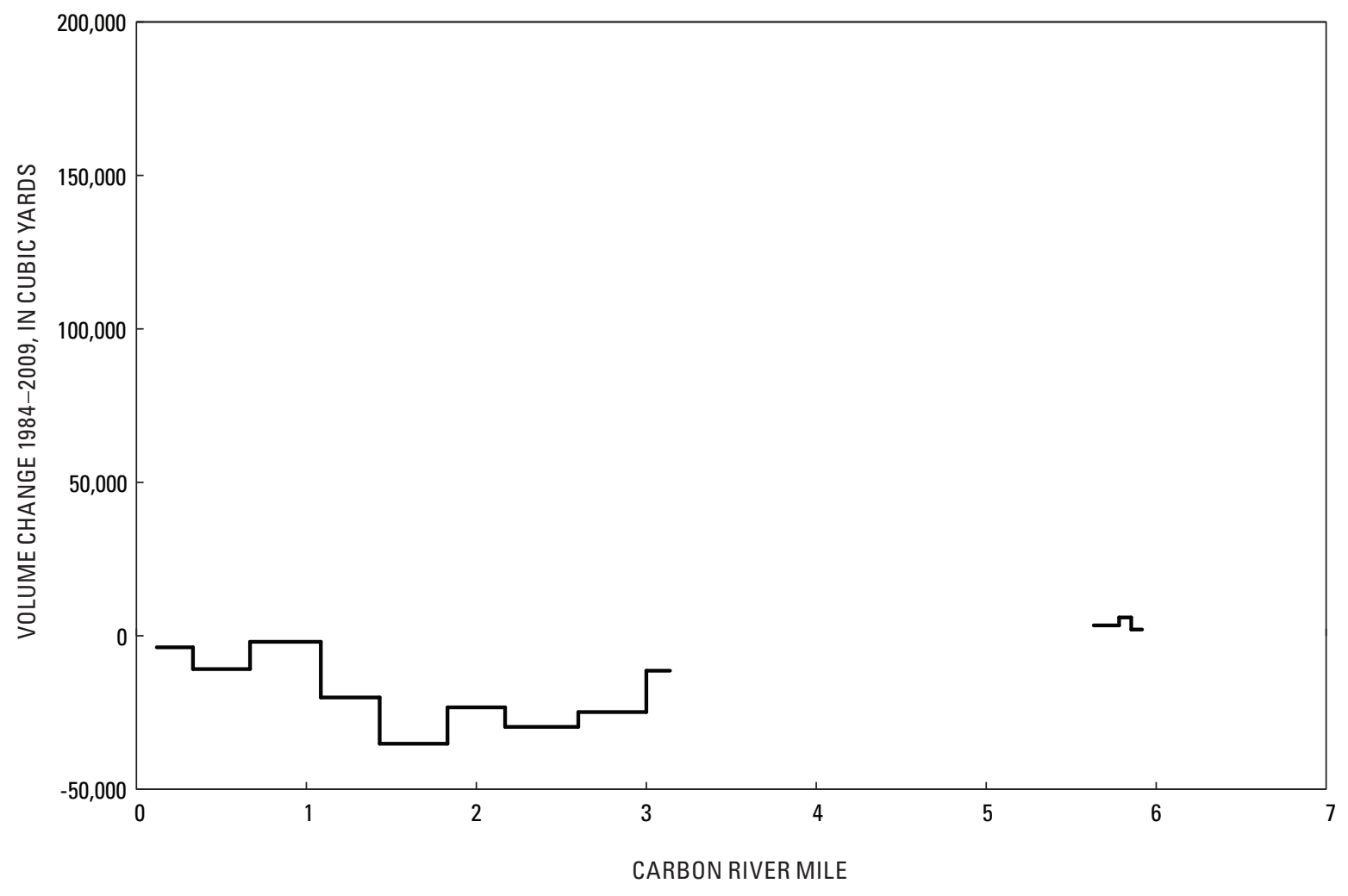

Figure 9. Change in bed volume between 1984 and 2009 in the Carbon River, western Washington. 


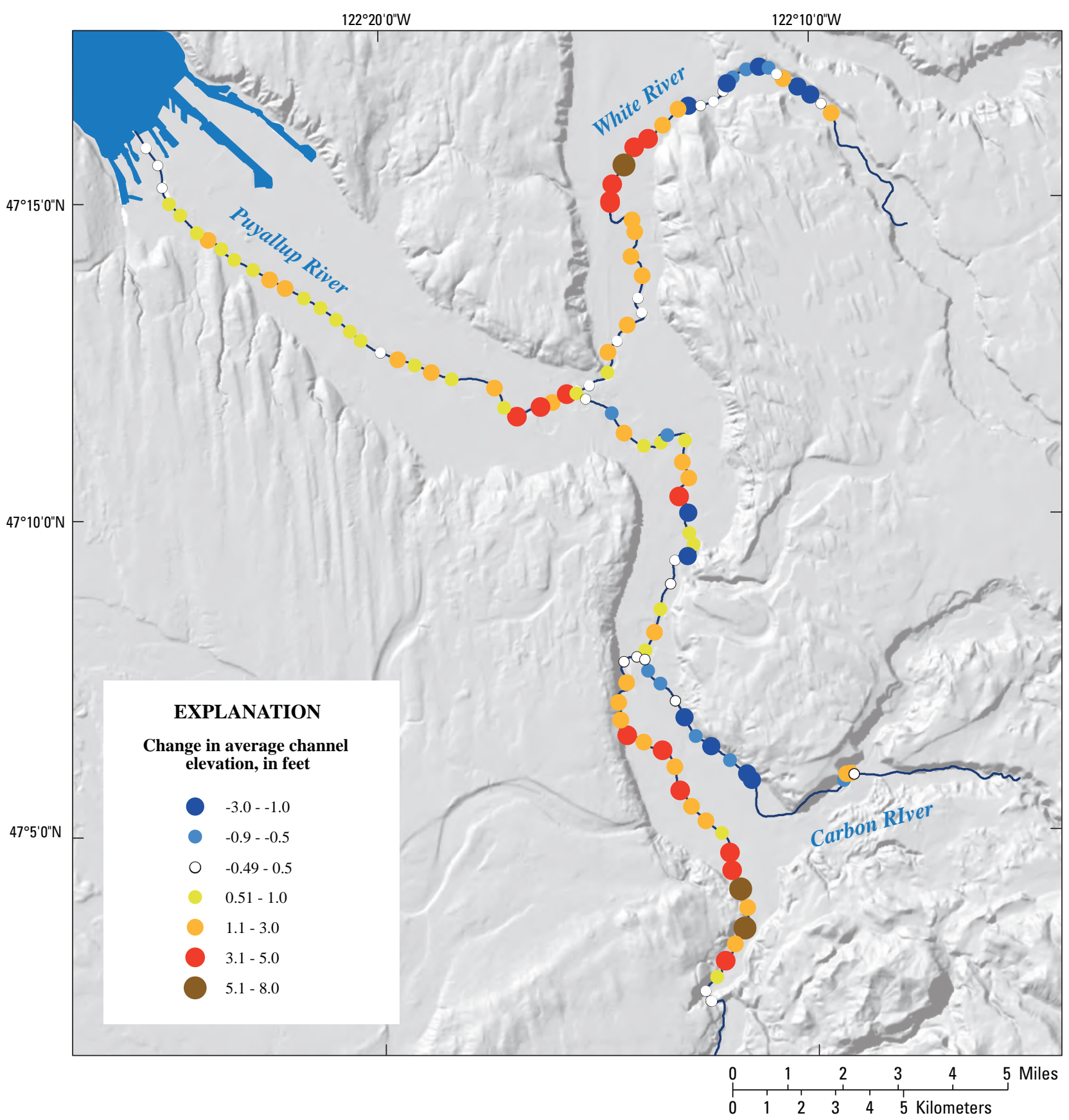

Figure 10. Change in average channel elevation between 1984 and 2009 in the Puyallup, White, and Carbon Rivers, western Washington. 


\section{Bed-Material Grain-Size Survey}

In October and November 2009, the USGS measured bed-material grain size at 130 points along 30 cross sections in the study area, 45 points along 13 cross sections for the USACE and 85 points along 17 cross sections as part of this study. Depending on the characteristics of a cross section, from one to five measurements were made along each section. Measurement cross sections were selected at critical hydraulic locations (such as near a confluence of two rivers) and at locations near potential river-management sites. The bed-material grain-size distribution data measured by the USGS in 2009 are saved in a data file "2009_USGS BedMaterialGrainSizeDistributions.csv" available for download at http://pubs.usgs.gov/sir/2010/5240/.

\section{Bed-Material Grain-Size Data-Collection Methods}

Samples of fine-grained material from subaqueous riverbed sections of the lower Puyallup and White Rivers were measured by sampling with a pipe dredge and sieving the sample. Grain size on the surface of exposed gravel bars was determined using the Wolman point-count method (Wolman, 1954). The subsurface grain size of exposed bars was determined using a combination of the Wolman method and sample sieving.

For each sample, the frequency of particles within specific size classes was determined and the cumulative percent finer for specific size classes was calculated (table 5). A simple metric used for comparing bed-material size distributions is the grain sizes at which 50 percent of the material in the distribution is finer than, referred to as the D50. In bed-material size distributions with a strong bimodal tendency, the D50 grain size for particles greater than $2 \mathrm{~mm}$ distinguishes changes in coarse-sediment size from changes in the proportion of fine to coarse sediment. The percentage of material finer than $2 \mathrm{~mm}$ distinguishes the proportion of fine to coarse sediment.

\section{Riverbed Sampling of Fine-Grained Sediment}

When the bed material was predominantly sand-sized, samples were collected from a boat with a 3- by 3-in. box dredge (fig. 11). The samples collected using this technique were located at cross sections P2, P13, P26, W41, W51, and W59 (figs. A1-A12; table C1). The fine-grained sediment samples were sent to the USGS Cascades Volcano Observatory (CVO) sediment lab in Vancouver, Wash., for sieve analysis.
Table 5. Size classes for sediment.

[Abbreviation: mm, millimeter]

\begin{tabular}{llc}
\hline Group name & \multicolumn{1}{c}{ Grain class } & $\begin{array}{c}\text { Size range } \\
(\mathbf{m m})\end{array}$ \\
\hline Sand & Coarse silt & $0.032-0.0624$ \\
& Very fine sand & $0.063-0.124$ \\
& Fine sand & $0.125-0.24$ \\
& Medium sand & $0.25-0.4$ \\
& Coarse sand & $0.5-0.9$ \\
Gravel & Very coarse sand & $1-1.9$ \\
& Very fine gravel & $2-3.9$ \\
& Fine gravel & $4-7.9$ \\
& Medium gravel & $8-15.9$ \\
& Coarse gravel & $16-31.9$ \\
Cobbles & Very coarse gravel & $32-63.9$ \\
& Small cobbles & $64-127.9$ \\
& Large cobbles & $128-255.9$ \\
& Small boulders & $256-511.9$ \\
& Medium boulders & $512-1,023.9$ \\
\hline
\end{tabular}

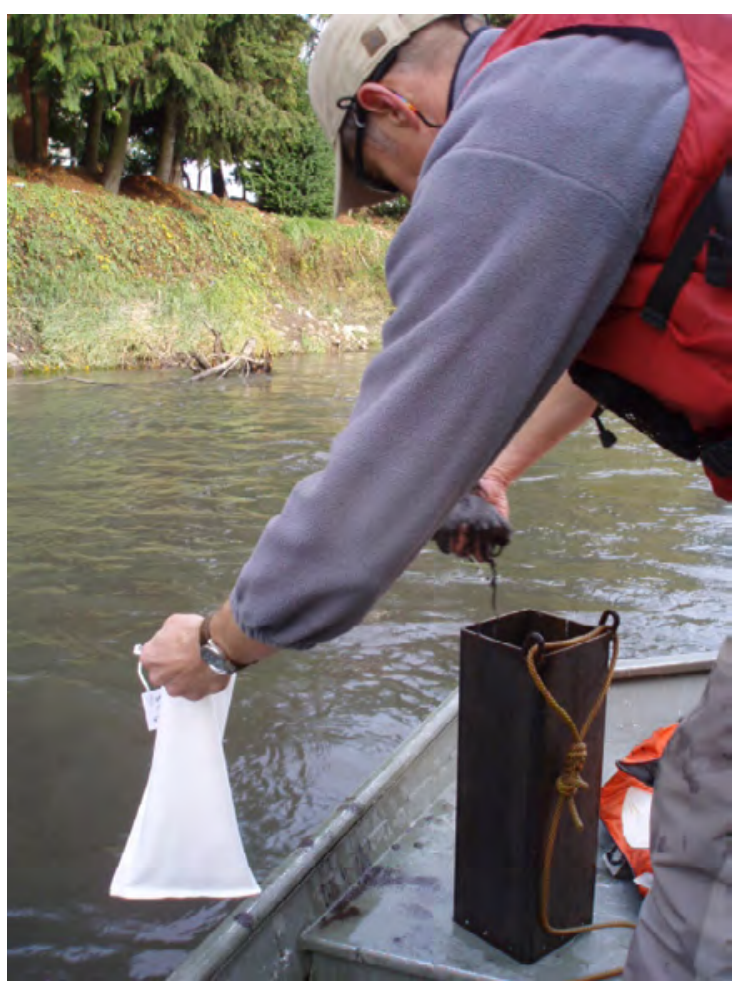

Figure 11. Method used to transfer fine-grained sediment from the dredge to a sediment bag at cross section W51, White River, western Washington, November 4, 2009. Photograph taken by Jonathan Czuba, U.S. Geological Survey. 
Eight dredged riverbed samples contained coarse-gravel or cobble particles in an otherwise sand-dominant matrix including one sample from P26, two samples from P30, three samples from P42, and the subsurface samples from P62 and P66. These coarse clasts were measured manually and removed from the sample that was subsequently analyzed by CVO. The hand-measured and sieved data were combined into a single sample grain-size distribution by (1) calculating particle mass of the individual measured particles assuming a particle density of $165 \mathrm{lb} / \mathrm{ft}^{3}\left(2.65 \mathrm{~g} / \mathrm{cm}^{3}\right)$ (Garcia, 2008) and (2) adding the mass of the individually measured particles to the mass distribution of the sieved material.

At cross sections P30 and P42 on the Puyallup River, no bars were exposed and bed material was too coarse to use the box dredge, so a shovel was used to scoop sediment from the riverbed in water less than 2-ft deep. Once a bucket was partially filled with sediment, the largest particles were measured and removed from the sample, and the smaller particles were bagged and sent to CVO for grain-size analysis. This technique is strongly biased toward sampling coarse particles because the fine particles washed off as the shovel was lifted through the water column.

\section{Characterizing Particle Size of Gravel Bars}

On the apex of most exposed gravel bars, the Wolman point-count method (Wolman, 1954) with a 100-ft tape measure aligned with the flow direction was used to measure grain-size distribution (fig. 12). All particles less than $2 \mathrm{~mm}$ were lumped into the less than $2 \mathrm{~mm}$ size category. On the Puyallup River near the confluence with the White River at cross sections P62 and P66, rather than laying the tape measure in a line, it was arranged in an alternating pattern covering an area of approximately $40 \mathrm{ft}^{2}$ and selecting particles every 6 in. along the line for measurement. Once the surface point count was performed, the surface layer was removed and a subsurface sample was collected into a bucket where the largest particles were measured, recorded, and removed from the sample. The smaller particles were then bagged (including sand) and sent to CVO for grain-size analysis.

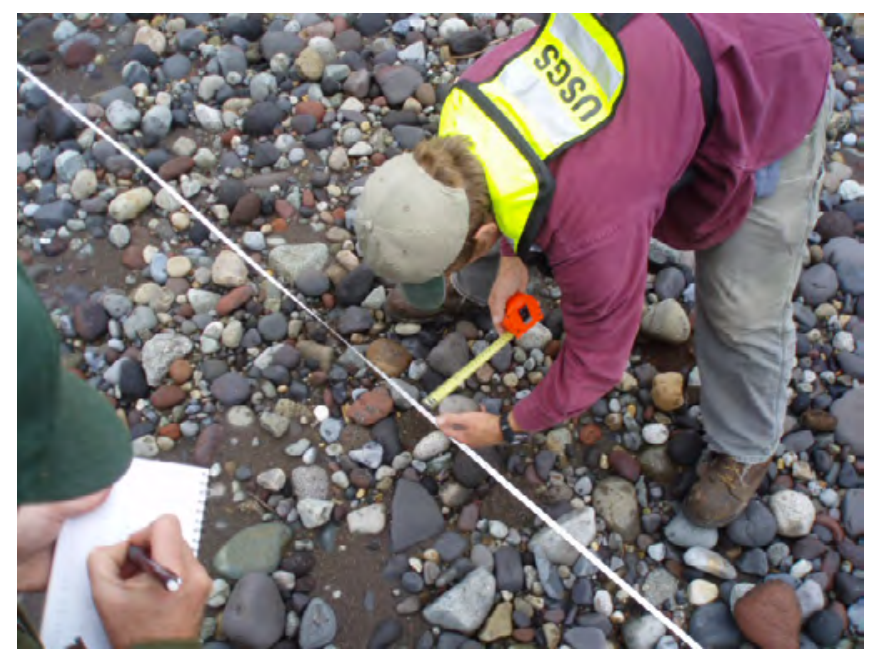

Figure 12. Method used to determine particle size of exposed cobble bars using the Wolman (1954) point-count method at cross section C35, Carbon River, western Washington, October 16, 2009. Photograph taken by Christopher Magirl, U.S. Geological Survey.

\section{Bed-Material Grain-Size Distributions}

The Wolman point-count method quantifies the sand percentage of the bed material, but does not resolve the full bed-material size distribution for material less than $2 \mathrm{~mm}$. All bed-material samples that included measurements of the sand distribution were averaged together to provide a size distribution for sand in the basin (fig. 13). This size distribution for sand was then appended to the truncated Wolman point-count samples to fully characterize the bed-material size distribution necessary for modeling. Additionally, bed-material size distributions measured in the White River by Herrera Environmental Consultants (2010) were modified for use in modeling. These samples included only size fractions for coarser material. Based on sand fractions measured in the upper Puyallup and Carbon Rivers, 30 percent of the sample was assumed to be sand and the average sand distribution was appended to the sample. The bed-material size distribution at each measurement location is shown in figures 14-16. 


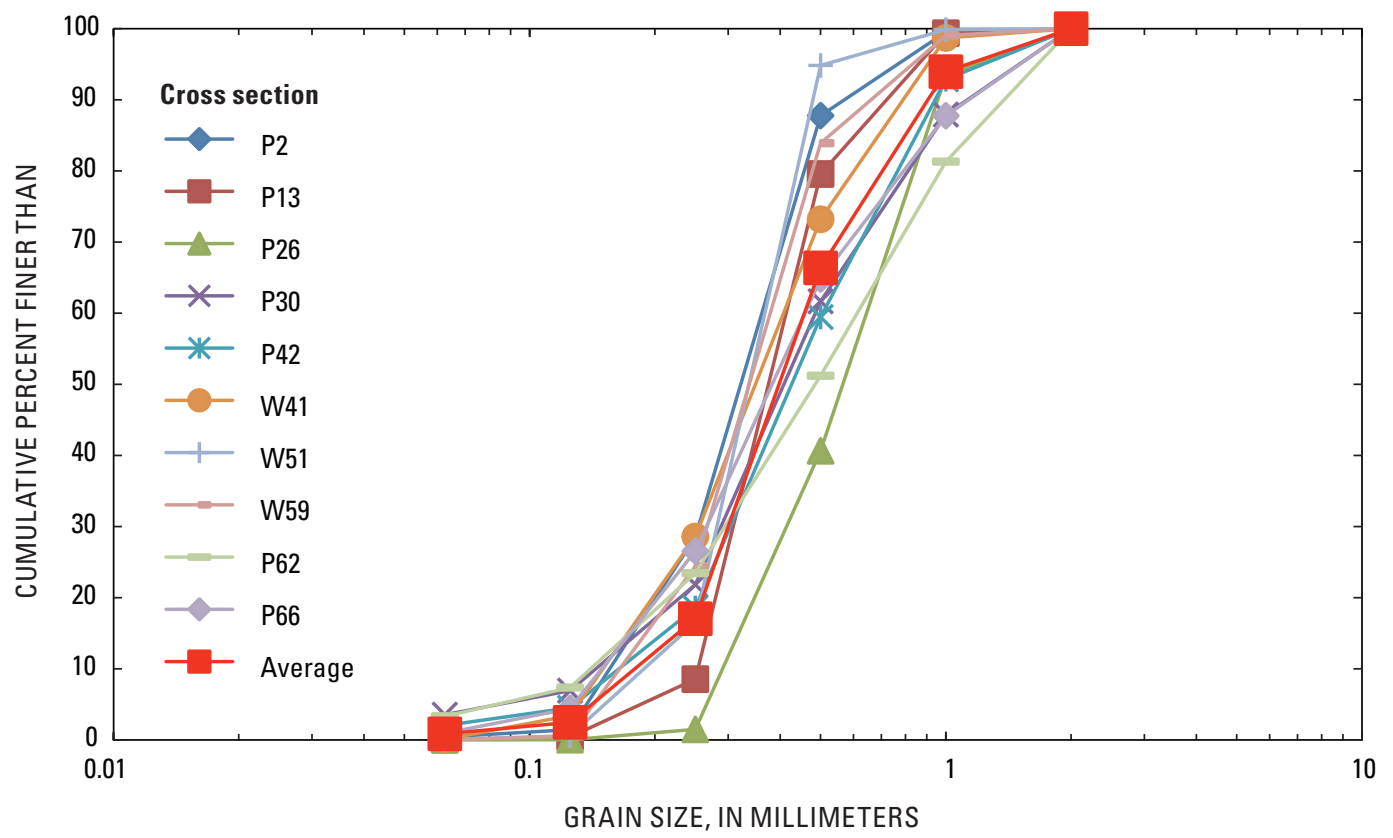

Figure 13. Measured sand distributions in the Puyallup and White Rivers, western Washington.

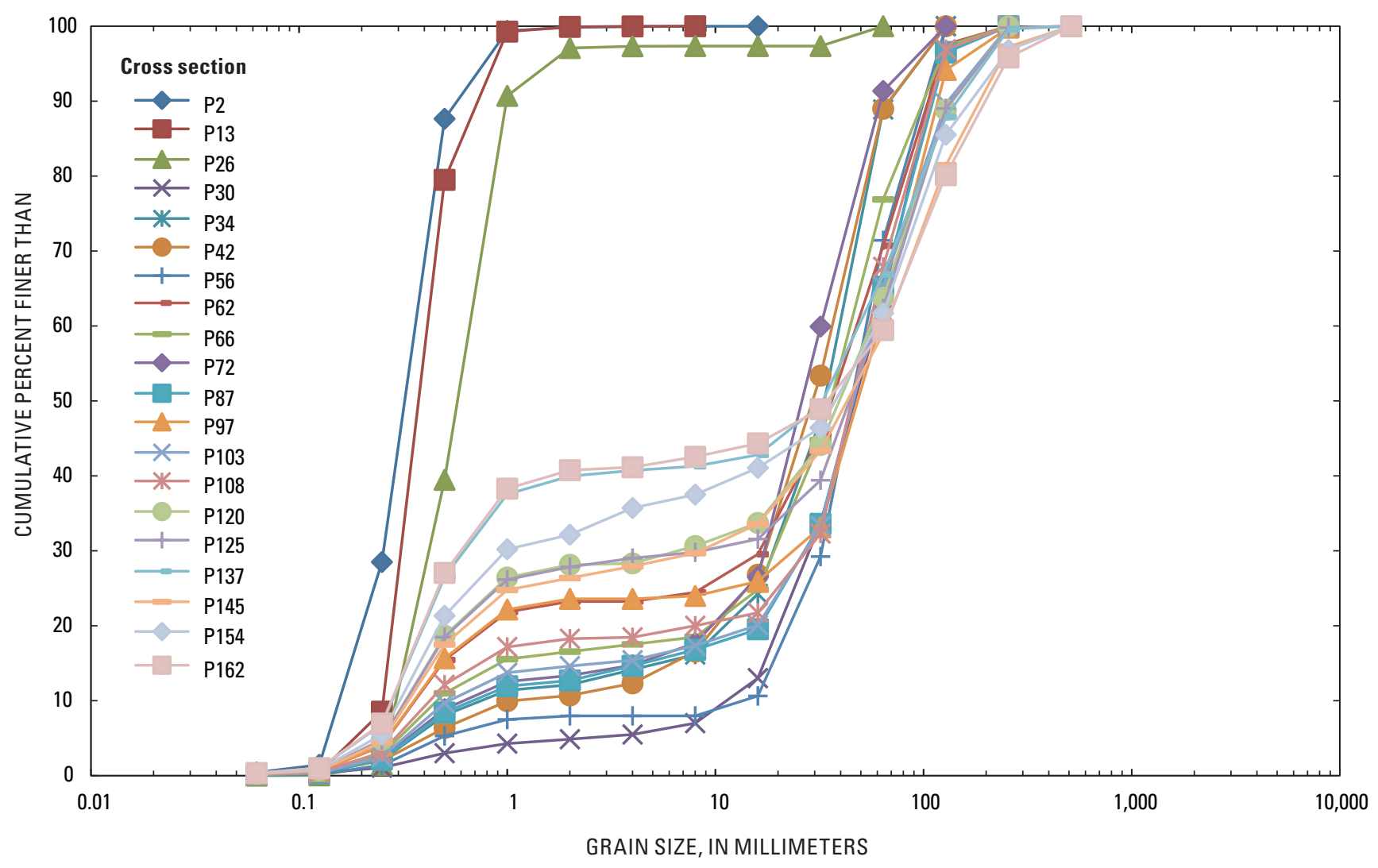

Figure 14. Bed-material grain-size distributions for the Puyallup River, western Washington. 


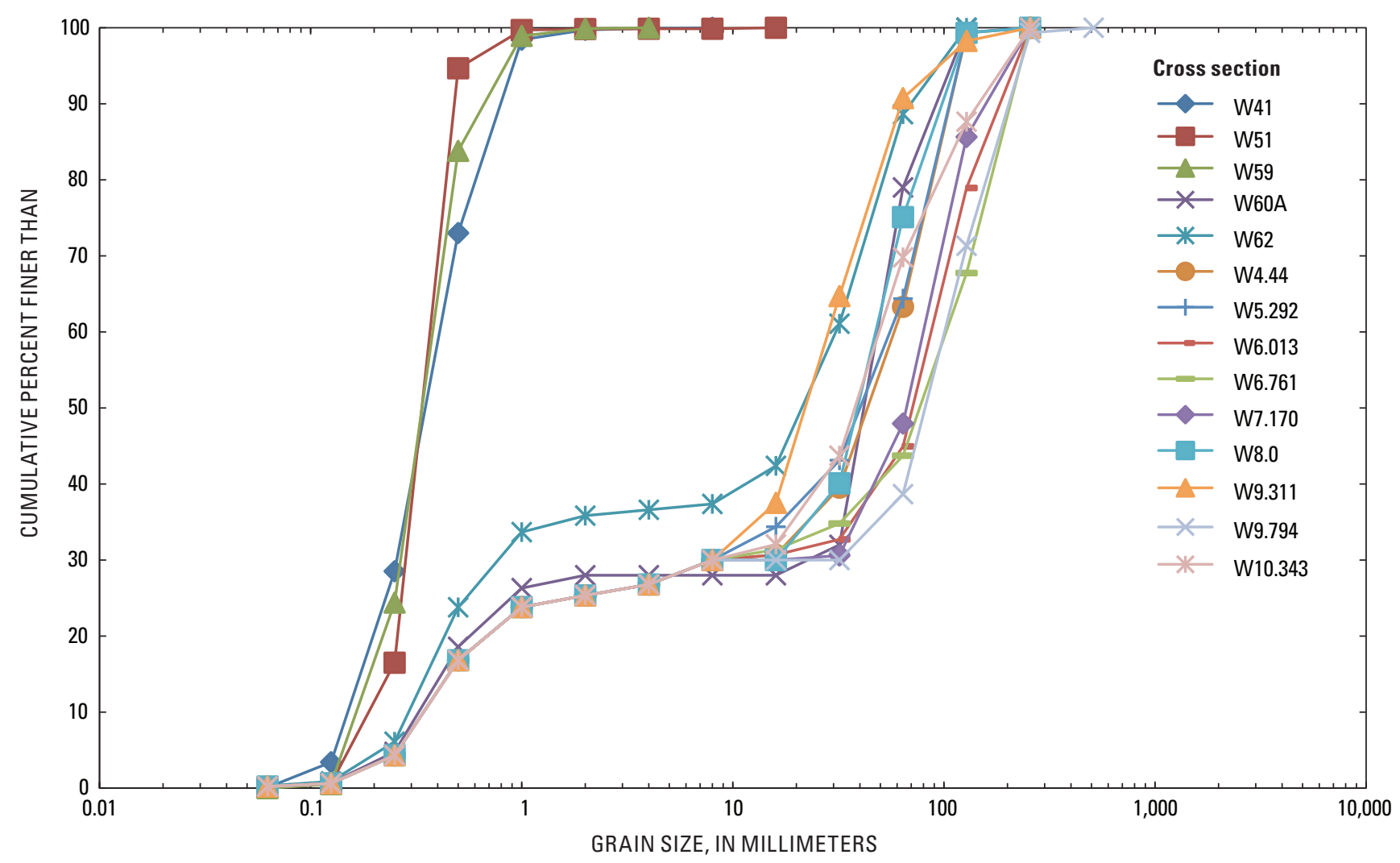

Figure 15. Bed-material grain-size distributions for the White River, western Washington.

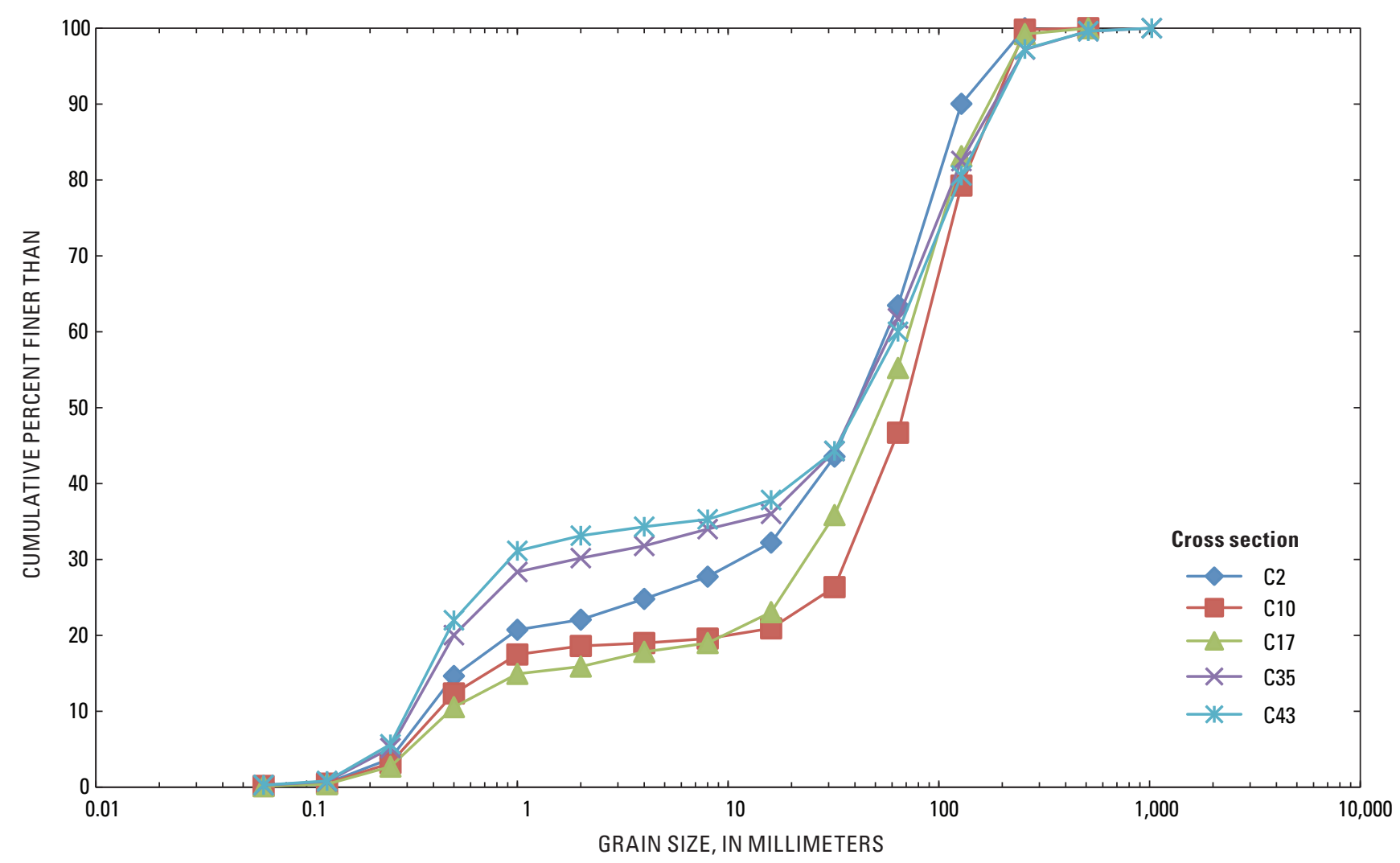

Figure 16. Bed-material grain-size distributions for the Carbon River, western Washington. 
The thalweg profile for the Puyallup, White, and Carbon Rivers is concave upward (fig. 17) with slope decreasing downstream, and bimodal bed-material grain-size distributions become finer downstream (figs. 14-16). The thalweg is the trace of the deepest point in the channel. Slope is directly related to sediment-transport capacity and the size of the bed-material. The capacity of the river to transport coarse sediment decreases as the slope decreases downstream, leaving the coarsest material behind. The slope of the White River near its mouth is less than the slope of the Puyallup River upstream of the confluence with the White River. Prior to the early 1900s, the White River flowed (alternating between avulsion events) north into the Green River and south into the Puyallup River. After a 1906 flood directed the White River to the south, the river-course realignment was made permanent with the construction of a walled revetment near White River RM 8 (fig. 2), or basin RM 18 (fig. 17). The slope of the White River channel steepens considerably upstream of White River RM 6, or basin RM 16 (fig. 17), and in the White River canyon. In contrast, the Carbon River is steeper than the Puyallup River, upstream of the confluence with the Carbon River, which is consistent with observations of stream-gradient relations between main stems and tributaries.

The bed-material grain-size distributions throughout the study area become finer downstream with sand dominating near the mouth of the Puyallup and White Rivers (fig. 18).

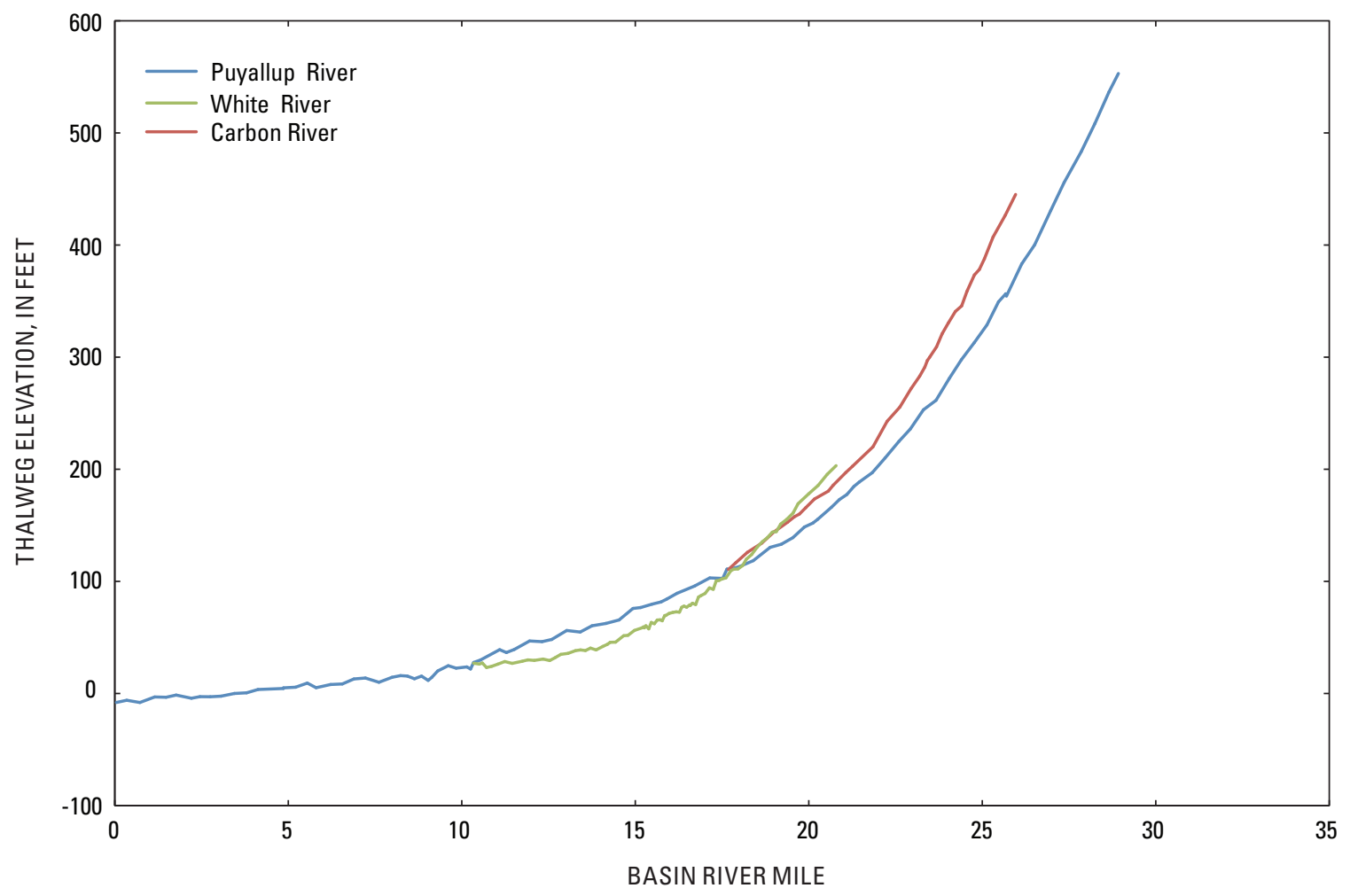

Figure 17. Thalweg elevation profiles using the 2009 cross sections for the Puyallup, White, and Carbon Rivers, western Washington. 


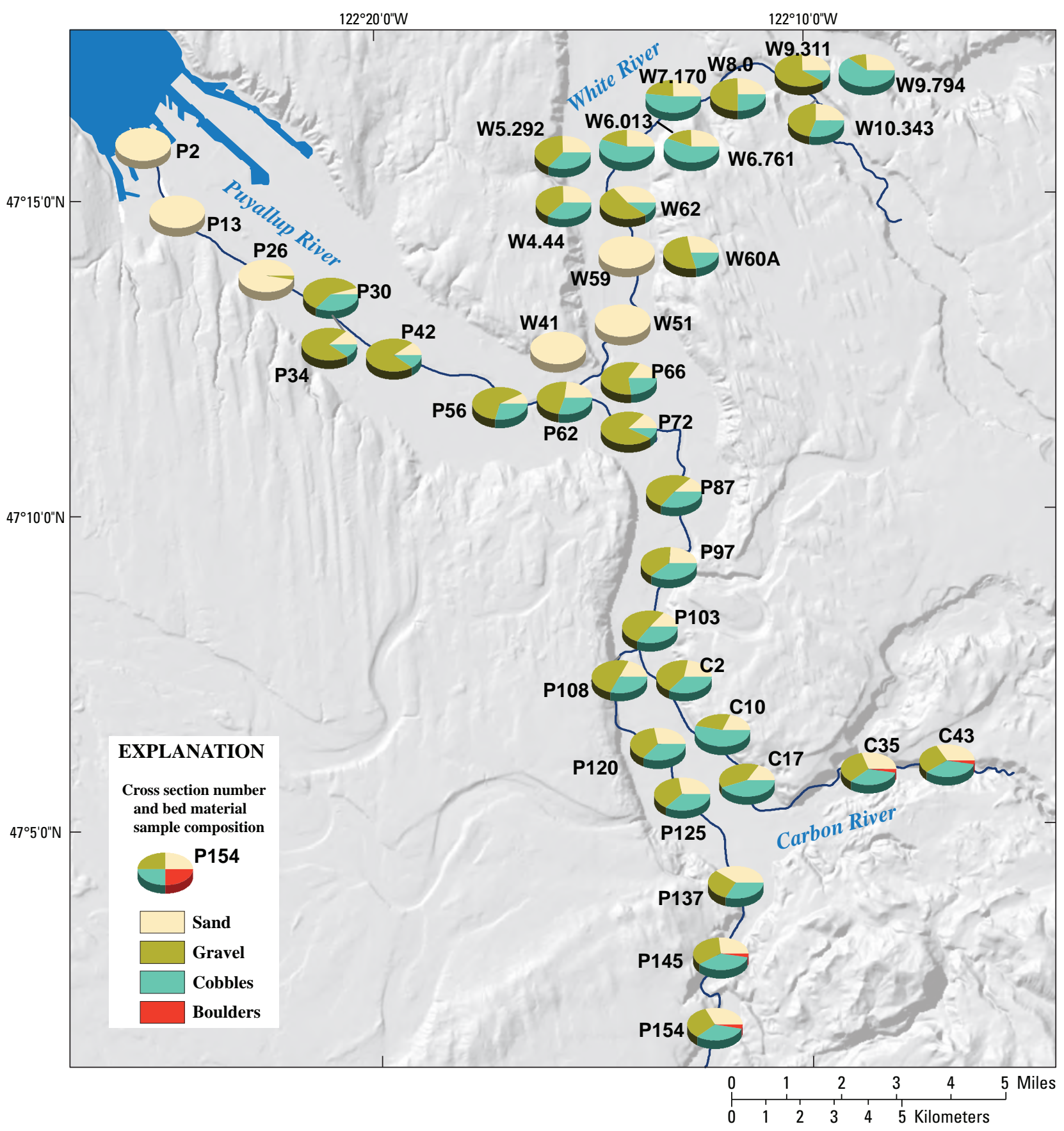

Figure 18. Bed-material size gradations for the Puyallup, White, and Carbon Rivers, western Washington from data collected in 2009. 
The D50 grain size for particles greater than $2 \mathrm{~mm}$ shows considerable variation away from Commencement Bay, however, the characteristic size of coarse sediment seems to be generally decreasing downstream (fig. 19). The downstream decrease in bed-material size may be due to selective transport of the finer sediment, attrition, a tendency for downstream tributaries to supply finer sediment, or some combination of the above (Paola and others, 1992; Parker, 2008). Selective transport of the finer sediment, or selective deposition of the coarse sediment, is a sedimentary fractionization process. Paola and others (1992) suggested that downstream fining by selective deposition would occur through the transport and deposition of bimodal gravel, independent of variable discharge (temporal or spatial) or variations in preexisting slope. Attrition is the size reduction of clasts due to rock impact and also rounds and smoothes particles. Bed-material grain-sizes in the upper Puyallup and Carbon Rivers are similar, and bed-material sizes in the lower Puyallup River just downstream of the confluence with the White River do not reflect increased input from sand, which would rule out the possibility that downstream tributaries supply finer sediment as the dominant mechanism for downstream fining. The general downstream decrease in the bed-material size is likely due to downstream fining by selective deposition as well as attrition.
The surface bed-material size distributions measured at the end of October through early November 2009 show the areas with the lowest slopes (fig. 17), near the mouth of the Puyallup and White Rivers, are composed of sandsized material; with a bimodal bed-material size distribution of sand, gravel, and cobbles just upstream (fig. 18). Three causes for a transition from gravel to sand bed were proposed by Sambrook Smith and Ferguson (1995): (1) local baselevel control, (2) lateral input of fine sediment, and (3) abrasion or breakdown of material. Abrasion or breakdown of sediment generally occurs in high-energy environments where gravel breaks down into individual mineral grains. The existence of cobbles upstream of the observed gravel/ sand transition indicates that the transition is not due to the abrupt disintegration of gravel into mineral grains. Another cause of a gravel/sand transition is through the lateral input of fine sediment where the bed becomes dominated by sand. However, there are no large sources of fine sediment upstream of the transition. A large body of water or a main channel can be a downstream water-surface control that acts as a local base-level control, which lowers water-surface slopes upstream. In areas with low water-surface slopes only sand is mobile and sand accumulates on the bed until a sand bed forms.

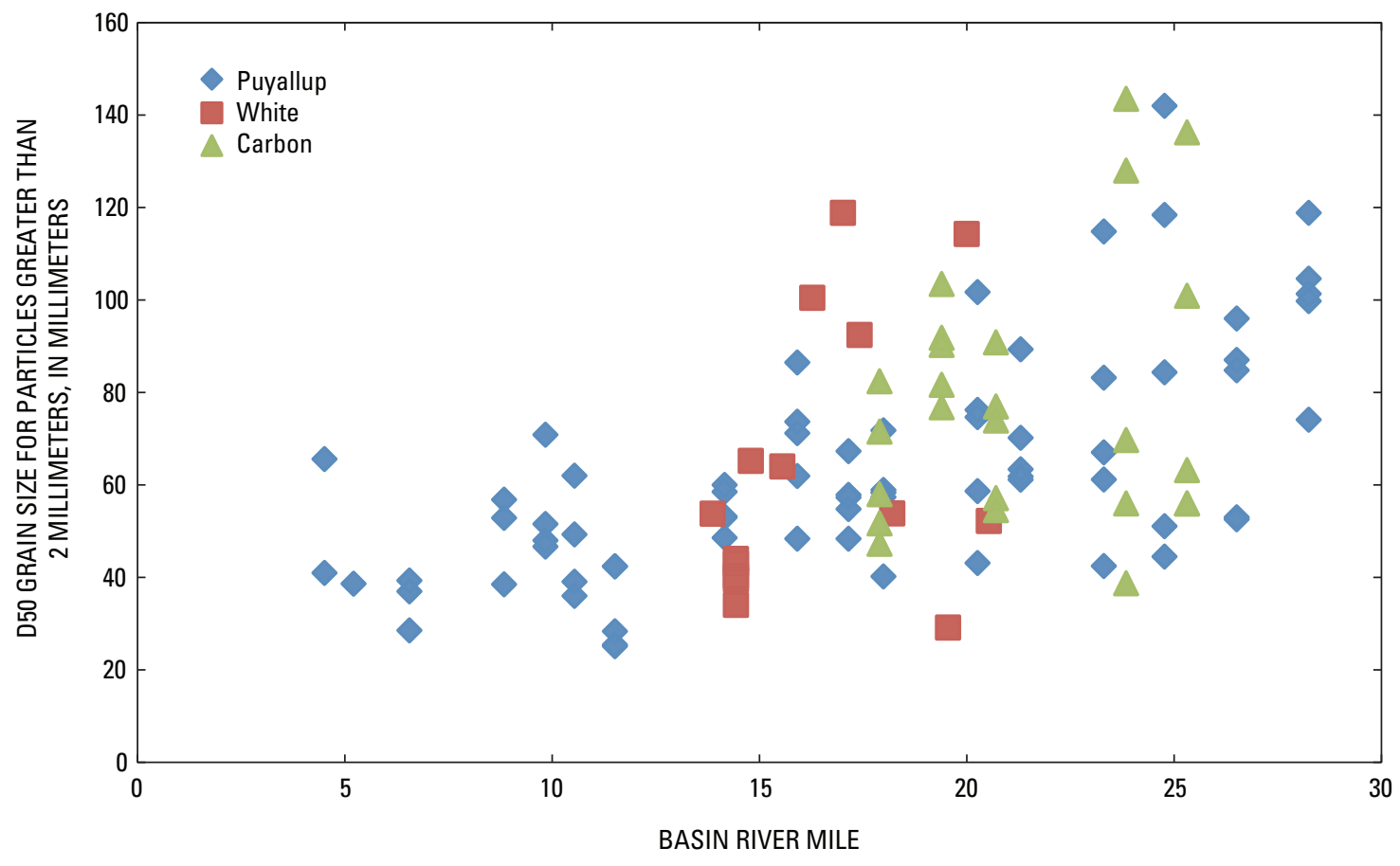

Figure 19. D50 grain size for particles greater than 2 millimeters measured in 2009 in the Puyallup, White, and Carbon Rivers, western Washington. (D50 is the grain sizes at which 50 percent of the material in the distribution is finer than.) 
The percentage of sand composing the bed-material compared to the slope in the Puyallup, White, and Carbon Rivers indicates that sand dominates in the regions of lowest slopes (fig. 20). The gravel/sand transition near the mouth of the White River occurred at approximately White River RM 3.5 on November 4, 2009 and corresponds to where the slope decreases below about 0.08 percent. The slope is low in the lower $3.5 \mathrm{mi}$ of the White River because the Puyallup River backs up the flow in the White River, and acts as a local base-level control. The gravel/sand transition near the mouth of the Puyallup River occurred at about RM 4 on October 14, 2009 , and corresponds to the extent of tidal influence where the slope decreases to less than about 0.05 percent. The location of the gravel/sand transition in the lower Puyallup River is caused by the tidal influence of Puget Sound, which acts as a local base-level control.

During sample collection downstream of the gravel/sand transition, sand seemed to have mantled a coarser substrate below. At the time of sediment-data collection, the water in the White River was turbid and active sand transport was occurring. Sand boils were observed lifting sand to the water surface. On April 16, 2010, at the location of the November 4, 2009 gravel/sand transition on the White River, the flow was similar but the water was clear, no active sand transport was observed, and the bed was coarser (the clear water revealed the coarse substrate). The gravel/sand transition seemed to have moved downstream between November 2009 and April 2010.

The location of a sand/gravel transition is a transient feature that depends on the antecedent flow conditions and the capacity for those flows to transport various sizes of sediment. During sediment-laden moderate to high flows with a high water-surface elevation control downstream, sand may deposit in the reaches with the lowest water-surface slopes causing the gravel/sand transition to move upstream. During moderate to low flows without a significant sediment load and a lower

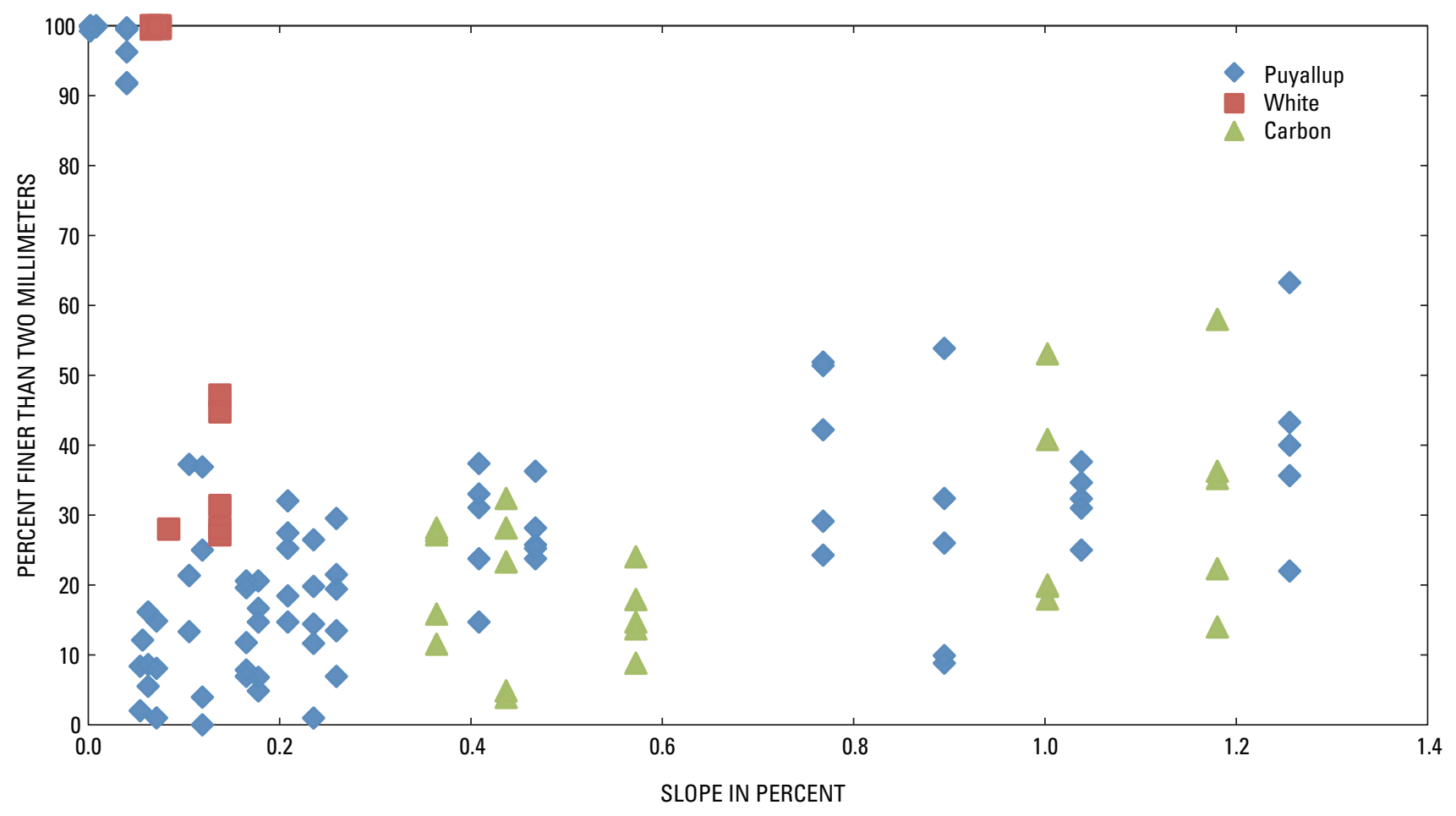

Figure 20. Percentage of sand composing the bed material measured in 2009 compared to the slope in the Puyallup, White, and Carbon Rivers, western Washington. 
water-surface elevation control downstream, sand-sized material may be winnowed away and coarsen the surface of the wetted channel causing the gravel/sand transition to move downstream.

A transient gravel/sand transition may have significant implications for the measured channel elevations near the transition. The measured channel elevations could be high or low, compared to the long-term average channel elevation, because of the location of the gravel/sand transition when channel cross sections were measured. Simulations of flood elevations based on measured channel cross sections could be high or low near the gravel/sand transition depending on the antecedent flow conditions. No concurrent measurements of channel elevation, gravel/sand transition location, and sand thickness (possibly mantling a coarser substrate) to quantify the variability in channel elevation near the gravel/sand transition, have been made in the Puyallup or White Rivers as the gravel/sand transition migrates in time.

\section{Comparison of Particle Sizes Measured in the 1980s and 2009}

Bed-material size distributions on the surface of gravel bars were measured several times between 1984 and 1986 using the Wolman point-count method at several locations in the Puyallup, White, and Carbon Rivers (Sikonia, 1990). The D50 grain size for particles greater than $2 \mathrm{~mm}$ for each measurement sample collected in 2009 were compared to Sikonia’s (1990) data along each river (figs. 21-23).

Considerable scatter in the data was noted and relatively few bed-material size distributions were measured on the White and Carbon Rivers. Considering the scatter in the data, the bed-material size distributions measured in 2009 have not changed from those measured by Sikonia (1990). The stability of the grain-size distributions indicates that as sediment is transported through the system, sediment deposits at specific locations through downstream fining by selective deposition in addition to attrition (Paola and others, 1992).

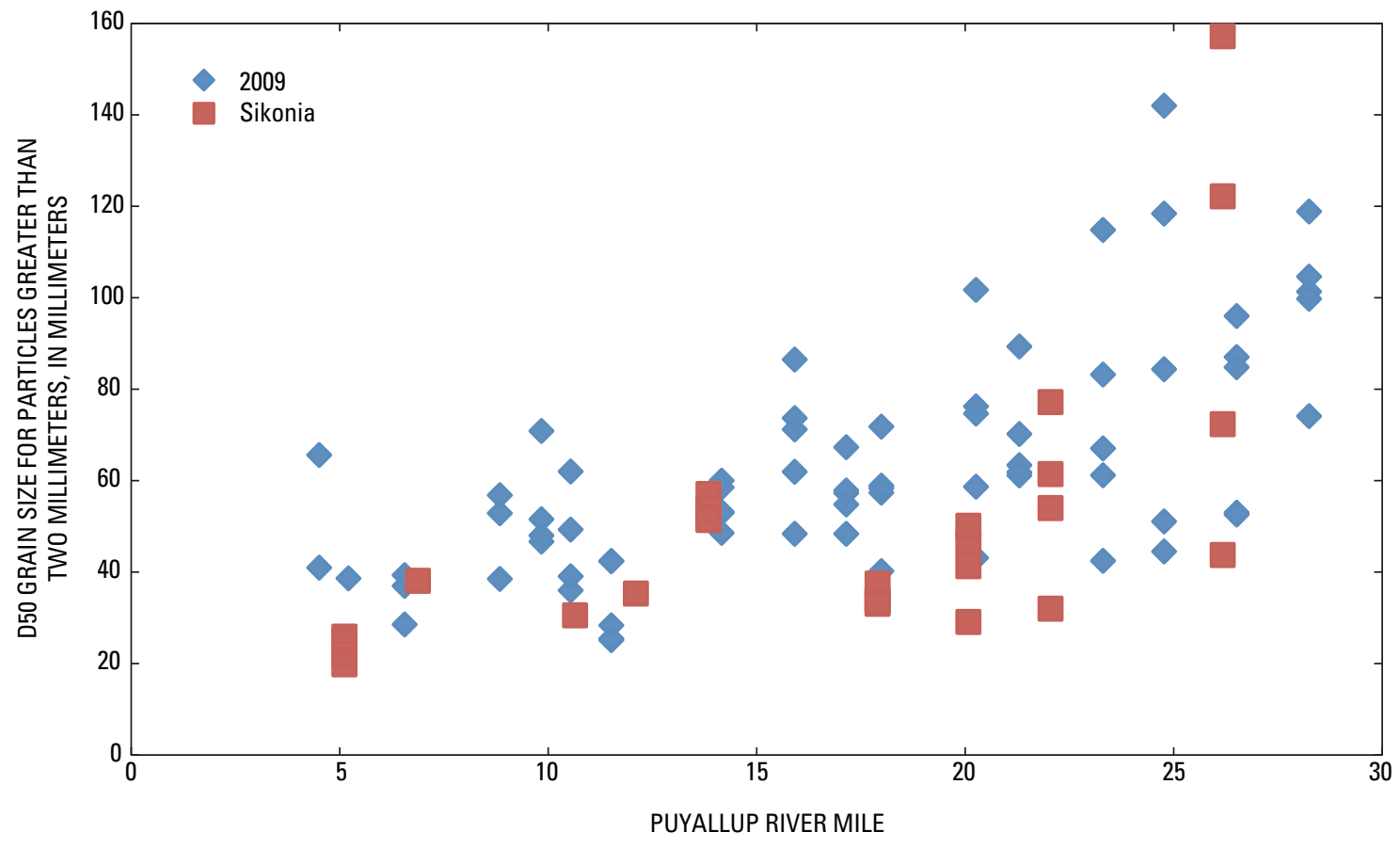

Figure 21. Comparison of the D50 grain size for particles greater than 2 millimeters measured in 2009 to those measured by Sikonia (1990) for the Puyallup River, western Washington. (D50 is the grain sizes at which 50 percent of the material in the distribution is finer than.) 


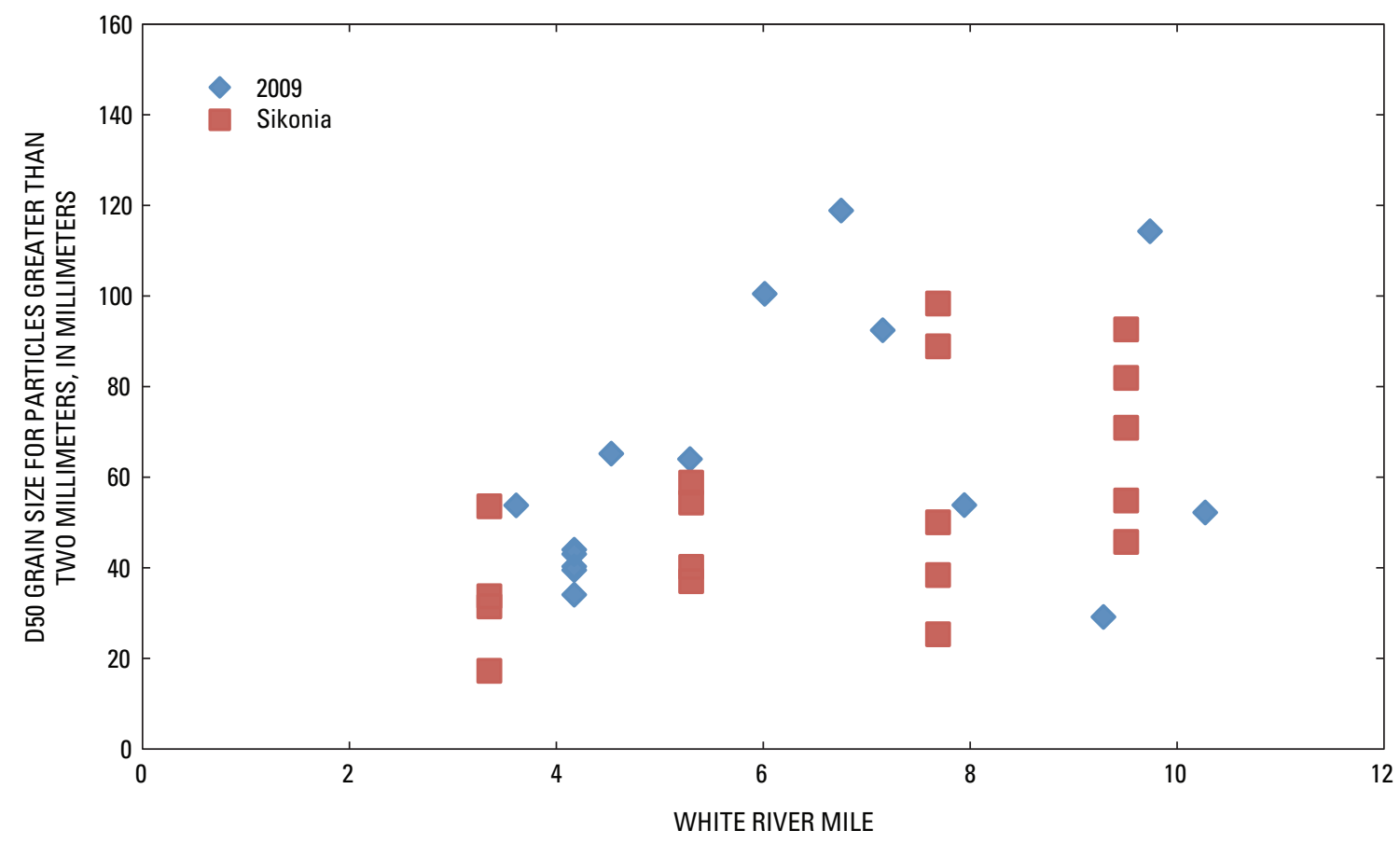

Figure 22. Comparison of the D50 grain size for particles greater than 2 millimeters measured in 2009 to those measured by Sikonia (1990) for the White River, western Washington. (D50 is the grain sizes at which 50 percent of the material in the distribution is finer than.)

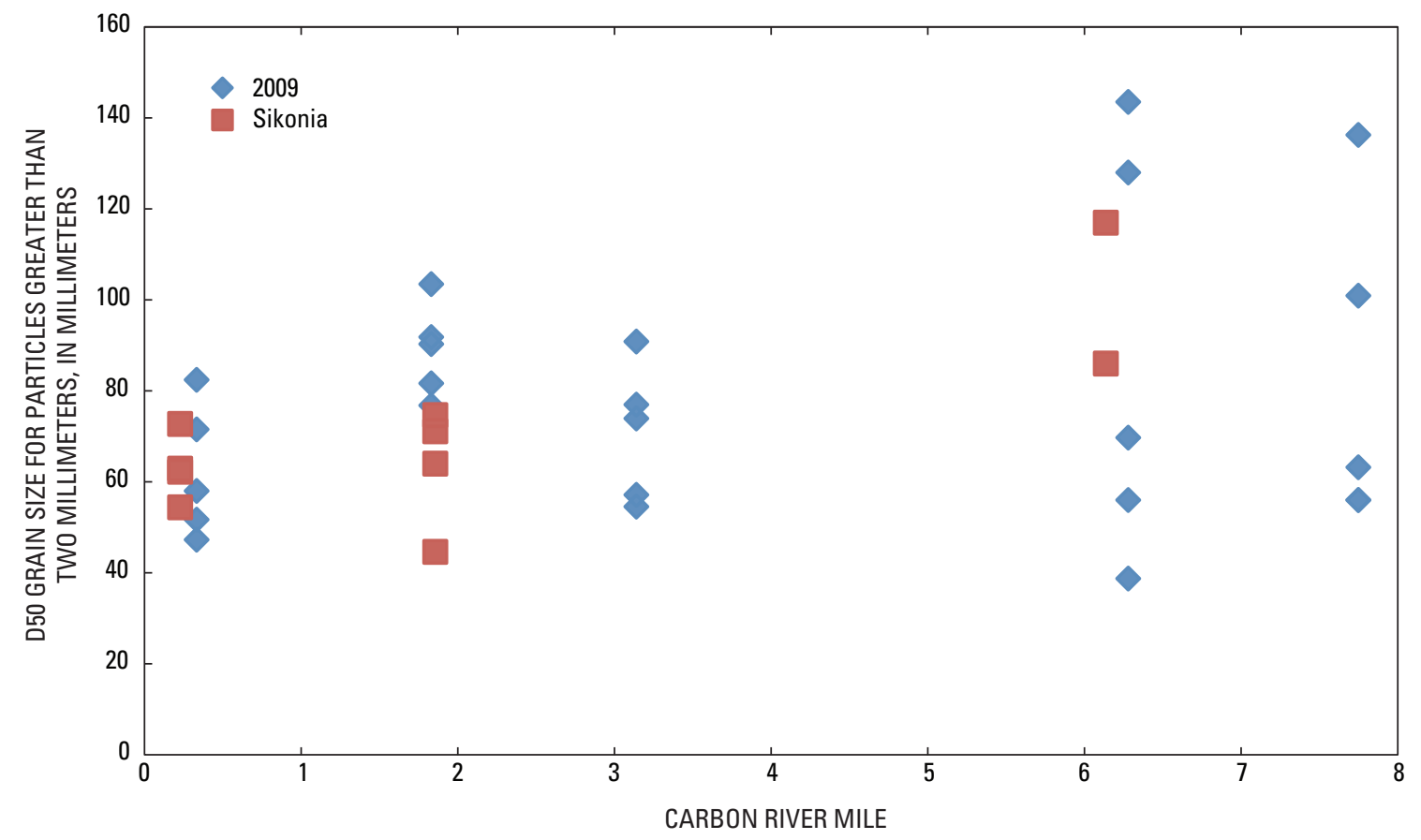

Figure 23. Comparison of the D50 grain size for particles greater than 2 millimeters measured in 2009 to those measured by Sikonia (1990) for the Carbon River, western Washington. (D50 is the grain sizes at which 50 percent of the material in the distribution is finer than.) 


\section{Flow-Conveyance Changes at Streamflow-Gaging Stations}

The USGS operates and maintains a network of streamflow-gaging stations throughout the State of Washington including many gaging stations in the Puyallup River drainage basin and other rivers draining Mount Rainier. All measured gaging-station data are published in USGS reports and are reported through the National Water Information System (NWIS). Accuracy for discharges recorded by USGS usually is within 5 percent (Rantz, 1982).

The USGS follows standard procedures that govern the installation and operation of its stream-gage network (Rantz, 1982). This quality control facilitates the analysis of longterm data sets and comparison of temporal trends measured by the same gaging station as well as comparison between gaging stations. Analyzing gaging-station data through time allows the quantification of geomorphic trends in channel elevation, channel-conveyance capacity, and stage (Juracek and Fitzpatrick, 2009). For example, Prych (1988) analyzed data from USGS gaging stations on the Puyallup and White Rivers to infer trends in aggradation and incision since the early 1900s. Elsewhere in Washington, Collins and Dunne (1989) used stream-gage analysis on the Humptulips, Satsop, and Wynoochee Rivers to attribute channel-bed degradation to gravel extraction, and Stover and Montgomery (2001) used gaging-station data to document channel aggradation and incision on the Skokomish River.

When installing gaging stations (to ensure long-term stability and reliability) stream gagers prefer to select sections of rivers that are controlled by bedrock where influences from alluvium are minimized. Site access, cost, and safety considerations, however, often force the placement of gaging stations at sites where hydraulic control and bed elevations are influenced by alluvium. During operation of a gaging station, USGS stream gagers visit the site periodically to measure discharge at different river stages in order to assemble and update a stage-discharge rating curve. If hydraulic control at a gaging site changes through time, the stage for a given discharge at the site also will change, requiring modifications or "shifts" in the stage-discharge rating curve. Most modifications are made under the assumption that the stage-discharge rating for large flows remains constant, thus anchoring the upper end of the rating; the rating curve is shifted only for low discharges. When discharge measurements are made at high flows that justify a change at the high end of the rating curve, the entire stage-discharge rating is often updated. Occasionally, gaging stations are moved or repositioned, which results in changes to the gage datum.

\section{Analysis Methods}

Trends in stream-gaging data were analyzed from 12 USGS gaging stations in the Mount Rainier drainage basin (table 6); although not all gaging stations were on rivers directly draining the glaciated terrain of Mount Rainier. Channel morphology in streams draining glaciers tends to be more variable than rivers not draining glaciers due to enhanced sediment supply (James Tilque, U.S. Geological Survey, written commun., 2010). Ten gaging stations were located on rivers draining glaciated Mount Rainer. Data from four gaging stations on the Puyallup River were analyzed: station 12101500, Puyallup River at Puyallup; station 12096500 , Puyallup River at Alderton; station 12093500, Puyallup River near Orting; and station 12092000, Puyallup River near Electron. Data from three gaging stations on the White River were analyzed: station 12100500 White River near Sumner; station 12100496, White River near Auburn; and station 12098500, White River near Buckley. Data from one gaging station each on the Carbon, Nisqually, and Cowlitz Rivers also were analyzed: station 12094000, Carbon River near Fairfax; station 12082500, Nisqually River near National; and station 14226500, Cowlitz River at Packwood. Finally, data were analyzed from two gaging stations on rivers not draining glaciated Mount Rainier: station 12097500, Greenwater River at Greenwater; and station 12095000, South Prairie Creek at South Prairie, which allowed for comparisons of variation and trends between glaciated and non-glaciated terrain.

For all 12 gaging stations, the stage at high, median, and low discharges were determined from the gaging station period of record (table 6). The high discharge was defined as the daily mean discharge that is exceeded 10 percent of the time (10 percent exceedance), the median discharge is the daily mean discharge that is exceeded 50 percent of the time (50 percent exceedance), and the low discharge was defined as the daily mean discharge that is exceeded 90 percent of the time (90 percent exceedance). Data collected after about 1987 were queried from digital data sets in NWIS. From daily values of coupled stage and discharge, records with values within 2 percent of the target discharge were collected and analyzed for trends in the corresponding stage. Few pre-1980s digital data are available in NWIS. For these earlier years, data were manually assembled from stage-discharge rating curves contained in hardcopy files located in the USGS Washington Water Science Center.

Trends in stage at the median discharge for the 12 evaluated gaging stations were determined by applying a linear regression model to measured stage data. The trend analysis focused on the three decades following the Prych (1988) analysis, although the exact years analyzed depended on availability of data or unusual trends within the data. 
Table 6. Streamflow-gaging stations in the study area analyzed for trends in stage for selected streamflow-gaging stations in western Washington.

[Location of streamflow-gaging stations are shown in figure 1. Abbreviations $\mathrm{mi}^{2}$, square mile; $\mathrm{ft}^{3} / \mathrm{s}$, cubic foot per second]

\begin{tabular}{|c|c|c|c|c|c|c|c|}
\hline \multirow{2}{*}{$\begin{array}{l}\text { Streamflow- } \\
\text { gaging station } \\
\text { No. }\end{array}$} & \multirow{2}{*}{ Station name } & \multirow{2}{*}{$\begin{array}{l}\text { Period of } \\
\text { record }\end{array}$} & \multirow{2}{*}{$\begin{array}{l}\text { Total years } \\
\text { of data } \\
\text { analyzed }\end{array}$} & \multirow{2}{*}{$\begin{array}{c}\text { Drainage } \\
\text { area } \\
\left(\mathrm{mi}^{2}\right)\end{array}$} & \multicolumn{3}{|c|}{$\begin{array}{l}\text { Daily mean discharge }\left(\mathrm{ft}^{3} / \mathrm{s}\right) \\
\text { exceeded for indicated period }\end{array}$} \\
\hline & & & & & 10 percent & 50 percent & 90 percent \\
\hline 12101500 & Puyallup River at Puyallup & 1914-2009 & 95 & 948 & 5,620 & 2,750 & 1,400 \\
\hline 12096500 & Puyallup River at Alderton & $\begin{array}{l}\text { 1914-1926; } \\
\text { 1943-1955; } \\
\text { 1981-2008 }\end{array}$ & 48 & 438 & 2,760 & 1,360 & 715 \\
\hline 12093500 & Puyallup River near Orting & 1931-2009 & 78 & 172 & 1,180 & 588 & 310 \\
\hline 12092000 & Puyallup River near Electron & $\begin{array}{l}\text { 1908-1933; } \\
\text { 1944-1949; } \\
\text { 1957-2010 }\end{array}$ & 82 & 92.8 & 894 & 440 & 220 \\
\hline 12100500 & White River near Sumner & 1945-1971 & 26 & 470 & 1,840 & 198 & 78 \\
\hline 12100496 & White River near Auburn & $1987-2010$ & 23 & 464 & 2,020 & 500 & 175 \\
\hline 12098500 & White River near Buckley & 1938-2003 & 65 & 401 & 2,590 & 1,150 & 479 \\
\hline 12094000 & Carbon River near Fairfax & $\begin{array}{l}\text { 1929-1978; } \\
\text { 1991-2009 }\end{array}$ & 67 & 78.9 & 764 & 336 & 157 \\
\hline 12082500 & Nisqually River near National & 1942-2009 & 67 & 133 & 1,340 & 628 & 318 \\
\hline 14226500 & Cowlitz River at Packwood & 1929-2009 & 88 & 287 & 3,350 & 1,100 & 448 \\
\hline 12097500 & Greenwater River at Greenwater & $\begin{array}{l}\text { 1929-1977; } \\
\text { 1980-2009 }\end{array}$ & 77 & 73.5 & 450 & 144 & 43 \\
\hline 12095000 & South Prairie Creek at South Prairie & 1987-2009 & 22 & 79.5 & 448 & 172 & 45 \\
\hline
\end{tabular}

For most data analyzed, stage for a given discharge usually changed in steps tied to large peak events. Although

application of a linear model to these data usually is a poor approximation for the complex response of the data, the linear model does offer a consistent and objective way to evaluate overall trends. The variability in stage for a given discharge over the period of evaluation was quantified by calculating the standard deviation of the data (table 6).

A time series of the theoretical overtopping discharge in the river section at four gaging stations was compiled (station 12101500, Puyallup River at Puyallup; station 12096500, Puyallup River at Alderton; station 12093500, Puyallup River near Orting; and station 12100496; White River near Auburn) using the rating curve for each gaging station. The theoretical overtopping discharge was defined as the discharge at which the water-surface elevation in the channel would begin to overtop the right or left bank, whichever was lower. The lower elevation of the right and left banks was determined from the 2009 surveyed cross section closest to the gaging station and was assumed to have remained constant since 1986.
The banks are generally stable levees and the cross-section comparison between 2009 and 1984 generally matched at the banks, which justified the use of the 2009 bank elevation for this analysis. The overtopping discharge was estimated every time the stage-discharge rating was shifted, which provided a time-series of theoretical overtopping discharge using the stage-discharge rating for each gaging station. The theoretical overtopping discharge generally was much larger than the discharge measurements used to establish the stage-discharge relation. Therefore, the estimate of the overtopping discharge often represents an extrapolation of the measured discharge to higher flows. Depending on the degree of extrapolation, the overtopping discharge can be highly uncertain. Additionally, the overtopping discharge at the particular gaging station would rarely, in theory, be reached because levees and banks downstream of the analyzed gaging station would be compromised at lower discharges, further increasing the uncertainty in the extrapolated upper end of the stagedischarge relation. This analytical technique can be useful in illustrating temporal trends in high-flow conveyance. 
For the White River near Auburn gaging station (12100496), the trends in stage at 9,000 and $12,000 \mathrm{ft}^{3} / \mathrm{s}-$ within the range of high-flow discharges released from MMD by the USACE for flood protection on the lower Puyallup River-were determined for 1987-2009. This section of the White River has been subjected to significant aggradation (Dunne, 1986; Prych, 1988; Herrera Environmental Consultants, 2010), leading to compromised flood-conveyance capacity (U.S. Army Corps of Engineers, 2009).

\section{Stage at High, Median, and Low Discharges}

Changes in stage for a given discharge can be caused by any number of factors that affect flow conveyance, and include modifications to the channel geometry or water velocity. The changes in stage for a given discharge at gaging stations were interpreted as changes in channel-bed elevation, through aggradation and incision, at the hydraulic control.

\section{Puyallup River}

The gaging station on the Puyallup River at Puyallup (121015000) is the farthest downstream in the network and the period of record extends back to 1913. For this study, data from 1914 and after were collected and displayed (fig. 24). Prych (1988) analyzed the stage that corresponded to 10 percent exceedance flow from the same gaging station until 1985, which allowed for direct comparison of current gage-analysis methods with Prych's methods for this and three other gaging stations. In all cases, the data collected for this study and Prych's (1988) data agreed, which validated the approach used for collecting non-digital, pre-1980s data from hardcopy files. Prych (1988) attributed the 5-ft drop at the Puyallup gaging station from 1916 to 1917 to channel modifications following the establishment of ICRI. Prych (1988) suggested that another 3-ft drop in the 1930s probably resulted from gravel removal for the construction of Highway 167 along the left bank of the river near the gaging station. From 1955 to 1985 Prych (1988) noted a slow, steady increase in stage of about $0.5 \mathrm{ft}$, a rate of change of about $0.2 \mathrm{in} / \mathrm{yr}$. Since 1985, data showed a similar slow, steady increase on the lower Puyallup River with an overall aggradation rate of about $0.3 \mathrm{in} / \mathrm{yr}$ resulting in an overall change of approximately $0.6 \mathrm{ft}$ between 1985 and 2009.

Prych (1988) also analyzed trends in stage at the 10 percent exceedance discharge for the Puyallup River at Alderton (12096500) and Puyallup River near Orting (12093500) gaging stations. The record at Alderton is discontinuous with three primary periods of collection: 1914-26, 1943-55, and 1981-2008. Prych (1988) attributed an initial decrease of about $2 \mathrm{ft}$ in stage between 1915 and 1920 to extensive channel work by ICRI. After 1920, Prych also noted a slow but continuous decrease in stage for a given discharge of about $1 \mathrm{in} / \mathrm{yr}$ until about 1984, when a few miscellaneous measurements were made between 1981 and 1984. Prych could not definitively explain the cause of the slow decreasing stage between 1920 and 1984, although he indicated that the incision could be a response to the original ICRI work and ongoing gravel removal.

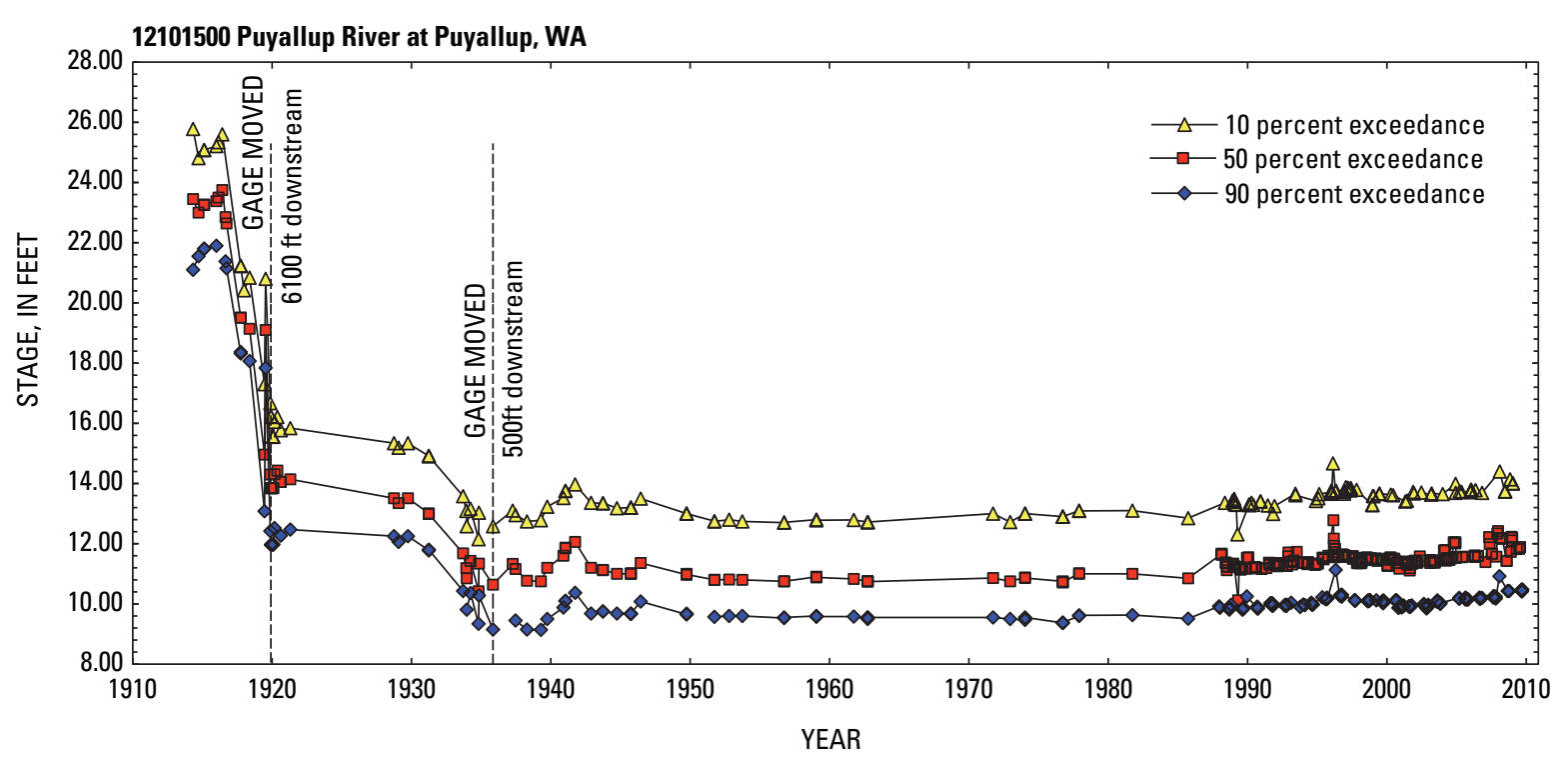

Figure 24. Stage for the period of record at 10,50, and 90 percent exceedance for gaging station 12101500, Puyallup River at Puyallup, Washington. 
Between 1974 and 1984, about 1 million cubic yards of predominantly gravel-sized sediment was removed from the Puyallup River (table 1) with most removal occurring between Orting and the confluence with the White River. Between 1984 and 1992, the stage at the Alderton gaging station had largely stabilized with little change. The gaging station was reactivated for continuous measurements in 1991. Since 1993, the gaging station at Alderton has been relatively stable with hydraulic control provided by downstream cobble bars (James Tilque, U.S. Geological Survey, written commun., 2010). The gage readings for low-exceedance flows, however, have been unreliable due to the transient surging of high flows against the S.R. 162 bridge just downstream of the gaging station (Randy Brake, Pierce County, written commun., 2010). The stage for a given discharge increased almost $1 \mathrm{ft}$ in 1996 before returning to pre-1996 elevation in 1997 followed by generally constant stage until 2006. After large discharge events in 2006, the stage again increased by about $0.5 \mathrm{ft}$. The average increase in stage for a given discharge between 1992 and 2008 was about $0.1 \mathrm{in} / \mathrm{yr}$ and $0.13 \mathrm{ft}$ overall.

For the gaging station on the Puyallup River near Orting (12093500), Prych (1988) noted a general decrease in stage for a given discharge of about $4 \mathrm{ft}$ from 1955 to 1975. From 1977 to 1984, Prych noted a slight increase in the stage at the Orting gaging station of about $0.8 \mathrm{ft}$. From the 1980 s to 2009, the stage for a given discharge in the reach of river at the Orting gaging station has fluctuated, which is indicative of a river located downstream of glaciated headwaters. The overall trend in stage at median flow decreased between 1988 and 2009 by $0.5 \mathrm{in} / \mathrm{yr}$ and $0.9 \mathrm{ft}$ overall.

Prych (1988) analyzed no other gaging stations on the Puyallup River. The analysis described in this report also includes data from the Puyallup River at Electron (12092000), which has been operated from 1908 to 1933, 1944 to 1949, and 1957 to 2010 . Although the gaging station was moved multiple times throughout its periods of record, the data set is useful in explaining river tendencies near the gaging station (fig. 25), which is on the most upstream section of the Puyallup River. Owing to its proximity to Mount Rainier glaciers, the stage for a given discharge at this gaging station has fluctuated throughout the period of record, although no general trends dominate. Between 1987 and November 2006, a relatively steady decrease in stage of about $0.5 \mathrm{ft}$ was measured. Between 2006 and 2010, however, stage increased dramatically following high discharge events in November 2006 and November 2008. In 2009, the stage was about $2 \mathrm{ft}$ greater than the elevation in 2005.

\section{Puyallup River near Electron, WA}

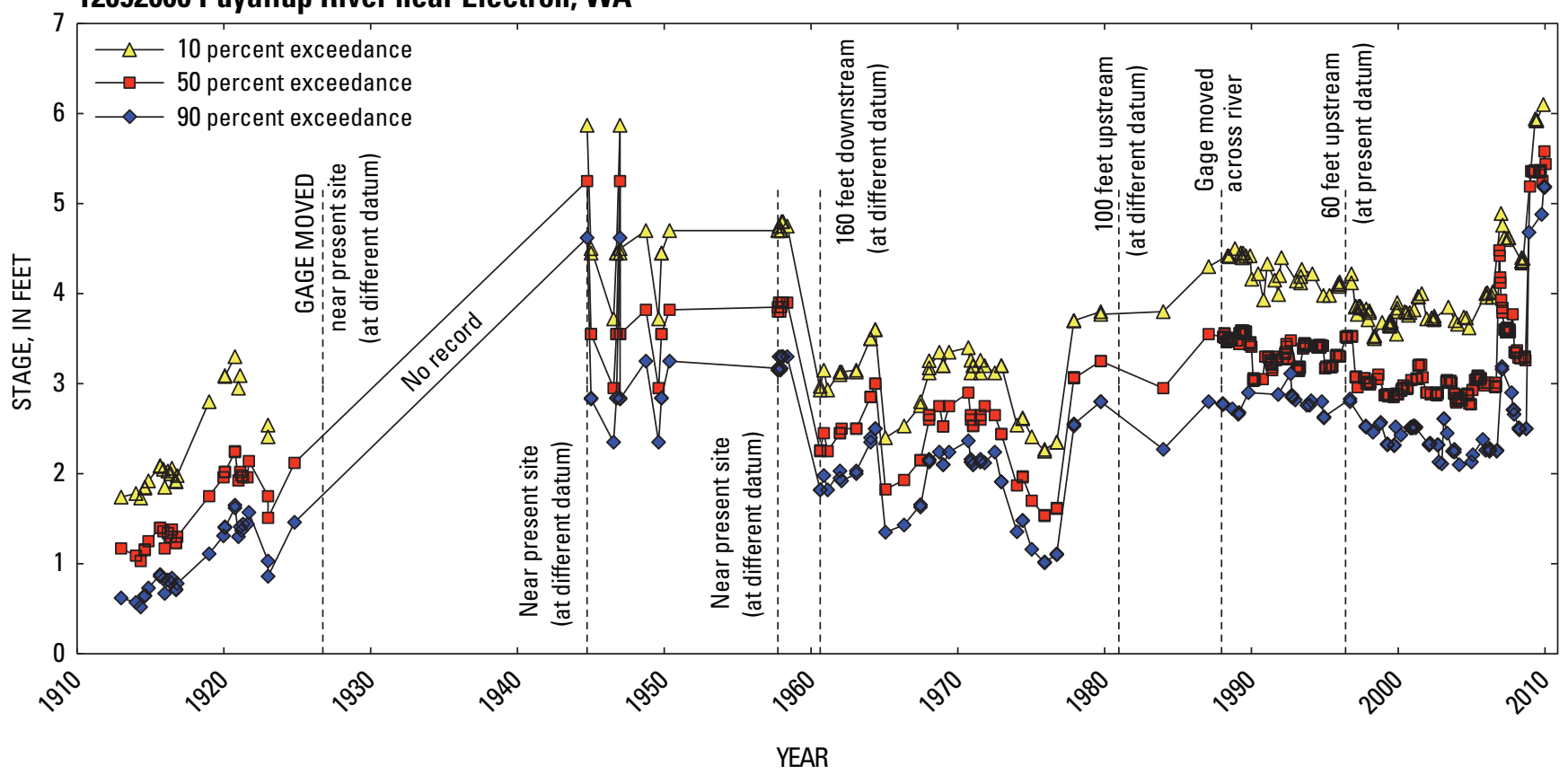

Figure 25. Stage for period of record at 10, 50, and 90 percent exceedance for gaging station 12092000, Puyallup River near Electron, Washington. 


\section{White River}

The fourth gaging station analyzed by Prych (1988) was on the White River near Sumner (12100500). Although Prych reported data from this site until 1977, only data reported during the official period of record, 1945 to 1971, were analyzed. Data analyzed for the White River near Sumner gaging station closely matched the published analysis by Prych (1988). From 1945 to 1952, the stage for a given discharge at the Sumner gaging station increased steadily by about $4 \mathrm{ft}$, followed by a $2 \mathrm{ft}$ decrease between 1953 and 1958 (fig. B1C). The stage again increased by about $2.5 \mathrm{ft}$ between 1958 and 1960 and was relatively constant through 1977.

To investigate trends on the White River since the 1980s, data from White River near Auburn (12100496) and the White River near Buckley (12098500) were analyzed. The gaging station on the White River near Auburn (as well as the discontinued gage on the White River near Sumner) is located within a natural deposition zone just downstream of White River canyon (Dunne, 1986; Herrera Environmental Consultants, 2010). Consistent with this deposition zone, stage for a given discharge at the Auburn gaging station generally has increased with a significant 2 -ft increase following prolonged peak discharge in 1996 (fig. 26). Since 1996, the site of this gaging station has challenged stream gagers with changes, fluctuations, and the problematic accumulation of cobbles and gravels. During the early 2000s, a large cobble bar built up on the left side of the river, which hydraulically isolated the stage recorder at the gaging station from the main channel during low flows. As a result of the cobble bar, lowdischarge readings from the gaging station were unreliable and the stages for the 90 percent exceedance were not reported in figure 26 after 2001. The reported elevation of higher stages, however, has been unaffected by the cobble bar and has remained accurate for median and high discharges. The overall trend in stage at median and high flow increased between 1988 and 2009 by $1.8 \mathrm{in} / \mathrm{yr}$ and $3.2 \mathrm{ft}$ overall. The USGS installed a new gaging station (station 12100490, White River at R Street near Auburn) for stage-discharge measurements about $1.3 \mathrm{mi}$ upstream of gaging station 12100496 (Auburn) and is converting the Auburn gaging station to a stage-only gage. It is anticipated that a more stable stage-discharge relation will be possible at the new gaging station site than the Auburn gaging station.

The gaging station on the White River near Buckley (12098500) was operated between 1938 and 2003. In 2003, the cableway was damaged and condemned, thereby eliminating the ability to make discharge measurements. Although net changes in stage for a given discharge at this gaging station since 1938 have been small—-there was a slight increase in stage at median flow of about $0.6 \mathrm{in} / \mathrm{yr}$ between 1987 and 2003-recorded data show infrequent, abrupt, and short-lived fluctuations of positive to negative 1-2 ft of stage since about 1970 (fig. 27). The stage for a given discharge at this gaging station oscillated $2-3 \mathrm{ft}$ in less than 5 years, and these oscillations seemed to be growing in amplitude in recent decades.

12100496 White River near Auburn, WA

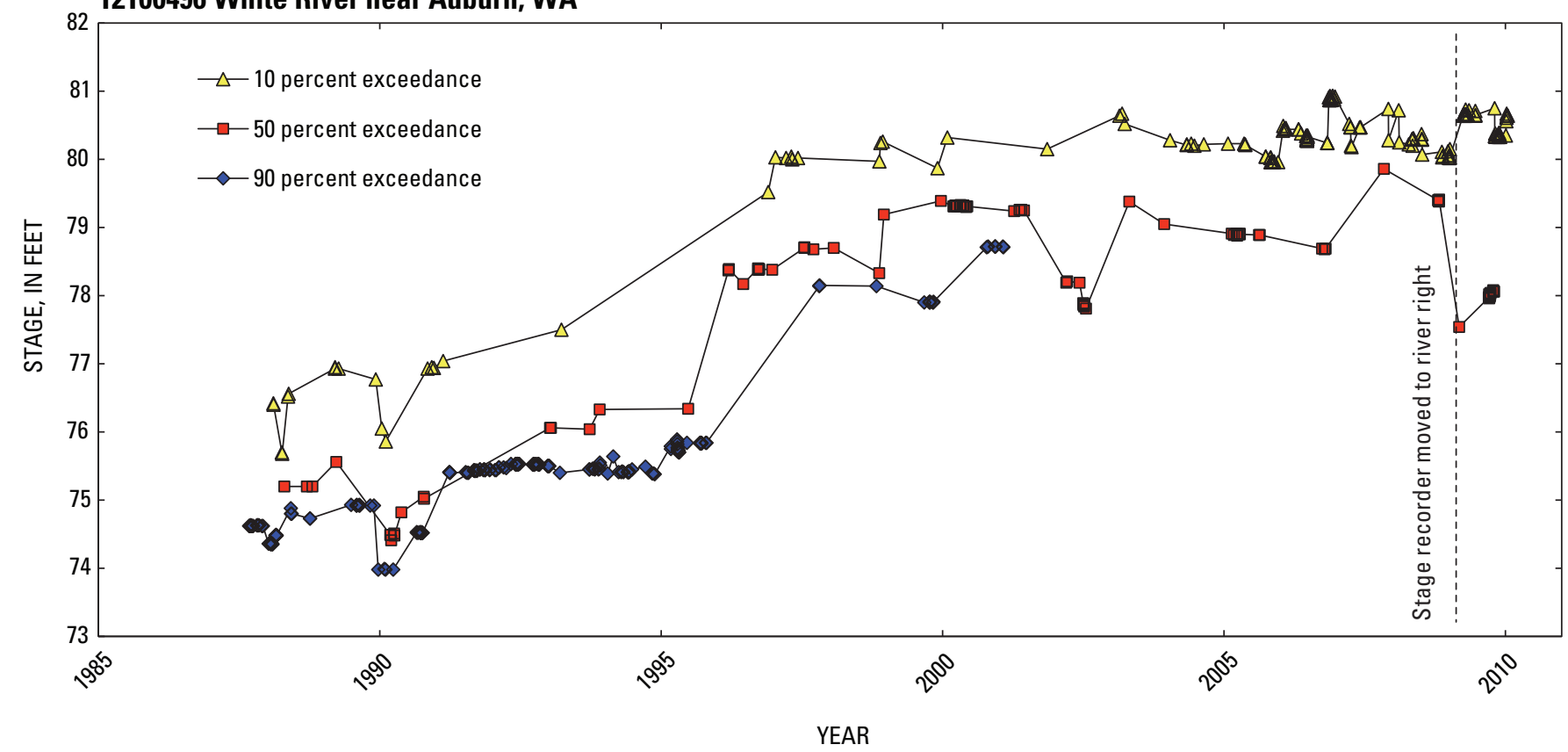

Figure 26. Stage for the period of record at 10,50, and 90 percent exceedance for gaging station 12100496, White River near Auburn, Washington. 


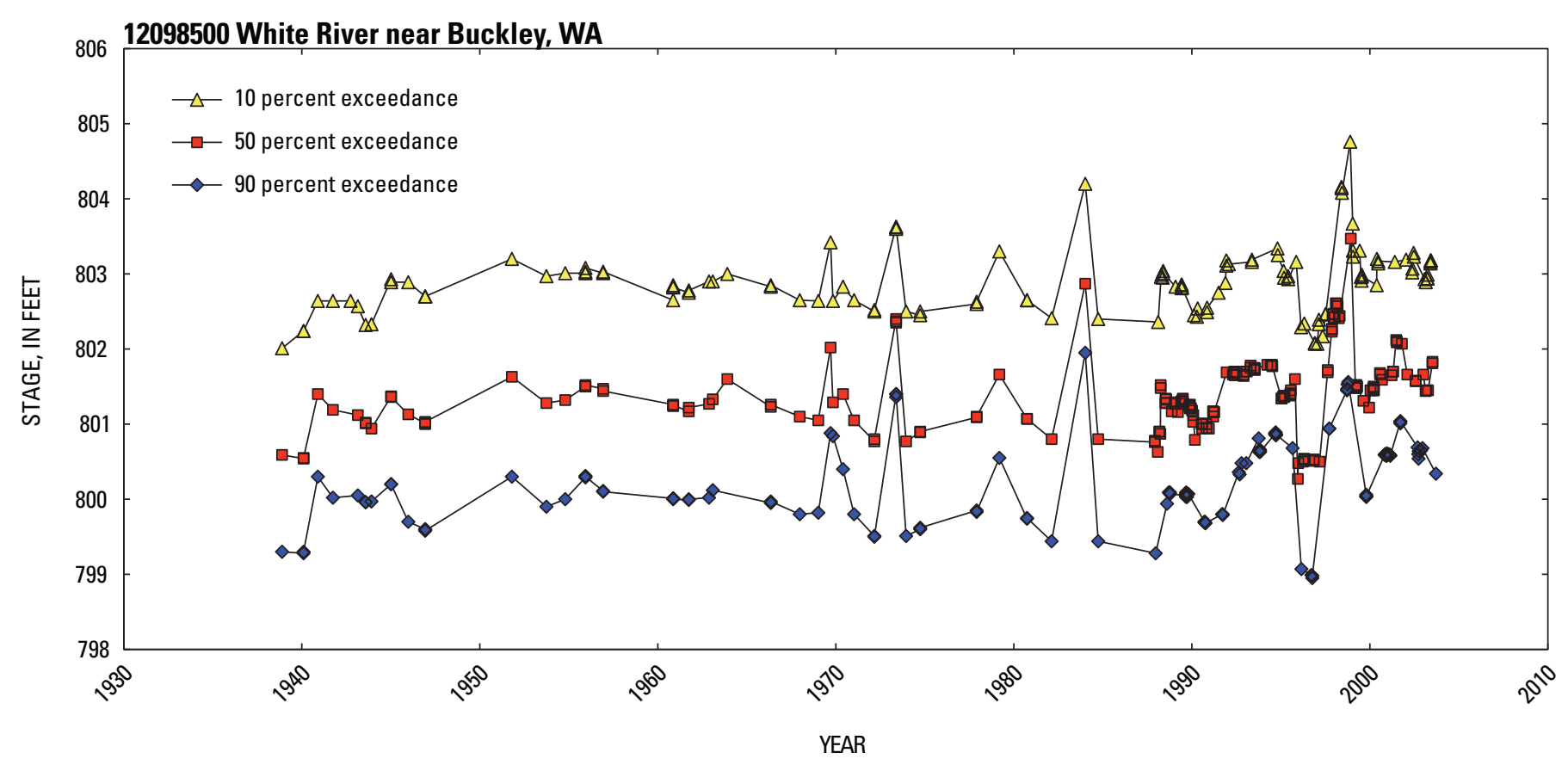

Figure 27. Stage for the period of record at 10,50, and 90 percent exceedance for gaging station 12098500, White River near Buckley, Washington.

\section{Other Glacier-Draining Rivers}

The Carbon River near Fairfax (12094000) gaging station was the final glacier-draining gaging station in the greater Puyallup River drainage basin analyzed for this study (fig. B1D). The record at Fairfax is discontinuous with two primary periods of collection: $1929-78$ and 1991-2009. Since 1991, the gage has been located at the head of a steep, narrow gorge. The variation and trends in stage at median flow for this gaging station has been relatively stable due to the bedrock hydraulic control.

The stage for a given discharge on the Nisqually River near National (12082500) has fluctuated greatly over the period of record 1942 to 2009 (fig. 28). Located about $8.5 \mathrm{mi}$ downstream of the Mount Rainier National Park boundary, these fluctuations are indicative of the close proximity to Mount Rainier and numerous large glaciers draining the southern flank of the volcano. Between 1926 and 2010, several debris flows have occurred in the park (Walder and Driedger, 1995; Copeland, 2009), and numerous large discharges have affected the Nisqually River by transporting sediment downstream. The stage at median discharge decreased about $1.5 \mathrm{ft}$ following a peak event in January 1990 and dropped $1 \mathrm{ft}$ due to high discharge in winter 1995/1996 (fig. 28). Between
1998 and 2007, the stage increased in pulses by about $4.5 \mathrm{ft}$, at a rate of increase of $5 \mathrm{in} / \mathrm{yr}$. From 2007, when the peak of record occurred, to 2010, the stage at the Nisqually River near National gaging station has decreased almost $2 \mathrm{ft}$ (fig. 28).

The stage record for a given discharge for the Cowlitz River at Packwood (14226500; fig. 1), about $11 \mathrm{mi}$ south of the Mount Rainier National Park boundary, also shows a large range of fluctuations (fig. 29) similar to Nisqually River near National. The stage increased a little more than $1 \mathrm{ft}$ from 1929 to 1940 . The stage at median discharge decreased about $0.5 \mathrm{ft}$ between 1940 and 1985. The stage then decreased about $2 \mathrm{ft}$, a rate of $1.4 \mathrm{in} / \mathrm{yr}$ (fig. 29) between 1985 and 2009. High flows in the past three decades seem to have caused incision on the Cowlitz River near Packwood, similar to trends of incision measured on the Nisqually River. During the 20th century, Cowlitz Glacier, like all large glaciers on Mount Rainier, retreated substantially (Nylen, 2004); however, Copeland (2009) reported no new debris flows in the Cowlitz River catchment of Mount Rainier since 1926. This observation suggests that the Cowlitz River at Packwood will not aggrade strongly in the near future; however, the relative contribution of sediment production from debris-flow and non-debris-flow areas in retreating glacier terrain is not well understood. 
12082500 Nisqually River near National, WA

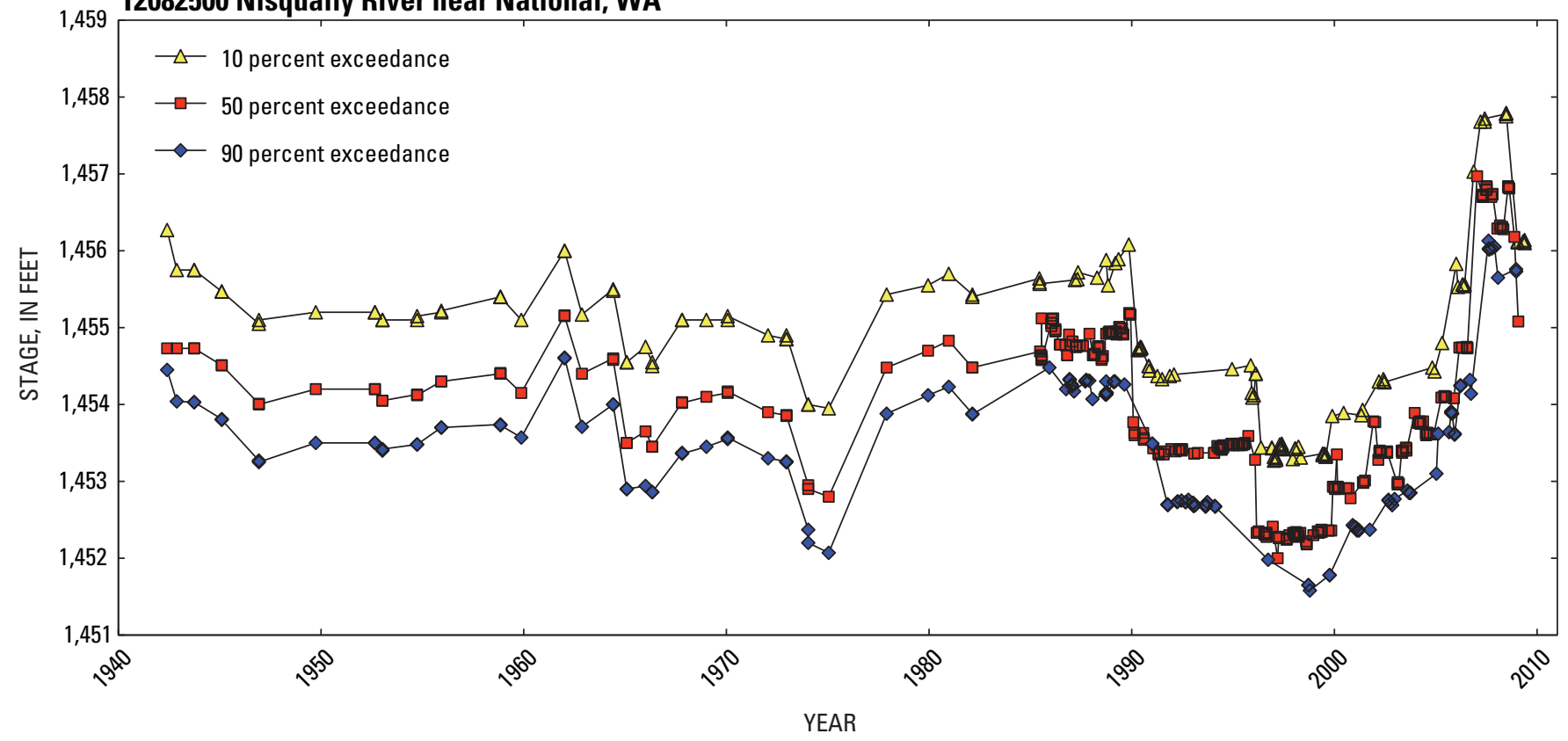

Figure 28. Stage for the period of record at 10, 50, and 90 percent exceedance for station 12082500, Nisqually River near National, Washington.

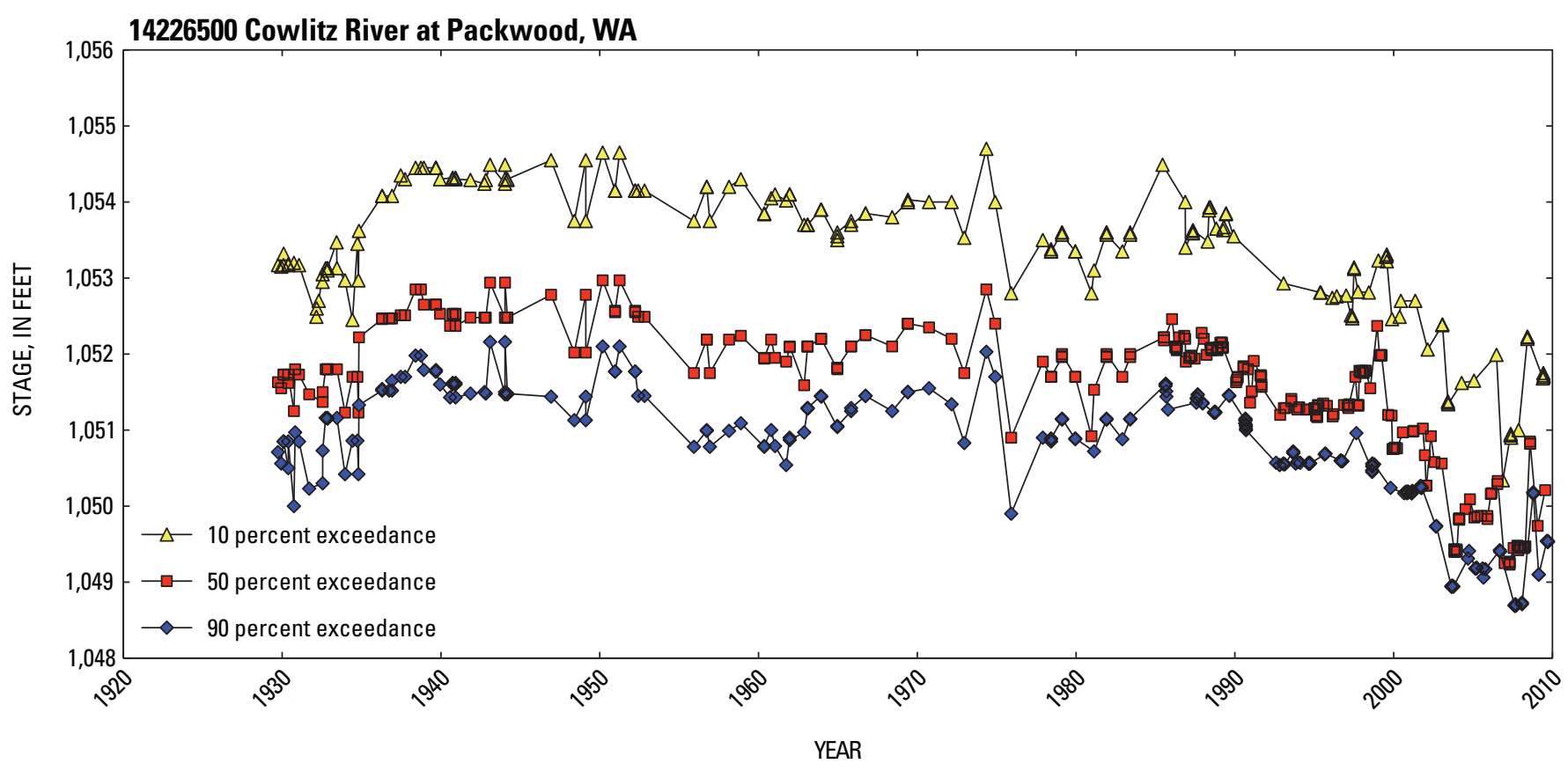

Figure 29. Stage for the period of record at 10,50, and 90 percent exceedance for gaging station 14226500, Cowlitz River at Packwood, Washington. 


\section{Other Non-Glacier-Draining Rivers}

The two gaging stations on rivers that do not directly drain Mount Rainier showed relatively stable trends in stage at median discharge. For example, the stage at Greenwater River at Greenwater (12097500; fig. 1) has been generally stable during its period of record, although there have been some fluctuations ( $\underline{\text { fig. B1E}}$ ). The stage for a given discharge periodically adjusted in a step-wise fashion in response to large peak-flow events. For example, the stage at the gaging station decreased $0.8 \mathrm{ft}$ in response to a large January 1965 peak flow and another $0.8 \mathrm{ft}$ in response to another peak flow in December 1975. In contrast, the stage at the gaging station increased $0.4 \mathrm{ft}$ following high discharge in 1996. A slight downward trend in stage was recorded between 2005 and 2009, possibly related to large discharges in 2006 and 2009. Overall, however, when compared to gaging stations on rivers that drain glaciers, the variability in stage fluctuations at the Greenwater gaging station has been small.

Similarly, the stage at median discharge at South Prairie Creek at South Prairie (12095000) has been relatively stable (fig. B1F). From 1988 to 2009, the variation in stage was less than $1.5 \mathrm{ft}$. Recently, the stage on South Prairie Creek decreased twice, about $0.5 \mathrm{ft}$ each time, following large peak discharges in November 2006 and January 2009.

\section{General Aggradation Trends Since the 1980s}

The overall trends in aggradation for the 12 gaging stations analyzed in this study are shown in table 7. Stage trends for gaging stations not discussed above are included in appendix B. Trends were analyzed for most gaging stations starting in the 1980s, but gaging stations on the Puyallup River at Alderton (12096500) and the Carbon River at Fairfax (12094000) were analyzed starting in the 1990s owing to a limited record available. Additionally, aggradation on the Nisqually River at National (12082500) was calculated only for 1998 to 2008, a period of high rates of stage increase (fig. 28). The net change in stage for the National gaging station from the 1980s to 2008 is almost zero, which masks the complex trends in stage for this site. Aggradation observed by Dunne (1986) and Prych (1988) for the White River at Sumner (12100500) from 1945 to 1947, have continued to 2010 based on trends for the White River at Auburn (12100496).

The areas of pronounced aggradation since the 1980 s were in the White River near Auburn (12100496) and the Nisqually River foot] 1989 to 1998. near National (12082500; fig. 30). Pronounced aggradation was also measured at the White River at Sumner (12100500) between 1945 and 1971. Slight aggradation was measured on the upper Puyallup River near Electron (12092000), the upper White River near Buckley (12098500), and the lower Puyallup River at Puyallup (12101500; fig. 30). Slight incision since the 1980s was detected on the Puyallup River near Orting (12093500), and pronounced incision was detected at the Cowlitz River at Packwood (14226500; table 7; fig. 30). No trend in aggradation or incision was detected at the Puyallup River at Alderton (12096500), Carbon River near Fairfax (12094000)—due to the stable hydraulic control from bedrock - and on rivers not directly draining glaciers (Greenwater River at Greenwater [12097500] and South Prairie Creek at South Prairie [12095000]).

To quantify the magnitude of fluctuations in the gaging station records, the standard deviation of each analyzed record was calculated (table 7). The greatest standard deviation of the data was for gaging stations on the Nisqually River near National (12082500), White River near Sumner (12100500), White River near Auburn (12100496), and the Cowlitz River at Packwood (14226500; table 7; fig. 31). Conversely, the standard deviation is smallest for gaging stations on the Greenwater River (12097500), Carbon River (12094000), South Prairie Creek (12095000), and lower Puyallup River (12101500). The sites with largest stage fluctuations over time were on rivers draining Mount Rainier glaciers. Proximity to Mount Rainier also tended to correlate with larger fluctuations when the gaging station was in a section of the river prone to accumulations of alluvium resulting in variable hydraulic control.

Table 7. Trends and variability of aggradation and standard deviation at the median discharge for selected streamflow-gaging stations in western Washington.

[Locations of streamflow-gaging stations are shown in figure 30. Abbreviations in/yr, inch per year; ft,

\begin{tabular}{clcrcc}
\hline $\begin{array}{c}\text { Streamflow- } \\
\text { gaging } \\
\text { station } \\
\text { No. }\end{array}$ & \multicolumn{1}{c}{ Station name } & $\begin{array}{c}\text { Aggradation } \\
\text { trends during } \\
\text { years of } \\
\text { analysis } \\
\text { (in/yr) }\end{array}$ & $\begin{array}{c}\text { Standard } \\
\text { deviation } \\
\text { (ft) }\end{array}$ & $\begin{array}{c}\text { Range } \\
\text { of years } \\
\text { analyzed }\end{array}$ \\
\hline 12101500 & Puyallup River at Puyallup & 0.3 & 0.27 & $1985-2009$ \\
12096500 & Puyallup River at Alderton & .1 & .30 & $1992-2008$ \\
12093500 & Puyallup River near Orting & -.5 & .37 & $1988-2009$ \\
12092000 & Puyallup River near Electron & .3 & .57 & $1987-2010$ \\
12100500 & White River near Sumner & 1.9 & 1.49 & $1945-1971$ \\
12100496 & White River near Auburn & 1.8 & 1.42 & $1988-2009$ \\
12098500 & White River near Buckley & .6 & .51 & $1987-2003$ \\
12094000 & Carbon River near Fairfax & .1 & .14 & $1994-2009$ \\
12082500 & Nisqually River near National & 15.0 & 1.52 & $1998-2008$ \\
14226500 & Cowlitz River at Packwood & -1.4 & .97 & $1985-2009$ \\
12097500 & Greenwater River at Greenwater & .1 & .13 & $1980-2009$ \\
12095000 & South Prairie Creek at South Prairie & -.1 & .25 & $1988-2009$ \\
\hline
\end{tabular}

${ }^{1}$ Represents rapid aggradation from 1998 to 2008; similar magnitude of incision was measured from 


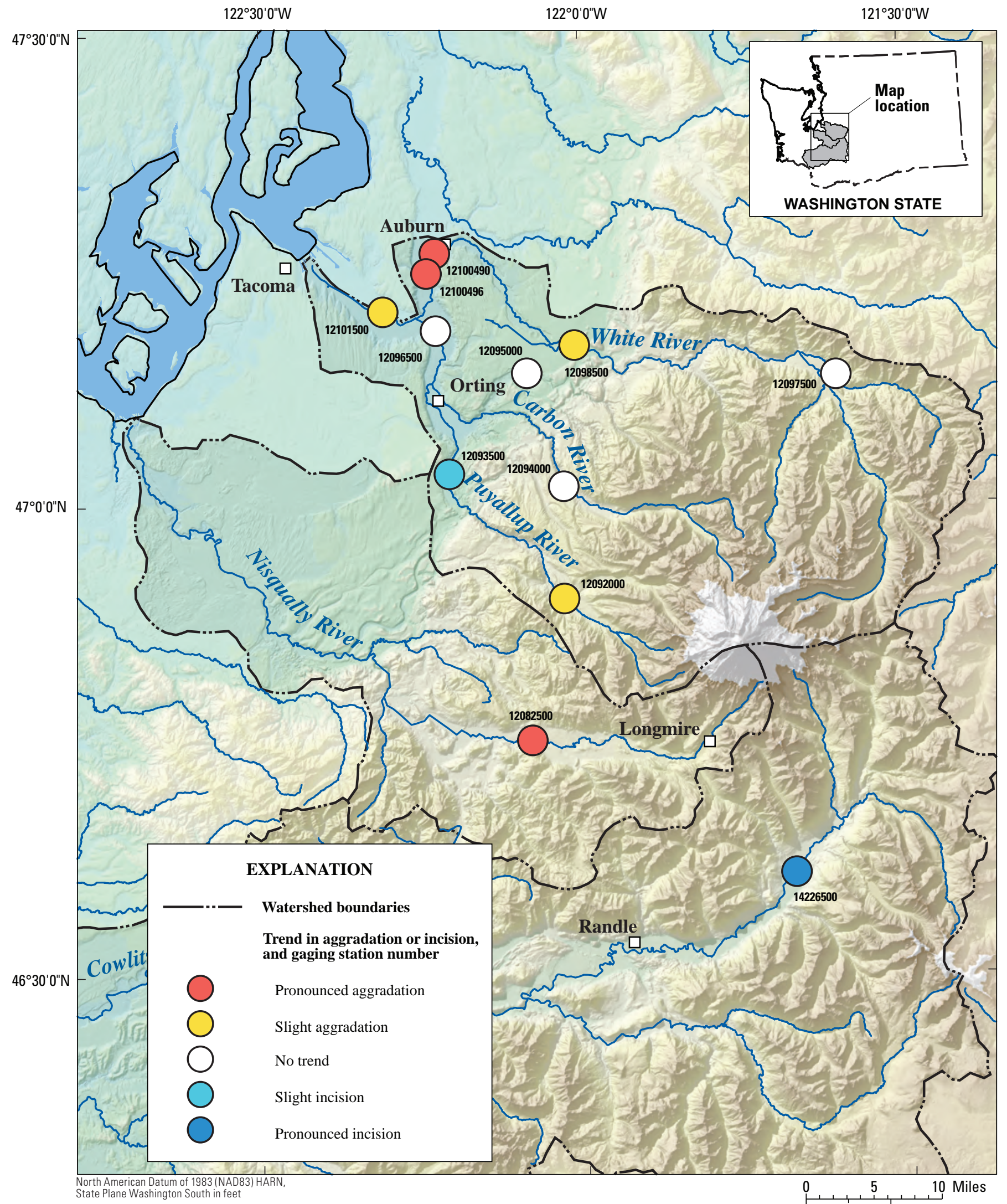

Figure 30. Trends in aggradation for 12 streamflow-gaging stations surrounding Mount Rainier primarily in the Puyallup River drainage basin, western Washington. Most trends were determined from gaging-station data recorded after 1985. 


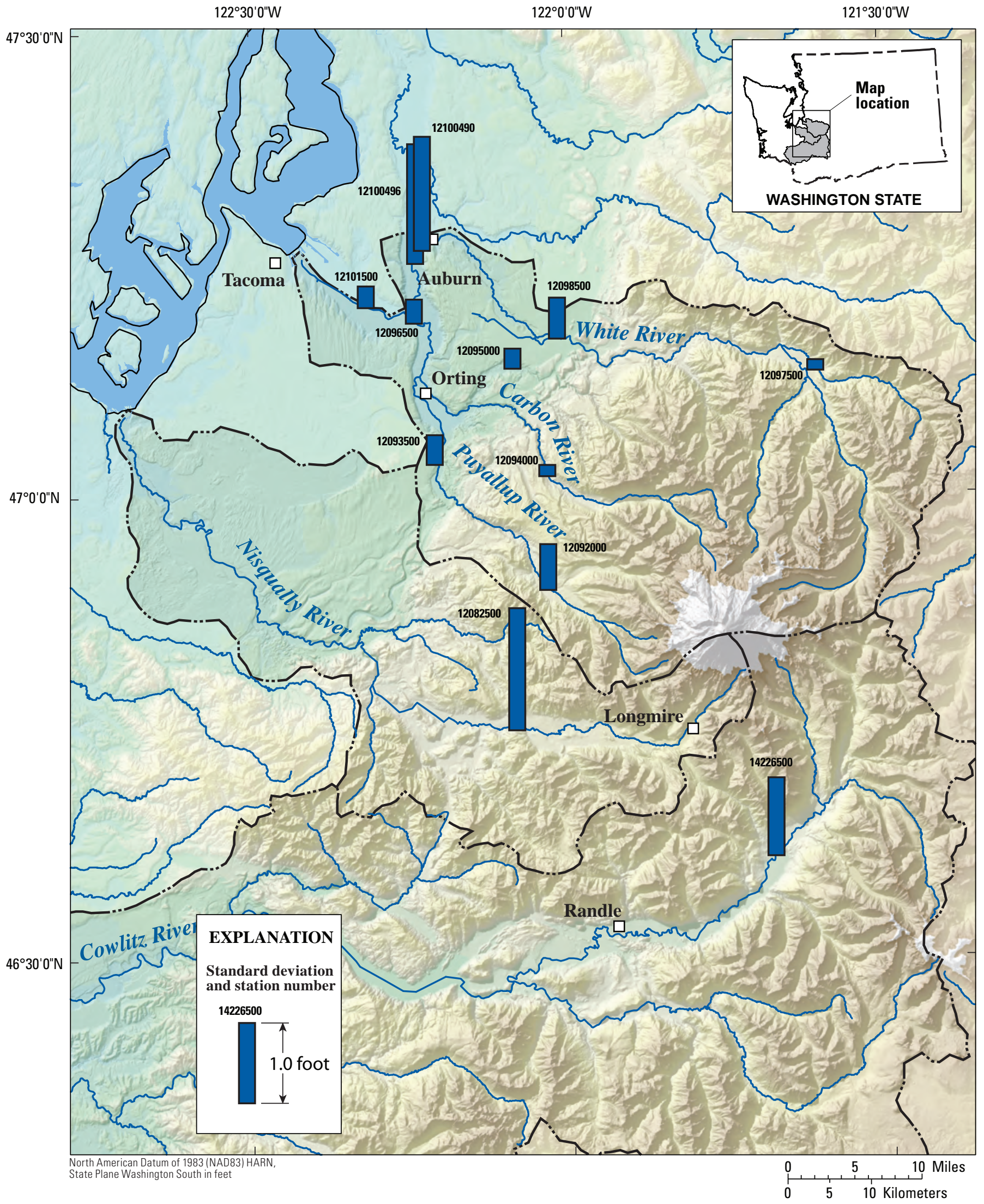

Figure 31. Standard deviation in stage at median discharge for 12 streamflow-gaging stations surrounding Mount Rainier primarily in the Puyallup River drainage basin, western Washington. Most trends were determined from gaging-station data recorded after 1985. 


\section{Theoretical Overtopping Discharge}

The theoretical overtopping discharge was estimated by analyzing changes to the stage-discharge rating curves at four USGS streamflow-gaging stations. The discharge measurements made from 1986 to 2009 are shown for each gaging station along with the theoretical overtopping discharges. The discharge measurements from 1986 to 2009 identified no change in the high-flow stage-discharge relation (resulting in no change in theoretical overtopping discharge), or a shift in the high-flow stage-discharge relation (where the theoretical overtopping discharge changed). Temporary spikes of short duration in the theoretical overtopping discharge resulted from temporary shifts to the stage-discharge rating curve.

\section{Puyallup River at Puyallup}

The nearest cross section to Puyallup River at Puyallup (12101500) was P42 (ig. A2). The left-bank elevation, $35.02 \mathrm{ft}$, was lower than the right-bank elevation and corresponded to a stage of $31.53 \mathrm{ft}$. The theoretical overtopping discharge at the gaging station decreased from about $57,800 \mathrm{ft}^{3} / \mathrm{s}$ on August 13, 1987, to a minimum of about $48,000 \mathrm{ft}^{3} / \mathrm{s}$ on January 1,1997 . The theoretical overtopping discharge then increased to $55,200 \mathrm{ft}^{3} / \mathrm{s}$ on November 17, 2009 , and finally decreased to $48,100 \mathrm{ft}^{3} / \mathrm{s}$ on November 18, 2009 (fig. 32). Since 1987, the theoretical overtopping discharge at the Puyallup gaging station has decreased by about $9,700 \mathrm{ft}^{3} / \mathrm{s}$.

\section{Puyallup River at Alderton}

The nearest cross section to Puyallup River at Alderton (12096500) was P74 (fig. A4). The right-bank elevation, $67.03 \mathrm{ft}$, was the lower of the two banks and corresponded to a stage of $63.53 \mathrm{ft}$. The theoretical overtopping discharge at the Alderton gaging station was $77,400 \mathrm{ft}^{3} / \mathrm{s}$ on November 20,1987 , and varied from a maximum of $79,300 \mathrm{ft}^{3} / \mathrm{s}$ to a minimum of $55,700 \mathrm{ft}^{3} / \mathrm{s}$ in the intervening years (fig. 33). The theoretical overtopping discharge was $68,700 \mathrm{ft}^{3} / \mathrm{s}$ on January 5, 2010 (fig. 33). From 1987 to 2010, the theoretical overtopping discharge at the Alderton gaging station decreased by about $8,700 \mathrm{ft}^{3} / \mathrm{s}$.

\section{Puyallup River near Orting}

The nearest cross section to Puyallup River near Orting (12093500) was P150-1 (fig. A7). The left-bank elevation, $371.92 \mathrm{ft}$, was the lower of the two banks and corresponded to a stage of $15.93 \mathrm{ft}$. The theoretical overtopping discharge at the Orting gaging station increased from about $35,600 \mathrm{ft}^{3} / \mathrm{s}$ to a maximum of $53,800 \mathrm{ft}^{3} / \mathrm{s}$ on October 1,1987 , then decreased to $50,700 \mathrm{ft}^{3} / \mathrm{s}$ on January 5, 2010 (fig. 34). Since 1987, the theoretical overtopping discharge at the Orting gaging station increased by about $15,100 \mathrm{ft}^{3} / \mathrm{s}$, which is consistent with incision trends at moderate discharge values (fig. 30).

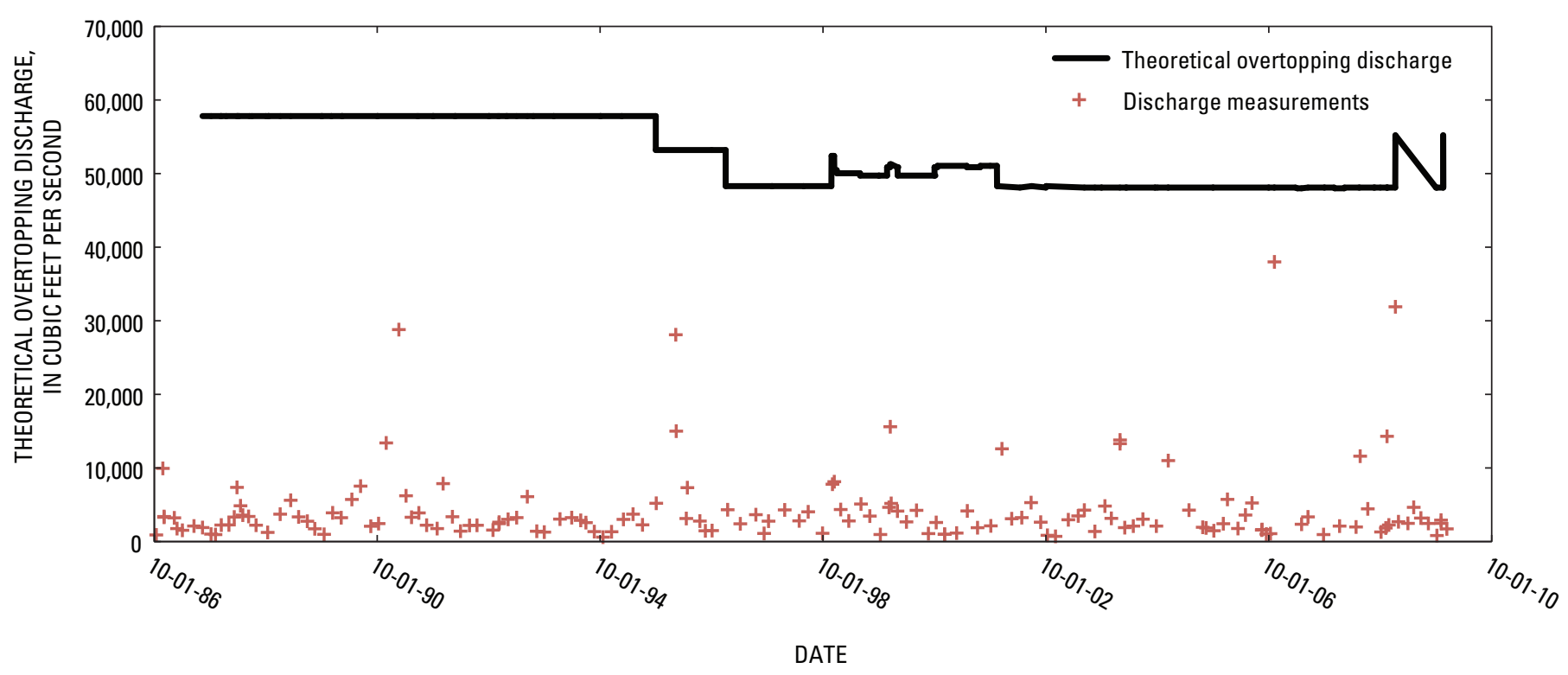

Figure 32. Long-term trends in the theoretical overtopping discharge and discharge measurements at USGS streamflow-gaging station 12101500, Puyallup River at Puyallup, Washington. 


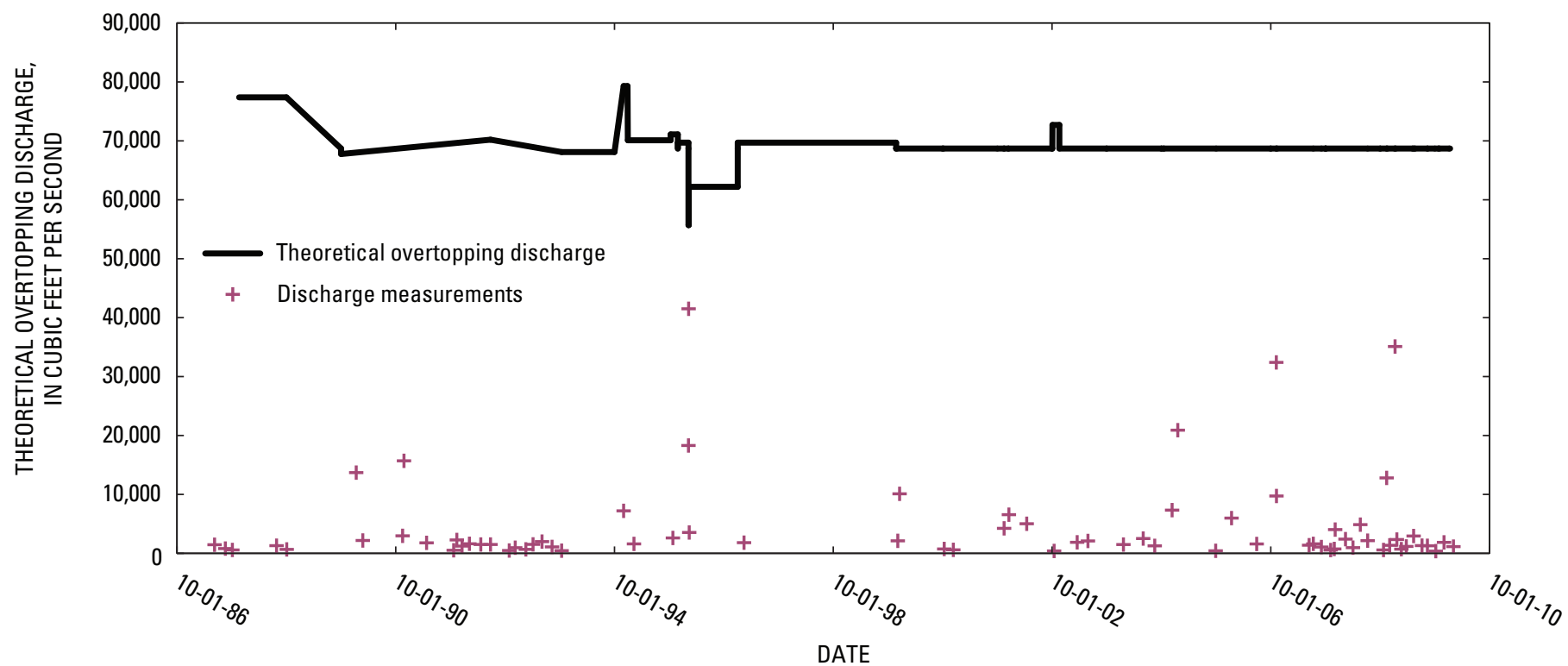

Figure 33. Long-term trends in the theoretical overtopping discharge and discharge measurements at USGS streamflow-gaging station 12096500, Puyallup River near Alderton, Washington.

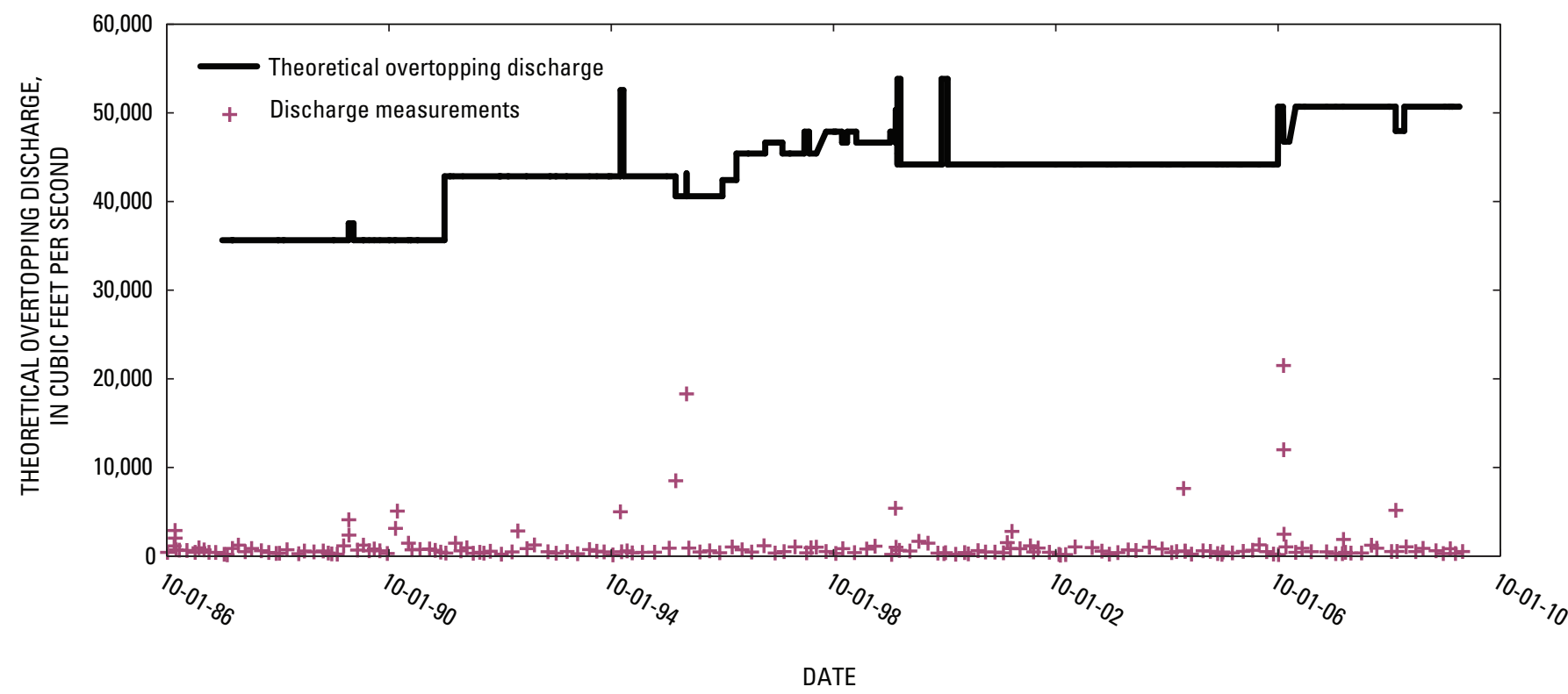

Figure 34. Long-term trends in the theoretical overtopping discharge and discharge measurements at USGS streamflow-gaging station 12093500, Puyallup River near Orting, Washington. 


\section{White River near Auburn}

The nearest cross section to White River near Auburn (12100496) was King Co. RM 6.326 (fig. A11). The right-bank elevation, $91.12 \mathrm{ft}$, was the lower of the two banks and corresponded to a stage of $87.60 \mathrm{ft}$. The theoretical overtopping discharge at the Auburn gaging station increased from about $33,800 \mathrm{ft}^{3} / \mathrm{s}$ on October 1, 1987, to a maximum of $37,300 \mathrm{ft}^{3} / \mathrm{s}$ in the early 1990s, then decreased to $14,700 \mathrm{ft}^{3} / \mathrm{s}$ on October 26, 2009 (fig. 35). Since 1987, the theoretical overtopping discharge at the Auburn gaging station has decreased by about 19,100 ft³/s. In November 2008, the channel-conveyance capacity at the Auburn gaging station was estimated to be $19,600 \mathrm{ft}^{3} / \mathrm{s}$. After January 8, 2009, the theoretical overtopping discharge was estimated to be $14,700 \mathrm{ft}^{3} / \mathrm{s}$, a decrease of $4,900 \mathrm{ft}^{3} / \mathrm{s}$, or about 25 percent.
An analysis of the water-surface elevation at 9,000 and 12,000 ft $\mathrm{t}^{3} / \mathrm{s}$ for White River near Auburn (12100496) shows the dramatic decrease in conveyance capacity in this section of the river (fig. 36). The water-surface elevations corresponding to discharges of 9,000 and 12,000 ft $\mathrm{ft}^{3} / \mathrm{s}$ were determined each time there was a shift in the upper end of the stage-discharge rating curve (fig. 36). Since 1987, the water-surface elevations corresponding to flows of 9,000 and $12,000 \mathrm{ft}^{3} / \mathrm{s}$ increased by about $5.6 \mathrm{ft}$. In November 2008, the water-surface elevations corresponding to flows of 9,000 and $12,000 \mathrm{ft}^{3} / \mathrm{s}$ at the gaging station were estimated to be 87.8 and $88.9 \mathrm{ft}$, respectively. After January 8, 2009, the water-surface elevations corresponding to a flow of 9,000 and $12,000 \mathrm{ft}^{3} / \mathrm{s}$ changed to 89.1 and $90.2 \mathrm{ft}$, respectively, an increase of $1.3 \mathrm{ft}$ over two months.

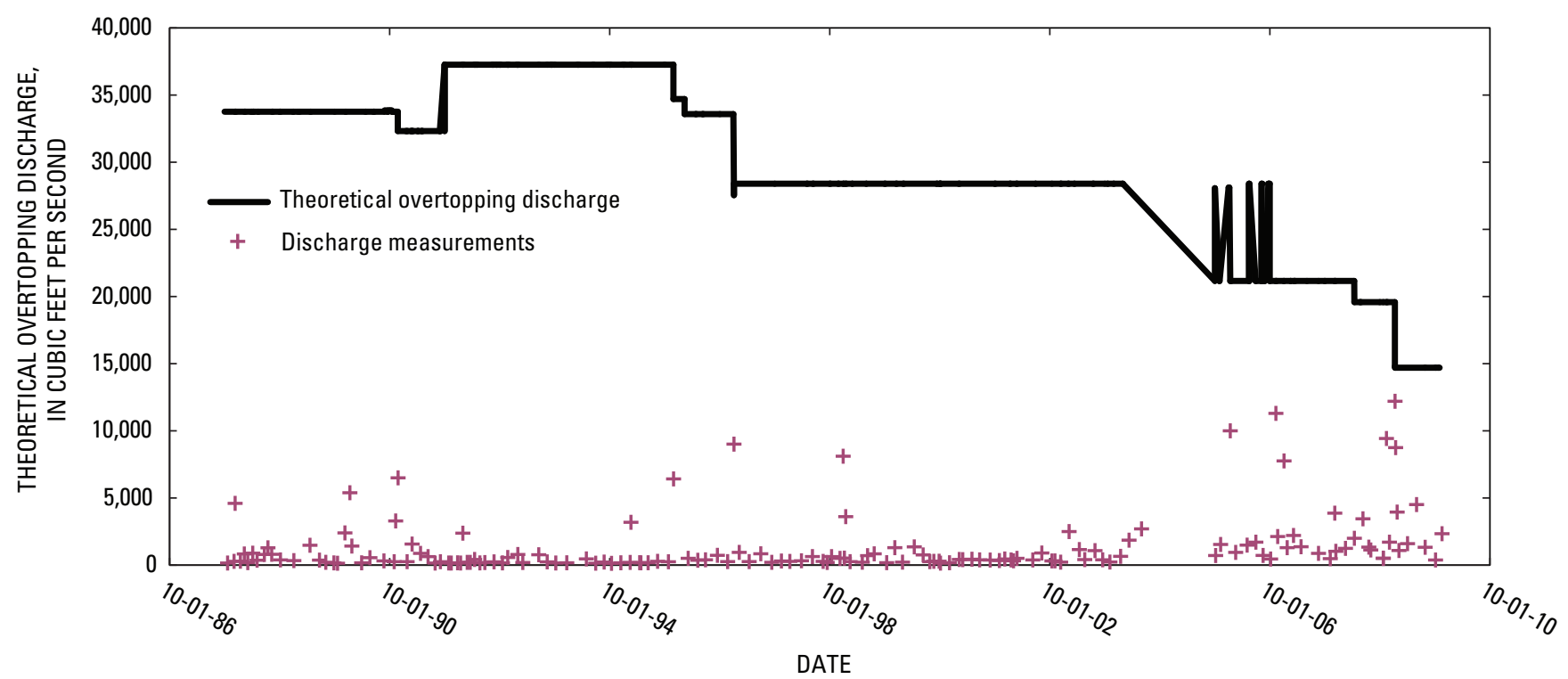

Figure 35. Long-term trends in the theoretical overtopping discharge and discharge measurements at USGS streamflow-gaging station 12100496, White River near Auburn, Washington. 


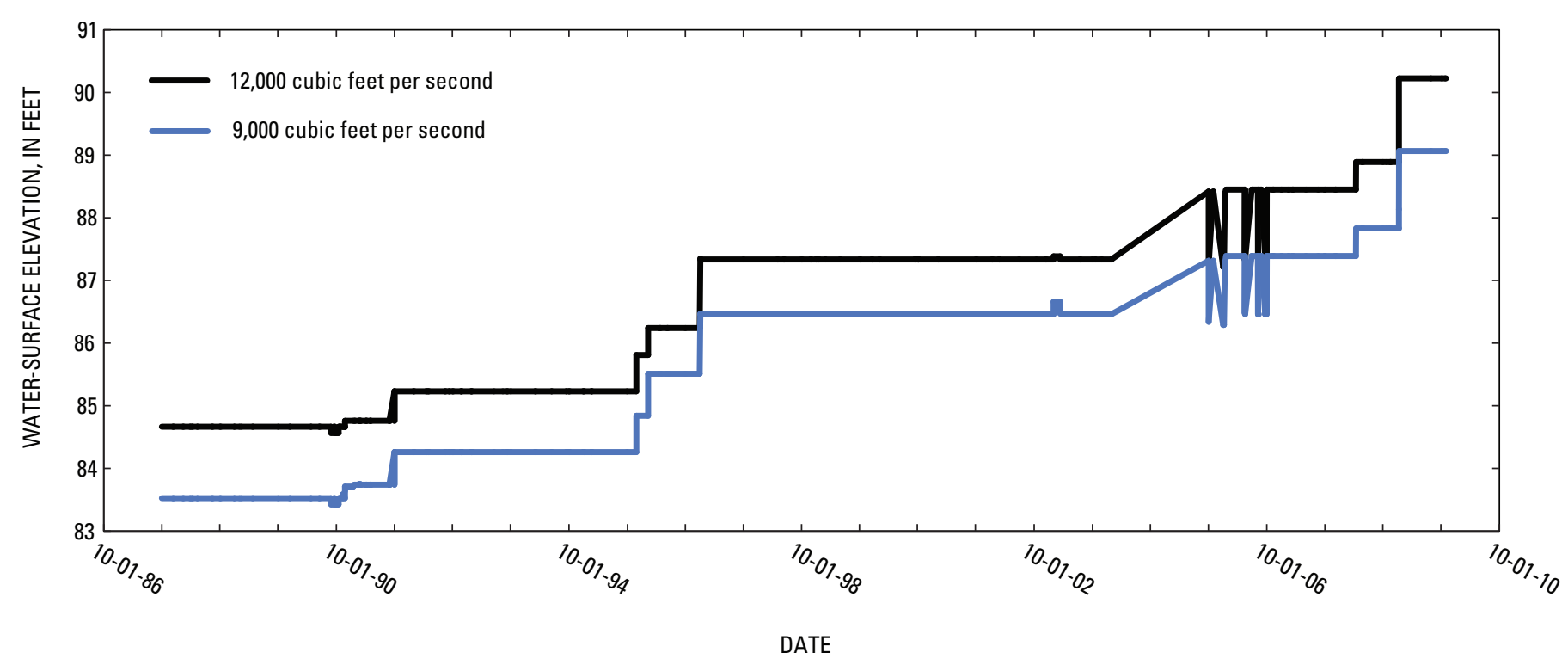

Figure 36. Long-term trends in water-surface elevations for discharges at 9,000 and 12,000 $\mathrm{ft}^{3} / \mathrm{s}$ at USGS streamflowgaging station 12100496, White River near Auburn, Washington.

\section{Flow Conveyance of the Puyallup, White, and Carbon Rivers}

Channel cross-section data measured in 2009 by the USGS and King County were used to build a hydraulic model for the Puyallup, White, and Carbon Rivers. The model underwent minimal calibration and did not include the floodplain of the river system. This model was a research tool that provided conservative estimates of water-surface elevations for specified discharges. Channel-conveyance capacity was computed for each cross section, and included a sensitivity analysis of the channel-conveyance capacity to channel roughness.

\section{Methodology}

A one-dimensional, steady-state hydraulic model, built with the Hydrologic Engineering Center River Analysis System (HEC-RAS) version 4.0 (Brunner, 2008a), was assembled for the Puyallup, White, and Carbon Rivers (fig. 1). Water-surface elevations are simulated in HEC-RAS from one cross section to the next by solving the energy and continuity equations with an iterative procedure called the standard step-backwater method (Brunner, 2008a).

The model incorporates cross-section geometry from all 156 cross sections surveyed by the USGS between June and September 2009 described previously and 50 cross sections measured by King County between February and May 2009 from RM 5 to RM 10.5 on the White River (Terry Butler, King County, written commun., 2009). Bridge information and additional cross-section geometry near bridges were obtained from the Federal Emergency Management Agency (2007) and Northwest Hydraulic Consultants Inc. (2009). The bridge cross sections extended into the floodplain and all other cross sections in the model were for channels only and did not extend into the floodplain. Obstructions were added to the bridge cross sections to remove floodplain effects from the model. River stationing and downstream flow distances were derived from the 2008 river centerline from Pierce County for all model cross sections including those measured by King County (Lorin Reinelt, Pierce County, oral commun., 2009). Ineffective flow areas (within cross sections that do not convey flow, such as deep pools and levees) were added where necessary so the model behavior agreed with field observations. Values of Manning's roughness coefficient, $n$, were selected for the channel bed based on the size and type of bed material and channel shape. Photographs of the banks at every cross section measured by the USGS during the 2009 surveys facilitated the selection of Manning's $n$ for the channel banks (Brunner, 2008a, table 3-1).

The HEC-RAS model used in this study was developed for channel-change and channel-capacity analysis. The cross sections were surveyed to high right- and left-bank points and did not extend into the floodplain. Discharge events in which flow inundates the floodplain are beyond the scope of this study; therefore, model calibration and verification were computed at flows that remained within the channel banks. 


\section{Model Calibration}

Discharges computed at USGS gaging stations throughout the basin at 12:00 PM local time on May 31, 2009, were used to calibrate the model (table 8). The discharge at the Puyallup River at Puyallup (12101500) was used for the flow in the Puyallup River between Commencement Bay and the confluence with the White River. The discharge at the Puyallup River at Alderton (12096500) was used for the flow in the Puyallup River between the confluence with the White River and the confluence with the Carbon River. The discharge at the Puyallup River near Orting (12093500) was used for the flow in the Puyallup River upstream of the confluence with the Carbon River. The discharge at the White River near Auburn (12100496) was used for the flow in the White River from the upstream extent of the model to the Lake Tapps return. The flow in the White River downstream of the Lake Tapps return was computed as the sum of the discharge at the White River near Auburn and at the Lake Tapps diversion at Dieringer (12101100). The discharge at the Carbon River near Fairfax (12094000) was used for the flow in the Carbon River upstream of the South Prairie Creek tributary. The flow in the Carbon River downstream of the South Prairie Creek tributary was computed as the sum of the discharge at the Carbon River near Fairfax and at South Prairie Creek at South Prairie. The downstream boundary condition was the tide elevation of $5.83 \mathrm{ft}$ measured at the National Oceanic and Atmospheric Administration (NOAA) tide-gage (station 9446484) in Commencement Bay near the mouth of the Puyallup River at 12:00 PM on May 31, 2009 (National Oceanic and Atmospheric Administration, 2009).

Before calibration, values of Manning's roughness coefficient, $n$, were selected for the channel bed based on the type of bed material and channel configuration and for the channel banks (Brunner, 2008a, table 3-1). Model calibration was achieved by adjusting Manning's roughness coefficients within the channel; roughness values of the channel banks were not adjusted. The only water-surface elevations available for calibration were those at gaging stations within the domain of the model. No gaging station is located on the Carbon River
Table 8. Discharges used for calibration of the one-dimensional model of the Puyallup, White, and Carbon Rivers, western Washington.

[Discharge: Measured at 12:00 PM Pacific Standard Time on May 31, 2009. Abbreviation: $\mathrm{ft}^{3} / \mathrm{s}$, cubic foot per second]

\begin{tabular}{clr}
\hline $\begin{array}{c}\text { Streamflow- } \\
\text { gaging station } \\
\text { No. }\end{array}$ & \multicolumn{1}{c}{ Station name } & $\begin{array}{c}\text { Discharge } \\
\left(\mathbf{f t}^{3} / \mathbf{s}\right)\end{array}$ \\
\hline 12101500 & Puyallup River at Puyallup & 6,820 \\
12096500 & Puyallup River at Alderton & 3,560 \\
12093500 & Puyallup River near Orting & 1,380 \\
12094000 & Carbon River near Fairfax & 1,090 \\
12095000 & South Prairie Creek at South Prairie & 318 \\
12101100 & Lake Tapps Diversion at Dieringer & 39 \\
12100496 & White River near Auburn & 4,420 \\
\hline
\end{tabular}

in the model domain, so a direct calibration in the Carbon River reach could not be made. Instead, roughness values in the Carbon River channel were selected using calibrated roughness values from morphologically similar sections of the Puyallup or White Rivers. The Manning's roughness coefficients in the basin for this model varied from 0.028 to 0.060 in the channel and from 0.033 to 0.100 along the banks. The Manning's roughness coefficients in the basin used by Northwest Hydraulic Consultants for the Federal Emergency Management Agency (2007) flood-insurance study model varied from 0.027 to 0.070 in the channel and from 0.015 to 0.150 along the banks and in the floodplain.

The difference between simulated and measured watersurface elevations at the four USGS streamflow-gaging stations in the domain of the model are shown in table 9 .

Simulated water-surface elevations were within $0.21 \mathrm{ft}$ of the values recorded at the gaging stations on the Puyallup River. The result for the White River was more problematic. The proximity of the White River gaging station to a bridge seemed to complicate calibration.

Table 9. Difference between model-simulated and measured watersurface elevations for hydrologic conditions at four gaging stations, western Washington, May 31, 2009 at 12:00 PM .

\begin{tabular}{llrrr}
\hline \multirow{2}{*}{$\begin{array}{c}\text { Streamflow- } \\
\text { gaging }\end{array}$} & Station name & \multicolumn{3}{c}{ Water-surface elevation (feet) } \\
\cline { 3 - 5 } station No. & & Measured & Simulated & Difference \\
\hline 12101500 & Puyallup River at Puyallup & 18.42 & 18.49 & 0.07 \\
12096500 & Puyallup River at Alderton & 52.13 & 52.34 & .21 \\
12093500 & Puyallup River near Orting & 361.83 & 361.70 & -.13 \\
12100496 & White River near Auburn & 86.53 & 87.45 & .92 \\
\hline
\end{tabular}




\section{Model Verification}

Model verification tests the robustness of the model by simulating flows other than those used for calibration. The hydrologic conditions in the basin on January 12, 2009 at 12:00 PM were used for model verification (table 10). The discharges at individual gaging stations were distributed throughout the model similar to the calibration simulations. The downstream boundary condition, tide elevation in Commencement Bay on January 12, 2009 at 12:00 PM, was $3.56 \mathrm{ft}$ (National Oceanic and Atmospheric Administration, 2009).
The differences between the simulated and measured water-surface elevations for the verification simulation at the four gaging stations in the domain of the model are shown in table 11.

The results of the model verification show twice the maximum error of the calibration at the Puyallup River gaging stations, but about half the error at the White River station. The differences between the simulated and measured water-surface elevations give an expected range of accuracy of the model in simulating water-surface elevations at flows of similar magnitude as the verification flows.

Table 10. Discharges used for verification of the onedimensional model of the Puyallup, White, and Carbon Rivers, western Washington.

[Discharge: Measured at 12:00 PM Pacific Standard Time on January 12, 2009. Abbreviation: $\mathrm{ft}^{3} / \mathrm{s}$, cubic foot per second]

\begin{tabular}{clr}
\hline $\begin{array}{c}\text { Streamflow- } \\
\text { gaging station } \\
\text { No. }\end{array}$ & \multicolumn{1}{c}{ Station name } & $\begin{array}{c}\text { Discharge } \\
\mathbf{f t}^{\mathbf{3}} \mathbf{/ s} \mathbf{~}\end{array}$ \\
\hline 12101500 & Puyallup River at Puyallup & 12,800 \\
12096500 & Puyallup River at Alderton & 4,420 \\
12093500 & Puyallup River near Orting & 2,030 \\
12094000 & Carbon River near Fairfax & 982 \\
12095000 & South Prairie Creek at South Prairie & 1,090 \\
12101100 & Lake Tapps Diversion at Dieringer & 2,870 \\
12100496 & White River near Auburn & 9,250 \\
\hline
\end{tabular}

Table 11. Difference between model simulated and measured water-surface elevations at four gaging stations for hydrologic conditions, western Washington, January 12, 2009 at 12:00 PM.

\begin{tabular}{clrrr}
\hline \multirow{2}{*}{$\begin{array}{c}\text { Streamflow- } \\
\text { gaging station } \\
\text { No. }\end{array}$} & Station name & \multicolumn{3}{c}{ Water-surface elevation (feet) } \\
\cline { 3 - 5 } & & Measured & Simulated & Difference \\
\hline 12101500 & Puyallup River at Puyallup & 21.47 & 21.89 & 0.42 \\
12096500 & Puyallup River at Alderton & 53.09 & 52.91 & -.19 \\
12093500 & Puyallup River near Orting & 362.38 & 362.63 & .25 \\
12100496 & White River near Auburn & 89.17 & 89.70 & .53 \\
\hline
\end{tabular}




\section{Model Comparison to Streamflow-Gaging Station Rating Curves}

To assess the accuracy of the model over a range of flows, including higher flows, a comparison was made between the simulated stage-discharge rating curves and the rating curves calculated from measurements at four gaging stations: Puyallup River at Puyallup (12101500), Puyallup River at Alderton (12096500), Puyallup River near Orting (12093500), and White River near Auburn (12100496)

(fig. 37). The discharges were normalized by the Federal Emergency Management Agency (2007) 100-year flow to allow comparison of model differences, from low to high flow, between each gaging station. The simulated results were within $2 \mathrm{ft}$ of the actual rating curves for low flows (discharge less than 40 percent of the 100-year peak) but for high discharges, the simulated results differed by up to $6 \mathrm{ft}$. The model-simulated stage-discharge rating curves compared most closely to the actual rating curves at White River near Auburn and Puyallup River near Orting and least closely to the actual rating curves at Puyallup River at Puyallup and Puyallup River at Alderton gaging stations.
A channel-only hydraulic model is only accurate at a cross section when the flow in the model everywhere downstream of that cross section is within the channel. The channel-only hydraulic model artificially confines flow within the channel when the flow is greater than the channel-conveyance capacity and artificially increases the water-surface elevation that would otherwise overtop the bank and inundate the floodplain. As discussed previously, water-surface elevations are controlled from downstream; therefore, an artificial increase in water-surface elevation at a cross section propagates an erroneous high water-surface elevation upstream. If the simulated flow is artificially confined downstream, the upstream computed water-surface elevation will be artificially elevated for the simulated flow and computed channel-conveyance capacity will be less than the actual capacity. The water-surface elevation becomes more erroneous as the flow is artificially confined in more cross sections downstream because the error in water-surface elevation at each cross section compounds the errors of those downstream. The channel-only hydraulic modeling approach to estimating channel-conveyance capacity is therefore inherently conservative when the flow is artificially confined at increasingly larger discharges, meaning the computed values are less than the actual values.

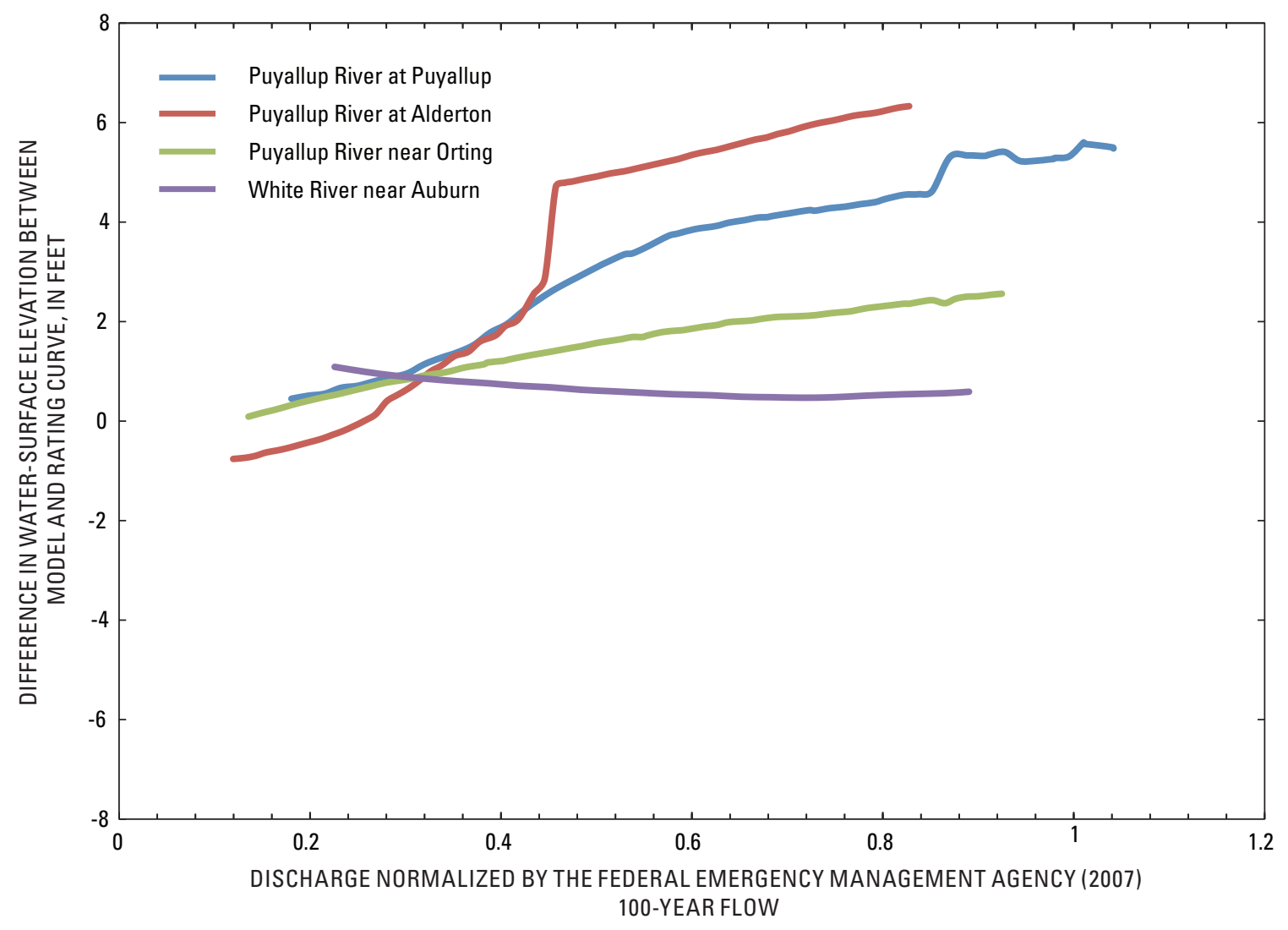

Figure 37. Normalized discharge and difference in water-surface elevation between modelsimulated rating curves at nearby cross sections and rating curves calculated from measurements at four USGS streamflow-gaging stations in the Puyallup and White Rivers, western Washington. Positive values indicate the simulated water-surface elevations were higher than the measured water-surface elevations. 
An accurate calibration of the roughness at high flow was not possible for this study due to limitations of the modeling approach. The channel-only hydraulic model artificially raises the water-surface elevations once the channel-conveyance capacity of a cross section downstream has been reached and to estimate high-flow water-surface elevations accurately, the roughness in the model has to be unrealistically reduced. For instance, when the roughness values in the lower Puyallup River were reduced to try to minimize the difference between the simulated and measured rating curves at gaging station 12101500, Puyallup River at Puyallup, the Manning's $n$-values were 0.015 , an unrealistic value for this channel segment (Brunner, 2008a, table 3-1). Roughness values in channels typically decrease with increasing stage as the ratio of the size of the roughness element on the bed to the water depth decreases (Limerinos, 1970; Jarrett, 1984); however, not to the extent necessary to reduce the error at Puyallup River at Puyallup. Roughness values for this model were kept constant for all discharge values, which could explain some, but not all of the over-prediction of stage at high flows. The roughness values within the hydraulic model are consistent throughout the study area (vegetation, bed material, and channel-shape characteristics). Despite model uncertainty and limitations, the internal consistency of the model provides channel-conveyance capacity estimates throughout the lower Puyallup River system that identify locations with low conveyance capacity.

\section{Channel-Conveyance Capacity}

Channel-conveyance capacity is a useful tool for river managers to identify reaches susceptible to flooding. The quality of a channel-conveyance capacity estimate is affected by numerous factors including, but not limited to, the distribution of channel cross sections which determines how representative the model geometry is of the larger river system as a whole and whether the model captures all of the major limiting hydraulic features, such as channel constrictions, locally higher bed elevations (that is, riffles or gravel bars), and low points in levee elevations. The antecedent flow condition and sediment load determines the current state of the channel bed through sediment deposition or erosion. The time when the channel cross sections are surveyed affects the resulting bed geometry. Once the river geometry has been surveyed, the channel and bank roughness are calibrated within published values for bed-material and vegetation type using known water-surface elevations at various flows. The spatial density of the water-surface elevations and the steadiness of the flow used for the calibration affect the overall quality of the model simulation results. Because roughness generally decreases as the flow increases, accounting for this in the model by calibrating to a range of flows improves model simulation results over a range of flows. Finally, when determining the channel-conveyance capacity, the bank elevation defining the channel extent must be determined; this may vary between different studies estimating channel-conveyance capacity. These factors complicate the accuracy of the channel-conveyance capacity estimates and could account for some of the discrepancy between those computed by the U.S. Army Corps of Engineers (2009) and this study. The difference between the channel-conveyance capacity estimates by Prych (1988) and this study could be partially attributed to the factors noted above, but most likely are attributed primarily to changes in bed elevation, with vegetation changes as a minor contributor.

The HEC-RAS model, calibrated and verified as described above, was used to estimate the channelconveyance capacity at each cross section surveyed in 2009. The channel-conveyance capacity is defined as the discharge for which the water-surface elevation equals the top of the river bank. The channel-conveyance capacity estimates do not represent the flooding of roads, buildings, and other infrastructure. When the channel-conveyance capacity estimate is unusually low compared to upstream and downstream cross sections, the channel-conveyance capacity estimate may be based on a locally low channel bank point, where the model did not extend far out into the adjacent low floodplain, and does not indicate the flooding of structures.

Prych (1988) determined recurrence-interval peak flows for the Puyallup, White, and Carbon Rivers when the Puyallup River was peaking and also recurrence-interval peak flows for the Puyallup, White, and Carbon Rivers when the White River was peaking. The same flow scenarios simulated by Prych (1988) were used to determine channel-conveyance capacity in 2009 at each cross section using the new model (tables 2 and $\underline{3}$ ) with additional simulated discharge values at $500 \mathrm{ft}^{3} / \mathrm{s}$ increments to improve simulation resolution. Using Prych's (1988) flows provided a direct comparison to how the channel-conveyance capacity has changed over the last 25 years. The downstream boundary condition for this analysis was mean higher-high water (MHHW) (9.34 ft) in Commencement Bay (National Oceanic and Atmospheric Administration, 2009).

This analysis assumes that the levees would not fail during high flows (they can only be overtopped in the model) and the flow in the channels would not be restricted by debris. When flow overtops the banks of the channel in the model, the flow is artificially constrained by the boundary of the model and not allowed to inundate the floodplain (Brunner, 2008a), thus providing a conservative estimate of channel-conveyance capacity.

The channel-conveyance capacity was computed for the left and right banks (defined looking downstream) at each cross section for the Puyallup, White, and Carbon Rivers (table C1). The channel-conveyance capacity was computed for each cross-section location at the top of the bank and $3 \mathrm{ft}$ below the top of bank, whether a levee was present or not (table C1). 
The channel-conveyance capacity computed for the lower of the left- or right-bank elevation on the Puyallup, White, and Carbon Rivers was compared to the capacity computed by Prych (1988). When the channel-conveyance capacity was greater than the simulated 100-year flow for either 1984 or 2009, the channel-conveyance capacity was reported as the simulated 100-year flow of Prych (1988).

\section{Puyallup River}

The 2009 channel-conveyance capacity is smallest in the lower Puyallup River just downstream of its confluence with the White River (fig. 2; fig. 38). Between the mouth of the Puyallup River and RM 4, the channel-conveyance capacity is at least $50,000 \mathrm{ft}^{3} / \mathrm{s}$. Between RM 4 and the confluence with the White River, the channel-conveyance capacity varies between about 30,000 and $50,000 \mathrm{ft}^{3} / \mathrm{s}$. The channel-conveyance capacity of the right bank of the cross section at the river mouth at Commencement Bay was not computed because the right bank was on the downstream slope of the levee.
Compared to 1984 (Prych, 1988), the channelconveyance capacity of the lower Puyallup River has not changed to less than $50,000 \mathrm{ft}^{3} / \mathrm{s}$ between the river mouth and about RM 4. Between RM 4 and the confluence with the White River, channel-conveyance capacity increased and decreased since 1984 with no predominant spatial trend.

The 2009 channel-conveyance capacity of the middle Puyallup River generally varies between about 36,000 and $20,000 \mathrm{ft}^{3} / \mathrm{s}$, with a reach average of $25,000 \mathrm{ft}^{3} / \mathrm{s}$. The smallest capacity is $14,000 \mathrm{ft}^{3} / \mathrm{s}$, just upstream of the confluence with the White River (fig 2; fig. 39).

Compared to 1984, the channel-conveyance capacity of the middle Puyallup River has increased and decreased throughout the reach, but the overall spatial trends in capacity in 2009 were similar to those reported by Prych (1988). The 2009 and 1984 channel-conveyance capacity estimates for the middle Puyallup River show lower capacity near the confluence with the White River and between RM 12.5-16.5 and higher capacity near RM 12 and RM 17. Due to the uncertainty in individual estimates of channelconveyance capacity, there seems to be no discernible change in channel-conveyance capacity of the middle Puyallup River since 1984.

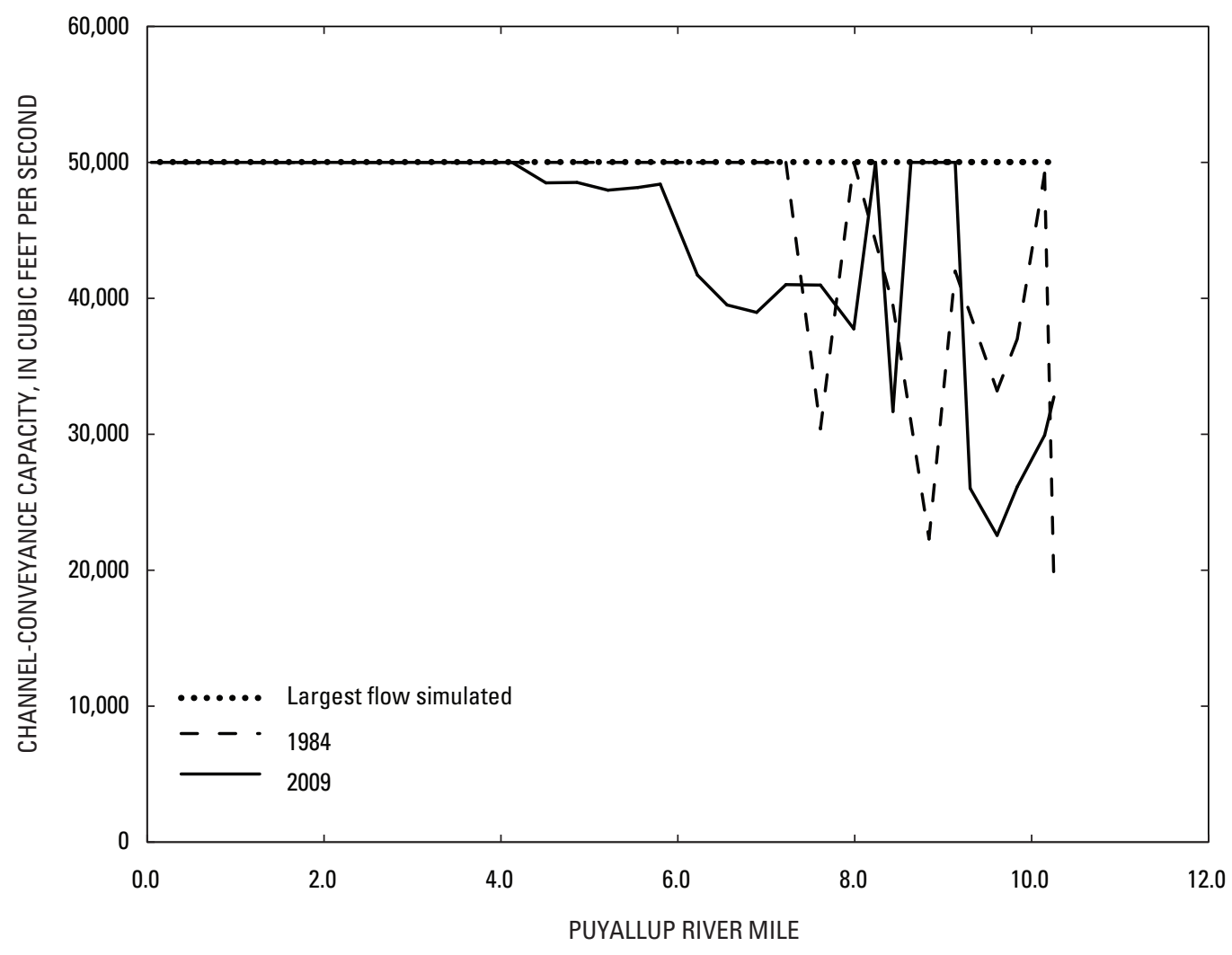

Figure 38. Simulated channel-conveyance capacity for the lower Puyallup River, western Washington, 1984 and 2009. 


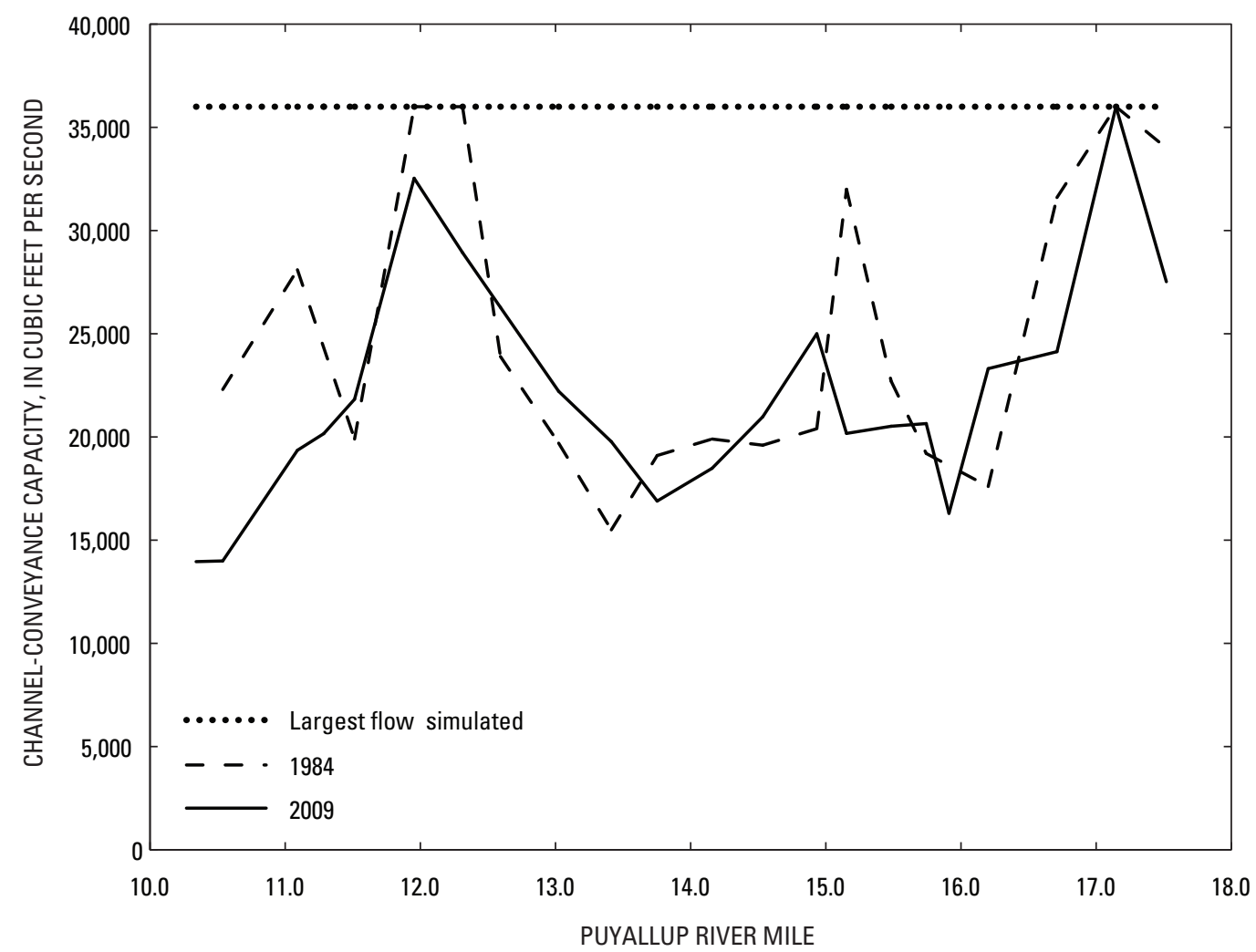

Figure 39. Simulated channel-conveyance capacity for the middle Puyallup River, western Washington, 1984 and 2009.

The 2009 channel-conveyance capacity of the upper Puyallup River is a minimum of about $8,000 \mathrm{ft}^{3} / \mathrm{s}$ at RM 20 in the lower half of the reach (fig. 40). Between the Carbon River and RM 22, the channel-conveyance capacity generally varied between about 9,000 and $17,000 \mathrm{ft}^{3} / \mathrm{s}$. Upstream of RM 22 to the upper boundary of the model (RM 28.9), channelconveyance capacity is at least $17,000 \mathrm{ft}^{3} / \mathrm{s}$ except at two cross sections that had low-elevation banks.

Compared to 1984 (Prych, 1988), the channelconveyance capacity generally decreased by as much as $9,000 \mathrm{ft}^{3} / \mathrm{s}$ between RM 21.5 and RM 19.5. Between RM 23.3 and RM 21.8, channel-conveyance capacity has improved significantly, probably in response to the completion of the Soldiers' Home setback-levee project at this location in 2007. Upstream of RM 24 (to RM 26 where comparisons can be made), in the Ford setback reach, the estimate of channel-conveyance capacity has not changed detectably since 1984 because the estimate of channel-conveyance capacity in 1984 and in 2009 was greater than the 100-year flow and this approach does not discern channel-conveyance changes greater than the 100-year flow. The two low spikes upstream of RM 25 are due to low bank points within a forested floodplain.

\section{White River}

The 2009 channel-conveyance capacity of the White River decreased from its mouth to a minimum value of about 4,200 ft $3 / \mathrm{s}$ at RM 5.7 (fig. 41). Between RM 7 and the upstream extent of the model (RM 10.5), channel-conveyance capacity is at least $19,000 \mathrm{ft}^{3} / \mathrm{s}$ with one exception at RM 7.5.

Compared to 1984 (Prych, 1988), the relative spatial trends in capacity were similar, but the magnitude of channel-conveyance capacity decreased significantly between RM 0.0 and RM 7.0. For the lower $2 \mathrm{mi}$ of the White River (near the confluence with the Puyallup River), the 1984 channel-conveyance capacity was calculated based on backwater from the Puyallup River (Prych, 1988). Between about RM 2 and RM 7, channel-conveyance capacity decreased by $7,000 \mathrm{ft}^{3} / \mathrm{s}$ on average since 1984 , or by about 20-50 percent. According to the U.S. Army Corps of Engineers (2009), flows in the range of about 5,000 to $9,000 \mathrm{ft}^{3} / \mathrm{s}$ that exceed the channel-conveyance capacity inundate only vegetated areas; flows greater than $9,000 \mathrm{ft}^{3} / \mathrm{s}$ could flood homes. Between RM 7 and the upstream extent of the comparison (RM 10.5), the channel-conveyance capacity was 19,000 ft $3 / \mathrm{s}$ in 1984 and 2009 with no detectable change. 


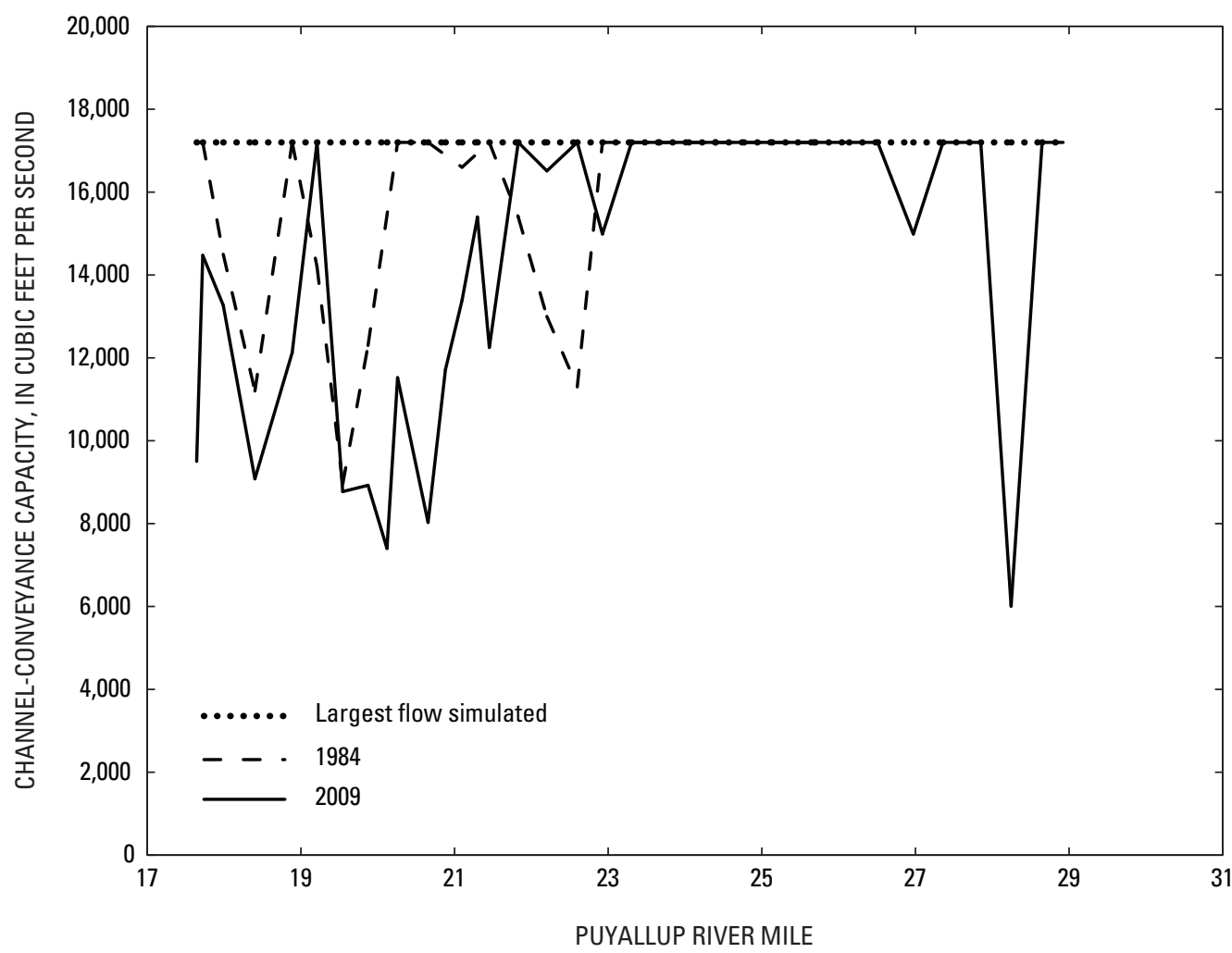

Figure 40. Simulated channel-conveyance capacity for the upper Puyallup River, western Washington, 1984 and 2009.

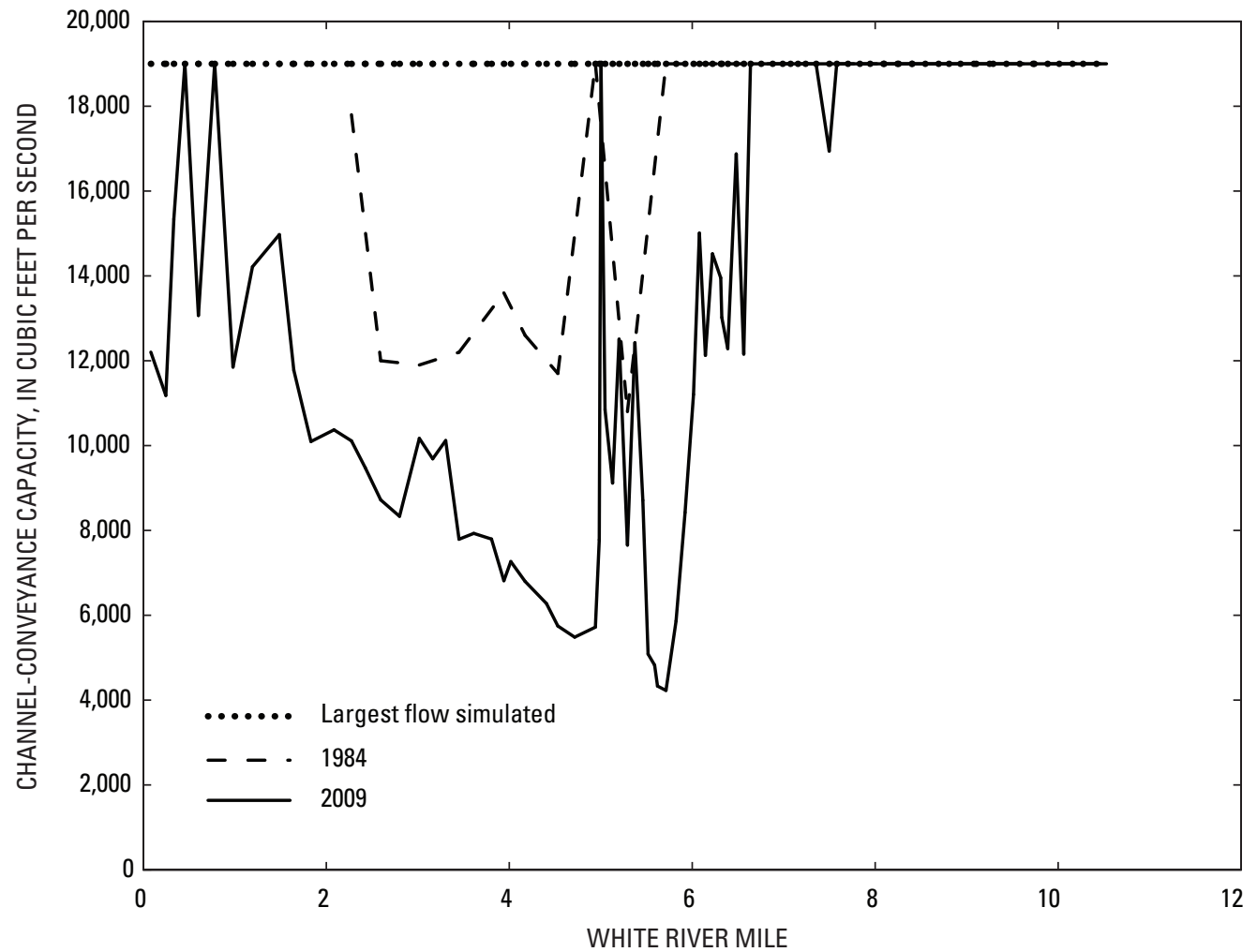

Figure 41. Simulated channel-conveyance capacity for the White River, western Washington, 1984 and 2009. 


\section{Carbon River}

The 2009 channel-conveyance capacity of the Carbon River is lowest near its confluence with the Puyallup River (fig. 42); South Prairie Creek enters the Carbon River at RM 5.8 where the simulated flow changes the most. Upstream of the Puyallup River, the channel-conveyance capacity of the Carbon River is predominantly at the largest-simulated flow with the exception of four cross sections where capacity is notably smaller. Most of the right bank of the Carbon River is bounded by a bluff or a forested floodplain backed by a bluff. When channel-conveyance capacity at the right bank of the Carbon River was less than the highest flow simulated at these four cross sections, the right bank was within the lower forested floodplain.

Compared to 1984 (Prych, 1988), the channel-conveyance capacity of the Carbon River changed little. Between RM 0.5 and RM 1.5, the channel-conveyance capacity increased, on average, by about $4,000 \mathrm{ft}^{3} / \mathrm{s}$ since 1984 (fig. 42). Changes in capacity upstream of RM 1.5 are due to the selection of the top of bank in the lower floodplain rather than the setback bluff. Prych (1988) did not model the Carbon River upstream of RM 5.9.

\section{Comparison of Hydraulic Models}

Prych (1988) estimated channel-conveyance capacity using a channel-only hydraulic model and did not fully document model roughness values, errors in calibrating the model, or uncertainty in the individual estimates of the channel-conveyance capacity. The locations where the average channel elevation has increased within confined channels between 1984 and 2009 corresponded to decreases in channel-conveyance capacity between 1984 and 2009, which indicates that the models are comparable despite the uncertainties of the individual estimates.

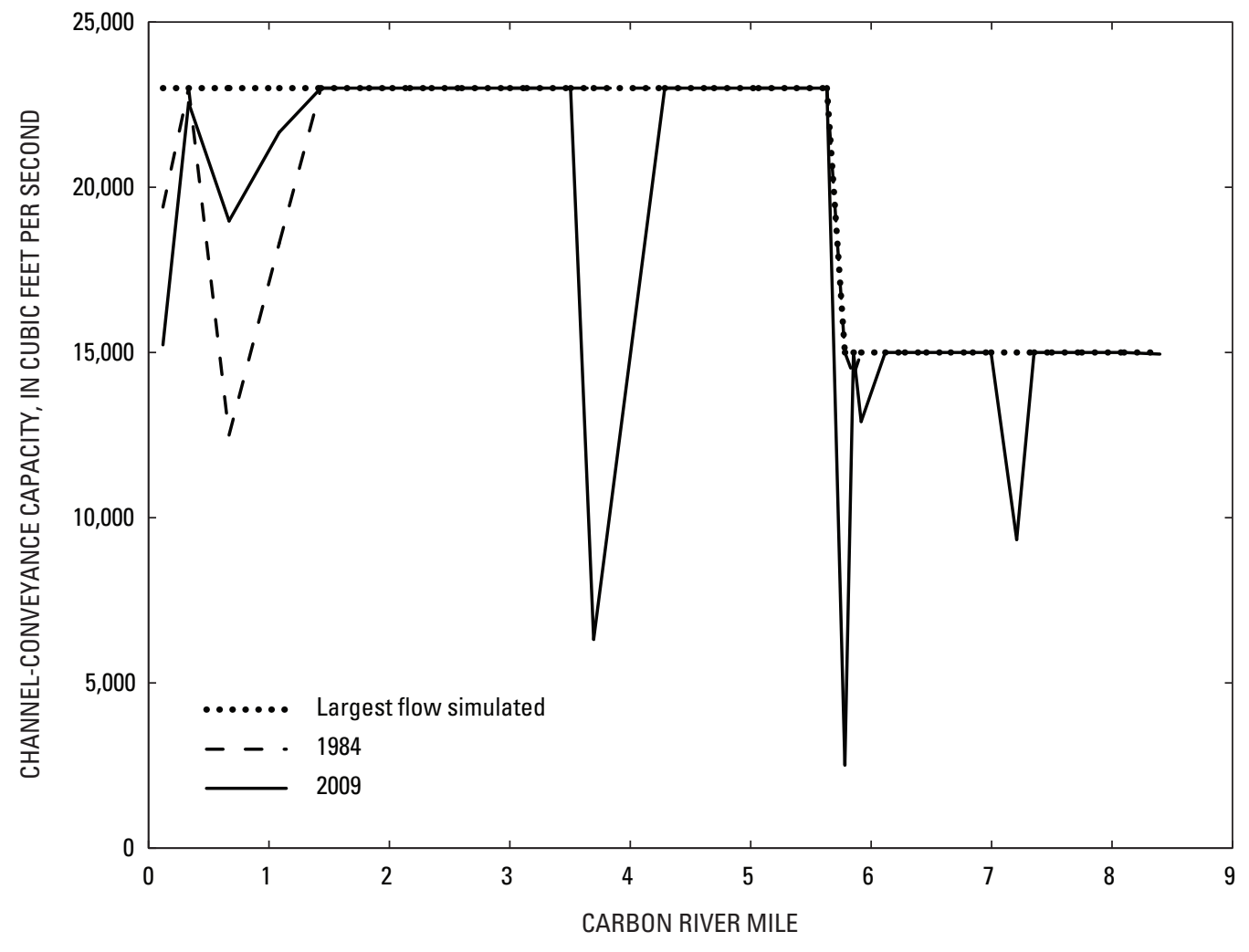

Figure 42. Simulated channel-conveyance capacity for the Carbon River, western Washington, 1984 and 2009. 


\section{Model Sensitivity to Roughness}

The sensitivity of 100-year recurrence-interval watersurface elevations to changes in channel and bank roughness was analyzed by changing Manning's roughness coefficient in the channel and along the bank separately by \pm 10 percent. The water-surface elevations of the 100-year recurrence-interval flows (Prych, 1988) were calculated for each variation in roughness and the difference from the baseline condition was computed.

For most of the length of the Puyallup River, the water-surface elevation of the 100-year flow changes by less than about $\pm 1.5 \mathrm{ft}$ from a 10 percent increase or decrease in the bank or channel roughness (fig. 43). The model exhibited higher sensitivity to changes in channel roughness downstream of RM 7, probably due to the higher overall channel conveyance and smaller slope. Upstream of RM 7, the model sensitivity to channel roughness shows a decreasing spatial trend probably resulting from progressively higher slopes. The model showed almost no sensitivity to changing bank roughness downstream of RM 4, because the banks are fairly steep and represent a small part of the cross section. Between RM 22 and RM 4, the model exhibited stronger sensitivity to bank roughness because the vegetation along the bank accounts for a larger percentage of the cross section than in upstream areas. As with the response of the model to channel roughness, a decreasing trend in sensitivity to bank roughness was noted in the upper reaches of the Puyallup River.

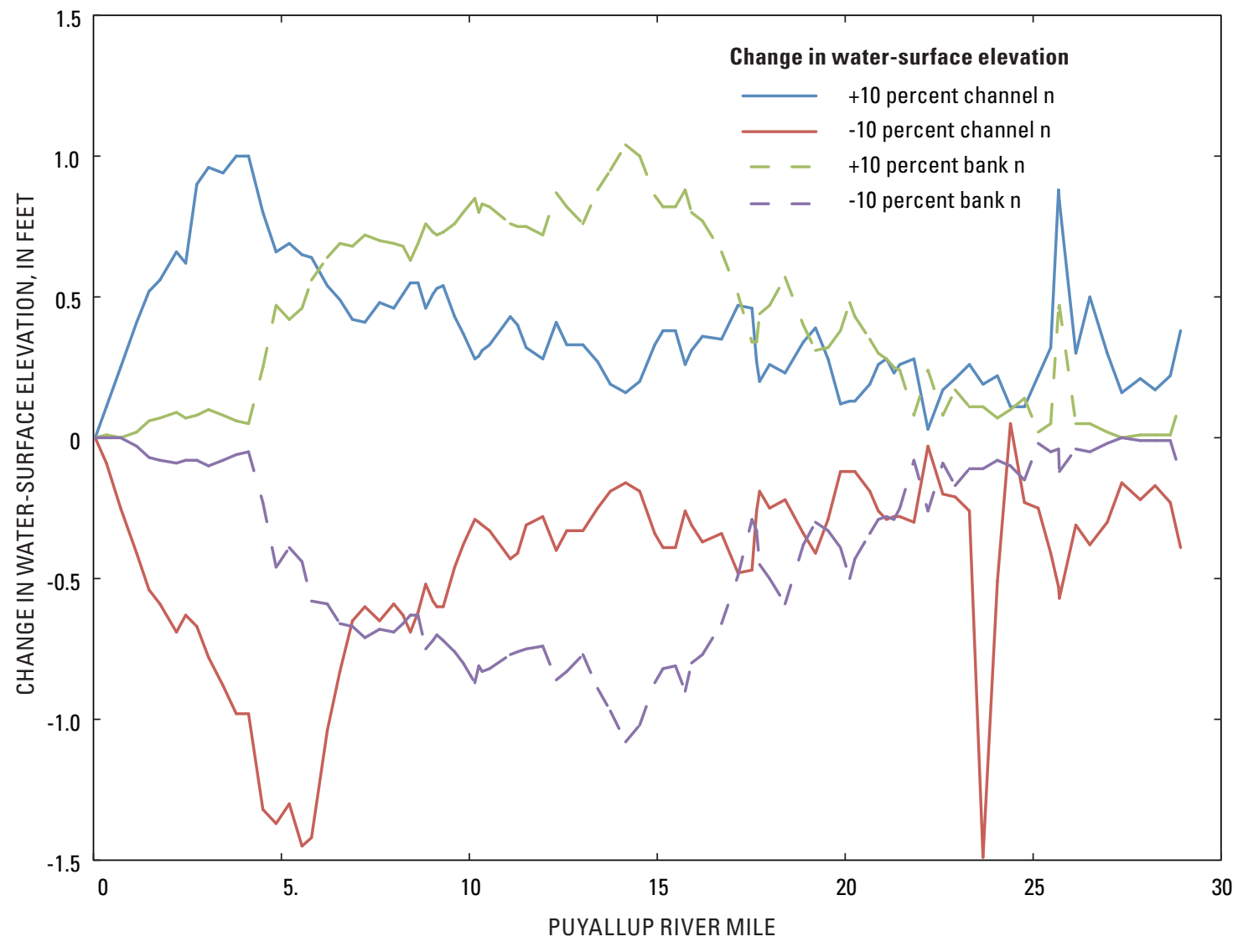

Figure 43. Sensitivity of the 2009 simulated 100 -year recurrence-interval water-surface elevations to simulated changes in roughness for the Puyallup River, western Washington. 
For most of the White River, the water-surface elevation changes by less than $\pm 0.5 \mathrm{ft}$ for change in channel and bank roughness (fig. 44). Downstream of RM 5.5, however, model simulation results show increased sensitivity to bank roughness, probably due to decreasing slope and more overall flow conveyance through the vegetated bank regions. This heightened model sensitivity may support simulations of reductions of channel-conveyance capacity from growth of new vegetation (U.S. Army Corps of Engineers, 2009) for the White River downstream of RM 5.5. In contrast, the model sensitivity seems to indicate that the river is relatively insensitive to changes in roughness along the banks upstream of RM 5.5.
For the Carbon River, the water-surface elevation was relatively insensitive to variations in roughness coefficients of either channel or bank regions because the river has a relatively coarse substrate, steep slope, and small effective bank regions compared to certain reaches of the Puyallup or White Rivers (ig. 45). The overall changes in the water-surface elevation for the sensitivity analysis in the Carbon River were less than $\pm 0.5 \mathrm{ft}$.

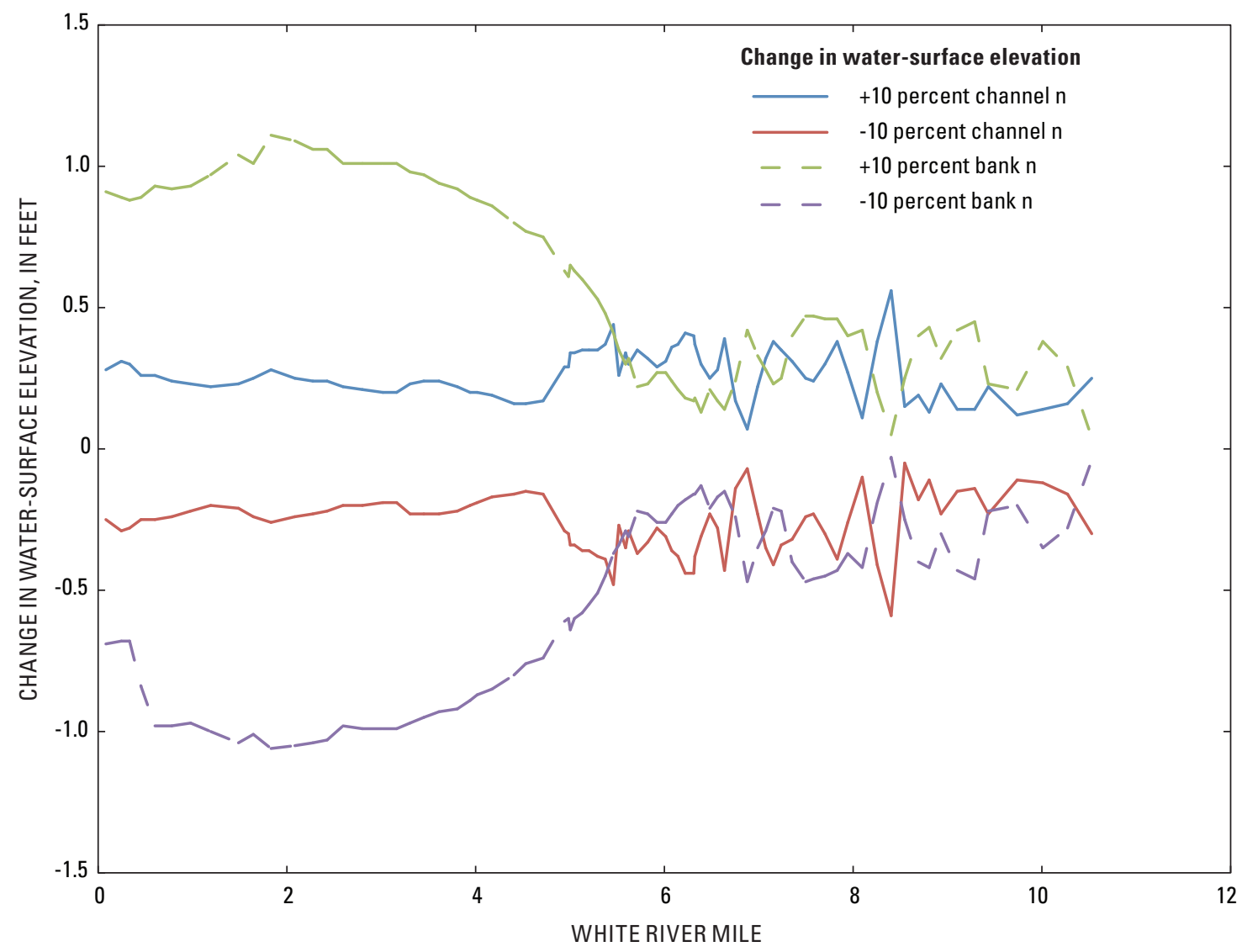

Figure 44. Sensitivity of the 2009 simulated 100 -year recurrence-interval water-surface elevations to changes in roughness for the White River, western Washington. 


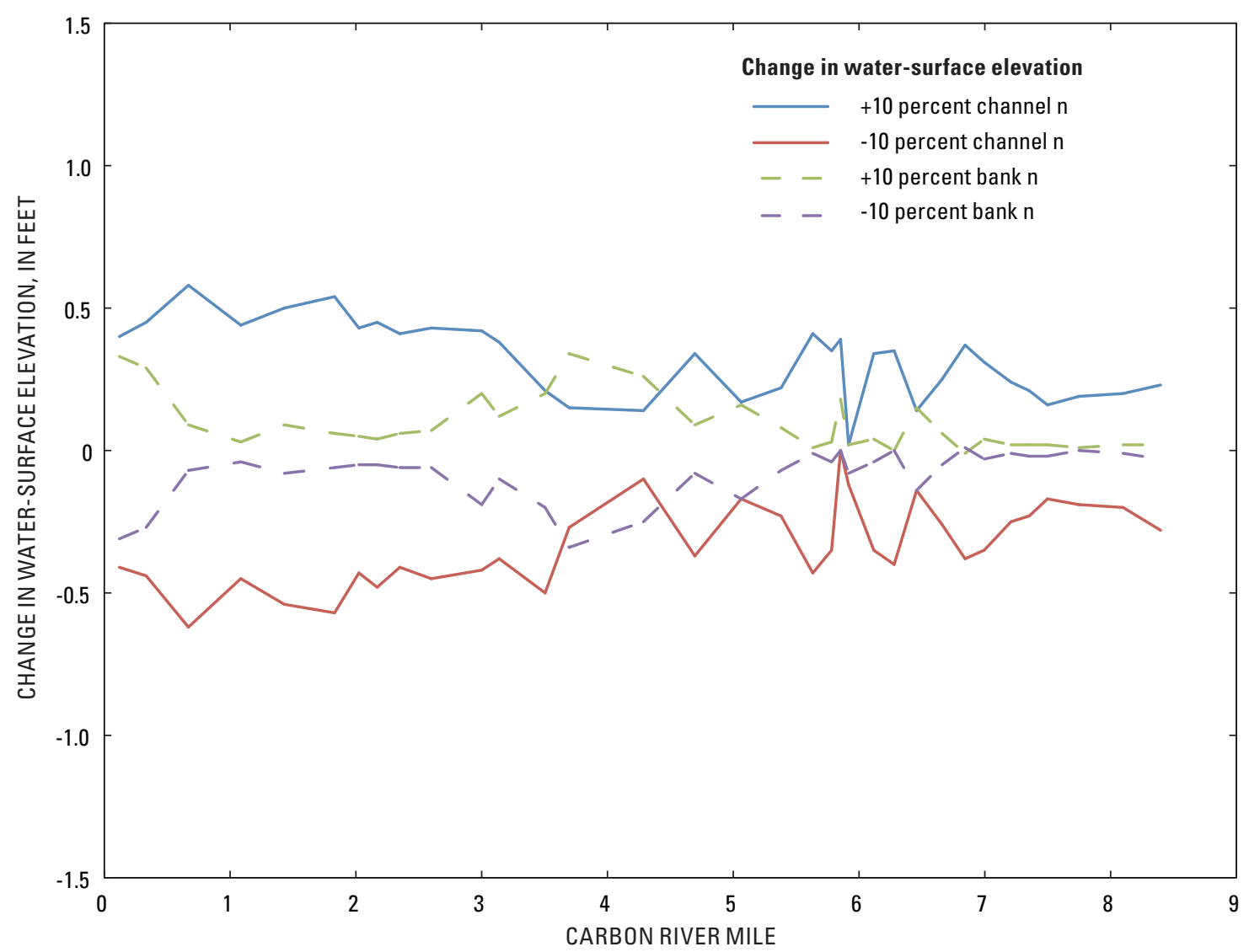

Figure 45. Sensitivity of the 2009 simulated 100-year recurrence-interval water-surface elevations to changes in roughness for the Carbon River, western Washington.

\section{Flow-Conveyance Changes Related to Physical Channel Changes}

Gaging-station data provide information to infer local temporal geomorphic changes in channel elevation and channel-conveyance capacity. Temporal changes in stage (at high, median, and low discharges) (figs. 24-31) and theoretical overtopping discharge (figs. 32-35) indicate that the downstream hydraulic control has changed, which can be attributed to any of the factors affecting flow conveyance including physical bed changes through sediment aggradation or incision, or to changes in channel or bank roughness due to vegetation. Comparing the gaging-station data and changes in the simulated channel-conveyance capacity to physical changes in average-bed elevation determines if changes in bed elevation is the most important factor affecting flow conveyance in the Puyallup, White, and Carbon Rivers.
At gaging station 12101500, Puyallup River at Puyallup, slight aggradation has been measured since the 1980s. The average channel elevation between 1984 and 2009 has increased by approximately $1.1 \mathrm{ft}$ with a similar value of aggradation downstream of the gaging station (fig. 4). Between 1985 and 2009, the stage at high, median, and low discharges showed a slow, steady increase in the lower Puyallup River with an overall aggradation rate of $0.3 \mathrm{in} / \mathrm{yr}$, or $0.6 \mathrm{ft}$ overall (fig. 24; table 7). The theoretical overtopping discharge has decreased by approximately $9,700 \mathrm{ft}^{3} / \mathrm{s}$ (ig. 32) and the channel-conveyance capacity nearest to the gaging station is approximately $40,000 \mathrm{ft}^{3} / \mathrm{s}$, which has decreased by at least approximately 10,000 ft $3 / \mathrm{s}$ since 1984 (fig. 38).

At gaging station 12096500, Puyallup River at Alderton, very slight aggradation has been measured since the 1980s. The average channel elevation between 1984 and 2009 has increased by approximately $0.9 \mathrm{ft}$ with aggradation as large as $2.0 \mathrm{ft}$ just downstream of the gaging station (fig. 4). 
Overall, the average increase in stage at high, median, and low discharges between 1992 and 2008 was approximately $0.1 \mathrm{in} / \mathrm{yr}$, or $0.1 \mathrm{ft}$ overall (ig. B1A; table 7). The theoretical overtopping discharge has decreased by about $8,700 \mathrm{ft}^{3} / \mathrm{s}$ (fig. 33) and the channel-conveyance capacity nearest to the gaging station is approximately $33,000 \mathrm{ft}^{3} / \mathrm{s}$ and has decreased by at least approximately 3,000 ft ${ }^{3} / \mathrm{s}$ since 1984 (fig. 39).

At gaging station 12093500, Puyallup River near Orting, slight incision has been measured since the 1980s. The average channel elevation between 1984 and 2009 has decreased by approximately $0.3 \mathrm{ft}$ (fig. 4). The overall trend in stage at high, median, and low discharges has decreased from 1988 to 2009 by $0.5 \mathrm{in} / \mathrm{yr}$, or $0.9 \mathrm{ft}$ overall (fig. B1B; table 7). The theoretical overtopping discharge has increased by approximately 15,100 ft $3 / \mathrm{s}$ (fig. 34) and the channel-conveyance capacity nearest to the gaging station is greater than $17,000 \mathrm{ft}^{3} / \mathrm{s}$ and has not decreased to less than approximately 17,000 ft $\mathrm{ft}^{3} / \mathrm{s}$ since 1984 (fig. 40).

At gaging station 12100496, White River near Auburn, pronounced aggradation has been measured since the 1980s. The average channel elevation between 1984 and 2009 has increased by approximately $3.5 \mathrm{ft}$ with aggradation as large as $6.5 \mathrm{ft} 0.5 \mathrm{mi}$ downstream (fig. 6). The overall trend in stage at median and high flow generally has increased between 1988 and 2009 by $1.8 \mathrm{in} / \mathrm{yr}$, or $3.2 \mathrm{ft}$ overall, with a significant 2 -ft increase following prolonged peak discharge in 1996 (fig. 26; table 7). The theoretical overtopping discharge decreased by approximately 19,100 ft $3 / \mathrm{s}$ (fig. 35) and the channel-conveyance capacity nearest to the gaging station is approximately $13,000 \mathrm{ft}^{3} / \mathrm{s}$ and has decreased by at least approximately $7,000 \mathrm{ft}^{3} / \mathrm{s}$ since 1984 (fig. 41). Also, the water-surface elevations corresponding to 12,000 and $9,000 \mathrm{ft}^{3} / \mathrm{s}$ have increased by approximately $5.6 \mathrm{ft}$ since 1987 (fig. 36).

At each of the four gaging stations in the study area, an increase in average channel elevation is accompanied by an increase in stage for a given discharge, a decrease in theoretical overtopping discharge, and a decrease in channel-conveyance capacity, which is expected if the flow-conveyance changes were due to channelbed changes. Due to the uncertainties of individual channel- and conveyance-change estimates, no individual estimate definitively proves that channel conveyance has decreased. Together, however, these estimates indicate that flow-conveyance changes have occurred on several reaches of the Puyallup, White, and Carbon Rivers and were mostly due to changes in the channel bed due to aggradation or incision.

\section{Sediment Transport in the Puyallup, White, and Carbon Rivers}

The one-dimensional HEC-RAS hydraulic model was used with additional input data for a sediment-transport analysis. The simulated annual sediment bedload was computed for various hydrologic and sediment-input conditions for the Puyallup, White, and Carbon Rivers.

Sediment entrainment, transport, and deposition in rivers are complex three-dimensional processes, and empirical sediment-transport equations can be imprecise. More importantly, although equations to estimate sediment transport have been available for some time (for example, Einstein, 1950; Lane, 1955; Henderson, 1966), their accuracy when applied to gravel-bedded rivers can vary greatly (Wilcock and others, 2009). In addition to reasonable characterization of the hydraulic conditions in the river of interest, accurate sedimenttransport modeling requires detailed boundary-condition data of sediment input, distribution, and caliber that are sparsely available for the Puyallup River system. All published sediment-transport data sets in the Puyallup River system were used for the analysis in this study (for example, Dunne, 1986; Prych, 1988; Sikonia, 1990), but many key assumptions had to be made to fill data gaps. Considering these limitations, model simulation results from this study of the volume of transported and deposited sediment should be used with caution. Instead, the model simulation results are best interpreted by comparing relative changes between cross sections, time frames, hydrology, or management alterations in specific river reaches.

\section{Methodology of Sediment-Transport Modeling}

The HEC-RAS sediment-transport model (version 4.0) uses a quasi-steady approximation for flow (it approximates a continuous hydrograph with discrete steady-flow profiles) and solves the Exner equation for sediment continuity (a change in channel elevation is related to the difference between the inflowing and outflowing sediment loads) to simulate riverbed change (Brunner, 2008a). Changes to the hydraulic model for the sediment-transport analysis included removing bridge structures and bridge cross sections from the geometry file because unrealistic scour and deposition occurred at these cross sections if bridge geometries were included.

At each simulation time step, HEC-RAS computes the sediment-transport potential (how much material of a particular grain-size class the flow can transport) of each grain-size class (table 5). For this analysis, the Wilcock and Crowe (2003) equation was used to compute the sedimenttransport potential, Report 12 was used as the fall-velocity method, and the Exner 5 algorithm was selected to simulate bed sorting and armoring (Brunner, 2008a). 
The Wilcock and Crowe (2003) equation is a surface-based bedload transport equation developed from flume experiments using sand and gravel mixtures and assumes that transport primarily depends on the sediment-size distribution in direct contact with the flow. This equation includes a hiding function that reduces the transport potential of smaller particles as they become nestled between larger gravel particles and sheltered from the flow; this has the effect of increasing gravel-transport potential as the sand content increases (Wilcock and Crowe, 2003).

Once the transport potential is computed for each grain-size class, the transport capacity for each size class is computed as the transport potential multiplied by the percentage of that size class present in the bed. This algorithm is based on the assumption that the sediment discharge of a size class is proportional to the fractional abundance of that class within the bed (Einstein, 1950). The Exner equation for sediment continuity is applied to each size class separately. The computed transport capacity is compared to the supply of each size class to determine if there is a surplus or deficit. Once this surplus or deficit is determined, a final deposition or erosion volume is computed, which is added or subtracted from the bed morphology of the cross section (Brunner, 2008a). Sediment bedload volumes were converted to mass by assuming a bulk density of sand and gravel of $93 \mathrm{lbs} / \mathrm{ft}^{3}$ (Brunner, 2008a). Simulated changes to the cross-section morphology occur at each wetted cross-section point equally. This modeling assumption does not fully represent the physical processes in fluvial systems, and the two- and threedimensional nature of erosion and deposition in rivers cannot be simulated accurately with HEC-RAS. Sediment attrition, the progressive reduction in size of sediment particles due to collisions, ablation, and weathering as alluvium transports downstream (Benda and Dunne, 1997), was not simulated in the analysis.

\section{Input Data}

Various data inputs are necessary to complete a sedimenttransport analysis. Because the model is hydraulically subcritical, discharge and sediment loads were required at the upstream boundary of the model and water-surface elevation is required at the downstream boundary. Water temperature was defined for the entire model, and bed-material size distributions were defined at every cross section. The 2009 full bed-material size distributions were assigned to the specific cross sections where discharge measurements were made and interpolated for intervening cross sections. At the ends of the model domain, the nearest measured bed-material data were extrapolated to unmeasured cross sections.

Bedload data from Sikonia (1990), measured near the upstream boundaries of the model, were used with the Wilcock and Crowe (2003) equation to compute sediment-transport potential. Sikonia's (1990) bedload measurements included two samples from the Puyallup River (collected at discharges of 2,600 and 4,800 $\mathrm{ft}^{3} / \mathrm{s}$ ), two samples from the Carbon River (collected at discharges of 1,600 and 4,700 $\mathrm{ft}^{3} / \mathrm{s}$ ), and one sample from the White River (collected at a discharge of $11,000 \mathrm{ft}^{3} / \mathrm{s}$ ). The bedload measurements at the smaller flows in the Puyallup and Carbon Rivers were averaged to obtain an estimate for bedload transport in the White River at 2,100 $\mathrm{ft}^{3} / \mathrm{s}$. Each rating curve included a lower bound at $1 \mathrm{ft}^{3} / \mathrm{s}$ assumed to be a load of 0.0011 ton/d. Each rating curve also was extended as much as $20,000 \mathrm{ft}^{3} / \mathrm{s}$ by extrapolation. For the extrapolation to $20,000 \mathrm{ft}^{3} / \mathrm{s}$, the size distribution of the bedload was modified to include cobbles. Rating curves from the nearest measurement location were applied to the upstream boundary conditions. The sediment rating curve of the Carbon River was applied to its two tributaries, South Prairie and Voight Creeks (fig. 2). The White River tributary, Lake Tapps return, was not assigned a sediment rating curve because no bedload was assumed to be in this tributary.

Discharge values for the upstream boundary conditions and tributaries were obtained from gaging stations in the basin. Discharge values reported every 15 minutes were obtained for water years (WY; October 1 of the previous calendar year to September 30) 1999 to 2003 to represent a low-flow period, and for WYs 2005-09 to represent large peak-event years. The upstream boundary conditions where discharge values were specified were the same as those used in the channelconveyance analysis, except at Voight Creek. For Voight Creek, input discharge was assumed to be equal to one-half the discharge from South Prairie Creek. For discharge values less than one-half the mean annual flow, time steps were averaged into 24-hour increments; larger discharge values were averaged into 6-hour increments. These increments enabled longer simulations while maintaining resolution of the actual hydrographs, particularly for larger discharge values when more sediment transport is expected. The downstream boundary condition for all sediment-transport analyses was assumed to be mean sea level (MSL) in Commencement Bay of $4.38 \mathrm{ft}$ (National Oceanic and Atmospheric Administration, 2009). Water-temperature data were obtained from Washington State Department of Ecology water-quality monitoring station 10A050, Puyallup River at Puyallup (which is less than $1 \mathrm{mi}$ downstream of USGS gaging station 12101500), for WYs 2001-2003 (Washington State Department of Ecology, 2010). The temperature data were averaged by month; water temperatures varied from $41^{\circ} \mathrm{F}$ in January to $59^{\circ} \mathrm{F}$ in July. The model uses temperature to determine the fall velocity of sediment particles (Brunner, 2008a). Fall velocity is less sensitive to water temperature for coarse- than for finesediment particles. The sensitivity is particularly low in this study because the fall velocity is high for the coarse-sediment particle sizes simulated in this study (Garcia, 2008). 


\section{Results of Sediment-Transport Simulations}

The HEC-RAS sediment-transport model was run using flows for two 5-year periods (WY 1999 to WY 2003 and WY 2005 to WY 2009). These periods were selected to represent a period of relatively low flow (WYs 1999-2003) and a period containing high peak-discharge events (WYs 2005-2009) within a continuous 5-year period.

The sediment-transport analysis for this study considered only sediment transported as bedload and not total sediment load, which also includes suspended load. The simulated bedload transported to the mouth of the Puyallup River, therefore, is only a small fraction of the total sediment load delivered to Puget Sound by the Puyallup River system. Based on the sediment-load measurements in the White River, for example, Nelson (1979) calculated the total bedload as 4 percent of the total suspended load. The bedload transported in various reaches is influenced by the size of material transported into the reach and the size of material that exists on the bed within the reach. Differences in bedload transport within a reach can cause the channel bed to aggrade or incise.

Where the bedload increases in the downstream direction, sediment was generally entrained from the bed, and where bedload decreases in the downstream direction, sediment was generally deposited on the bed. Near the upstream end of the model and at major tributaries (mainly South Prairie Creek on the Carbon River), the bedload increases in the downstream direction for a few miles. The model adjusts the bedload downstream of boundary inputs by entraining sediment from the bed. This was mostly due to the uncertainty in the sediment inputs, as few data were used to develop the input sediment-rating curves, and bedload data for high flows were extrapolated from data measured during lower flows.

At the beginning of every sediment-transport simulation, initial sediment entrainment, transport, and deposition were simulated during the model start-up that resulted from the model adjusting its initial conditions (for instance, slope and bed-material size distributions) to values more numerically stable. This tended to slightly increase sediment transport, compared to expected amounts, during the first year of a model simulation.

\section{Simulated Annual Bedload Sediment Transport}

Bedload is the volume or mass of sediment transported along the bed by rolling, sliding, or saltating (hopping). The annual bedload was computed for every year for the Puyallup, White, and Carbon Rivers based on the bedload-transport capacity calculated by the HEC-RAS sediment-transport model.
The simulated annual bedload through the Puyallup River was largest near RM 25, ranging from about 20,000 to $50,000 \mathrm{yd}^{3} / \mathrm{yr}$, and generally decreased downstream (ig. 46). At RM 10.3 and RM 17.5, the annual bedload abruptly increased because of water and sediment inputs from the White and Carbon Rivers, respectively. Downstream of RM 4, the annual volume of bedload increases, because the bed of the river in this reach is dominated by sand which is transported more readily than the mixed sand, gravel, and cobble bed upstream. Away from boundary effects, the bedload decreased most abruptly between RM 20 and 25 indicating sediment deposition in this reach. This reach includes the Ford and Soldiers' Home setback-levee reaches, extends just downstream of the Calistoga Bridge, and corresponds to a region where the bed elevation has increased from 1984 to 2009. A large decrease in bedload for WYs 2007 and 2009 was measured just downstream of the confluence with the White River indicating sediment deposition in this region for these years, and corresponds to an increase in bed elevation between 1984 and 2009 (fig. 4).

The simulated annual bedload through the White River was largest near RM 9, ranging from about 5,000 to $70,000 \mathrm{yd}^{3} / \mathrm{yr}$, and generally decreased downstream (fig. 47). The largest simulated bedload was for WYs 2007 (which includes the peak-of-record flood in November 2006) and 2009. The lowest simulated bedload was for WY 2001. Downstream of RM 3, the annual volume of bedload increased, which is similar to the lower $4 \mathrm{mi}$ of the Puyallup River, and where the bed of the White River for the lower $3 \mathrm{mi}$ is dominated by sand that is transported more readily than the mixed sand, gravel, and cobbles. The largest decrease in bedload downstream, indicating sediment deposition, was between RMs 4 and 8, which corresponds to the large increase in channel elevation between 1984 and 2009 (fig. 6).

The simulated annual bedload through the Carbon River was largest near RM 4, ranging from about 5,000 to 25,000 $\mathrm{yd}^{3} / \mathrm{yr}$ (fig. 48). The bedload in the Carbon River generally did not decrease downstream, as in the Puyallup and White Rivers, because Voight Creek and South Prairie Creek provided additional water and sediment to the Carbon River at RM 4 and RM 5.7, respectively. The largest decrease in bedload downstream was near RM 3, which corresponds with Voight Creek. The constant bedload in the Carbon River downstream of Voight Creek indicates the river is capable of transporting most sediment through this reach without aggrading or incising the river channel. 


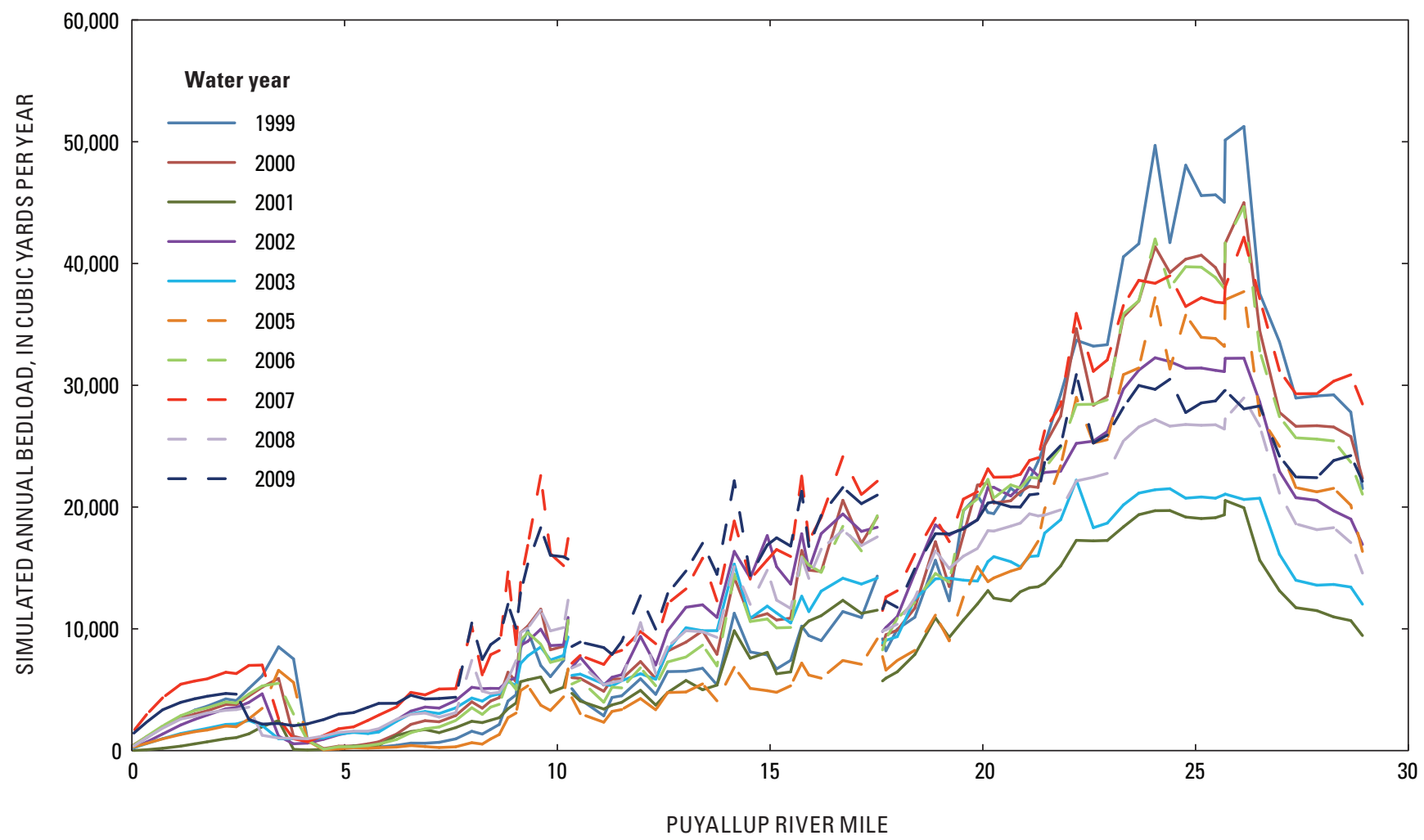

Figure 46. Simulated annual bedload as a function of river location for the Puyallup River, western Washington, water years 1999-2003 and 2005-09.

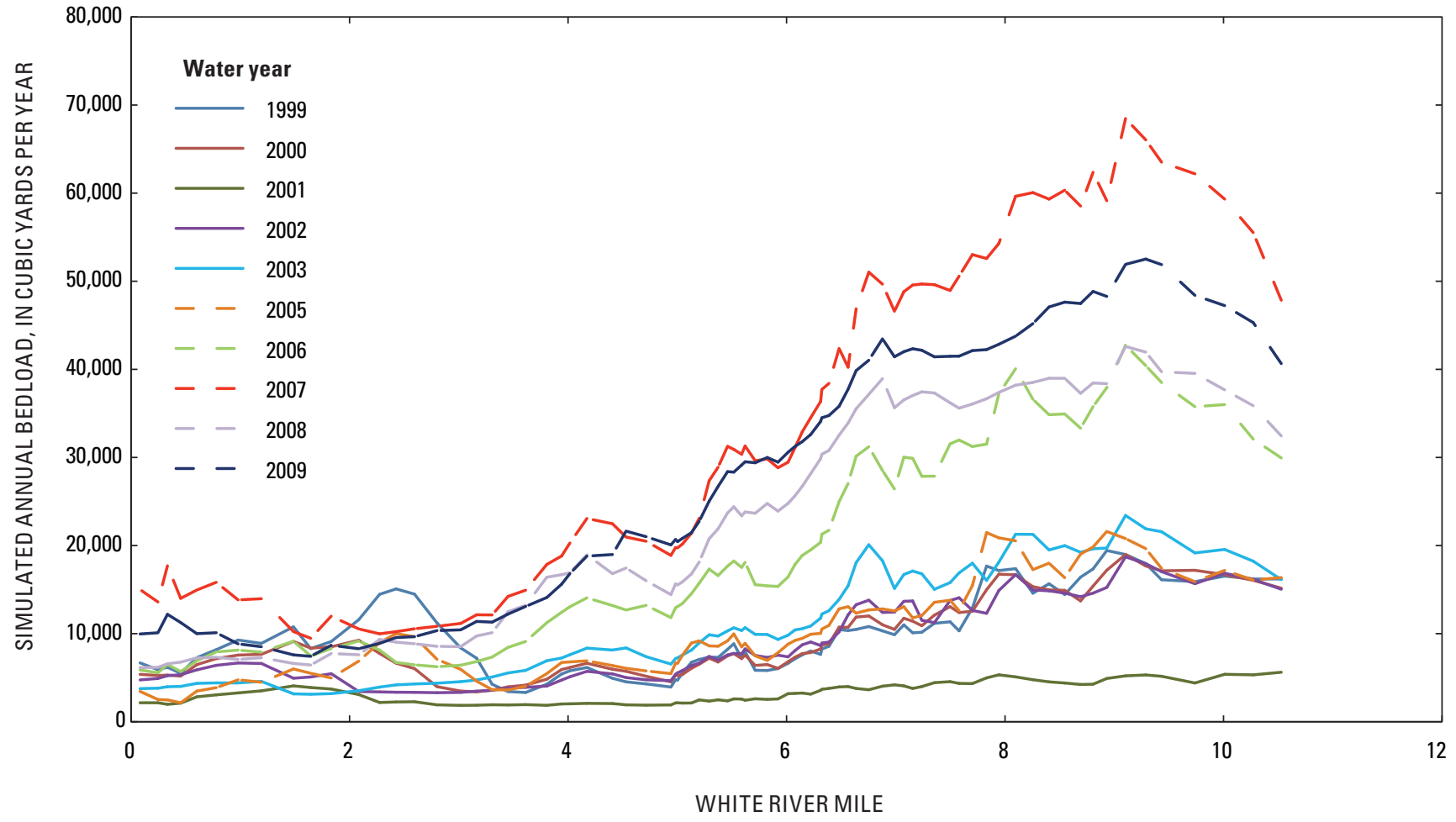

Figure 47. Simulated annual bedload as a function of river location for the White River, western Washington, water years 1999-2004 and 2005-09. 


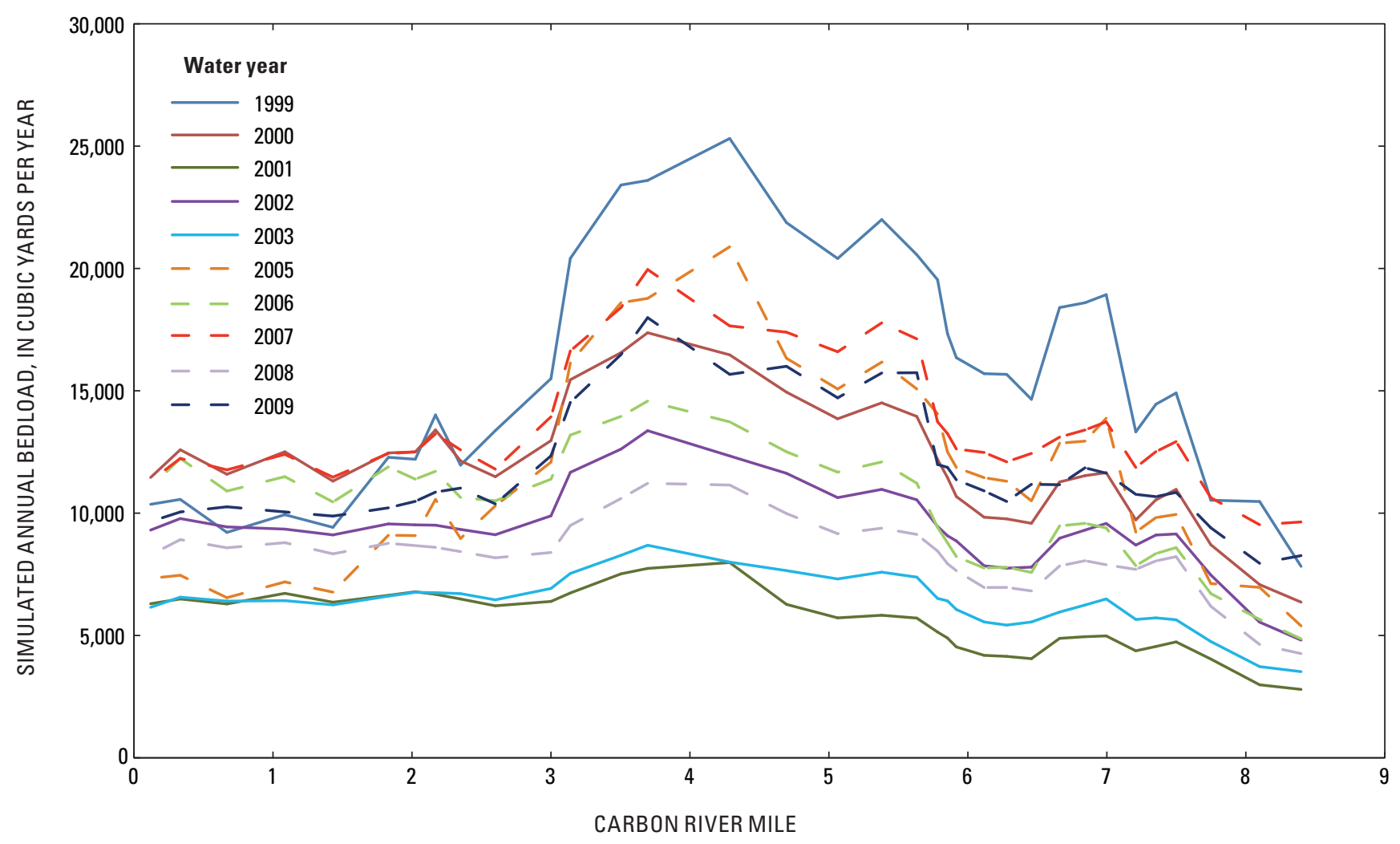

Figure 48. Simulated annual bedload as a function of river location for the Carbon River, western Washington, water years 1999-2003 and 2005-09.

\section{Simulated Average Annual Bedload Sediment Transport by Grain-Size Group for 5-Year Periods}

The simulated 5-year average bedloads were segregated by grain size into three groups (table 5 ): sand and finer (referred to as sand), gravel, and cobbles and larger (referred to as cobbles) for the Puyallup, White, and Carbon Rivers, respectively.

Similar to the simulated annual bedload, the simulated 5-year average annual bedload through the Puyallup River was largest near RM 25, ranging from 30,000 to 35,000 $\mathrm{yd}^{3} / \mathrm{yr}$, and generally decreased downstream (fig. 49). Sand bedload represented at least half of the total bedload through the Puyallup River in the upper Puyallup River and increased downstream. Gravel bedload was largest upstream of RM 21 and cobble bedload was largest upstream of RM 23.

Similar to the simulated annual bedload, the simulated 5-year average annual bedload through the White River was largest near RM 9, ranging from 15,000 to 45,000 $\mathrm{yd}^{3} / \mathrm{yr}$, and generally decreased downstream (fig. 50). Sand bedload represented at least half of the total bedload through the White River and increased downstream, similar to the Puyallup River. Gravel and cobble bedload was largest near RM 9 and decreased downstream. Fine-grained sediment transport was always larger than coarse-grained sediment transport because more energy (higher flow) is required to transport coarser sediment.
The simulated annual bedload in the White River for WY 1999-2009 (except 2004) (5,000-60,000 $\mathrm{yd}^{3} / \mathrm{yr}$ ) and the simulated 5-year average annual bedload in the White River for WYs 1999-2003 and WYs 2005-09 (15,000 to $45,000 \mathrm{yd}^{3} / \mathrm{yr}$ ) are consistent with the ranges determined by previous studies. Estimated bedload in the White River above MMD was 16,000 yd from June 1974 to June 1975 and 40,000 $\mathrm{yd}^{3}$ between June 1975 and June 1976 (Nelson, 1979). Dunne (1986) used Nelson's (1979) data and computed the 10-year (1966-76) average annual bedload of about $16,000 \mathrm{yd}^{3}$ with annual totals ranging from 5,000 to $45,000 \mathrm{yd}^{3}$ in the White River above MMD. Herrera Environmental Consultants (2010) estimated the annual bedload yield of the White River as 55,000-110,000 $\mathrm{yd}^{3} / \mathrm{yr}$ using a temperate-basin sediment model.

Similar to the simulated annual bedload, the simulated 5-year average annual bedload through the Carbon River was largest near RM 4, ranging from 14,000 to $16,000 \mathrm{yd}^{3} / \mathrm{yr}$ (fig. 51). Sand transported as bedload through the Carbon River remained relatively constant at about half of the total bedload transported. Gravel bedload was greater than cobble bedload and both were significant contributors to the total bedload through the Carbon River. 


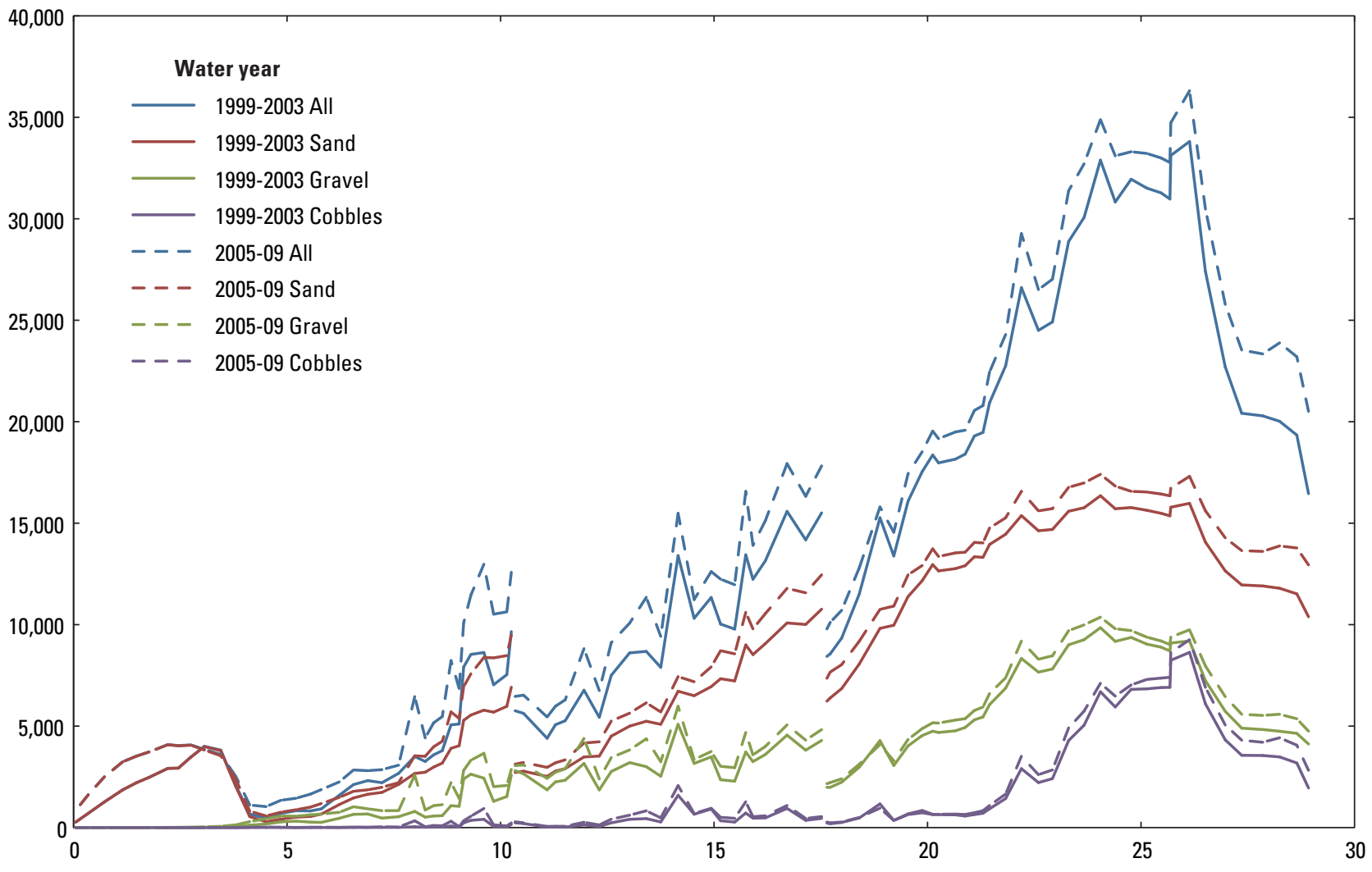

PUYALLUP RIVER MILE

Figure 49. Simulated annual bedload by grain size for each simulation period for the Puyallup River, western Washington, water years 1999-2003 and 2005-09.

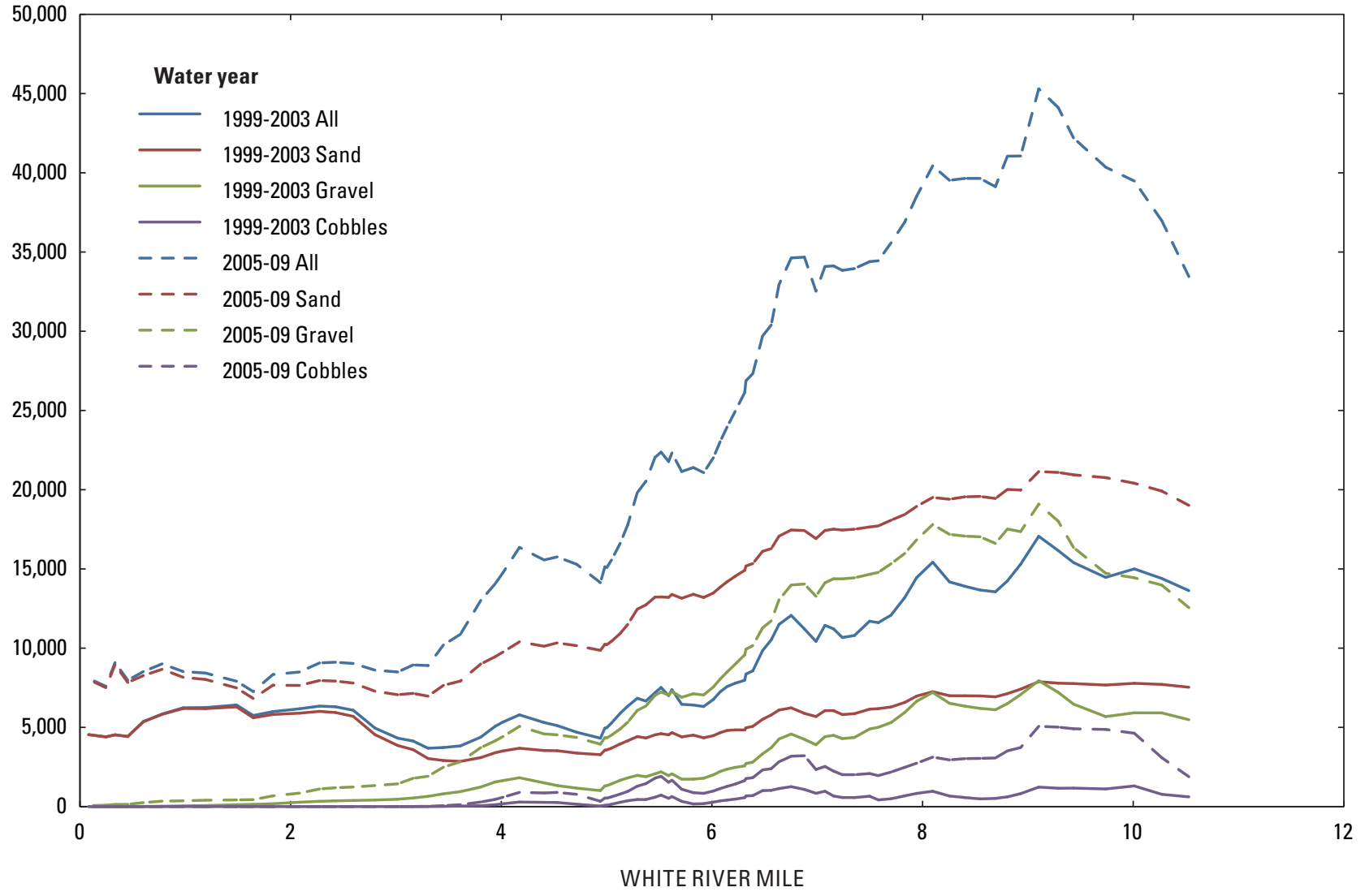

Figure 50. Simulated annual bedload by grain size for each simulation period for the White River, western Washington, water years 1999-2003 and 2005-09. 


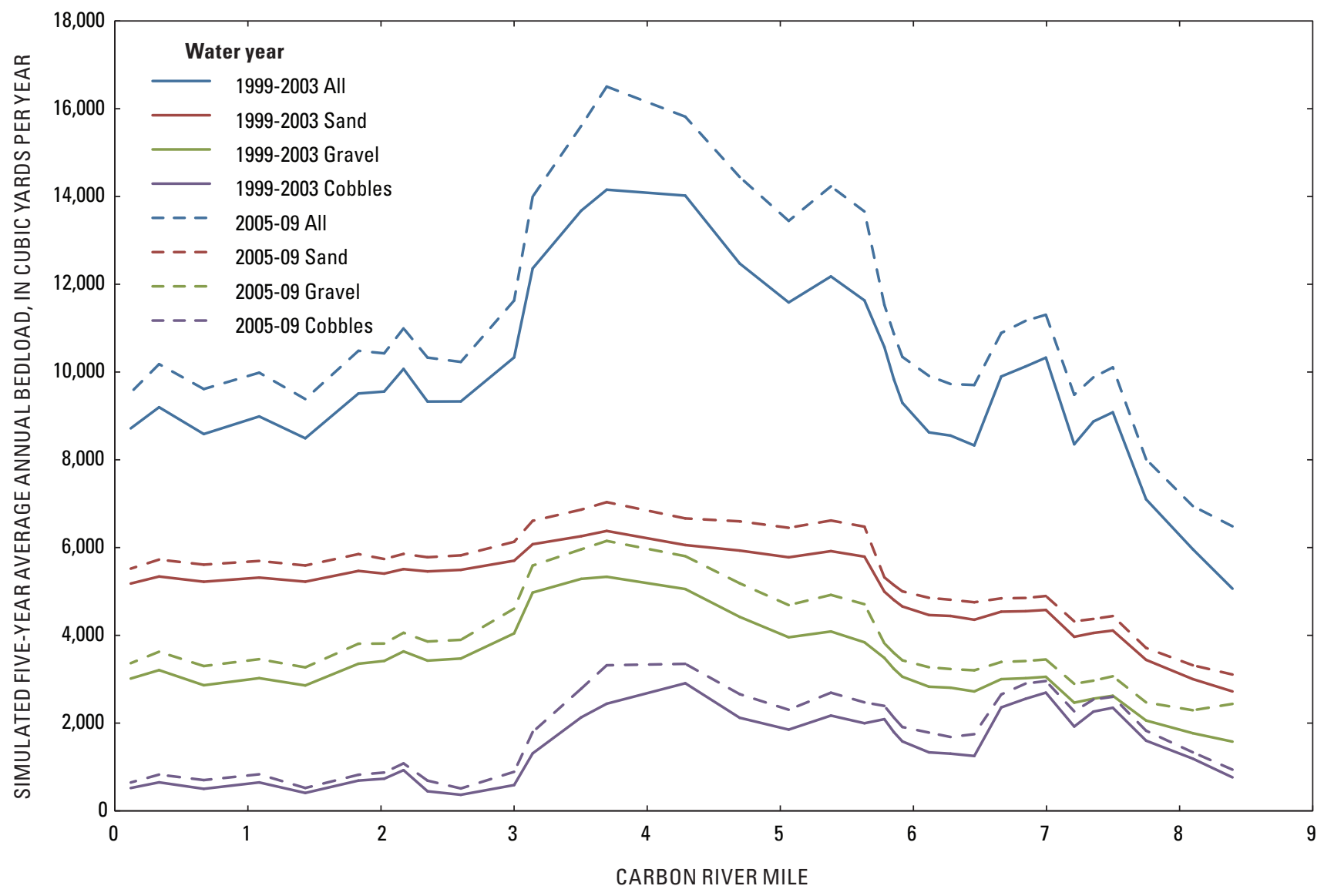

Figure 51. Simulated annual bedload by grain size for each simulation period for the Carbon River, western Washington, water years 1999-2003 and 2005-09.

\section{Analysis of River-Management Options River-Management Options}

The HEC-RAS sediment-transport model was used to investigate how different river-management options would affect channel conveyance and sediment transport throughout the river network. The model was modified to simulate three river-management options: gravel-bar scalping, setback levees, and a combination of both. These management options were investigated at three river-management sites identified by Pierce County: Puyallup River near Orting, White River near the Pierce-King County line, and Puyallup River near Sumner. Each river-management option was compared to the baseline condition with no geometric modifications. Considering the limitations of the sediment-transport model as described in that section of this report, simulation results from this study of the volume of transported and deposited sediment and the timing of the transport processes should be used with caution. Instead, the modeling results are best interpreted by qualitatively comparing relative changes between different river-management options.
The gravel-bar scalping option was simulated by modifying cross-section geometry within the management reach. The cross-section elevation representing the gravel bars was modified to simulate excavation starting at a point near the summer low-flow and extending upward toward the bank at a 2 percent slope, consistent with current permitting requirements and the Washington Administrative Code (WAC 220-110-140 (7)) (Randy Brake, Pierce County, written commun., 2009). If a side channel was in the original cross section, the slope of the simulated excavated area of the cross section was graded downward at a 2 percent slope to the side channel. If significant vegetation was on a gravel bar where the gravel was to be removed, the roughness of the vegetated section of the cross section was adjusted to the previously calibrated value of the nearby unvegetated sections.

The volume of sediment removed from the gravel-bar scalping option was computed using the average end-area volume computation method (Breed, 1916): the cross-sectional area removed by gravel-bar scalping from adjacent cross 
sections was averaged and then multiplied by the distance between the cross sections to compute a volume of sediment removed between cross sections. The volume of sediment removed from the reach by the gravel-bar scalping option was then computed by summing the volumes of sediment removed between cross sections within the reach.

The setback-levee option was simulated by first extending cross sections to the location of the proposed setback levee. The setback levee was then built into the model as an elevated ground point in the cross-section geometry. The elevations of the setback levees were assumed to be either the same height as the confining high point on the opposite bank or the height above the surrounding floodplain to contain large discharges. Existing levees on the same bank as the new setback levee were removed from the model. The roughness of the extended floodplain was assigned a value consistent with the roughness of vegetated banks of the baseline condition.

The third river-management option combined gravel-bar scalping with setback levees. Geometry files from the gravel-bar scalping and the setback-levee options were merged to investigate the combined effect of both options on flow conveyance and sediment transport.

\section{Methodology of River-Management-Option Simulations}

The river-management sites identified by Pierce County were selected because they are reaches with large sediment deposits, with reduced channel-conveyance capacity, are located where modifications are feasible, and where modifications would not adversely affect critical fish habitat. The first simulated river-management site was a reach of the Puyallup River near Orting, referred to as the Calistoga reach due to its location downstream of the Calistoga Road Bridge. The next simulated river-management site was a reach of the White River near the Pierce-King County line, referred to as the Countyline reach. This reach includes most of the river distance between the 8th Street and A Street Bridges. The final simulated river-management site was a reach of the Puyallup River just upstream of its confluence with the White River near Sumner. This reach is referred to as the Sumner reach.

After constructing a river-management option, the HEC-RAS model was run with an instantaneous peak event with a recurrence interval of approximately 100 years to evaluate the initial response of the water-surface elevation and channel conveyance to the modified geometry. The water-surface elevations for the baseline condition were subtracted from water-surface elevations simulated for each river-management option to show the initial river response immediately after the management modification.
To overcome the initial sediment entrainment, transport, and deposition simulated during model start-up as the model adjusts its initial conditions (for instance, slope and bed-material size distributions) to more numerically stable values, a constant high flow was simulated for each river-management site for 90 flow-days. The 90 flow-days simulation does not imply the simulated change will occur within this period. Instead, the flow and timescale were selected to qualitatively assess the relative differences between river-management options after considerable geomorphic work has occurred on the channel without regard to the actual timescale involved. The cumulative bed-volume change after 90 days at a constant high flow was computed to show the spatial distribution of sediment deposition and erosion within and near the modified reach. The cumulative bed-volume change at each cross section represents a volume of sediment deposited halfway between the upstream and downstream cross sections. The cumulative bed-volume change was summed over the reach after 15-day increments during the 90-day simulation for each reach to show the progression of sediment accumulation within the reach over time for each river-management option. The water-surface elevation change between the baseline condition and modified geometry after 90 days were compared to show the change in water-surface elevation due to sediment deposition within and near each modified reach.

The flow regimes from two 5-year periods (WYs 1999-2003 and 2005-09) were simulated to determine the effects of the management options on sediment transport. These periods were selected to represent a period of relatively low flow (WY 1999-2003) and a period containing high peakdischarge events (WY 2005-09). The bed-volume change in each modified reach was summed after each year to estimate the cumulative change in sediment volume in the reach for various flow conditions.

\section{River-Management Options for the Puyallup River in the Calistoga Reach}

The Calistoga reach referred to in this analysis is from RM 20.7-21.5, within which a proposed modification of the right levee would move the levee away from the river by about $400 \mathrm{ft}$ (fig. 52). The cross sections modified in the Calistoga reach were P122, P123, P124, P125, and P126. Gravel-bar scalping was simulated as occurring in the same cross sections as the setback levee. The modified channel geometry used for the gravel-bar scalping option simulated the removal of approximately 52,200 $\mathrm{yd}^{3}$ of sediment. 


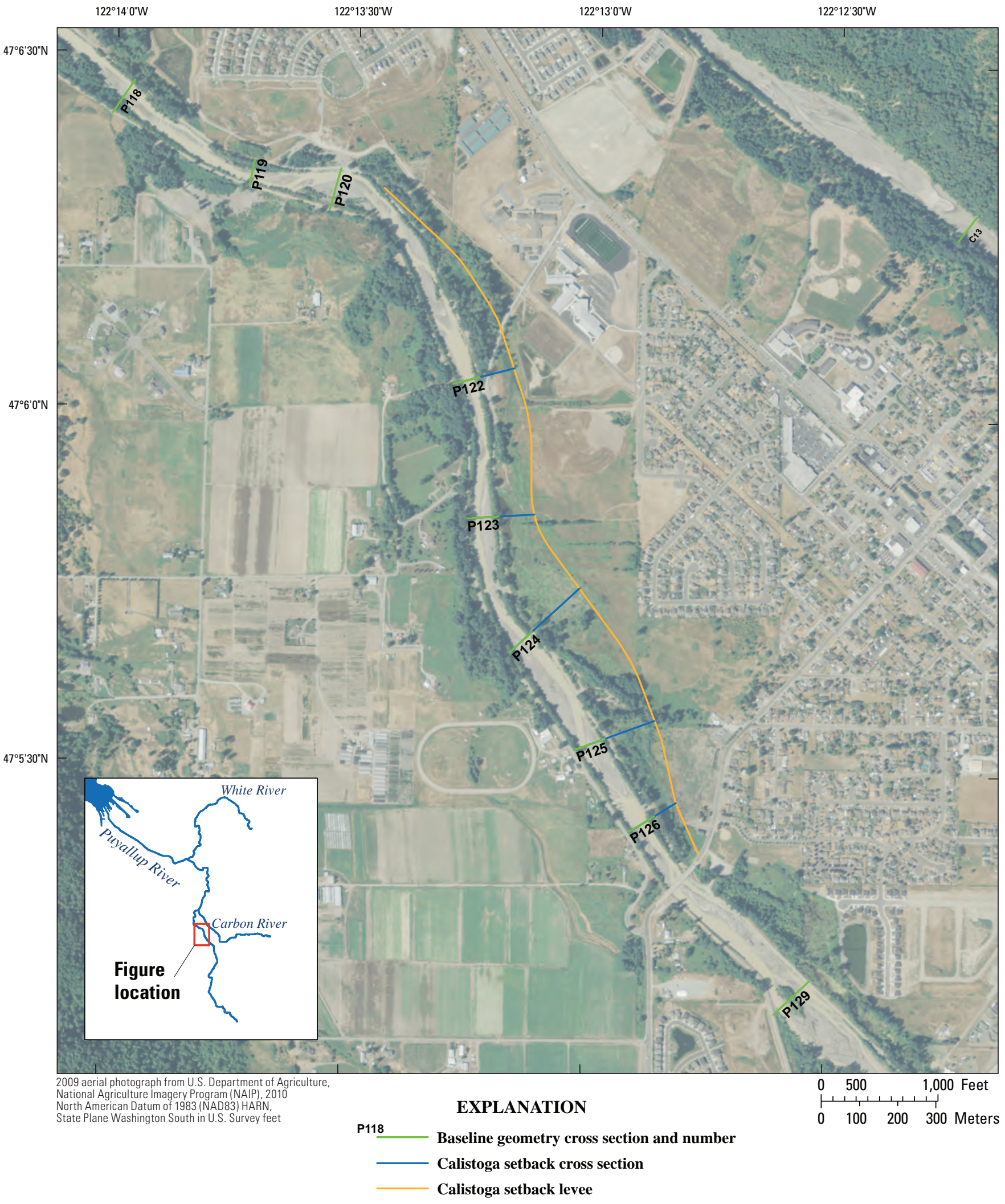

Figure 52. Calistoga reach river-management site along the Puyallup River, western Washington. 
With the modified channel geometry, the water-surface elevation in and upstream of the Calistoga reach would decrease using all management options compared to the baseline condition (fig. 53). The results of the combined gravel-bar scalping and setback-levee options were not appreciably different from the setback-levee option alone; therefore, the combined results were omitted from this analysis. The initial maximum drop in water-surface elevation at a discharge of $18,000 \mathrm{ft}^{3} / \mathrm{s}$ would be $0.8 \mathrm{ft}$ at RM $21.1 \mathrm{for}$ the gravel-bar scalping option and $3.2 \mathrm{ft}$ at RM 21.3 for the setback-levee option. Gravel-bar scalping would increase the channel cross-sectional area through physical removal of gravel, which would increase the channel capacity. The increased channel capacity would reduce the initial water-surface elevation compared to the baseline condition. Setback levees would allow the river to spread out over its floodplain at high flows and would increase the channel cross-sectional area by incorporating a large storage area, increased channel capacity, and reduced initial water-surface elevation compared to the baseline condition.
Most rivers, including those analyzed here, have subcritical flow, a flow regime under which the water-surface elevation upstream is controlled by water-surface elevations downstream. Therefore, a decreased water-surface elevation downstream would lower the water-surface elevations upstream as far as the influence of the hydraulic control. Upstream of the Calistoga reach, at RM 21.8, the water-surface elevation would be lowered by about $0.1 \mathrm{ft}$ with the gravel-bar scalping option and $1.1 \mathrm{ft}$ with the setbacklevee option, compared to the baseline condition. The initial maximum decrease in the water-surface elevation for the setback-levee option would be at the upstream end of the Calistoga reach because downstream geometry changes would continue to lower the upstream water-surface elevations within the management reach. The maximum upstream extent of the lowered water surface would extend about $0.75 \mathrm{mi}$ upstream of the geometric modifications in the Calistoga reach.

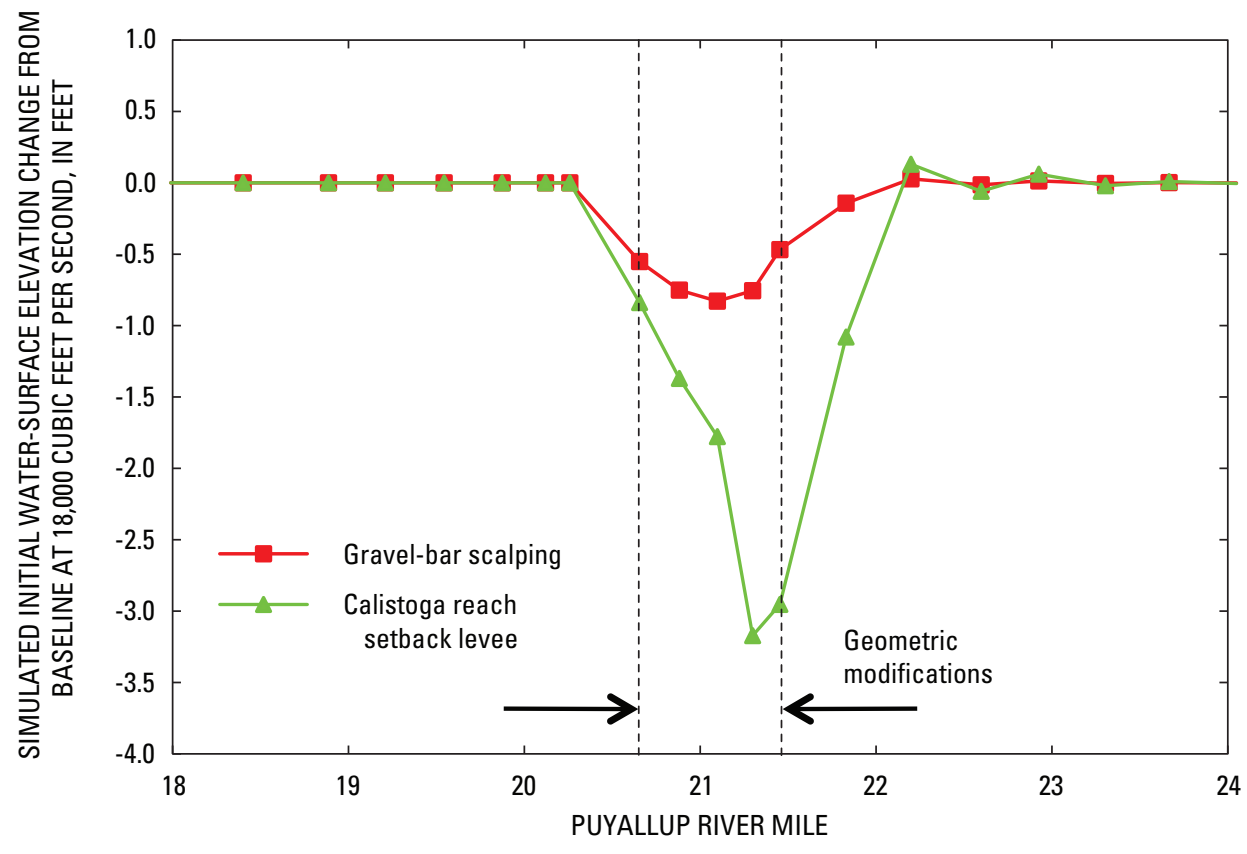

Figure 53. Simulated initial change in water-surface elevation at a discharge of 18,000 cubic feet per second from management modification relative to the baseline condition for the Calistoga reach along the Puyallup River, western Washington. Model simulation results are best interpreted by qualitatively comparing relative changes between different river-management options. 
The cumulative bed-volume change after 90 days of constant high flow $\left(18,000 \mathrm{ft}^{3} / \mathrm{s}\right)$ simulated in the Calistoga reach would show sediment deposition within and near the reach (fig. 54). Sediment deposition with the gravel-bar scalping option would have a spatial distribution similar to and would be slightly higher than the baseline condition within the Calistoga reach, with a maximum deposition in the Calistoga reach of about 20,000 $\mathrm{yd}^{3}$ at $\mathrm{RM} 20.9$. Sediment deposition for the gravel-bar scalping option would be slightly less than the baseline condition just upstream and downstream of the Calistoga reach. Compared to the baseline condition, in the gravel-bar scalping option slightly more sediment would deposit upon entering the reach as the excavated gravel from scalped bars is replaced with deposited sediment. Less sediment would be transported downstream of the reach because more sediment deposits within the reach. Sediment deposition for the setback-levee option would be much greater than the baseline condition and gravel-bar scalping option within the Calistoga reach, with a maximum deposition in the Calistoga reach of about 50,000 $\mathrm{yd}^{3}$ at RM 21.1. Compared to the baseline condition, for the setback-levee option more sediment would deposit upon entering the reach due to decreased sediment-transport capacity as the flow spreads out over the floodplain. Upstream of the Calistoga reach, however, sediment deposition for the setback-levee option would be much less than the baseline condition and gravel-bar scalping option, approximately 25,000 $\mathrm{yd}^{3}$ for the setback-levee option compared to approximately 95,000 $\mathrm{yd}^{3}$ for the gravel-bar scalping option and the baseline condition at RM 21.9. The lower water-surface elevation in the Calistoga reach would lower water-surface elevations, increase flow velocities, and increase sediment-transport capacity upstream of the reach, which would result in decreased sediment deposition upstream of the reach.

Summing the bed-volume change over the Calistoga reach after 15 day increments at $18,000 \mathrm{ft}^{3} / \mathrm{s}$ would result in a constant rate of sediment accumulation over time (ig. 55). The setback-levee option would accumulate the most sediment compared to the gravel-bar scalping option and the baseline condition, approximately 125,000 $\mathrm{yd}^{3}$ after 90 days. The gravel-bar scalping option would accumulate slightly more sediment than the baseline condition in the Calistoga reach, approximately 65,000 $\mathrm{yd}^{3}$ and 55,000 $\mathrm{yd}^{3}$ after 90 days, respectively.

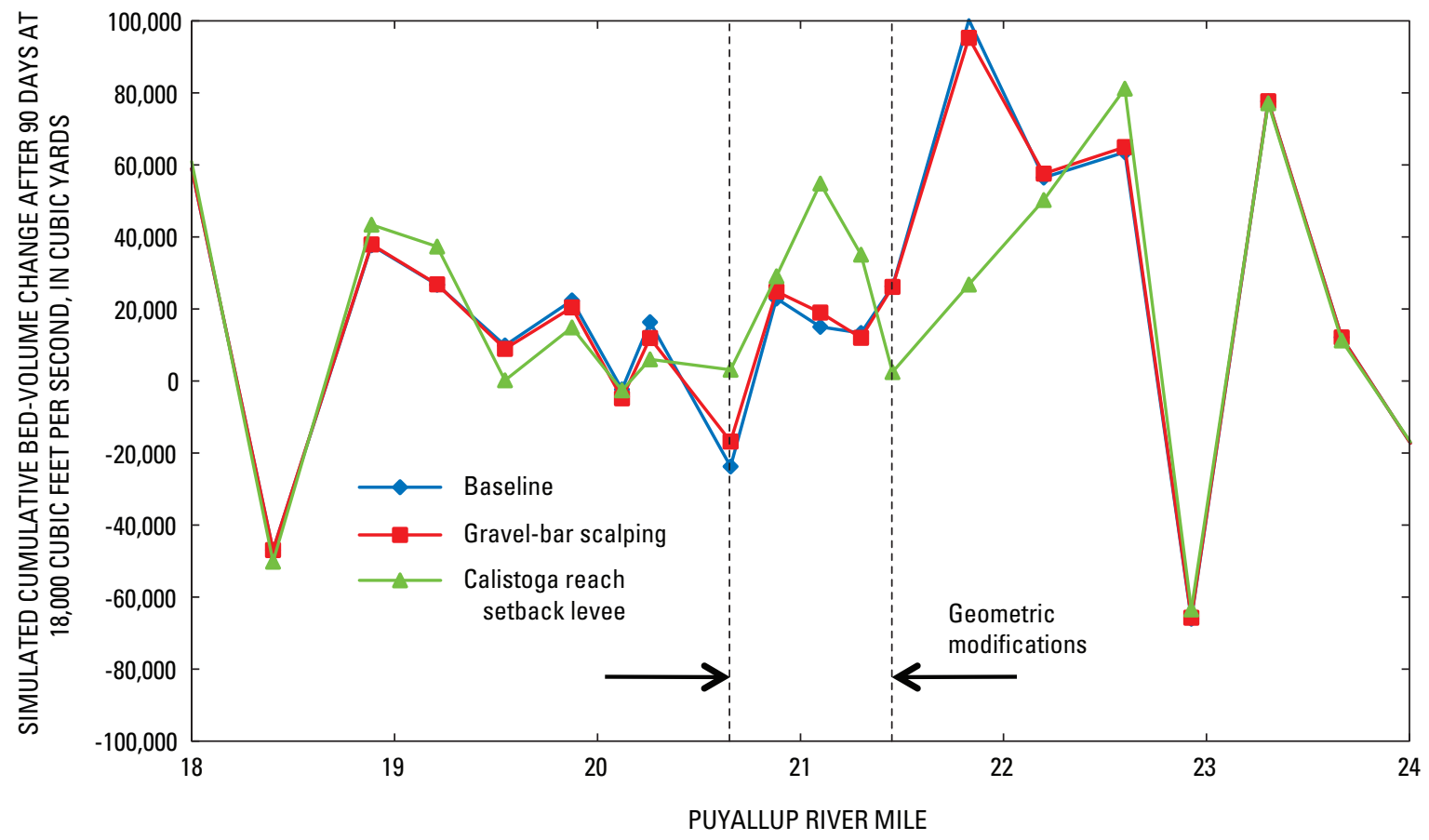

Figure 54. Simulated cumulative bed-volume change after 90 days at a discharge of 18,000 cubic feet per second in the Calistoga reach along the Puyallup River, western Washington. Model simulation results are best interpreted by qualitatively comparing relative changes between different river-management options. 


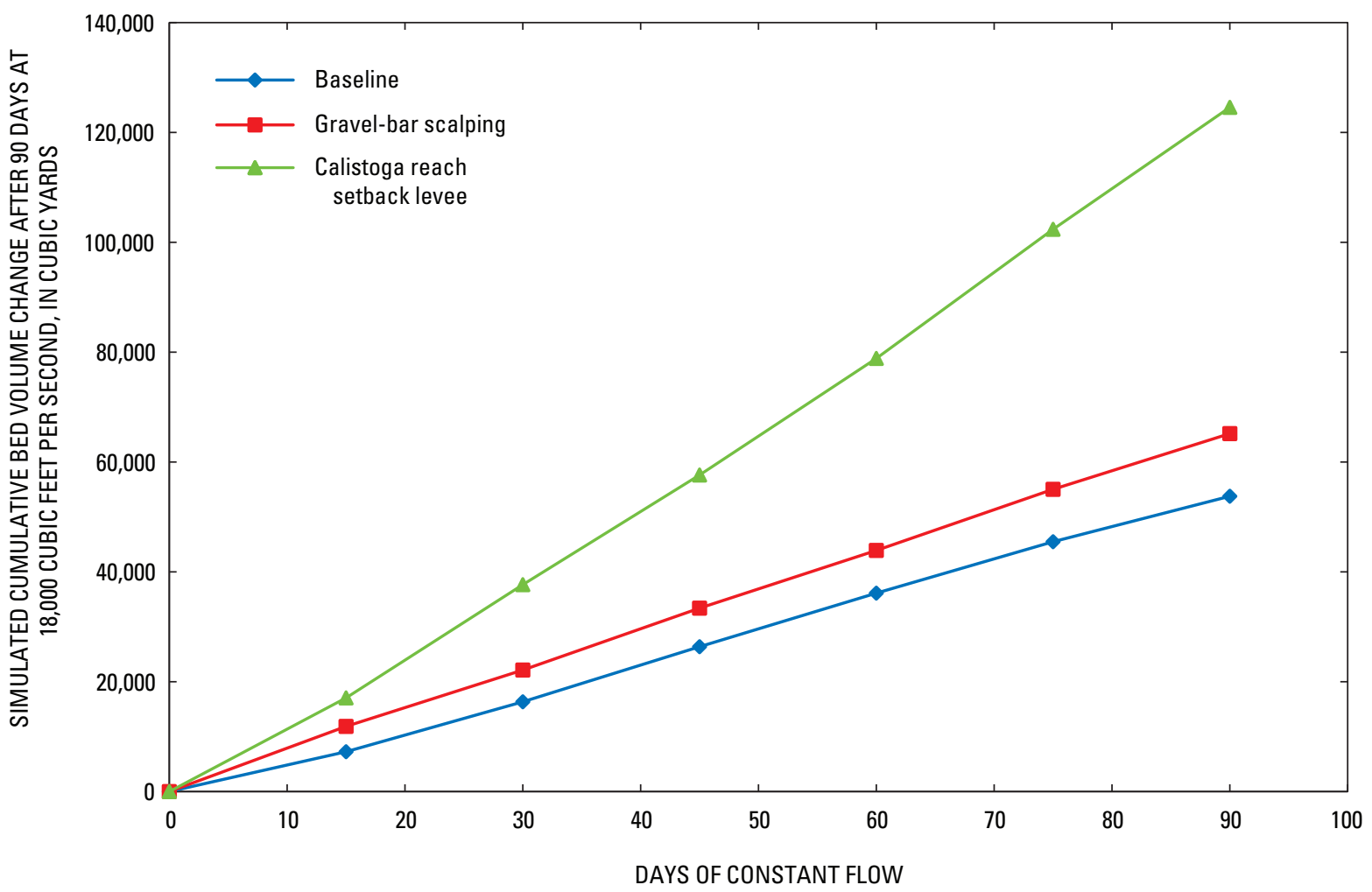

Figure 55. Simulated cumulative bed-volume change at a discharge of 18,000 cubic feet per second for sediment management options in the Calistoga reach along the Puyallup River, western Washington. Model simulation results are best interpreted by qualitatively comparing relative changes between different river-management options.

At a discharge of $18,000 \mathrm{ft}^{3} / \mathrm{s}$, the change from the initial water-surface elevation to the water-surface elevation after 90 days of constant flow would show the effect of sediment deposition in and near the reach on water-surface elevation for different river-management options at high flows (fig. 56). In the Calistoga reach, the change in water-surface elevation for the gravel-bar scalping option would be distributed similarly to and slightly higher than the baseline condition, with a maximum increase in water-surface elevation of $2.1 \mathrm{ft}$ and $1.8 \mathrm{ft}$ at RM 21.1 for the gravel-bar scalping and baseline condition, respectively. Just upstream and downstream of the reach, the change in water-surface elevation for the gravelbar scalping option would be slightly less than the baseline condition. The change in water-surface elevation for the gravel-bar scalping option directly corresponds to sediment deposition in and near the reach. The water-surface elevation change for the setback-levee option would be slightly less than or similar to the baseline condition and the gravel-bar scalping option within the river-management reach, with a maximum increase in water-surface elevation of $1.6 \mathrm{ft}$ at RM 21.3. Even though the setback-levee option would show a greater volume of sediment deposition in the reach, the setback-levee option would still show a similar or lower change in high-flow water-surface elevation than the gravelbar scalping option or baseline condition. The water-surface elevation for the setback-levee option would be less sensitive to sediment deposition than the gravel-bar scalping option because the additional floodplain capacity of the setback levee would allow water to spread out and would provide a larger area for sediment deposition. Upstream of the Calistoga reach, the change in water-surface elevation for the setback-levee option would be much less than the water-surface elevation change for the baseline condition and the gravel-bar scalping option, with an increase of $0.3 \mathrm{ft}$ for the setback-levee option compared to an increase of approximately $2.9 \mathrm{ft}$ for the gravel-bar scalping and baseline condition at RM 21.9. This change in water-surface elevation upstream of the Calistoga reach would be much less than the change resulting from the gravel-bar scalping option and the baseline condition because the model simulates that less sediment is deposited upstream of the reach. 


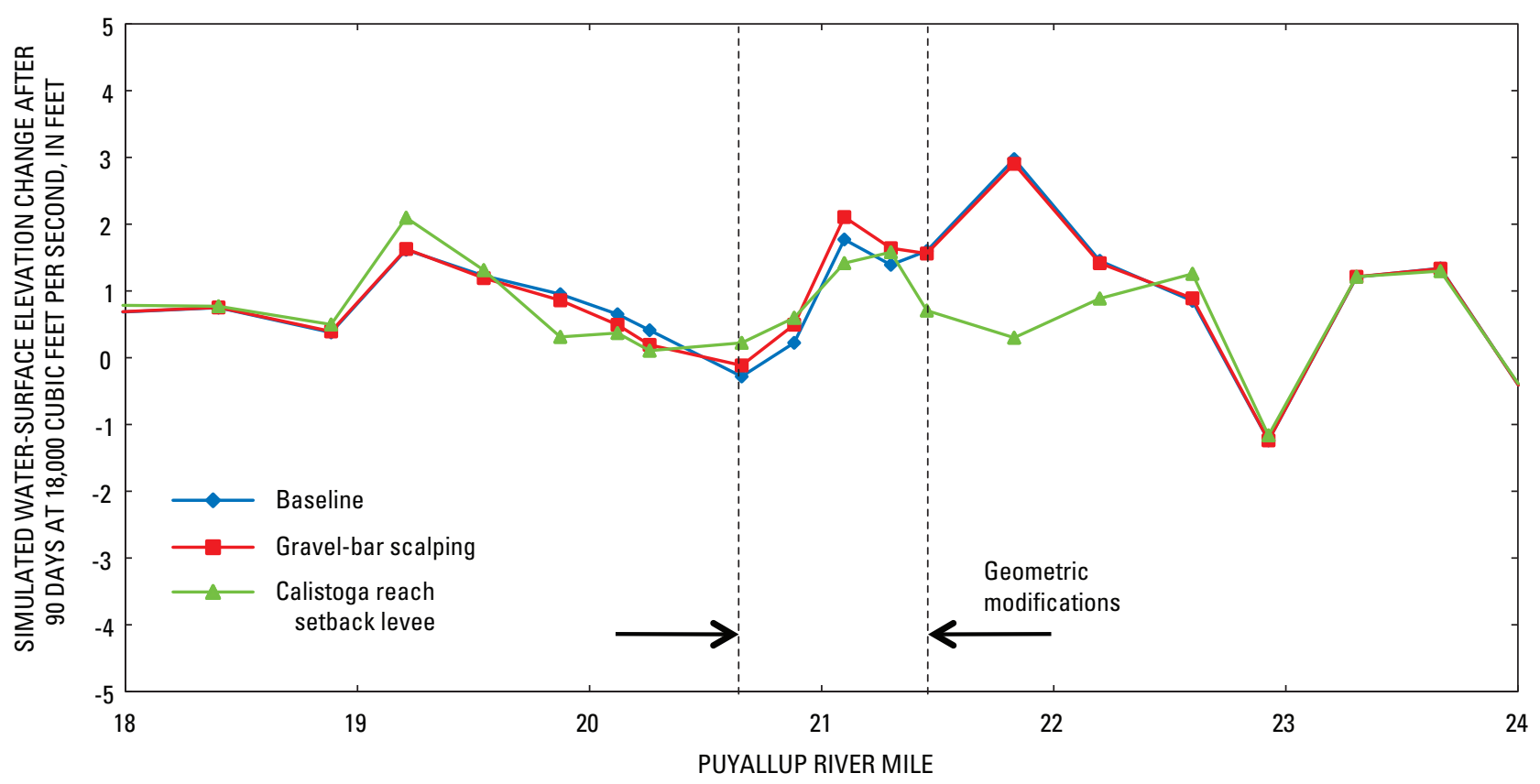

Figure 56. Simulated water-surface elevation change after 90 days at a discharge of 18,000 cubic feet per second for the Calistoga reach along the Puyallup River, western Washington. Model simulation results are best interpreted by qualitatively comparing relative changes between different river-management options.

The annual bed-volume change in the Calistoga reach for different river-management options was computed for the simulation periods WYs 1999-2003 and WYs 2005-09. The annual bed-volume change varied from about 500 to $1,500 \mathrm{yd}^{3}$ but did not vary as expected for various flow conditions. These results were not consistent with the continuous flow results because most of the sediment entrainment, transport, and deposition simulated for these 5-year periods were driven by the model adjusting its local channel slopes upon start-up. The results for annual bed-volume changes in the Calistoga reach for different river-management options for simulation periods WYs 1999-2003 and WYs 2005-2009 were not included because they were unreliable.

\section{River-Management Options for the White River near the Pierce-King County Line}

The Countyline reach referred to in this analysis is from RM 5.2 to 6.0 for a setback levee and from RM 5.1-6.4 for gravel-bar scalping. Modified channel geometry for the Countyline reach was provided by King County for simulation of gravel-bar scalping or a setback levee, with the latter geometry based on preliminary design information for possible future setback-levee projects in this reach (Terry Butler, King County, written commun., 2010) (fig. 57). For this analysis, levee removal was simulated along the left bank between RMs 5.3 and 6.0 for 10 cross sections from King
Co. RM 5.292 to King Co. RM 6.013, and along the right bank between RMs 5.6 and 5.8 for four cross sections from King Co. RM 5.589 to King Co. RM 5.822. A setback levee was simulated along the left bank between RMs 5.2 and 5.6 including seven cross sections from King Co. RM 5.197 to King Co. RM 5.621. Because of the extent of the left bank levee removal, however, four additional cross sections from King Co. RM 5.712 to King Co. RM 6.013 were extended to a terrace that would function as a setback levee between RM 5.7 and RM 6.0. Along the right bank, a setback levee was simulated between RM 5.5 to RM 6.0 including seven cross sections from King Co. RM 5.517 to King Co. RM 6.013. Simulation of gravel-bar scalping occurred between RM 5.1 to RM 6.4 and included 17 cross sections from King Co. RM 5.123 to King Co. RM 6.390, except for cross section King Co. RM 5.517 at RM 5.5 because a low top-of-bar elevation was in this section and the mid-channel bar probably could not be scalped (Terry Butler, King County, written commun., 2010). The modified channel geometry used for the gravel-bar scalping option simulated the removal of approximately 50,200 $\mathrm{yd}^{3}$ of sediment.

Similar to the results for the Calistoga reach, all management options in the Countyline reach would reduce the initial water-surface elevation compared to the baseline condition (fig. 58). The results of the combined gravel-bar scalping and setback-levee options would not be appreciably different from the setback-levee option alone; therefore, the combined results were omitted from this analysis. 
$122^{\circ} 15^{\prime} 0^{\prime \prime} \mathrm{W}$

$122^{\circ} 14^{\prime} 30 " \mathrm{~W}$

$122^{\circ} 14^{\prime} 0^{\prime \prime} \mathrm{W}$

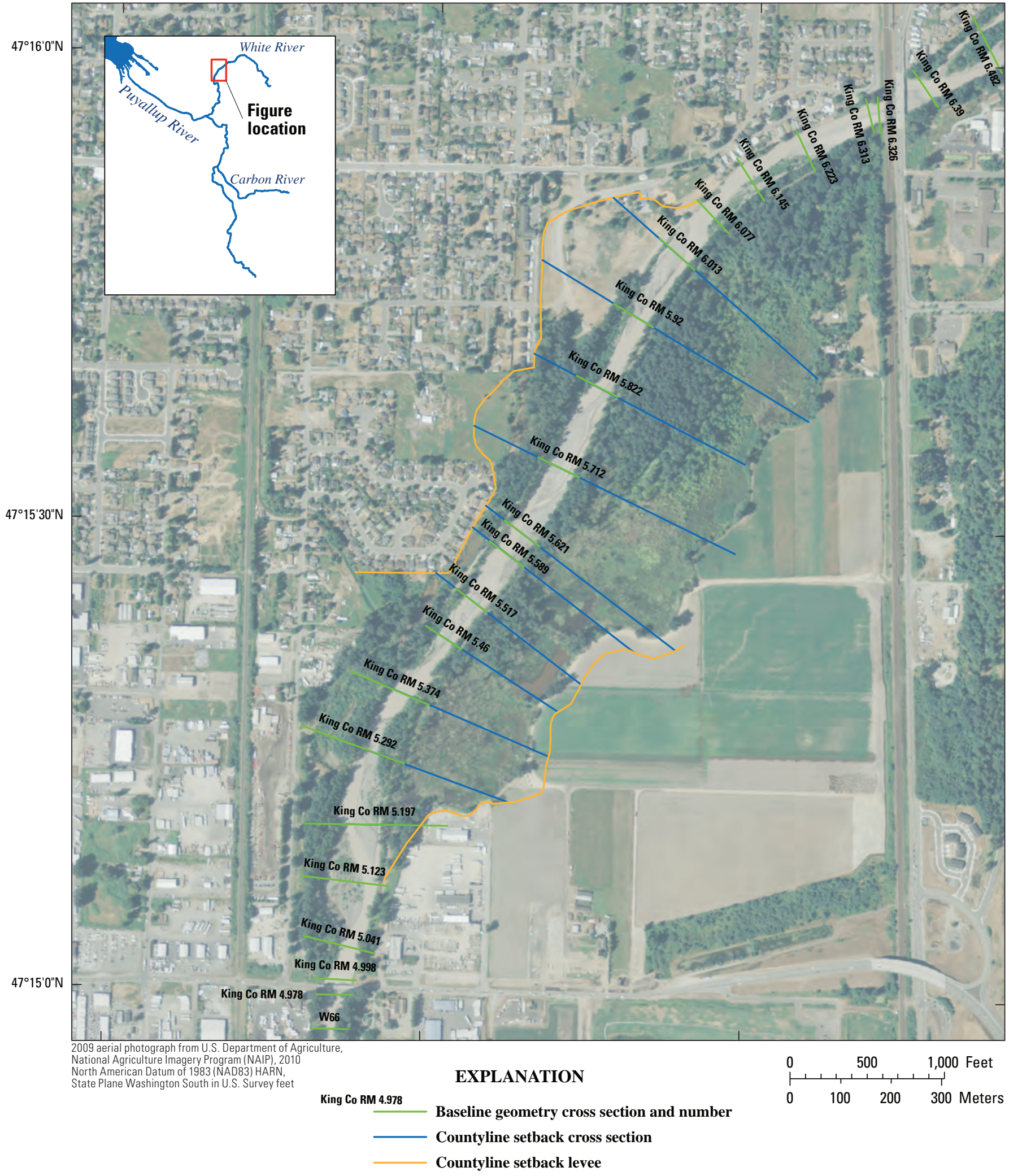

Figure 57. Countyline reach river-management site along the White River, western Washington. 


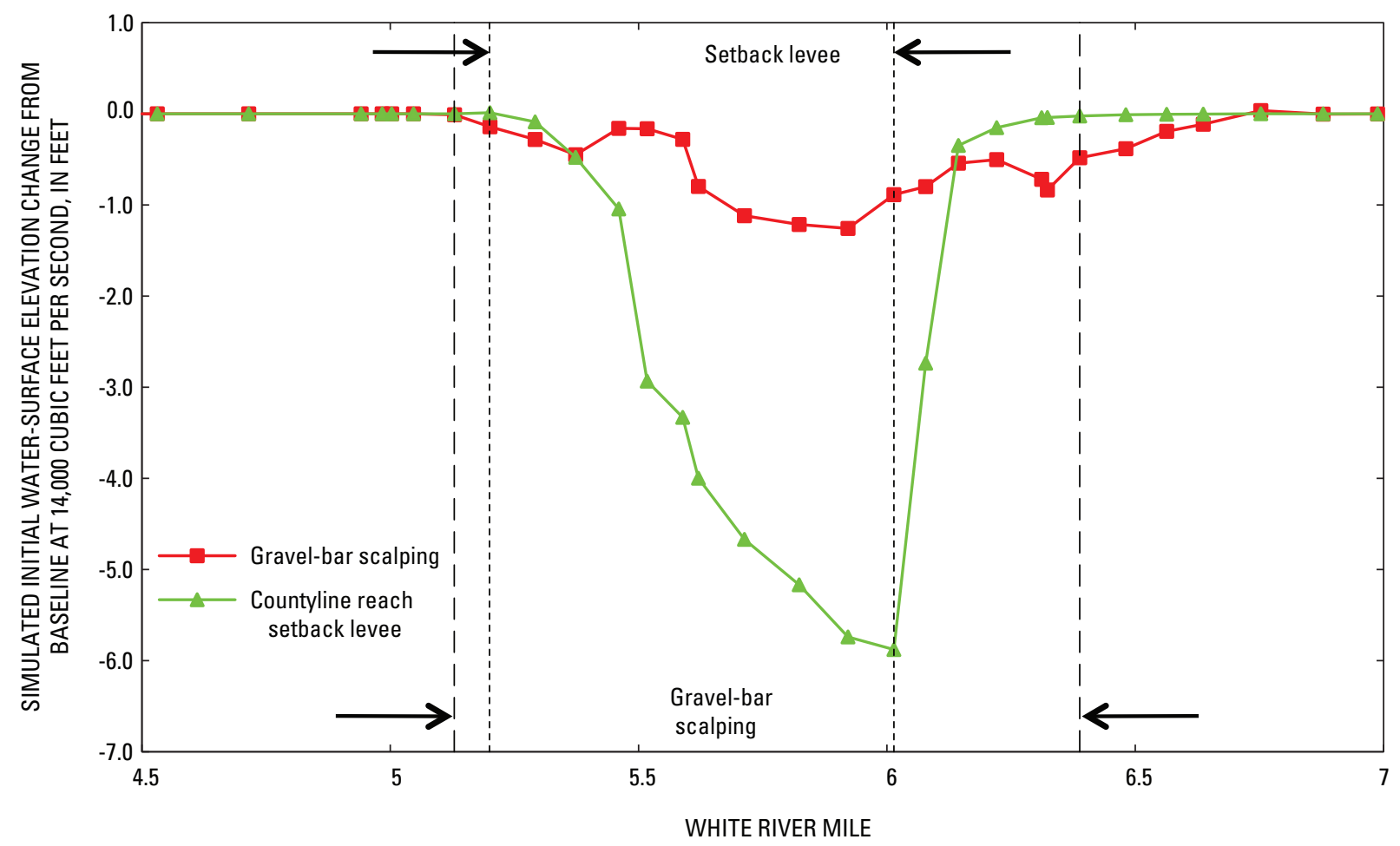

Figure 58. Simulated initial change in the water-surface elevation at a discharge of 14,000 cubic feet per second from management modification relative to the baseline condition for the Countyline reach along the White River, western Washington. Model simulation results are best interpreted by qualitatively comparing relative changes between different river-management options.

The undulation in the initial water-surface elevation for the gravel-bar scalping option compared to the baseline condition near RM 5.4 was because no gravel was removed from the river at cross section King Co. RM 5.517. The initial maximum drop in water-surface elevation at a discharge of $14,000 \mathrm{ft}^{3} / \mathrm{s}$ would be $1.3 \mathrm{ft}$ at RM 5.9 for the gravel-bar scalping option and $6 \mathrm{ft}$ at RM 6 for the setback-levee option. As shown for the Calistoga reach, increased channel capacity for the gravel-bar scalping and setback-levee options would reduce the initial water-surface elevation compared to the baseline condition. The water-surface elevations upstream of the Countyline reach would be lowered for all options due to the change in hydraulic control in the modified reach. The maximum upstream extent of the lowered water-surface elevation would propagate approximately 0.4 mi upstream of the respective geometric modifications.

The cumulative bed-volume change after 90 days at a constant high flow $\left(14,000 \mathrm{ft}^{3} / \mathrm{s}\right)$ simulated in the Countyline reach would show the spatial distribution of sediment deposition and erosion within and near the reach (fig. 59). Sediment deposition for the gravel-bar scalping option would be distributed similarly to the baseline condition downstream of RM 5.5; however, the non-uniform scalping of the gravel bars (more in some cross sections and less in others) in the Countyline reach would obscure general trends compared to the baseline condition. The maximum difference in the bed-volume change between the gravel-bar scalping option and the baseline condition was at RM 5.8, where approximately 12,000 $\mathrm{yd}^{3}$ of sediment would be deposited for the gravel-bar scalping option and approximately 8,000 $\mathrm{yd}^{3}$ of sediment would be eroded from the cross section for the baseline condition. Sediment deposition for the setbacklevee option at the upstream end of the setback-levee section of the Countyline reach would be much greater than the baseline condition and gravel-bar scalping option. Sediment deposition would be approximately $25,000 \mathrm{yd}^{3}$ for the setback-levee option compared to approximately 7,000 $\mathrm{yd}^{3}$ for the gravel-bar scalping option and 3,000 $\mathrm{yd}^{3}$ for the baseline condition at RM 6. Just as simulated in the Calistoga reach for the setback-levee option, more sediment would deposit upon entering the reach compared to the baseline condition. This would be due to decreased sediment-transport capacity as the flow spreads out over the floodplain. Upstream of the Countyline reach, sediment deposition for the setback-levee option would be much less than the baseline condition and gravel-bar scalping option, where approximately $17,000 \mathrm{yd}^{3}$ of sediment would be eroded from RM 6.1 for the setback-levee option compared to deposition of approximately 5,000 $\mathrm{yd}^{3}$ 


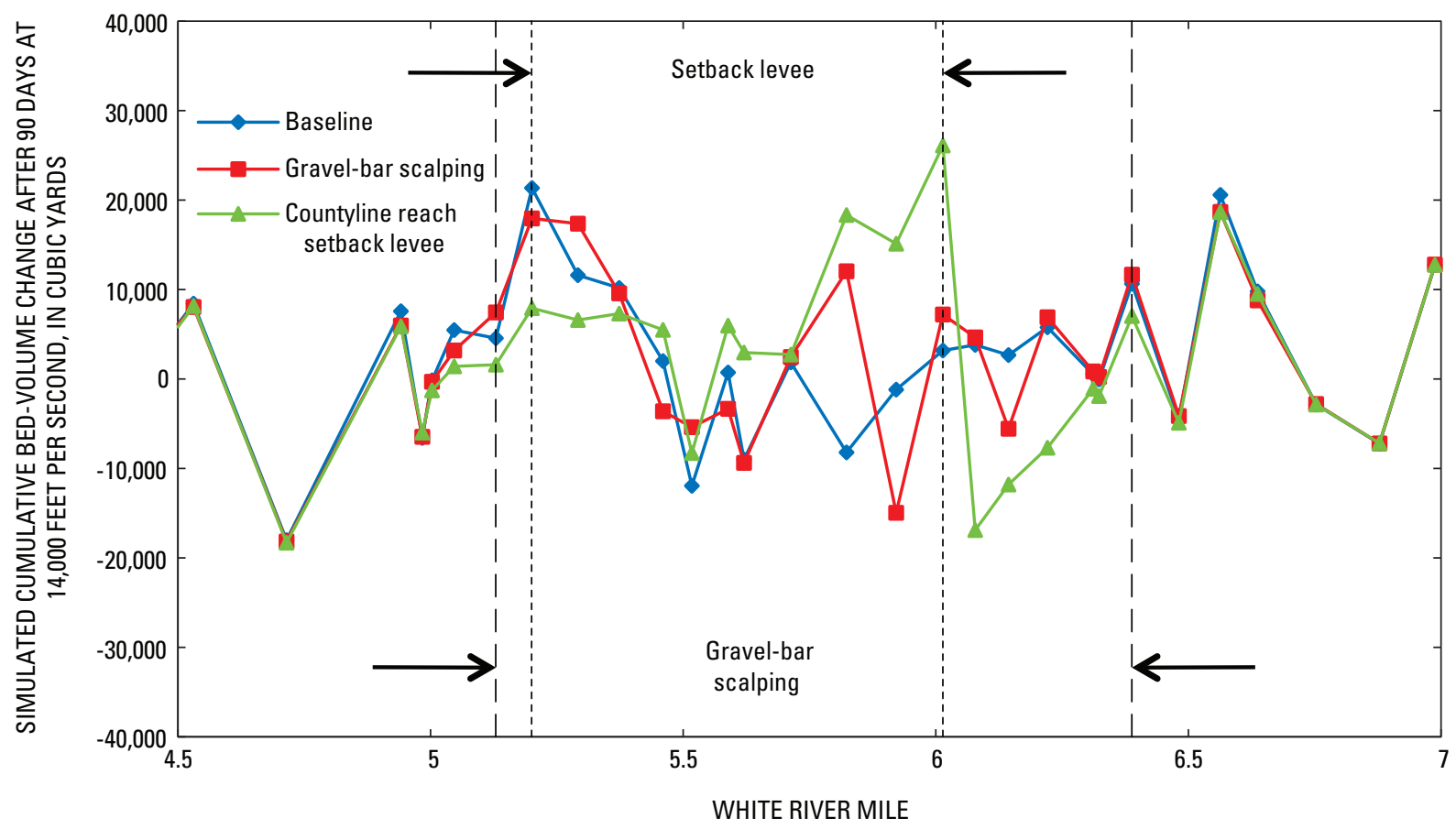

Figure 59. Simulated cumulative bed-volume change after 90 days at a discharge of 14,000 cubic feet per second in the Countyline reach along the White River, western Washington. Model simulation results are best interpreted by qualitatively comparing relative changes between different rivermanagement options.

for the gravel-bar scalping option and 4,000 $\mathrm{yd}^{3}$ for the baseline condition. This would be due to a lower water-surface elevation upstream, which increases flow velocity and sediment-transport capacity. Higher sediment-transport capacity would transport more sediment through a reach of the river, if there is a sufficient sediment supply, otherwise the flow may transport sediment directly from the bed. At the downstream end of the setback-levee section of the Countyline reach, less sediment would deposit for the setback-levee option compared to the gravel-bar scalping or baseline condition; approximately $8,000 \mathrm{yd}^{3}$ of sediment would deposit at RM 5.2 for the setback-levee option compared to approximately $18,000 \mathrm{yd}^{3}$ for the gravel-bar scalping option and $21,000 \mathrm{yd}^{3}$ for the baseline condition. As sediment is transported into the setback-levee section of the Countyline reach, more sediment would deposit immediately for the setback-levee option compared to the gravel-bar scalping option and baseline condition, which would reduce the amount of sediment available to deposit at the downstream end of the reach.

Summing the bed-volume change over the setback-levee Countyline reach each 15 days at a discharge of 14,000 ft $3 / \mathrm{s}$ would result in a constant rate of sediment accumulation in the reach over time (fig. 60). The most sediment would accumulate using the setback-levee option in the Countyline reach compared to the gravel-bar scalping option and the baseline condition; approximately $90,000 \mathrm{yd}^{3}$ after 90 days. The gravel-bar scalping option would accumulate slightly more sediment than the baseline condition in the setback-levee Countyline reach; approximately $30,000 \mathrm{yd}^{3}$ and 20,000 $\mathrm{yd}^{3}$ after 90 days, respectively.

At a discharge of $14,000 \mathrm{ft}^{3} / \mathrm{s}$, the simulated change from the initial water-surface elevation to the water-surface elevation after 90 days of constant flow would show the effect of sediment deposition and erosion in and near the Countyline reach on water-surface elevations for different river-management options at high flows (fig. 61). In the Countyline reach, the change in water-surface elevation for the gravel-bar scalping option would be greater than the baseline condition upstream of RM 5.8 and less than the baseline condition downstream of RM 5.8. The maximum difference in the change in water-surface elevation between the gravel-bar scalping option and the baseline condition would be at RM 5.9, where the water-surface elevation for the gravel-bar scalping option would be increased by approximately $0.9 \mathrm{ft}$ and the baseline condition would be decreased by approximately $0.8 \mathrm{ft}$ compared to the conditions before any simulated sediment transport. This corresponds to a region where a greater amount of sediment would be deposited for the gravel-bar scalping option than for the baseline condition. 


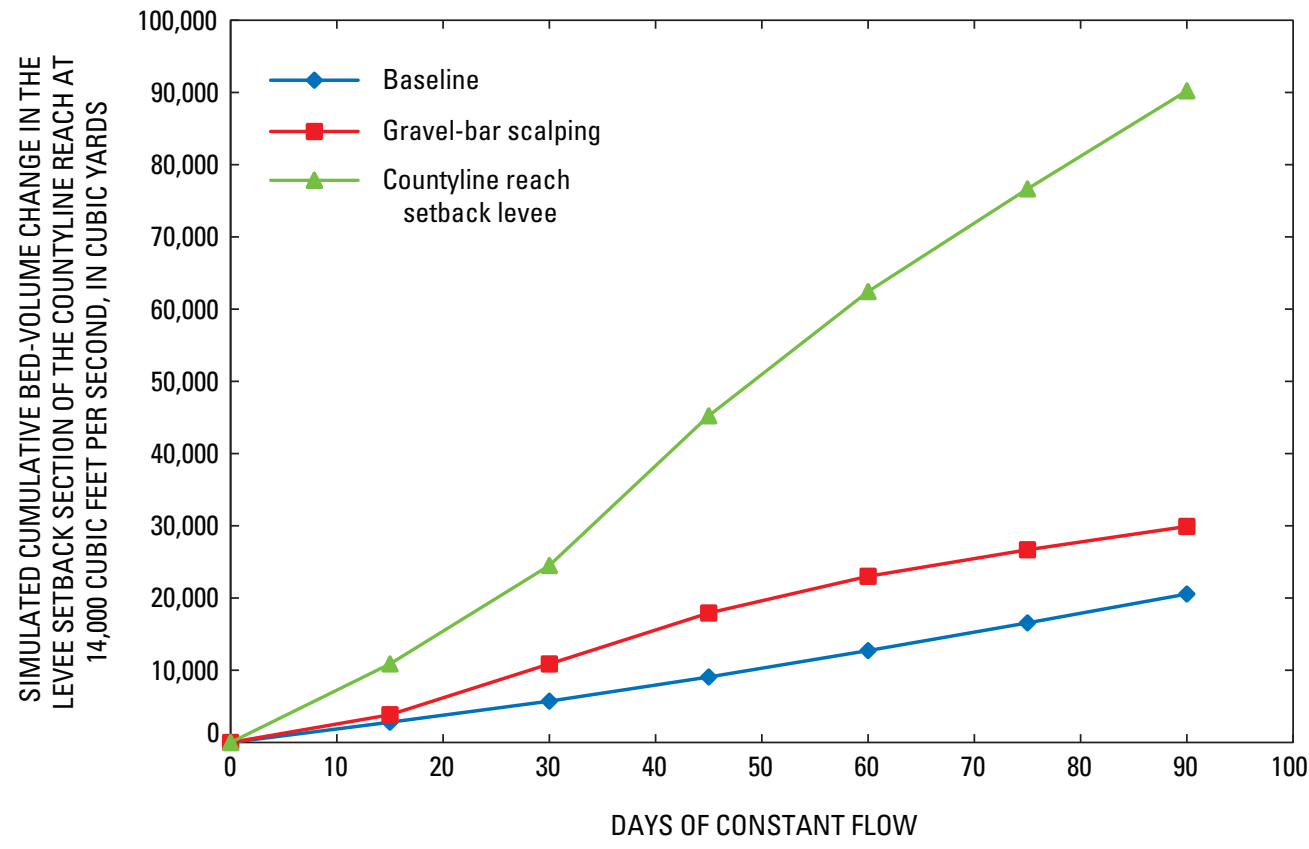

Figure 60. Simulated cumulative bed-volume change at a discharge of 14,000 cubic feet per second for sediment management options in the setback-levee Countyline reach along the White River, western Washington. Model simulation results are best interpreted by qualitatively comparing relative changes between different river-management options.

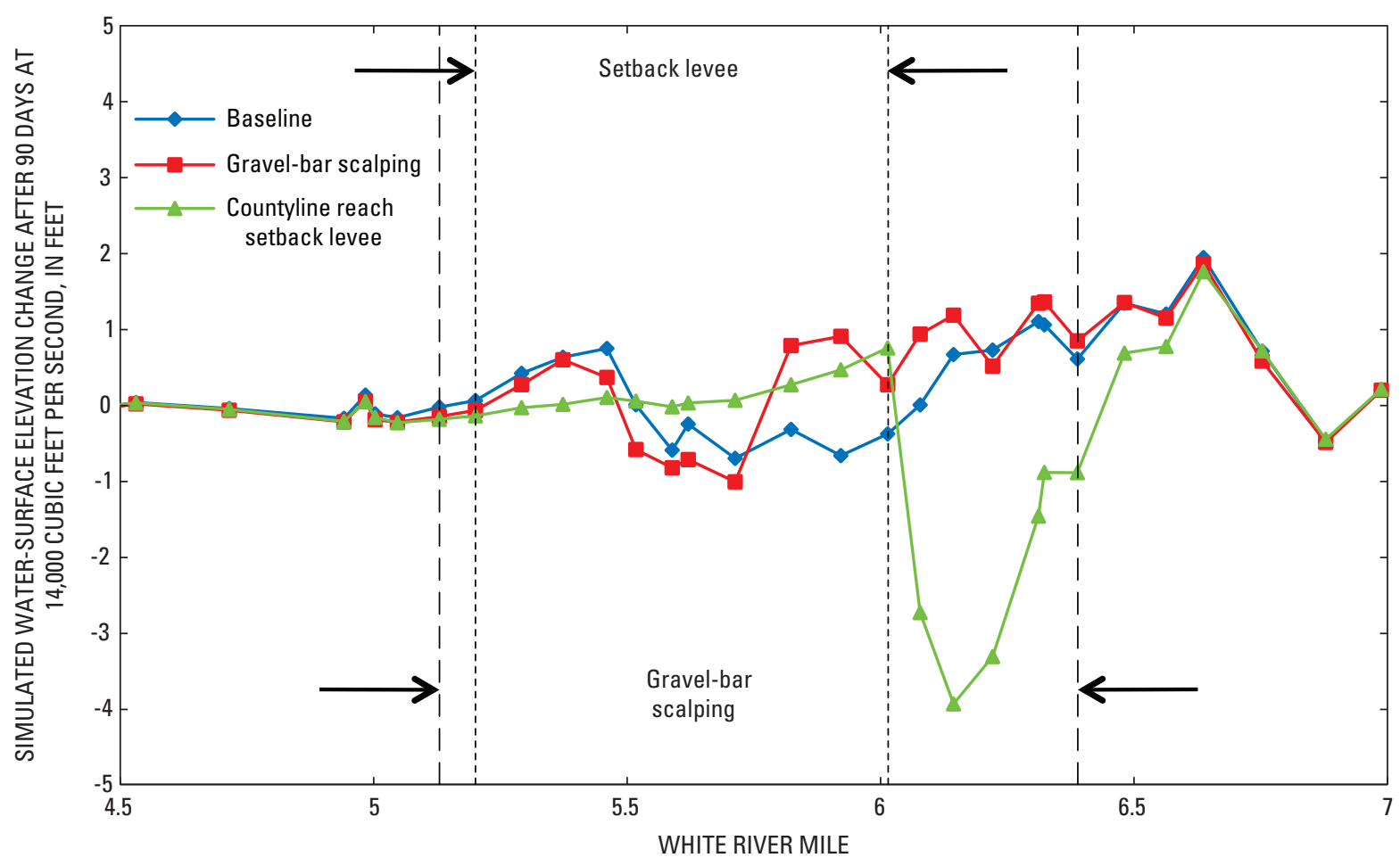

Figure 61. Simulated water-surface elevation change after 90 days at a discharge of 14,000 cubic feet per second for the Countyline reach along the White River, western Washington. Model simulation results are best interpreted by qualitatively comparing relative changes between different river-management options. 
The water-surface elevation for the setback-levee option changed little downstream of RM 5.7. The largest increase in water-surface elevation for the setback-levee option within the setback-levee Countyline reach would be at the upstream end of the reach at RM 6, an increase of approximately $0.8 \mathrm{ft}$ compared to an increase of $0.3 \mathrm{ft}$ for the gravel-bar scalping option and a decrease of $0.4 \mathrm{ft}$ for the baseline condition. Consistent with results from the Calistoga reach, the setback-levee option would deposit a greater volume of sediment in the reach, but the setback-levee option would not have a larger change in high-flow water-surface elevation than the gravel-bar scalping option or baseline condition. Upstream of the setback-levee Countyline reach at RM 6.2, the water-surface elevation would decrease for the setbacklevee option by approximately $4 \mathrm{ft}$, compared to an increase for the baseline condition and the gravel-bar scalping option of approximately 0.7 and $1.2 \mathrm{ft}$, respectively. The large decrease in water-surface elevation for the setback-levee option upstream of the setback-levee Countyline reach, compared to the gravel-bar scalping option and baseline condition, would result from the large amount of sediment that would be transported from this part of the reach.

The annual bed-volume change in the setback-levee section of the Countyline reach was computed for the simulation periods WYs 1999-2003 and 2005-09 (fig. 62).
The sediment accumulation in the setback-levee reach would be greater for the years with high peak discharges (WYs 2005-09) than the years containing relatively low peak flows (WYs 1999-2003). The years of largest sediment accumulation included WYs 2007 and 2009, which included the large November 2006 and January 2009 flow events, respectively. For each year, the sediment accumulation for the setback-levee option would be much larger than the baseline condition or gravel-bar scalping option, and the gravel-bar scalping option would usually be slightly larger than the baseline condition. For example, in WY 2007, the sediment accumulation would be about 7,200 $\mathrm{yd}^{3}$ for the setback-levee option, about $1,700 \mathrm{yd}^{3}$ for the gravel-bar scalping option, and about $1,600 \mathrm{yd}^{3}$ for the baseline condition. In terms of relative magnitudes of sediment deposition for each river-management option, these results are consistent with the results of the continuous-flow simulations described previously. These results also give an indication of the yearly variation in sediment deposition for various flow conditions for each river-management scenario. The volume of sediment deposited during each 5-year period would be well within the amount of sediment deposited at a continuous high flow for 90 days; therefore, the change in water-surface elevation after either 5 -year period would be less than the continuous high flow simulation.

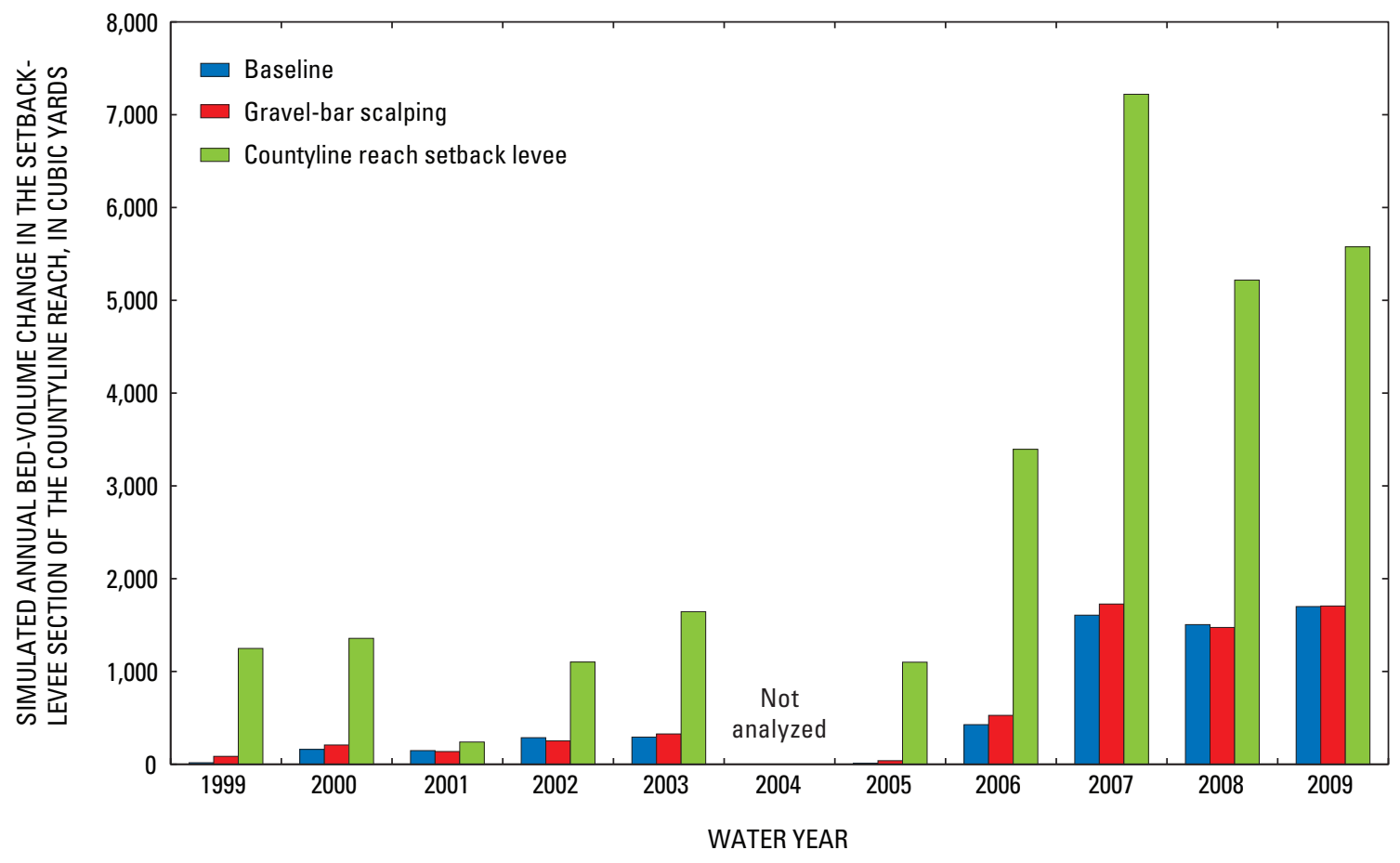

Figure 62. Simulated annual bed-volume change in the setback-levee section for the Countyline reach along the White River, western Washington, water years 1999-2003 and 2005-09, for different river-management options. Model simulation results are best interpreted by qualitatively comparing relative changes between different river-management options. 


\section{River-Management Options for the Puyallup River near Sumner}

The Sumner reach referred to in this analysis is from RM 11.1-11.5, where simulation of a setback levee and existing levee removal affected only the left bank of the reach (fig. 63). The gravel-bar scalping and setback-levee options were simulated along three cross sections, P70, P71, and P72 from RM 11.1 to 11.5. Due to the locations of the cross sections with respect to major gravel bars, the modified channel geometry used for the gravel-bar scalping option simulated the removal of only $1,580 \mathrm{yd}^{3}$ of sediment. The distribution of the existing cross sections in this reach relative to existing gravel bars precluded a realistic simulation of the gravel-bar scalping option.

For the Sumner reach gravel-bar scalping option, essentially no change was detected between this option and the baseline condition (fig. 64); therefore, the combined setback levee and gravel-bar scalping results were omitted from this analysis. The setback-levee option would result in a lower initial water-surface elevation at the upstream end of the Sumner reach; a decrease of approximately $0.9 \mathrm{ft}$ at RM 11.5 compared to the baseline condition. As in the Calistoga and Countyline reaches, increased channel capacity for the setback-levee option would reduce the initial watersurface elevation compared to the baseline condition. At the downstream end of the Sumner reach, the setback levee water-surface elevation would be slightly higher than the baseline condition. The Sumner setback levee at the downstream cross-section would open up a wide floodplain with large roughness. The large roughness would increase the high-flow water-surface elevation slightly compared to the baseline condition. Upstream of the Sumner reach, the water-surface elevation would decrease compared to the baseline condition. The maximum upstream extent of the lowered water-surface elevations would propagate approximately $2.2 \mathrm{mi}$ upstream of the geometric modifications in the Sumner reach. The water-surface elevations upstream of the Sumner reach would be lowered for the setback-levee option because upstream water-surface elevation is controlled from downstream. The extent of the decrease in water-surface elevation upstream would depend on the decrease in watersurface elevation at the upstream end of the reach and on the slope of the channel. Compared to the baseline condition, the lower initial water-surface elevation upstream of the Sumner reach for the setback-levee option would propagate farther upstream than at the other management sites because the channel slope is much lower for the Sumner reach.

The locations of the surveyed cross sections for this study were selected to coincide with those of Prych (1988), and the subsequent hydraulic models were built based on the locations of these cross sections. As a result, the
HEC-RAS model resolution needed to rectify the river response to either management options within or upstream from the Sumner reach was insufficient. Three additional cross sections were surveyed, following the same methods as the 2009 cross sections, by the USGS in August 2010 to improve model resolution and are saved in a data file " 2010 USGS_Additional_Sumner_CrossSections.csv" available for download at http://pubs.usgs.gov/sir/2010/5240/. No further analysis of the river-management options at the Sumner reach is shown.

\section{General Trends and Considerations for River-Management Options}

General conclusions can be drawn from the analysis of the river-management options which provide insight into how flow conveyance and sediment transport would be affected by various river-management options.

Both setback levee and gravel-bar scalping options could reduce high-flow water-surface elevations for the river-management sites considered. Setback levees would reduce the high-flow water-surface elevations within and upstream of the implementation reach by an amount greater than gravel-bar scalping. The setback levees would initially create larger flow areas resulting in lower high-flow water-surface elevations than gravel-bar scalping, which would propagate lower water-surface elevations upstream beyond the setback levee. The decrease in water-surface elevation upstream of a setback-levee reach would propagate farther upstream in reaches with lower channel slopes, and the greater the initial decrease in water-surface elevation, the farther upstream the effect would be noticed.

Analysis of river-management options show reductions in high-flow water-surface elevations within and upstream of the management reaches. Because the analysis included only steady-state hydraulic flow, however, attenuation of flood peaks downstream of setback-levee reaches could not be simulated. During high flows, the floodplain in the setbacklevee reach would be capable of storing water and attenuating flood peaks, which could reduce the magnitude of a flood peak downstream (Archer, 1989; Woltemade and Potter, 1994; Anderson, 2006). Even though the model results show only local reductions in water-surface elevations due to setback levees, flood-peak attenuation could reduce water-surface elevations downstream.

The same input flow and sediment bedload were simulated in the analysis for each river-management option. One of the major differences between the river-management options was the alteration of the spatial distribution of sediment deposition and the effect on flow conveyance. 


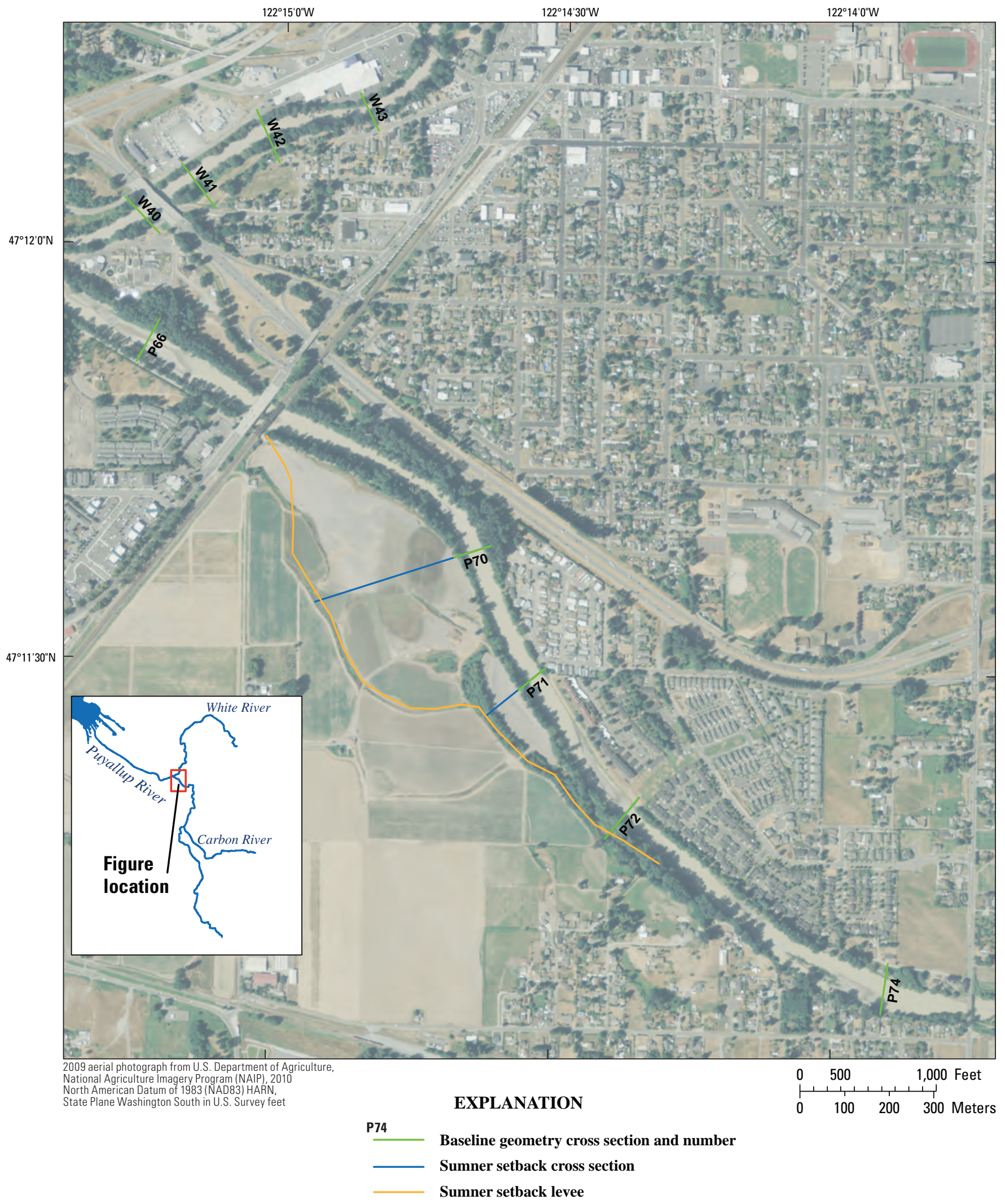

Figure 63. Sumner reach river-management site along the Puyallup River, western Washington. 


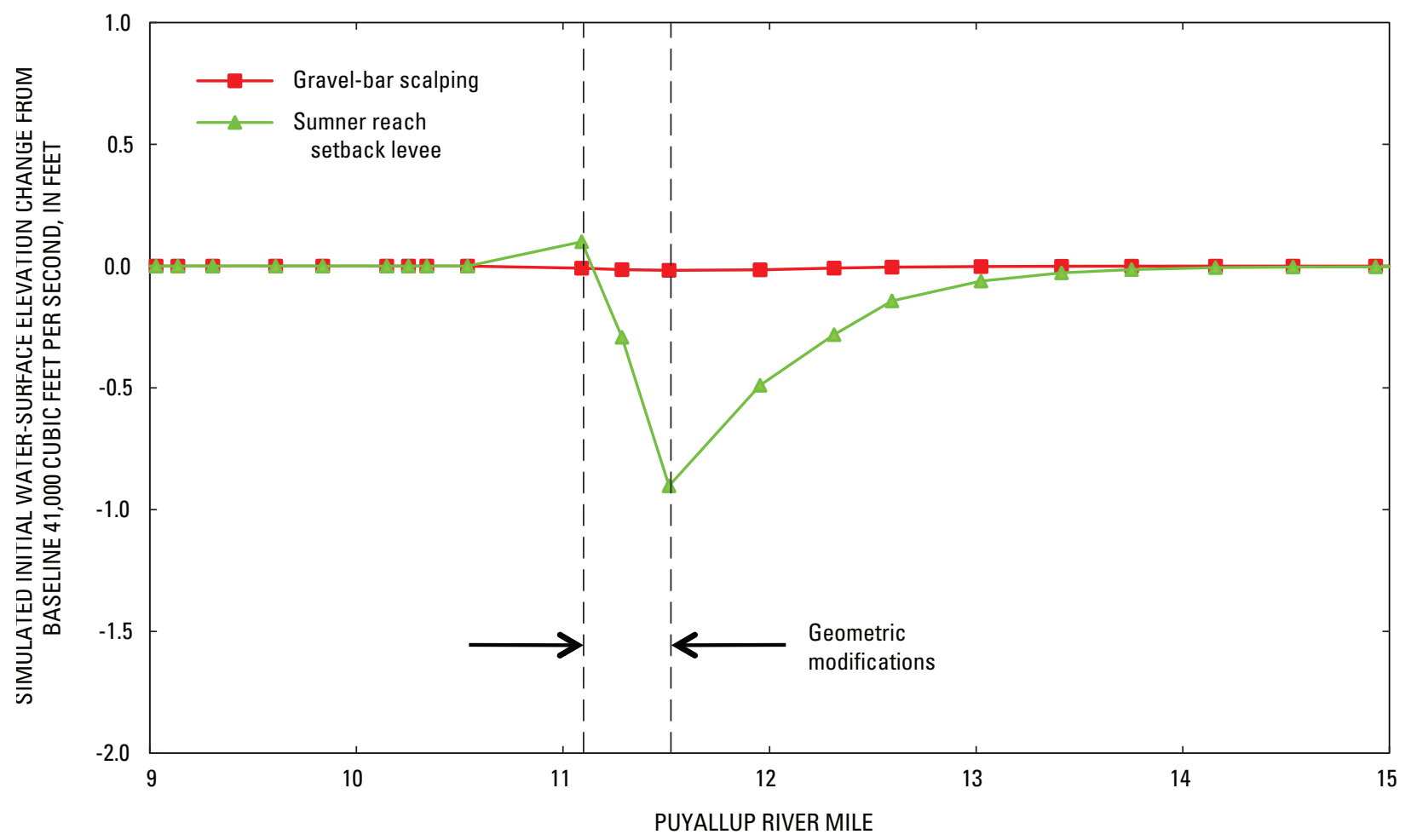

Figure 64. Simulated initial change in the water-surface elevation at a discharge of 43,500 cubic feet per second from management modification relative to the baseline condition for the Sumner Reach along the Puyallup River, western Washington. Model simulation results are best interpreted by qualitatively comparing relative changes between different river-management options.

At the Calistoga and Countyline river-management sites, more simulated sediment would be deposited in the reach for setback levees compared to the gravel-bar scalping. The water-surface elevation for setback levees, however, would be less sensitive to sediment deposition than gravel-bar scalping because the additional floodplain capacity of the setback levee would allow water to spread out and provide a larger area for sediment deposition. As a result, setback levees would provide greater short- and long-term flood protection than the gravelbar scalping option. Generally, gravel-bar scalping would not be as effective as dredging because less sediment by volume is removed through scalping and because the provenance of the removed material is from less-frequent flood events. Scalping removes only the topographically highest deposits in the river (those gravel bars emplaced by infrequent large floods). As a result, scalping removes sediment deposited by the infrequent events and does not directly remove sediment commonly transported during smaller flows. Moreover, setback levees would increase the options available for gravel-removal locations by creating a wider active channel where gravel could be removed away from sensitive aquatic habitat of the river.

\section{Effects of Sedimentation on Flow Conveyance}

By combining the analytical approaches in this study, including cross-section analysis, gaging-station analysis, hydraulic modeling, and sediment-transport modeling, conclusions can be made to explain spatial patterns of reductions in channel-conveyance capacity, effectiveness of river-management options, and the nature of flooding along the White River in 2009.

\section{Sediment Trends Affecting Flow Conveyance}

The channel bed of the Puyallup, White, and Carbon Rivers in the Puget Lowland has aggraded and incised in specific reaches between 1984 and 2009 (fig. 10). Aggradation was more widespread than incision and reaches showing significant aggradation between 1984 and 2009 include the lower Puyallup River downstream of its confluence with the White River, the upper Puyallup River, and the White River between R Street Bridge and the Lake Tapps return (figs. 2 and $\underline{10})$. 
At the four USGS gaging stations in the study area, increases in average channel elevation were accompanied by an increase in stage for a given discharge, a decrease in theoretical overtopping discharge, and a decrease in channelconveyance capacity. Elsewhere in the study area, increases in average channel elevation between 1984 and 2009 were associated with decreases in channel-conveyance capacity between 1984 and 2009. These estimates indicate that flow-conveyance changes have occurred along several reaches of the Puyallup, White, and Carbon Rivers and were mainly due to changes in the channel bed due to aggradation.

The canyons of the Puyallup, White, and Carbon Rivers act as transport zones that convey sediment toward reaches farther downstream. Once these rivers leave their canyons and enter the Puget Lowland, decreased channel slopes result in sediment deposition. Reaches where the simulated bedload decreased in the downstream direction generally corresponded with reaches where the channel-bed elevation increased between 1984 and 2009, indicating that channel-bed aggradation can be explained by sediment-transport patterns.

\section{Effectiveness of River-Management Options}

Decreased channel-conveyance capacity due to channel-bed aggradation would be more effectively mitigated by setback levees than gravel-bar scalping. Setback-levee flow conveyance is less sensitive to sediment deposition than gravel-bar scalping because the additional floodplain capacity would allow water to spread out and provide a larger area for sediment deposition. Constructing setback levees also restores connectivity with the floodplain, provides enhanced flood storage, and improves habitat. Gravel-bar scalping would remove only a small amount of the sediment that has deposited in a particular reach with relatively short-term benefits. Sediment deposition, therefore, would continue where gravel bars are scalped, and future sediment removal would be required to maintain channel-conveyance capacity.

\section{January 2009 Flooding of the White River at Pacific}

After a relatively cold and snowy December, widespread rainfall affected the State of Washington in January 2009. On January 6, 2009, the State began receiving heavy rainfall with high temperatures associated with an "atmospheric river" climatic pattern, consisting of a cold front with strong southwesterly flow aloft and embedded sub-tropical moisture (Schick, 2009). Heavy rainfall continued through January 8 with 3-day totals exceeding $7.5 \mathrm{in}$. at many locations in western Washington (Mastin and others, 2010). Coupled with the warmer temperatures and melting snowpack in the drainage basin, high runoff resulted in flooding of many rivers in western Washington (Mastin and others, 2010).
Releases from MMD early on January 7, 2009, resulted in a discharge of about 8,000 ft $3 / \mathrm{s}$ at the White River near Auburn gaging station (fig. 65). High runoff throughout the Puyallup River drainage basin coupled with forecasted flooding on the lower Puyallup River required the USACE to retain White River runoff in MMD for approximately 24 hours. By retaining water, the USACE limited the peak flow on the Puyallup River (station 12101500) to $48,200 \mathrm{ft}^{3} / \mathrm{s}$ on January 8, 2009, thereby prevented widespread flooding along the lower Puyallup River. After high discharge in the Puyallup River abated, water was released from MMD in anticipation of more rainfall. On January 8 , sustained discharge at the White River near Auburn gaging station increased to more than 11,500 $\mathrm{ft}^{3} / \mathrm{s}$ from 6:30 PM, January 8, until 9:30 PM, January 9. The peak discharge of $12,000 \mathrm{ft}^{3} / \mathrm{s}$ occurred at 12:45 PM on January 9. After the USACE aerial inspection of flooding in Pacific, the releases from the dam were reduced, which stopped the overtopping of levees in Pacific. Discharge at the Auburn gaging station remained between 9,000 ft $3 / \mathrm{s}$ and 10,000 ft $\mathrm{ft}^{3} / \mathrm{s}$ until January 13 (fig. 65).

In January 2009, a high-discharge event overtopped levees at several locations along the White River in King and Pierce Counties causing extensive flooding and damage. Although some degree of flooding occurred on both sides of the river, most of the damage was along the right bank from RM 6.0 to RM 3.5 (figs. A10-11). Along the right side of the river, floodwaters pushing into Pacific City Park near RM 6.0 flowed south and parallel to the river and inundated residential neighborhoods in the City of Pacific, Wash. (U.S. Army Corps of Engineers, 2009). Flood waters also affected homes and commercial development in Pierce County behind the right bank from RM 5.5 to RM 5.0 and from RM 4.3 to RM 3.5 (figs. A10-11) (Todd Essman, Pierce County, written commun., 2010). Widespread flooding also occurred behind the left bank from RM 5.7 to near RM 2.0, although fewer structures were affected due to predominance of agricultural land use and undeveloped open space.

The most prominent and farthest upstream location of bank overtopping occurred on the right bank at RM 6.0 (Pacific City Park), but right-bank overtopping occurred at several locations along the river channel in King County between RMs 5.8 and 5.4 (Jim Morgan, City of Pacific, written commun., 2010). Farther downstream, aerial photographs taken from a helicopter by the USACE on the morning of January 9, 2009, showed overtopping of the right bank at RM 4.5 and RM 4.3. The aerial photographs showed a hydraulic connection between water in the right-bank floodplain and the main channel from RM 4.5 to RM 3.5; however, it is not clear if this connection represented return flow from the floodplain to the channel or actual river-bank overtopping. Based on these observations, two river reaches where bank overtopping occurred were identified as along the right bank from RM 6.0 to RM 5.3 and from RM 4.5 to RM 4.3. 

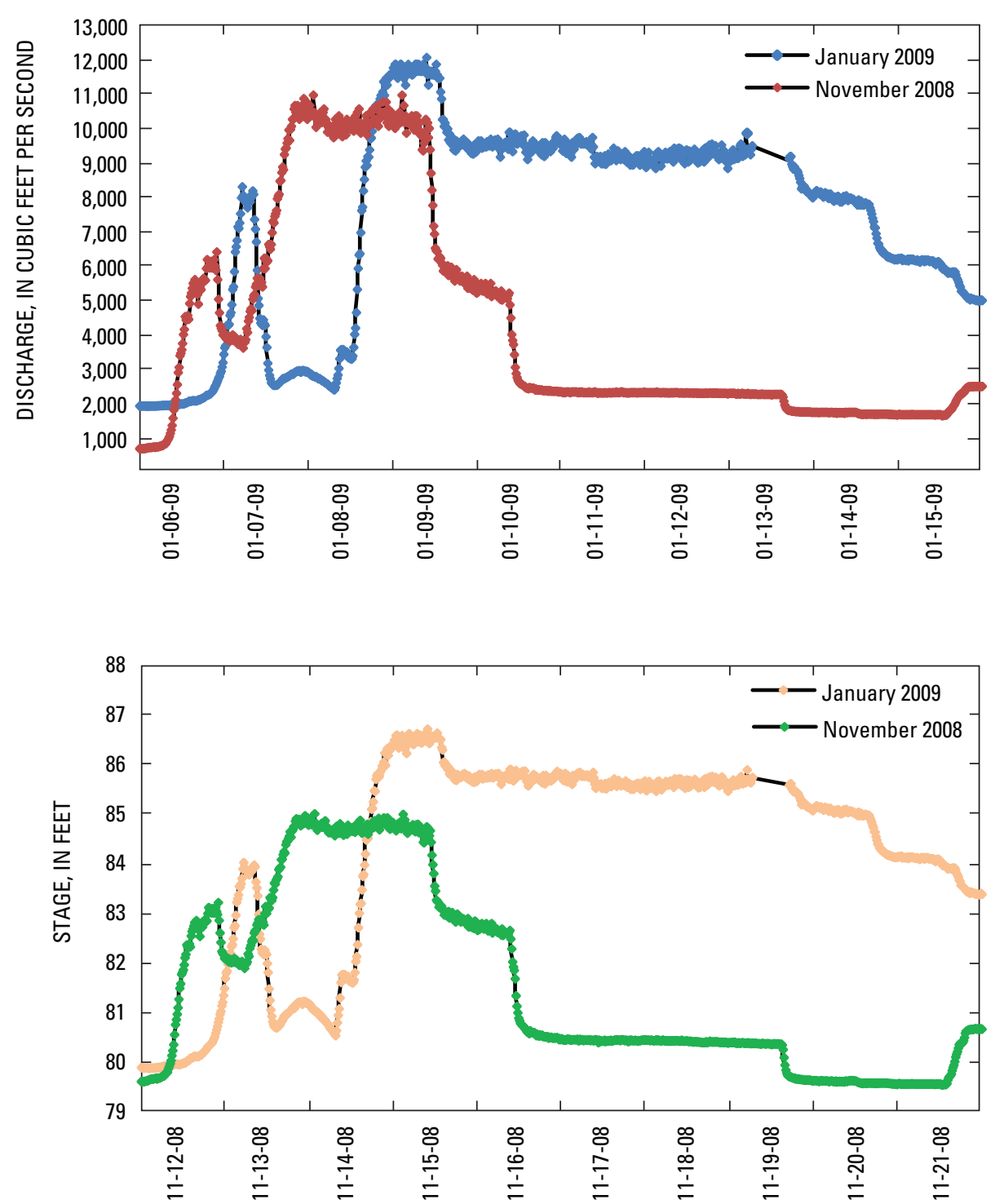

Figure 65. Comparison of $(A)$ discharge and $(B)$ stage for the White River near Auburn for 10-day periods starting November 12, 2008 and January 6, 2009.
In contrast, similar releases from MMD two months earlier, November 13-15, 2008, resulted in discharge readings ranging from $9,670 \mathrm{ft}^{3} / \mathrm{s}$ to $10,900 \mathrm{ft}^{3} / \mathrm{s}$ at the Auburn gaging station (fig. 65) and caused only "nuisance" flooding of mostly undeveloped lands downstream (U.S. Army Corps of Engineers, 2009). The USACE also built a low dirt berm in Pacific City Park on January 13 after overbank flows in the park returned to the river channel. The different overtopping responses to two otherwise similar released discharges raised the question of what changed in the river channel between November 2008 and January 2009.

Stage was recorded during the peak flows in November 2008 and January 2009 at gaging station 12100496, White River near Auburn (fig. 65). Notably, the measured stage in January 2009 was about $1 \mathrm{ft}$ higher than the measured stage in November 2008 for comparable discharge values (fig. 65). Surging of the water surface at this site, prominent at larger discharge, adds an uncertainty of $\pm 0.08 \mathrm{ft}$ in reported stage for discharge between 9,000 and 12,000 ft³/s (Mark Bryant, U.S. Geological Survey, written commun., 2010), but the difference in reported stage for similar discharge over the 2-month period is much larger than uncertainty in the instrument reading. Moreover, surveyed high-water marks in the gage house confirmed the reported peak stage from the transducer for both the November and January peak discharges.

Discharge recorded from the gaging station is calculated using the most up-to-date stage-discharge rating curve. Due to safety issues with measuring from bridges close to the gaging station, discharge measurements for station 12100496 are made $4.6 \mathrm{mi}$ downstream at the Tacoma Avenue Bridge and then corrected for time of travel and return flow from Lake Tapps (station 12101100, Lake Tapps diversion at Dieringer). Because releases from MMD typically are constant for long periods, discharge measurements made downstream reasonably represent discharge conditions at the gaging station with the appropriate corrections. Discharge measurements 
were made on November 14, 2008, during the first peak discharge, on January 9, 2009, during the high discharge that led to flooding, and on January 13, 2009, when discharge was about $9,000 \mathrm{ft}^{3} / \mathrm{s}$ after the peak discharge. These three discharge measurements (plus subsequent measurements at lower discharge) documented a rapid change in the stagedischarge relation at the Auburn gaging station whereby water-surface elevations for discharges between 9,000 and $12,000 \mathrm{ft}^{3} / \mathrm{s}$ were $1.3 \mathrm{ft}$ higher than previous stages for the same discharge (fig. 36). In turn, the channel-conveyance capacity at the gaging station decreased 25 percent during those 2 months (fig. 35). Although downstream reduction in channel capacity between November 2008 and January 2009 cannot be determined where levee overtopping occurred, it is reasonable to assume that some channel-conveyance reduction also occurred in the river reach downstream of the gaging station.

Juxtaposing the location of bank overtopping against the 25-year changes in channel elevation (ig. 66) and the reduction in channel-conveyance capacity as determined by modeling (fig. 41) shows the strong spatial correlation between bank overtopping and long-term sediment aggradation in the White River (fig. 66). For example, the river reach between RMs 5.3 and 6.0 is collocated with the maximum change in elevation measured between 1984 and 2009 (fig. 66).

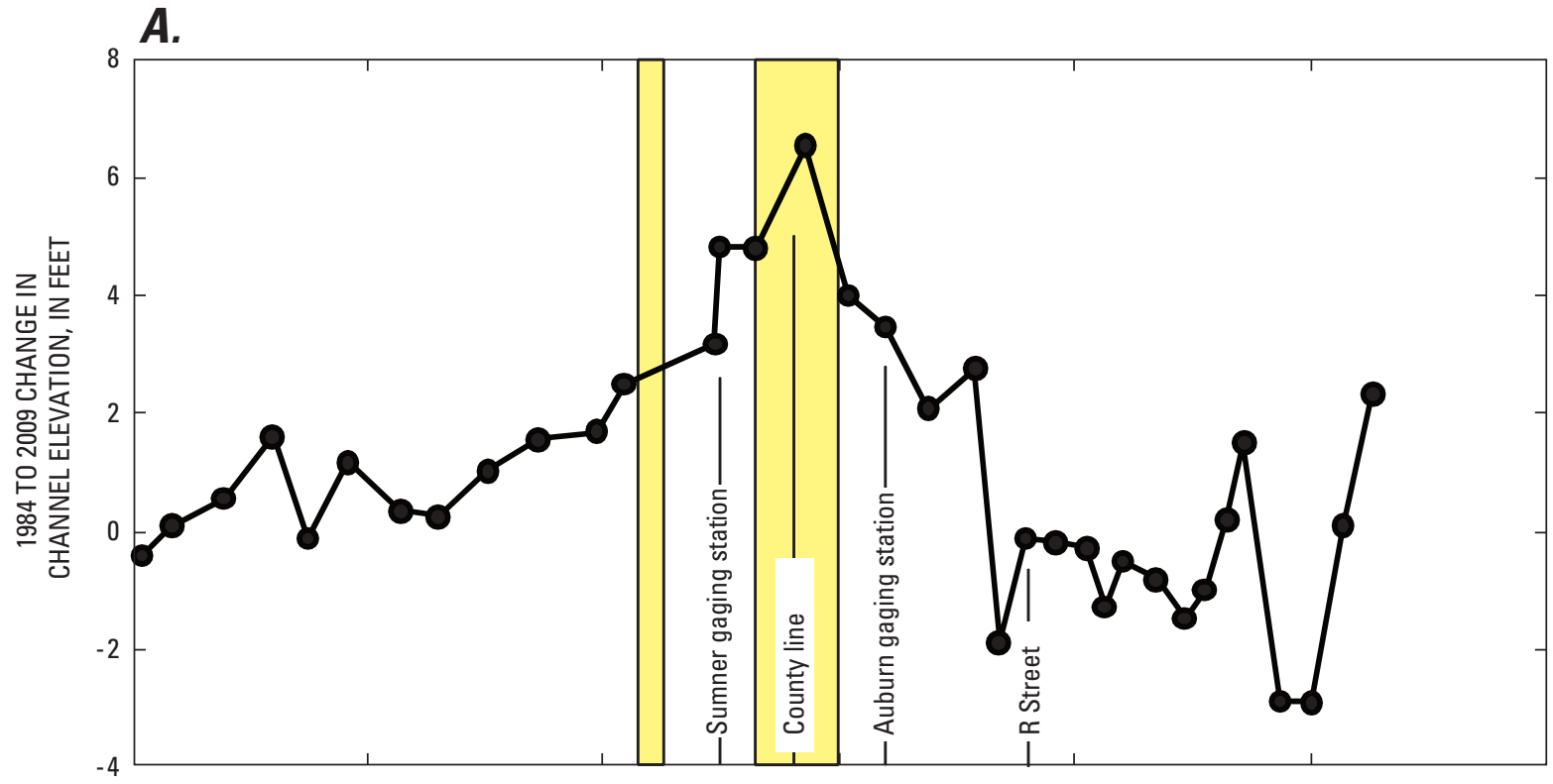

B.

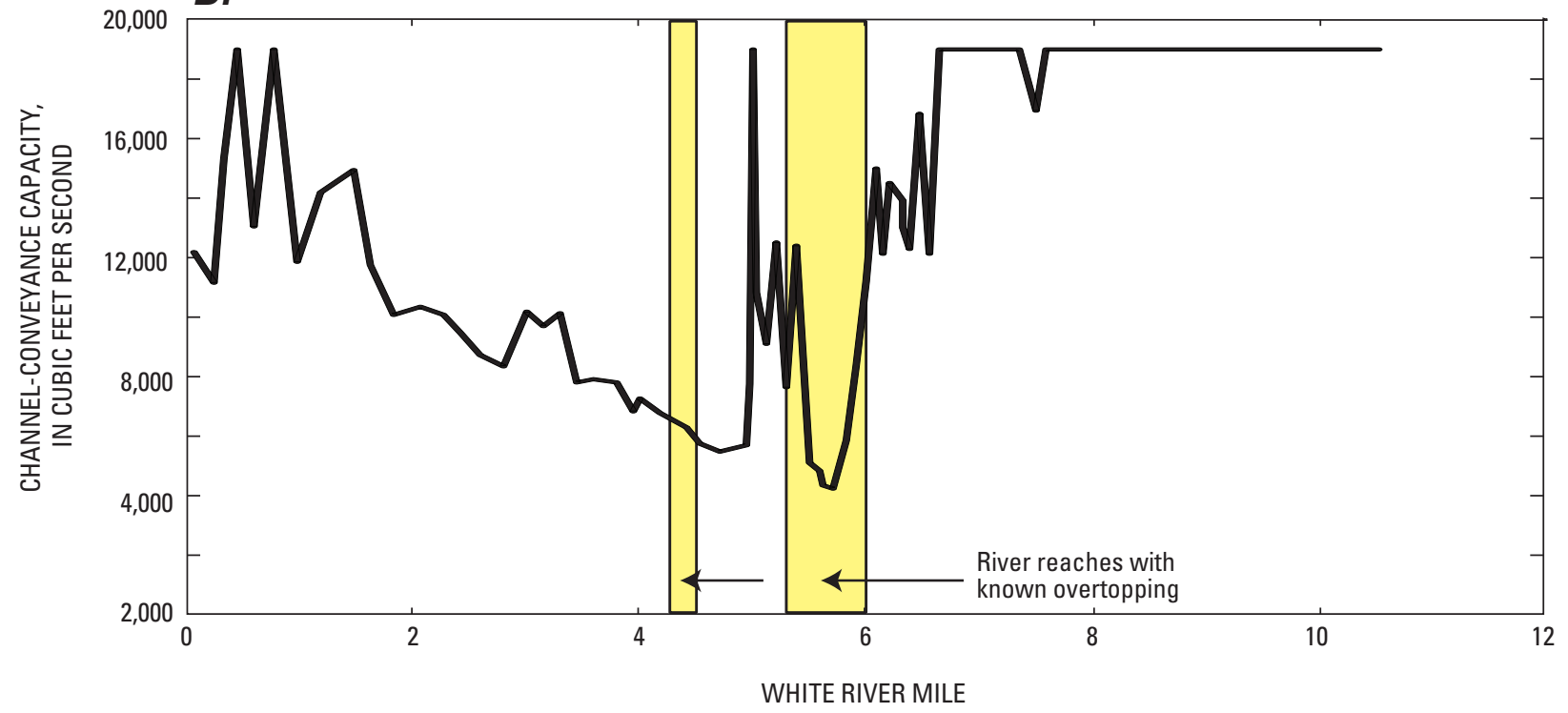

Figure 66. Changes in $(A)$ mean channel elevation between 1984 and 2009 for surveyed cross sections, and $(B)$ channel-conveyance capacity determined with one-dimensional hydraulic modeling for the White River near Auburn, Washington. Yellow shading indicates reaches where levees were overtopped during the January 2009 peak discharge. 
Hydraulic modeling also shows that this section of the river is the most compromised with respect to relative bank height and overall channel-conveyance capacity. Less overall aggradation has occurred in the second reach of overtopping between RMs 4.3 and 4.5, but the channel-conveyance capacity here is similarly small. The overtopping of the right bank at this location is also on the outside of a river bend and superelevation of the water surface on the outside of the bend, which is not simulated in the hydraulic model, may have intensified overtopping.

Several factors can, in theory, reduce channel conveyance, including increased vegetation and the accumulation of coarse-grained sediment leading to aggradation and higher water surfaces. The U.S. Army Corps of Engineers (2009) reported encroaching vegetation in some reaches of the White River since the 1980s, particularly near the King-Pierce County line, that reduced conveyance. Sensitivity analysis of the hydraulic model to increasing bank roughness in the section of the White River from RM 5.0 to RM 5.5 (fig. 44) indicates the possibility of reduced channel-conveyance capacity with vegetation growth. Also, collections of large woody debris, which were not analyzed in this report, could temporarily create backwater conditions leading to overtopped levees. Nonetheless, the reduced channel-conveyance capacity at the gaging station between November 2008 and January 2009 can be attributed to aggradation of coarse-grained alluvium in the river channel because no new significant vegetation grew in the winter months between November and January. Additionally, changes in the rating curve for the White River near Auburn gaging station since the 1980s occurred in a step-wise fashion, usually in response to discharges (iggs. 26 and $\underline{36}$ ) rather than gradually over time. This pattern indicates that most changes in conveyance capacity at the gaging station, even for high flows, were predominantly responses to alluvial aggradation.

The current conditions of the White River, as represented in figure 66, reflect the geomorphic state of the river following the peak event in January 2009. Additionally, the region of fresh sediment deposition in the river channel probably will prograde downstream with future high discharges, which may cause the reaches downstream from the county line to become more prone to overtopping. These downstream reaches should be monitored during high discharges because the river displays the dynamic ability to change quickly. These reaches also should be monitored between flood seasons to detect changes in channel morphology that could compromise channel-conveyance capacity.

\section{Need for a Sediment Budget}

Accurate sediment-transport modeling requires detailed boundary conditions describing sediment input, distribution, and caliber. Such data are limited for the Puyallup River system. The best sediment-transport data were collected between the 1960s and 1980s, and even those data were only collected periodically. In addition to improving sediment-transport modeling, complete sediment data sets are fundamental to quantifying the sediment budget for the river network draining Mount Rainier as well as monitoring sedimentation trends in Puget Lowland rivers. Although direct sediment-load measurements (suspended load and bedload) give a direct measure of sediment transport, collecting the required number of measurements over the range of flows needed to capture the full variability of the sediment transport process can be cost prohibitive. New monitoring technologies that record turbidity, acoustic backscatter, and laser diffraction (Gray and Gartner, 2009) offer the ability to collect high-quality sediment-load data at a significantly reduced cost. These new technologies are not only less expensive than traditional methods, but they can also collect data continuously. Monitoring sediment load with these newer techniques would greatly improve the understanding of sediment movement throughout the Puyallup River system.

In the absence of detailed sediment monitoring, the use of geomorphic principles, computer modeling, and an estimate of the volume of sediment from Mount Rainier can be used to generate a qualitative sediment budget for the Puyallup River network. Additionally, identifying sediment sources and sinks throughout the river network and predicting how these locations may change in time due to glacial retreat and larger hydrologic events would give a comprehensive understanding of the factors governing sedimentation. More importantly, such a geomorphic analysis would begin to answer the question of how the sedimentation rate might change through time in response to different climatic conditions. Furthermore, understanding how sediment is transported from high in the drainage basin to the lowland rivers offers important insight when explaining observations of geomorphic change downstream. The timescale associated with sediment transport and channel adjustment is long and strongly coupled to sediment-input conditions (Vries, 1975). Sediment pulses introduced to the Puyallup, White, or Carbon Rivers in reaches far upstream, either through landslides or erosion of recently exposed glacier moraines, may take decades to move downstream (Benda and Dunne, 1997; Beechie, 2001; Cui and others, 2003). However, the actual travel time of bedload sediment for these rivers is unknown. Understanding the type of hydrologic events that supply sediment to the river network and transport the sediment downstream is important to predicting when and how much sediment could arrive in lowland reaches. 


\section{Summary}

The U.S. Geological Survey (USGS) found regions of significant aggradation along the Puyallup and White Rivers by surveying bathymetric and topographic data for 156 cross sections in the lower Puyallup River system in 2009 and comparing the results with similar data collected in 1984. Accuracy of the comparative analysis was limited to about $1.0 \mathrm{ft}$; nonetheless, aggradation of as much as $3.5 \mathrm{ft}$ was measured in the Puyallup River just downstream of its confluence with the White River. A reach of the Puyallup River upstream of the confluence with the Carbon River (River Mile [RM] 18.4 - 24.8) aggraded by more than $2 \mathrm{ft}$ with four cross sections showing aggradation greater than $4 \mathrm{ft}$. The largest measured aggradation (7.5 ft) was in the Puyallup River at RM 23.3. The largest volume of deposited sediment in the Puyallup River was in the upper Puyallup River with a 25-year (1984-2009) total net volume of deposition between the confluence with the Carbon River and the Calistoga Bridge (RM 17.7-21.5) of approximately $429,000 \mathrm{yd}^{3}$, $17,200 \mathrm{yd}^{3} / \mathrm{yr}$, or $4,500 \mathrm{yd}^{3} / \mathrm{yr} / \mathrm{RM}$ and between the Calistoga Bridge and USGS streamflow-gaging station 12093500, Puyallup River near Orting (RM 21.5-25.7), of approximately $907,000 \mathrm{yd}^{3}, 36,300 \mathrm{yd}^{3} / \mathrm{yr}$, or $8,600 \mathrm{yd}^{3} / \mathrm{yr} / \mathrm{RM}$. The reach with the largest volume of deposition in the Puyallup River (RM 21.5-25.7) corresponded to the setback-levee reaches, the 1998 Ford-Hatten-Filbin setback levee between RM 23.4-25.0 and the 2006 Soldiers' Home setback levee between RM 21.5-22.4. Finally, pronounced aggradation, as much as $6.5 \mathrm{ft}$, was measured in the White River near the county line between R Street Bridge and the Lake Tapps return (RM 4-7), a river reach subject to recent flooding. The largest 25 -year (1984-2009) total net volume of sediment of approximately $547,000 \mathrm{yd}^{3}, 21,900 \mathrm{yd}^{3} / \mathrm{yr}$, or $5,900 \mathrm{yd}^{3} / \mathrm{yr} / \mathrm{RM}$ was deposited in the White River between the Lake Tapps return and the R Street Bridge (RM 3.9-7.6).. These aggrading river reaches correlated with decreasing slopes in riverbeds where the rivers exit relatively confined sections bounded by bedrock and glacial till and enter the relatively unconstricted valleys of the low-gradient Puget Lowland. Measured grain-size distributions from each riverbed showed a progressive fining downstream. The general downstream decrease in the bed-material grain-size most likely is due to downstream fining by selective deposition in addition to attrition.

Analysis of stream-gaging data from 12 long-term USGS gaging stations in the greater Mount Rainier drainage basin demonstrated the dynamic nature of channel morphology on river courses influenced by glaciated, volcanic terrain. Over the past three decades, some gaging records demonstrated strong trends of incision, some showed strong trends in aggradation, and some showed incision and aggradation. The greatest rates of aggradation since the 1980s were in the Nisqually River near National (5.0 in/yr) and the White River near Auburn (1.8 in/yr); a previous study found the aggradation rate for the White River near Sumner, just downstream from Auburn, to be a comparable 1.9 in/yr. Less pronounced aggradation was measured along the reaches of the lower Puyallup River, the upper Puyallup River near Electron, and the White River near Buckley just downstream of Mud Mountain Dam. The largest measured rate of incision was measured in the Cowlitz River at Packwood (5.0 in/yr). Overall, the data indicated that late-20th-century trends in documented aggradation downstream of Mount Rainier have continued to the present (2009).

Using a one-dimensional hydraulic model, estimated channel-conveyance capacity based on river geometry surveyed in 2009 has decreased in some river reaches since 1984. The reach exhibiting the largest decrease in channel-conveyance capacity was the White River from about RM 2 to RM 7 where capacity has decreased about 20-50 percent. Conveyance capacity also decreased on the Puyallup River near the confluence with the White River and on the Puyallup River upstream of the Carbon River. Conveyance capacity remained largely unchanged along other reaches including the middle Puyallup and Carbon Rivers where accumulated sediment has not decreased the channel-conveyance capacity to less than the maximum discharge simulated.

Using the same hydraulic model, bedload transport was simulated throughout the entire river network. Consistent with observations and analyses showing general trends of aggradation, the bedload-transport component of the hydraulic model showed that the upper Puyallup and White Rivers tended to accumulate sediment for a simulation of five small-discharge water years (WY; WYs 1999-2003) and five large-discharge water years (WYs 2005-2009). The accuracy of the bedload-transport modeling, however, was limited by few sediment-transport data sets from the Puyallup River system, mantling of sand over cobbles in the lower Puyallup and White Rivers, and overall uncertainty in simulating sediment transport in gravel-bedded rivers. Consequently, the results from the model were treated as qualitative in value, useful for comparing geomorphic trends in different river reaches but not accurate for producing precise predictions of mass of sediment moved or deposited. One limitation of the bedload-transport modeling approach was the size and complexity of the entire model.

The hydraulic model and its bedload-transport component were useful in analyzing proposed river-management options, provided that surveyed cross sections adequately represented the river-management site and proposed management options. The simulated river-management options at the county line contained the largest number of modified cross sections and produced the most useful results. The simulated river-management options at the Calistoga reach produced results that were of sufficient resolution to provide analytical insight, but uncertainties remained. The model results for proposed river-management options near Sumner were of limited use because the model contained only three modified cross sections and no definitive conclusions could be drawn. As was the case when modeling the entire river system, the bedload-transport model-simulation results were best 
when used to analyze qualitative trends of accumulation and hydraulic response to different management options. The model was limited in accuracy, such that quantitative estimates of the volume and timing of sediment accumulation or deposition following a particular river-management change were indeterminate. Due to limitations of available data sets and sediment-transport equations, the hydraulic model could not be used to evaluate the useful expected lifetime of a particular river-management option.

Nevertheless, the hydraulic model showed that setback levees would provide greater flood protection than gravel-bar scalping immediately after project implementation and for a significant time thereafter. The greatest hydraulic benefit of setback levees would be a substantial increase in the effective channel-conveyance area. By widening the distance between levees and enabling a flood peak to spread over a larger area, the new floodplain would accommodate large increase in discharge with relatively small increases in stage. The hydraulic benefit from a setback levee also would be long-lived, effectively compensating for increased deposition in the setback reach from increased channel-conveyance capacity. In contrast, gravel-bar scalping would be limited hydraulically in three fundamental ways. First, regulatory requirements force gravel removal from only the top of bars, which are deposits emplaced during the largest and most geomorphically significant floods. As a result, scalping would not remove sediment deposited by smaller floods, and gravel-bar scalping alone would not remove the volume of sediment required to fully restore channel conveyance. Second, scalping would increase the effective channelconveyance area by only a relatively small amount. And third, gravel-bar scalping would not alter the underlying hydraulics of the river channel. A gravel-bar-scalped river in a channel reach confined by closely spaced levees or revetments would remain sensitive to large responses in stage with increasing discharge and continue to be prone to future sediment accumulation.

The study used the change analysis, gaging-station data, and the hydraulic model-simulation results to formulate an explanation of the flooding that affected the City of Pacific, Washington, in January 2009. Data from this study indicate the reduction in channel-conveyance capacity of about 25 percent at the White River near Auburn gaging station (12100496) between November 2008 and January 2009 was caused by rapid aggradation of coarse-grained sediment downstream of the gaging station. Additionally, changes in the rating curve for the White River near Auburn gaging station since the 1980s occurred in a step-wise fashion, usually in response to large-discharge events rather than gradually over time, indicating most changes in conveyance capacity at this gaging station, even for higher flows, were predominantly responses to alluvial aggradation. The channel response of the lower White River represents an ongoing trend of aggradation that has been documented repeatedly. Additionally, it seems that this region of aggradation is prograding downstream, and could increase flooding risk downstream of the county line.

\section{Acknowledgments}

Sarah Motsenbocker (Pierce County Public Works and Utilities, Surface Water Management) collected and organized historical gravel-removal data. Terry Butler (King County Department of Natural Resources and Parks, Water and Land Resources Division) and Karl Eriksen (U.S. Army Corps of Engineers) provided analytical insight and feedback during the study and also provided data describing 2009 flooding on the White River. Todd Essman (Pierce County Public Works and Utilities, Surface Water Management) provided data describing 2009 flooding on the White River. Randy Brake (Pierce County Public Works and Utilities, Surface Water Management), Lorin Reinelt (Pierce County Public Works and Utilities, Surface Water Management), and Patrick Reynolds (Muckelshoot Indian Tribe) all provided analytical insight and feedback during the study. The U.S. Army Corps of Engineers and King County provided data for use in this study. Emily Sheu, U.S. Geological Survey, was instrumental in both collecting field data for the project and analyzing gaging-station data. Shan Rayray, U.S. Geological Survey, worked tirelessly with databases and archived files to query and assemble historical streamflow-gaging station data. Brietta Carter, U.S. Geological Survey, helped with collecting field data.

\section{References Cited}

Ackerman, C.T., 2009, HEC-GeoRAS GIS tools for support of HEC-RAS using ArcGIS user's manual: U.S. Army Corps of Engineers CPD-83, 193 p.

Anderson, B.G., 2006, Quantifying the interaction between riparian vegetation and flooding from cross-section to catchment scale: Victoria, Australia, University of Melbourne, Ph.D. dissertation, 529 p.

Archer, D.R., 1989, Flood wave attenuation due to channel and floodplain storage and effects on flood frequency, in Beven, K., and Carling, P., eds., Floods-Hydrological, sedimentological, and geomorphological implications: New York, Wiley, p. 37-46.

Bauer, Travis, 2009, Puyallup historical cross section comparison: Bureau of Reclamation Report SRH-2009-11, $21 \mathrm{p}$.

Beason, S.R., 2007, The environmental implications of aggradation in major braided rivers at Mount Rainier National Park, Washington: Cedar Falls, Iowa, University of Northern Iowa, M.S. thesis, 165 p. 
Beechie, T.J., 2001, Empirical predictors of annual bed load travel distance, and implications for salmonid habitat restoration and protection: Earth Surface Processes and Landforms, v. 26, no. 9, p. 1025-1034.

Benda, Lee, and Dunne, Thomas, 1997, Stochastic forcing of sediment routing and storage in channel networks: Water Resources Research, v. 33, no. 12, p. 2865-2880.

Bountry, J.A., and Piety, L.A., 2009, Geomorphic and sediment analysis of levee impacts along the Puyallup River from Calistoga bridge (river mile 21.3) upstream to the high bridge (river mile 25.2): Memo 86-68240, RES-3.10 to Puyallup Tribe, $17 \mathrm{p}$.

Breed, C.B., 1916, Surveying, geodesy, railroad location: earthwork computations, in Mansfield, M., ed., American civil engineers' pocket book: New York, Wiley, p. 133-150.

Brunner, G.W., 2008a, HEC-RAS version 4.0, river analysis system hydraulic reference manual: U.S. Army Corps of Engineers CPD-69, 411 p.

Brunner, G.W., 2008b, HEC-RAS version 4.0, river analysis system user's manual: U.S. Army Corps of Engineers CPD-68, 733 p.

Collins, B.D., and Dunne, Thomas, 1989, Gravel transport, gravel harvesting, and channel-bed degradation in rivers draining the southern Olympic Mountains, Washington, U.S.A.: Environmental Geology, v. 13, no. 3, p. 213-224.

Copeland, E.A., 2009, Recent periglacial debris flows from Mount Rainier, Washington: Corvallis, Oreg., Oregon State University, M.S. thesis, 124 p.

Cui, Yantao, Parker, Gary, Pizzuto, J.E., and Lisle, T.E., 2003, Sediment pulses in mountain rivers 2: comparison between experiments and numerical predictions: Water Resources Research, v. 39, no. 9, p. 1240.

Dally, J.W., Riley, W.F., and McConnell, K.G., 1984, Instrumentation for engineering measurements: New York, Wiley, 576 p.

Dunne, Thomas, 1986, Sediment transport and sedimentation between RMs 5 and 30 along the White River, Washington: Bellevue, Wash., Report prepared for Puget Sound Power and Light Company, 39 p.

Einstein, H.A., 1950, The bed load function for sediment transportation in open channels: Soil Conservation Service Technical Bulletin 1026, 71 p.

Entrix, 2008, Final technical memorandum-Topographic survey, hydraulic modeling and design assessment of proposed Carbon River Road flood damage reduction measures: Seattle, Wash., Entrix, Project \#4194803, 48 p.
Entrix, 2009, Mount Rainier National Park flood mitigation and Longmire and Sunshine Point: Project description: Seattle, Wash., Entrix, 87 p.

Federal Emergency Management Agency, 2007, Flood insurance study, Pierce County, Washington: Federal Emergency Management Agency Flood Insurance Study 53053CV001A, v. 1, 196 p.

Garcia, M.H., 2008, Sediment transport and morphodynamics, chap. 2 of Garcia, M.H., ed., Sedimentation engineeringProcesses, measurements, modeling, and practice: American Society of Civil Engineers manuals and reports on engineering practice, no. 110, p. 21-163.

GeoEngineers, 2008, Levee setback feasibility analysis, Puyallup River watershed, Pierce County, Washington: Redmond, Wash., GeoEngineers, 16 p.

Grant, G.E., 1997, Critical flow constrains flow hydraulics in mobile-bed streams - A new hypothesis: Water Resources Research, v. 33, no. 2, p. 349-358.

Gray, J.R., and Gartner, J.W., 2009, Technological advances in suspended-sediment surrogate monitoring: Water Resources Research, v. 45, no. W00D29, 20 p.

Grove, J.M., 1988, The little ice age: New York, Routledge, Chapman, and Hall, 498 p.

Henderson, F.M., 1966, Open channel flow: New York, Macmillan, 522 p.

Herrera Environmental Consultants, 2010, Summary of sediment trends, lower White River-RM 4.44 to RM 10.60: Seattle, Wash., Herrera Environmental Consultants, $66 \mathrm{p}$.

Hoblitt, R.P., Walder, J.S., Driedger, C.L., Scott, K.M., Pringle, P.T., and Vallance, J.W., 1998, Volcano hazards from Mount Rainier, Washington: U.S. Geological Survey Open-File Report 98-428, 11 p.

Huang, J.V., 2006, Sediment transport capacity study in the setback reach of the Puyallup River: Bureau of Reclamation Report SRH-2009-10, 16 p.

Jarrett, R.D., 1984, Hydraulics of high-gradient streamsProceedings of the American Society of Civil Engineers: Journal of the Hydraulics Division, v. 110, no. 11, p. 15191539.

Juracek, K.E., and Fitzpatrick, F.A., 2009, Geomorphic applications of stream-gage information: River Research and Applications, v. 25, p. 329-347. 
Krimmel, R.M., 2002, Glaciers of the conterminous United States-Glaciers of the western United States, in Williams, R.S., Jr., and Feffigno, J.G., eds., Satellite Image Atlas of Glaciers of the World-North America: U.S. Geological Survey Professional Paper 1386-J, p. J329-J381. (Also available at http://pubs.usgs.gov/pp/p1386j/.)

Lane, E.W., 1955, The importance of fluvial morphology in hydraulic engineering-Proceedings of the American Society of Civil Engineers: Journal of the Hydrologic Division, v. 81, no. 745, p. 1-17.

Limerinos, J.T., 1970, Determination of the Manning coefficient from measured bed roughness in natural channels: U.S. Geological Survey Water-Supply Paper 1898-B, 47 p.

Magirl, C.S., Gartner, J.W., Smart, G.M., and Webb, R.H., 2009, Water velocity and the nature of critical flow in large rapids on the Colorado River, Utah: Water Resources Research, v. 45, no. W05427, p. 17, doi:10.1029/2009WR007731.

Mastin, M.C., Gendaszek, A.S., and Barnas, C.R., 2010, Magnitude and extent of flooding at selected river reaches in western Washington, January 2009: U.S. Geological Survey Scientific Investigations Report 2010-5177, 34 p.

Mills, H.H., 1976, Estimated erosion rates on Mount Rainier, Washington: Geology, v. 4, no. 7, p. 401-406.

Mullineaux, D.R., 1970, Geology of the Renton, Auburn, and Black Diamond Quadrangles, King County, Washington: U.S. Geological Survey Professional Paper 672, 92 p.

National Geodetic Survey, 2003, VERTCON, version 2.1: National Oceanic and Atmospheric Administration website, accessed September 9, 2009, at http://www.ngs.noaa.gov/ PC PROD/VERTCON/.

National Oceanic and Atmospheric Administration, 2010a, Climate of Washington: National Oceanic and Atmospheric Administration website, accessed January 19, 2010, at http://www.wrcc.dri.edu/narratives/WASHINGTON.htm.

National Oceanic and Atmospheric Administration, 2010b, ESA salmon listings: National Oceanic and Atmospheric Administration website, accessed May 7, 2010, at http:// www.nwr.noaa.gov/ESA-Salmon-Listings/upload/ snapshot-7-09.pdf.

National Oceanic and Atmospheric Administration, 2009, Tides and currents-Tide station 9446484, in the Sitcum Waterway of Commencement Bay of the Puget Sound in Tacoma, Washington: National Oceanic and Atmospheric Administration website, accessed November 16, 2009, at http://tidesandcurrents.noaa.gov/geo. shtml?location=9446484.
Nelson, L.M., 1979, Sediment transport by the White River into Mud Mountain Reservoir, Washington, June 1974June 1976: U.S. Geological Survey Water-Resources Investigations 78-133, $26 \mathrm{p}$.

Northwest Hydraulic Consultants Inc., 2009, Floodplain mapping study for White River zone 2 (RM 5.6 to RM 10.6) King County, Washington: Seattle, Wash., Northwest Hydraulic Consultants Inc., 12 p.

Nylen, T.N., 2004, Spatial and Temporal Variations of Glaciers (1913-1994) on Mt. Rainier and the Relation with Climate: Portland, Oreg., Portland State University, M.S. thesis, $111 \mathrm{p}$.

Paola, Chris, Parker, Gary, Seal, Rebecca, Sinha, S.K., Southard, J.B., and Wilcock, P.R., 1992, Downstream fining by selective deposition in a laboratory flume: Science, v. 258, no. 5089, p. 1757-1760.

Parker, Gary, 2008, Transport of gravel and sediment mixtures, chap. 3 of Garcia, M.H., ed., Sedimentation engineeringProcesses, measurements, modeling, and practice: American Society of Civil Engineers manuals and reports on engineering practice, no. 110, p. 165-251.

Piety, L.A., 2009, Sediment transport along gravel bars on the Puyallup River (RM 21.3 to RM 25.2) October 2003 to February 2005, Pierce County, Washington: Bureau of Reclamation Report 86-68330-2009-02, 22 p.

Prych, E.A., 1988, Flood-conveyance capacities and changes in channels of the lower Puyallup, White, and Carbon Rivers in western Washington: U.S. Geological Survey Water-Resources Investigations Report 87-4129, 43 p.

Puget Sound LiDAR Consortium, 2004, Pierce County lowlands: Puget Sound Lidar Consortium website, accessed September 2, 2009, at http://pugetsoundlidar.ess. washington.edu/.

Rantz, S.E., 1982, Measurement and computation of streamflow-Volume 2, Computation of discharge: U.S. Geological Survey Water-Supply Paper 2175, 376 p.

Sambrook Smith, G.H. and Ferguson, R., 1995, The gravelsand transition along river channels: Journal of Sedimentary Research, v. A65, no. 2, p. 423-430.

Scott, K.M., and Vallance, J.W., 1995, Debris flow, debris avalanche, and flood hazards at and downstream from Mount Rainier, Washington: U.S. Geological Survey Hydrologic Investigations Atlas 729, 2 sheets, 9 p. 
Schick, Larry, 2009, The impact of atmospheric rivers on flooding in western Washington, in Conference on Exploring New Hydrologic Warning Frontiers, Vail, Colo., May 2009, Proceedings: National Hydrologic Warning Council: accessed January 2010, at http://www. hydrologicwarning.org/content.aspx?page id $=70 \&$ club $\underline{i d}=617218 \&$ item_id $=7084 \&$ cat $\_i d=4809$.

Sikonia, W.G., 1990, Sediment transport in the lower Puyallup, White, and Carbon Rivers of western Washington: U.S. Geological Survey Water-Resources Investigations Report 89-4112, 84 p.

Simpson, M.R., 2002, Discharge measurements using a broadband acoustic Doppler current profiler: U.S. Geological Survey Open-File Report 01-01, 123 p.

Stover, S.C., and Montgomery, D.R, 2001, Channel change and flooding, Skokomish River, Washington: Journal of Hydrology, v. 243, p. 272-286.

Tetra Tech/Northwest Hydraulic Consultants, 2009, Lower Puyallup River flood protection investigation, withoutproject analysis: Seattle, Wash., Tetra Tech/Northwest Hydraulic Consultants, Project \#135-3540028, about 200 p.

Topcon, 2008, Instruction manual non-prism Total Station GPT-3100W series: West Sacramento, Calif., Topcon, $184 \mathrm{p}$.

U.S. Army Corps of Engineers, 2009, Mud Mountain DamWhite and Puyallup Rivers channel capacity study: Seattle, Wash., U.S. Army Corps of Engineers, 25 p.

U.S. Department of Agriculture, 2010, National Agricultural Imagery Program: U.S. Department of Agriculture website accessed May 12, 2010, at http://www.fsa.usda.gov/FSA/apf oapp?area $=$ home\&subject=prog \& topic $=$ nai.

U.S. Geological Survey, 2010a, StreamStats: U.S. Geological Survey database, accessed June 25, 2010, at http://water. usgs.gov/osw/streamstats/Washington.html.

U.S. Geological Survey, 2010b, Water-Data Report 2009, 12101500 Puyallup River at Puyallup, WA: U.S. Geological Survey Water Data Report, accessed June 29, 2010, at http:// wdr.water.usgs.gov/wy2009/pdfs/12101500.2009.pdf.

Vallance, J.W., and Scott, K.M., 1997, The Osceola mudflow from Mount Rainier-Sedimentology and hazard implications of a huge clay-rich debris flow: Geological Society of America Bulletin, v. 109, no. 2, p. 143-163.

Vries, M. de, 1975, A morphological time-scale for rivers: Delft Hydraulic Laboratory Publication 147, 7 p.
Walder, J.S., and Driedger, C.L., 1995, Frequent outburst floods from South Tahoma Glacier, Mount Rainier, U.S.A.-Relation to debris flows, meteorological origin and implications from subglacial hydrology: Journal of Glaciology, v. 41, no. 137, p. 1-10.

Washington State Department of Ecology, 2010, River and stream water quality monitoring, Puyallup River at Puyallup 10A050: Washington State Department of Ecology website, accessed January 11, 2010, at http://www.ecy.wa.gov/apps/ watersheds/riv/station.asp?sta $=10 \mathrm{~A} 050 \&$ tab $=$ exc.

Washington State Department of Transportation, 2009, Geographic Services, Survey Information System, report of survey mark GP27167-93: Washington State Department of Transportation website, accessed June 22, 2009, at http://www.wsdot.wa.gov/monument/report. cfm?monumentid=4222.

Washington State Reference Network, 2010, A regional cooperative of real-time GPS networks: Washington State Reference Network website, accessed April 28, 2010, at http://www.wsrn.org/.

Wilcock, P.R., and Crowe, J.C., 2003, Surface-based transport model for mixed-size sediment: Journal of Hydraulic Engineering, v. 129, no. 2, p. 120-128.

Wilcock, Peter, Pitlick, John, and Cui, Yantao, 2009, Sediment transport primer: estimating bed-material transport in gravel-bed rivers: U.S. Forest Service General Technical Report RMRS-GTR-226, 78 p.

Wolman, M.G., 1954, A method of sampling coarse river-bed material: Transactions of the American Geophysical Union, v. 35, no. 6, p. 951-956.

Woltemade, C.J., and Potter, K.W., 1994, A watershed modeling analysis of fluvial geomorphologic influences on flood peak attenuation: Water Resources Research, v. 30, no. 6, p. 1933-1942.

Yang, C.T., 1973, Incipient motion and sediment transportProceedings of the American Society of Civil Engineers: Journal of the Hydraulics Division: v. 99, no. HY10, p. 1679-1704.

Yang, C.T., 1984, Unit stream power equation for gravel: Journal of Hydraulic Engineering, v. 110, no. 12, p. 17831797. 


\section{Appendix A. Cross Sections and River Miles in Study Area}

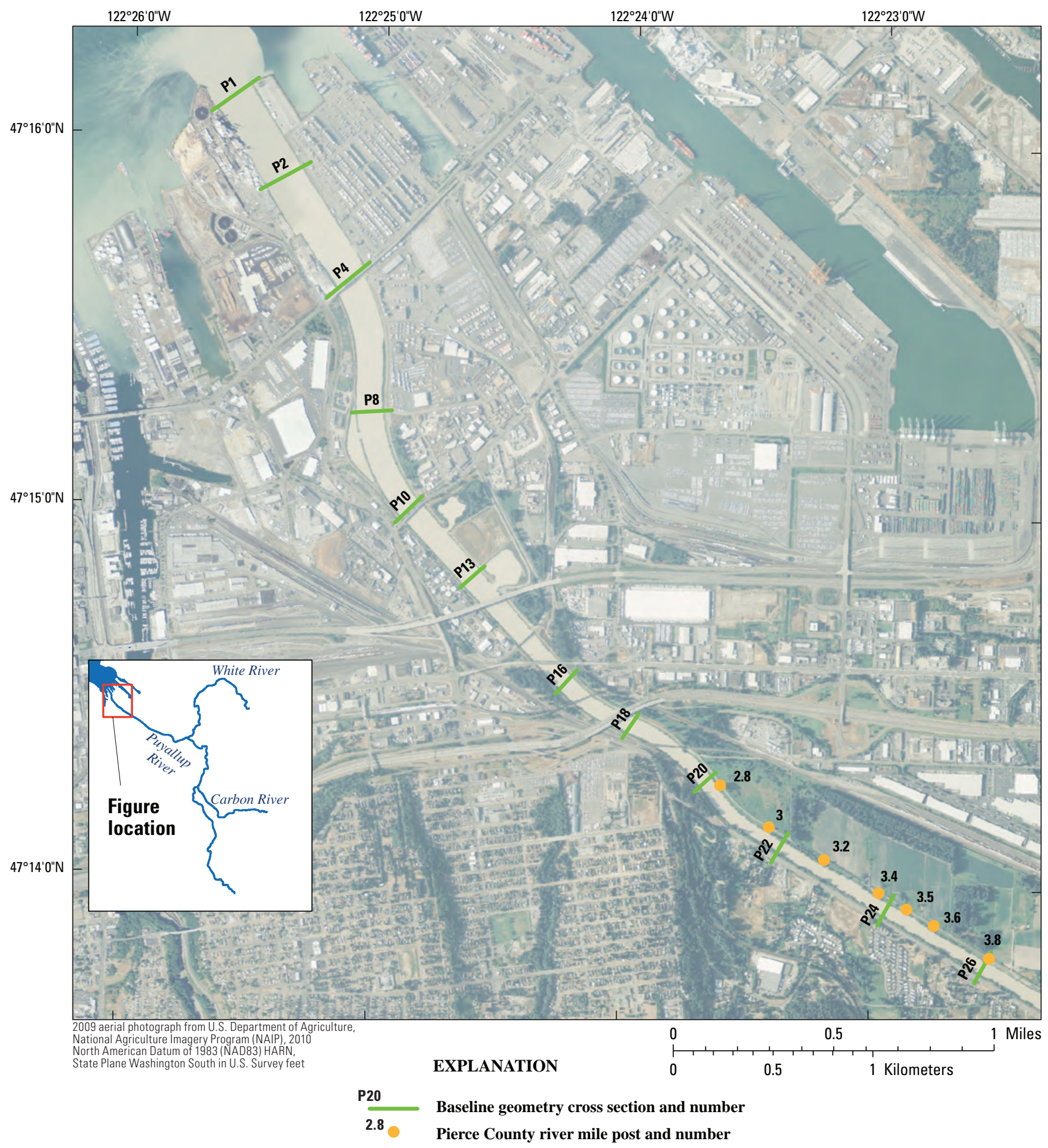

Figure A1. Map showing locations of surveyed baseline geometry cross sections P1-P26 and Pierce County river mile posts for the Puyallup River, western Washington. 


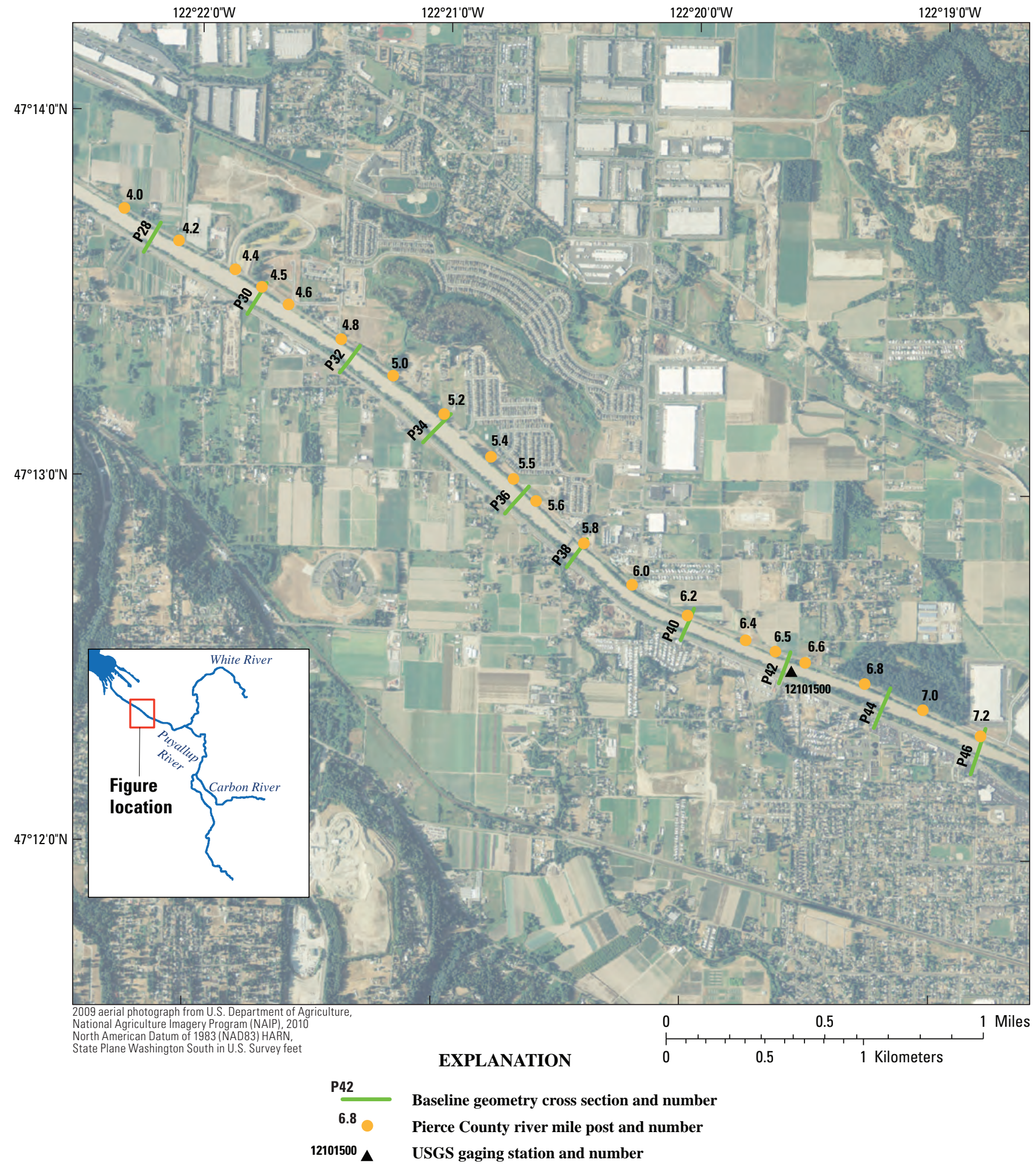

Figure A2. Map showing locations of surveyed baseline geometry cross sections P28-P46 and Pierce County river mile posts for the Puyallup River, western Washington. 


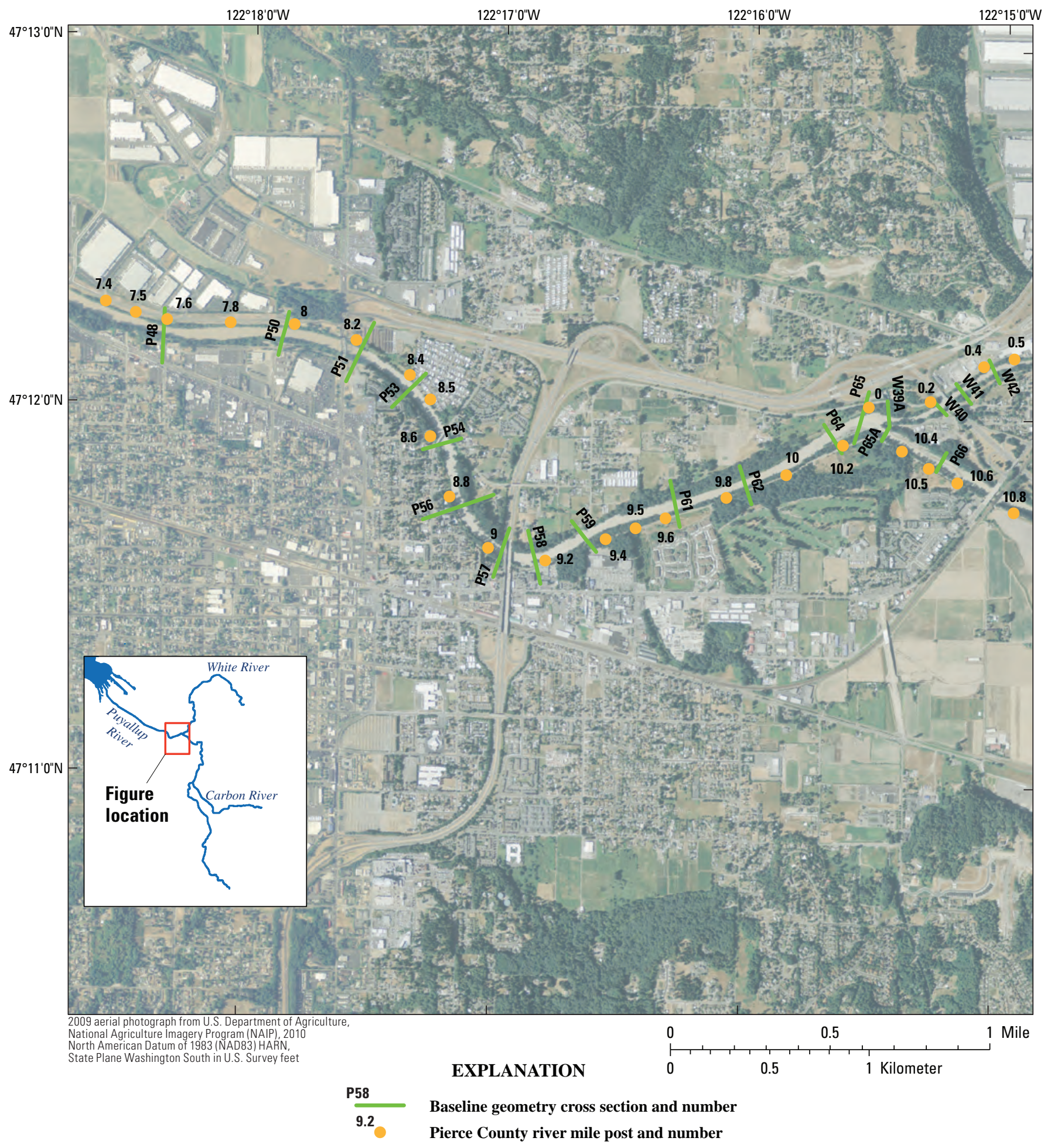

Figure A3. Map showing locations of surveyed baseline geometry cross sections P48-P66 and W39A-W42 and Pierce County river mile posts for the Puyallup and White Rivers, western Washington. 

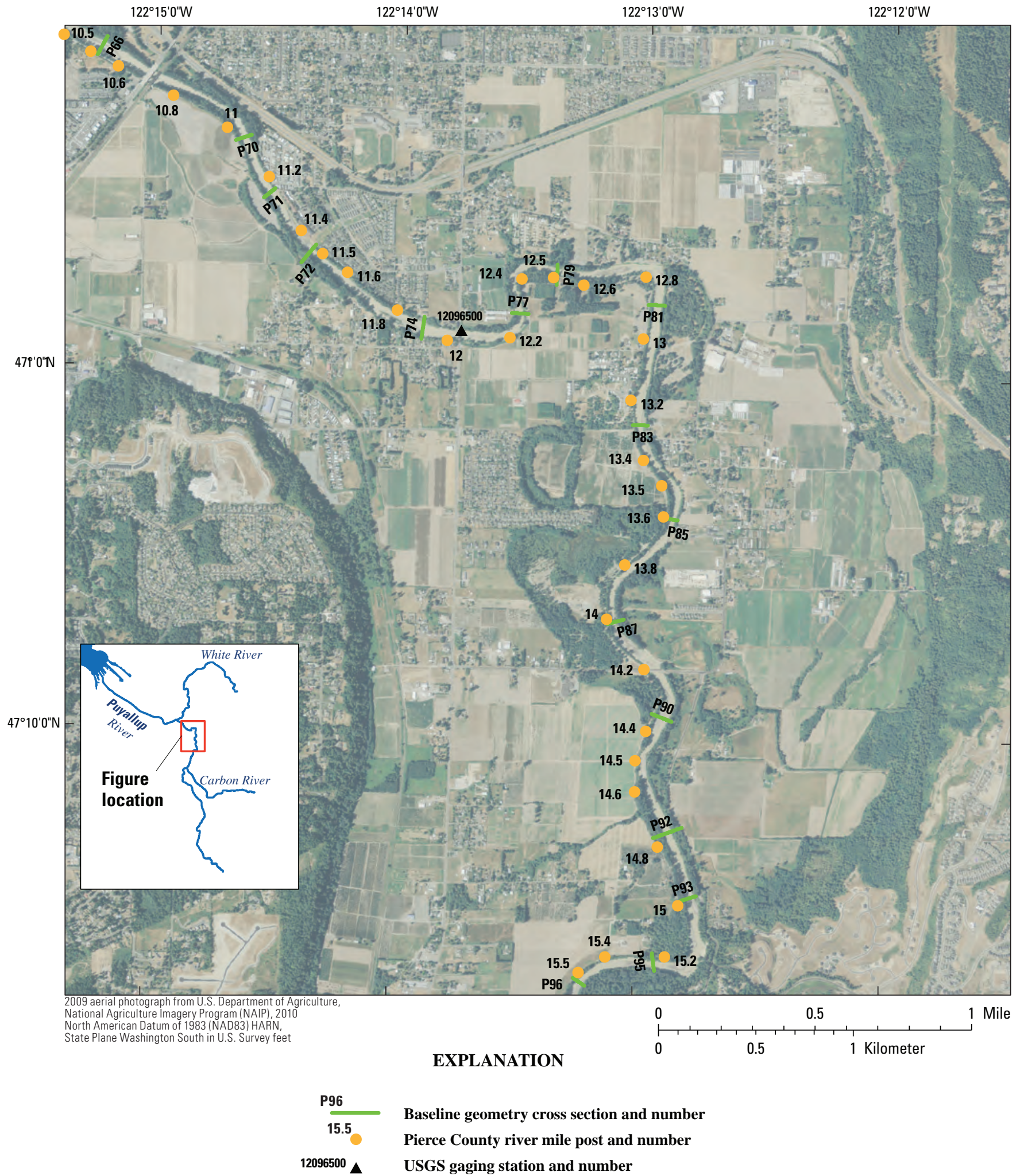

Figure A4. Map showing locations of surveyed baseline geometry cross sections P66-P96 and Pierce County river mile posts for the Puyallup River, western Washington. 


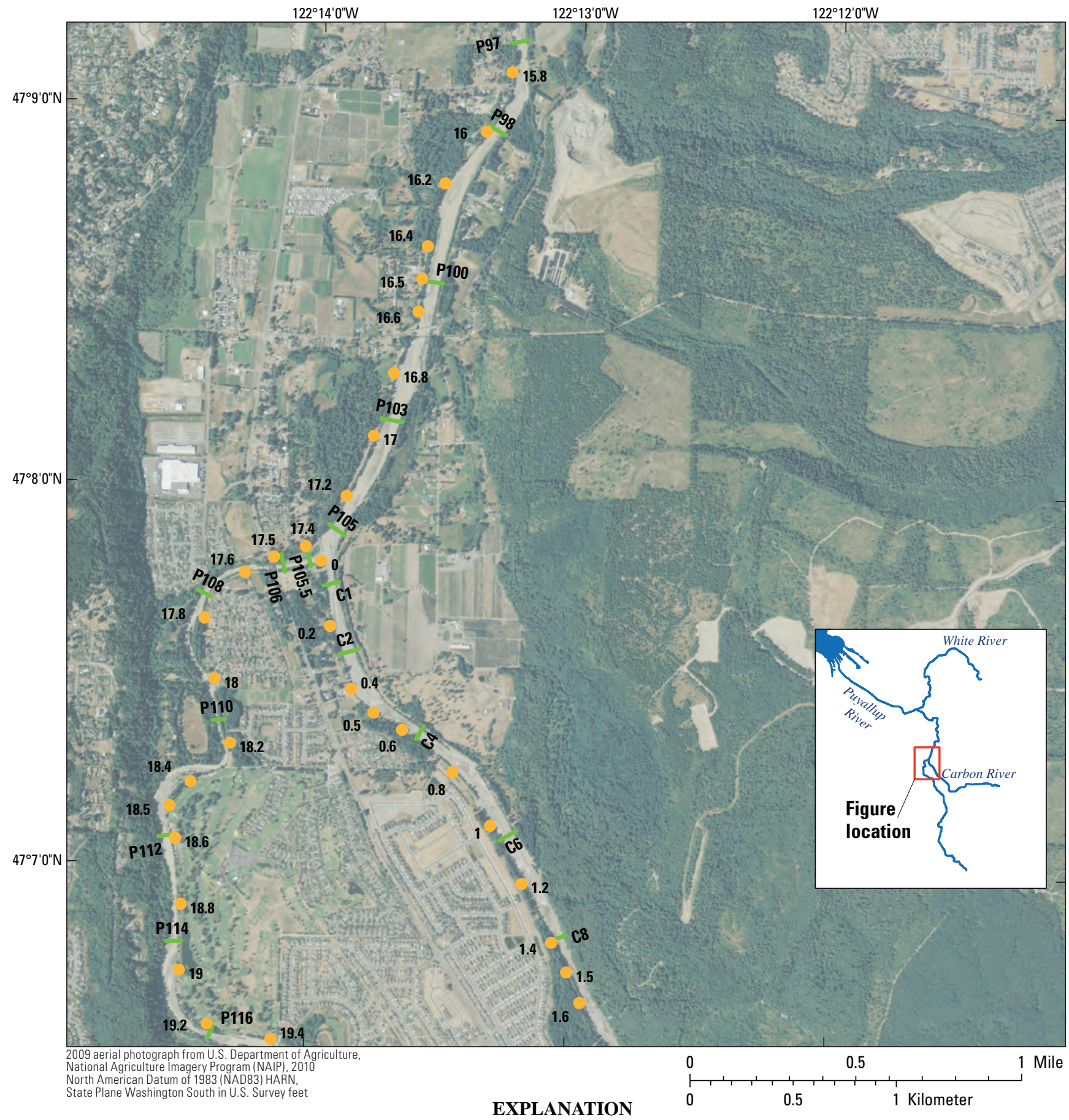

C8

Baseline geometry cross section and number
$1.4 \quad$ Pierce C ounty river mile post and number

Figure A5. Map showing locations of surveyed baseline geometry cross sections P97-P116 and C1-C8 and Pierce County river mile posts for the Puyallup and Carbon Rivers, western Washington. 

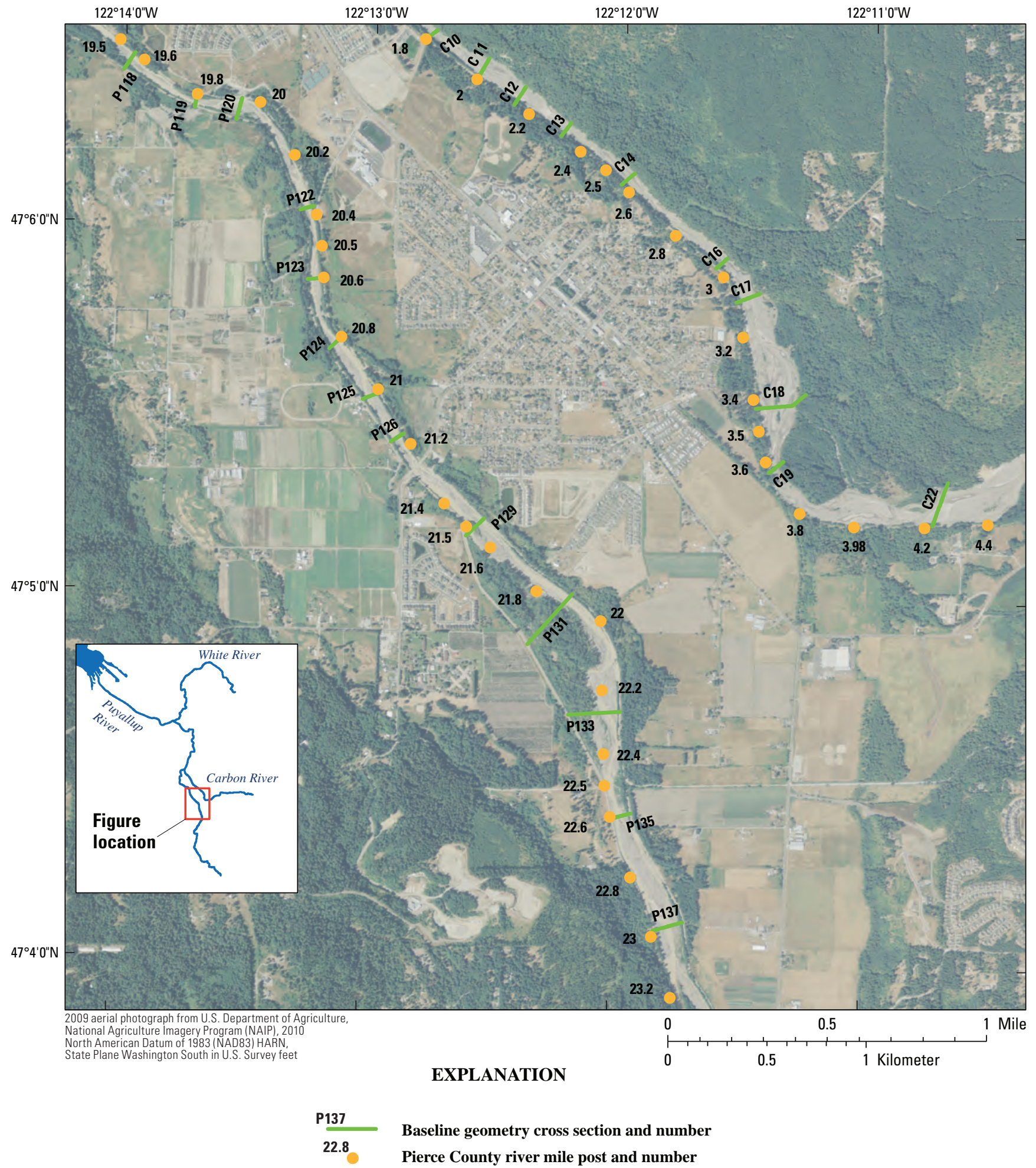

Figure A6. Map showing locations of surveyed baseline geometry cross sections P118-P137 and C10-C22 and Pierce County river mile posts for the Puyallup and Carbon Rivers, western Washington. 

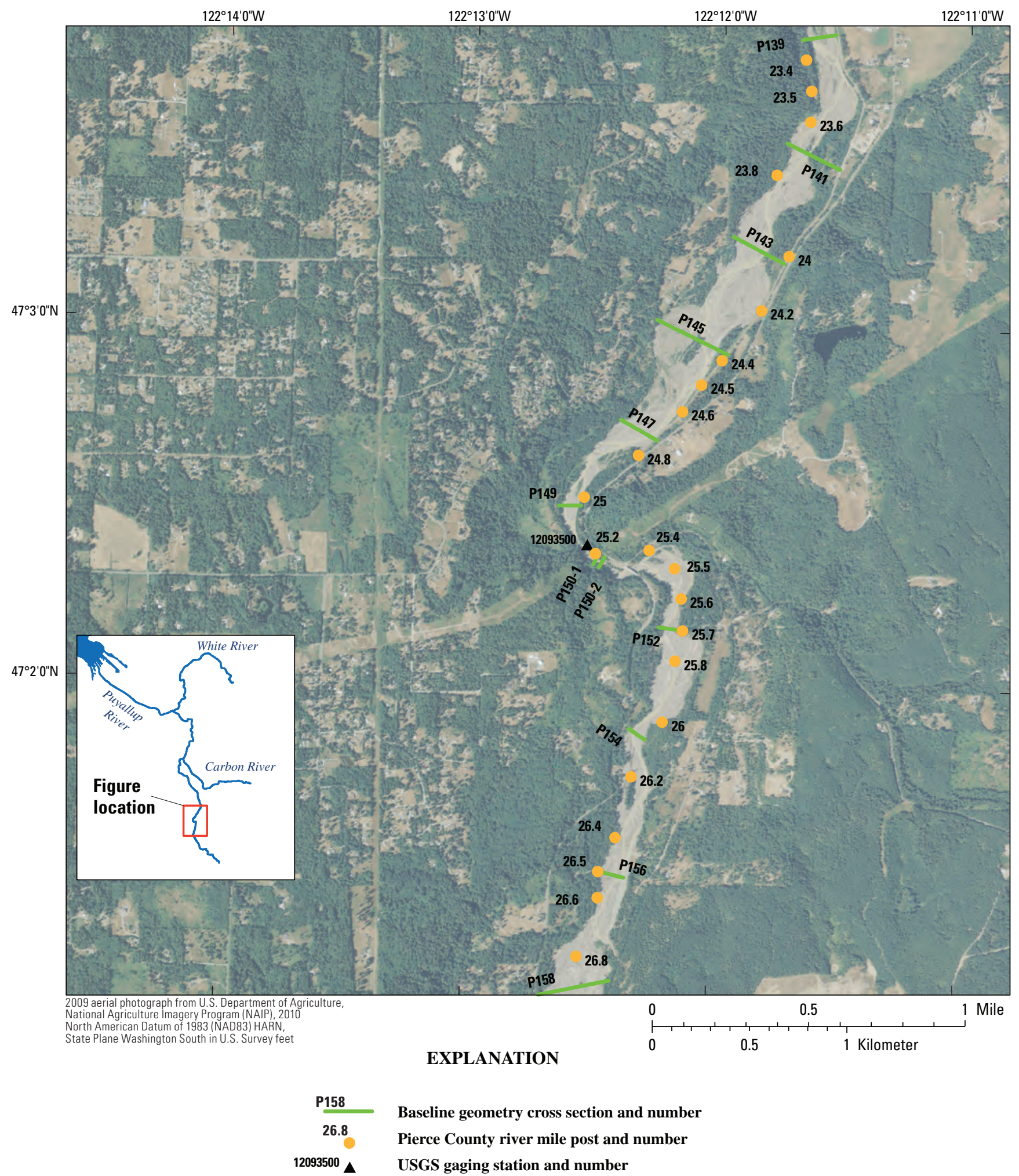

Figure A7. Map showing locations of surveyed baseline geometry cross sections P139-P158 and Pierce County river mile posts for the Puyallup River, western Washington. 


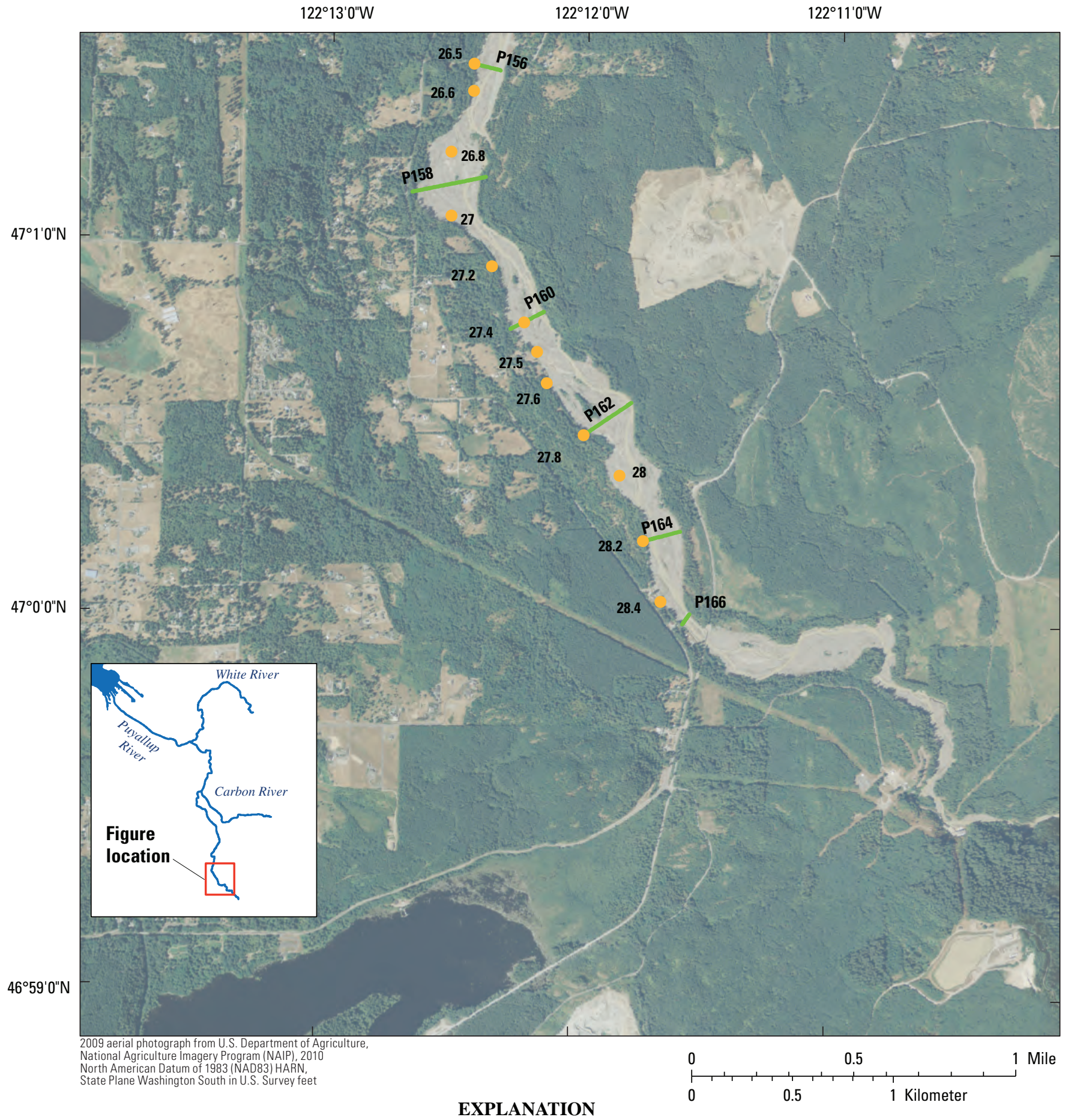

Figure A8. Map showing locations of surveyed baseline geometry cross sections P156-P166 and Pierce County river mile posts for the Puyallup River, western Washington. 


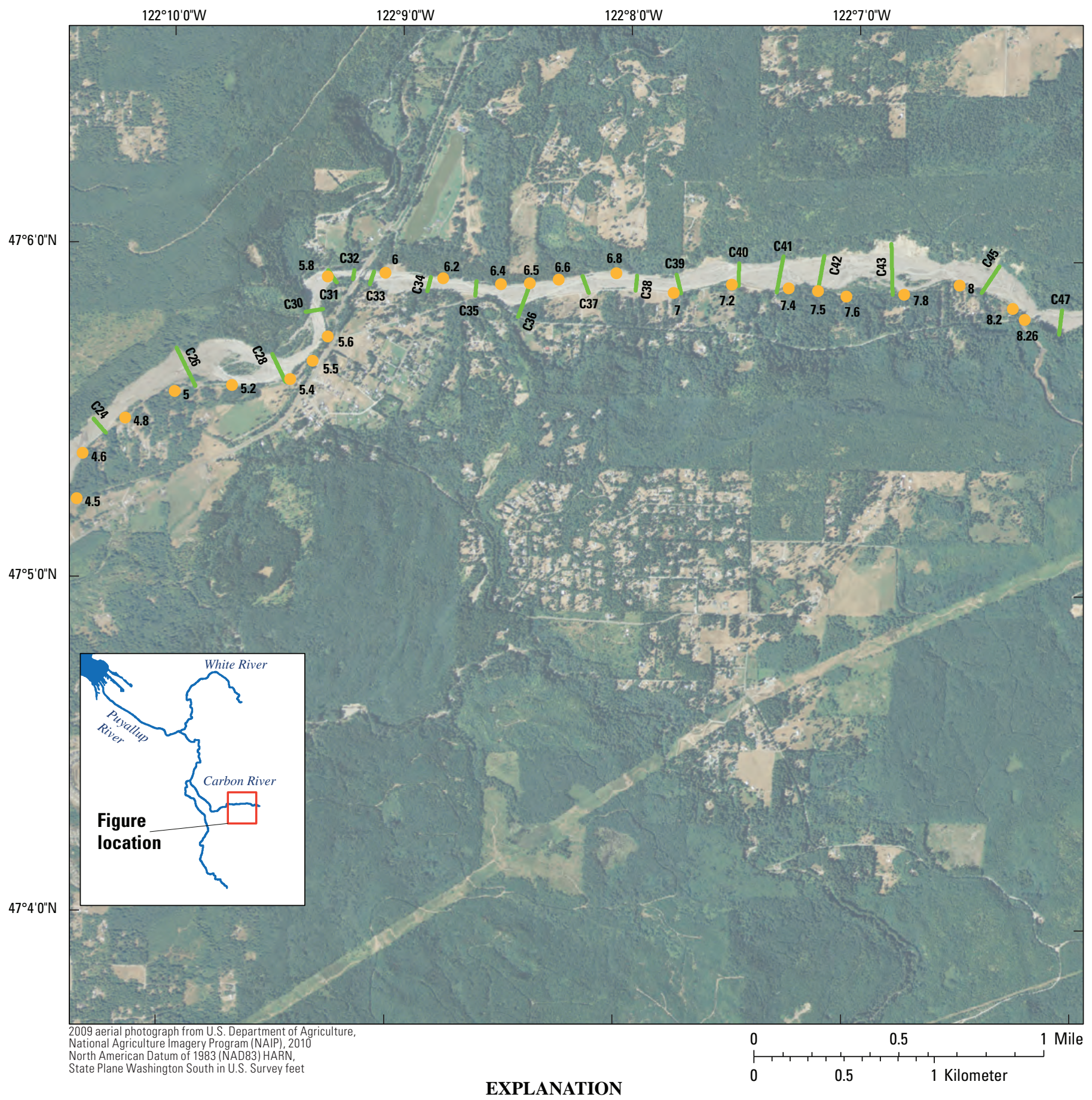

C24

4.8 Baseline geometry cross section and number

Pierce County river mile post and number

Figure A9. Map showing locations of surveyed baseline geometry cross sections C24-C47 and Pierce County river mile posts for the Carbon River, western Washington. 


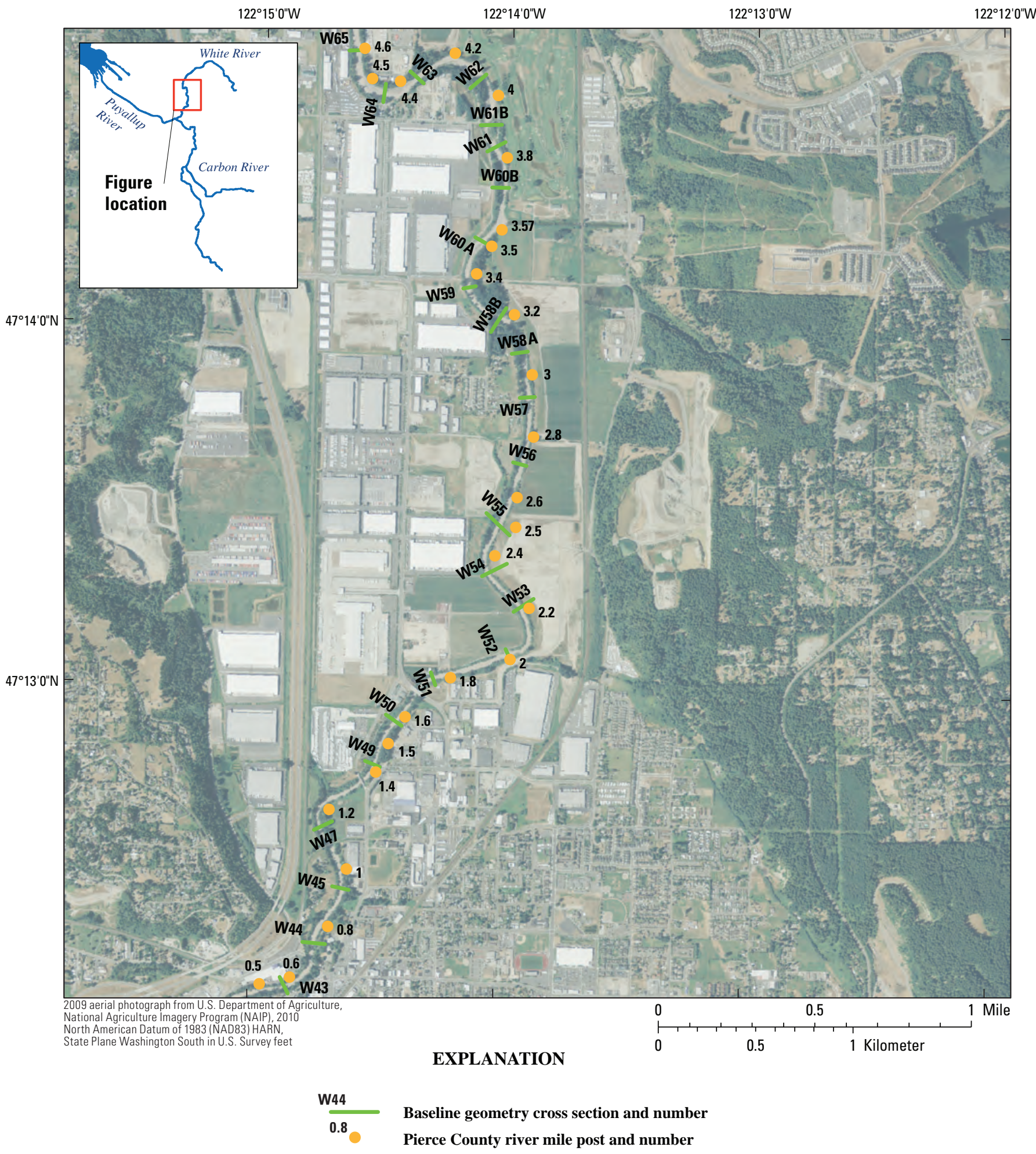

Figure A10. Map showing locations of surveyed baseline geometry cross sections W43-W65 and Pierce County river mile posts for the White River, western Washington. 


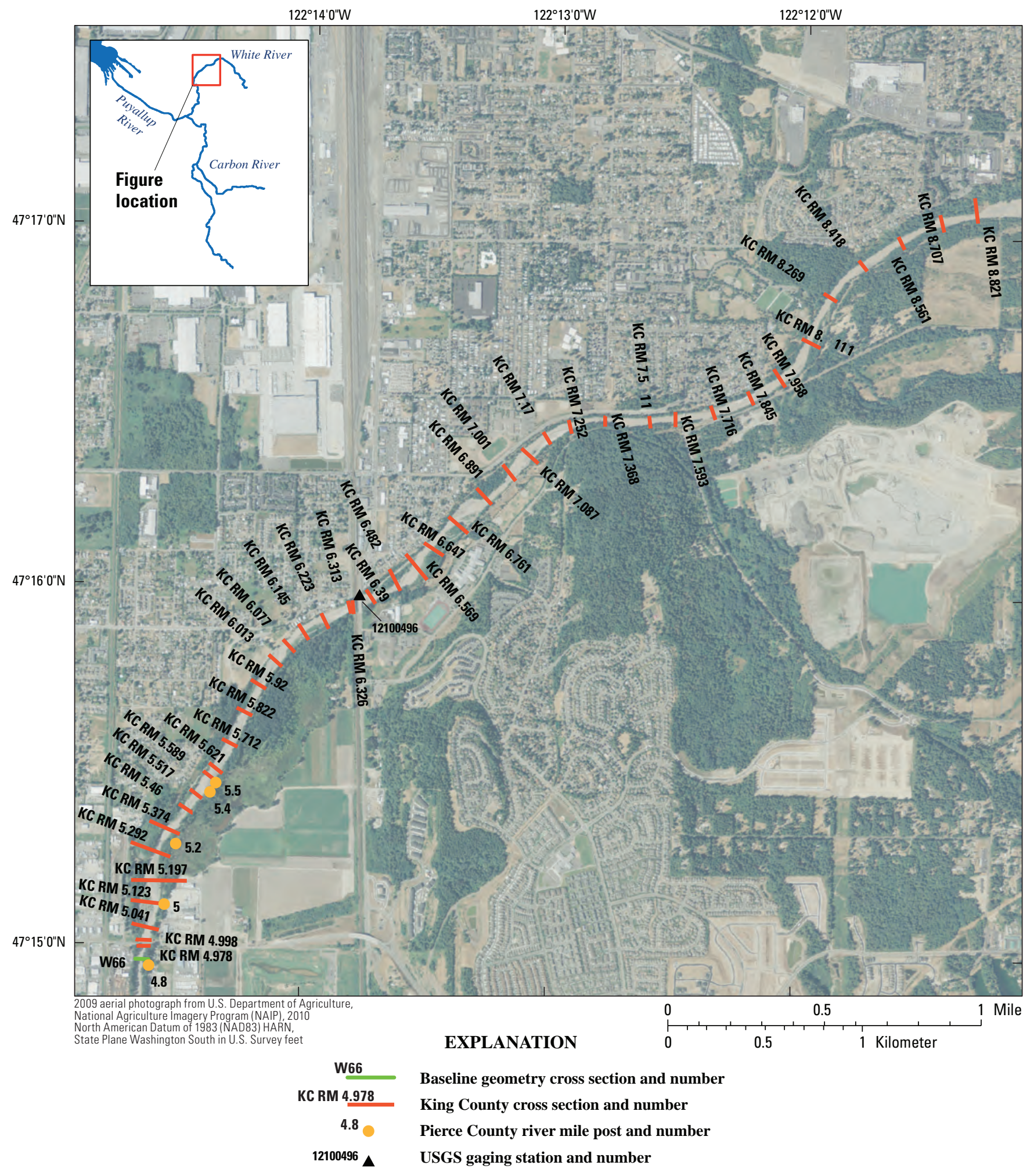

Figure A11. Map showing locations of surveyed baseline geometry cross section W66, King County cross sections KC RM 4.978-KC RM 8.821, and Pierce County river mile posts for the White River, western Washington. 


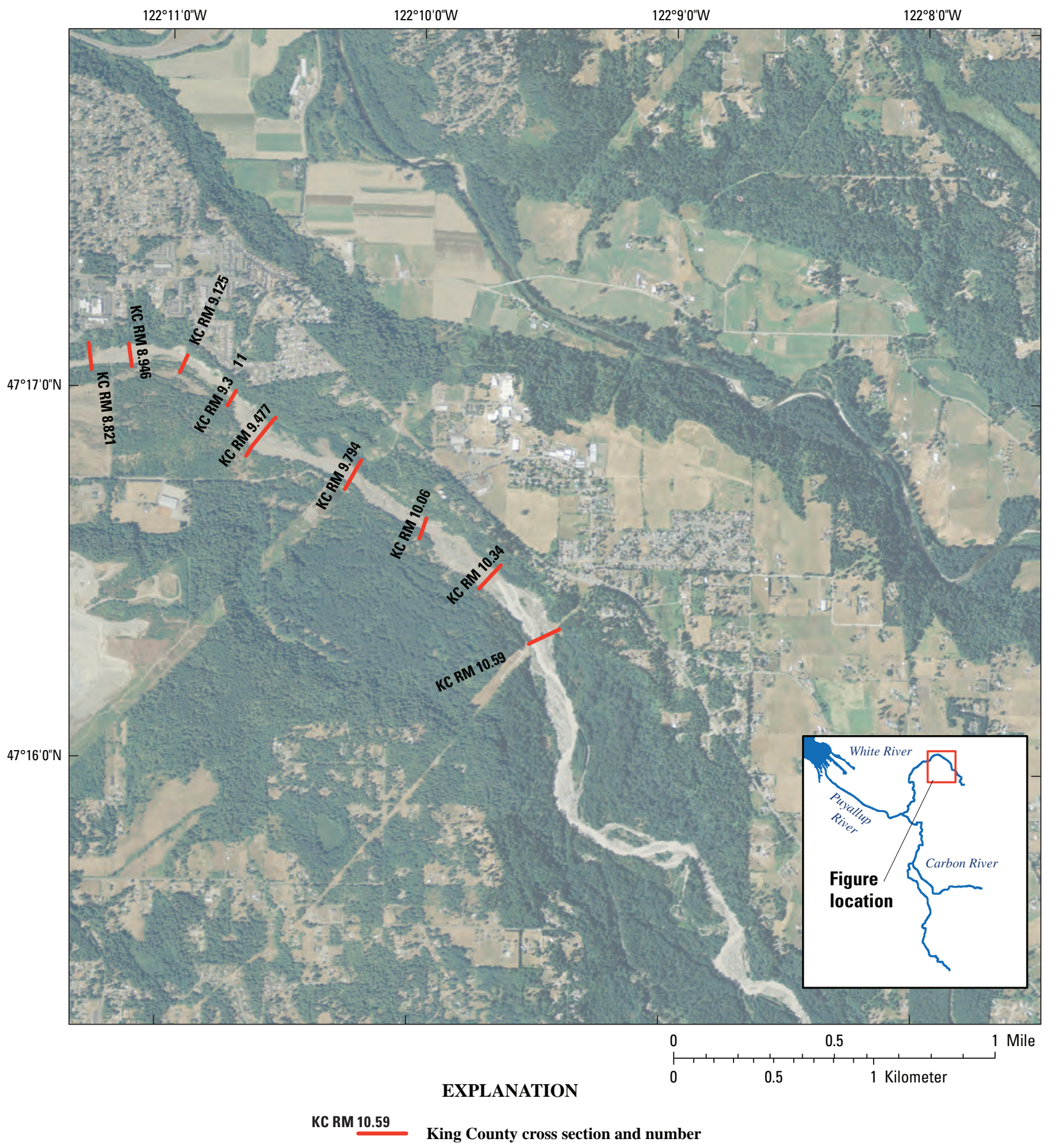

Figure A12. Map showing locations of King County cross sections KC RM 8.821-KC RM 10.59 for the White River, western Washington. 


\section{Appendix B. Temporal Trends At Selected Streamflow-Gaging Stations}

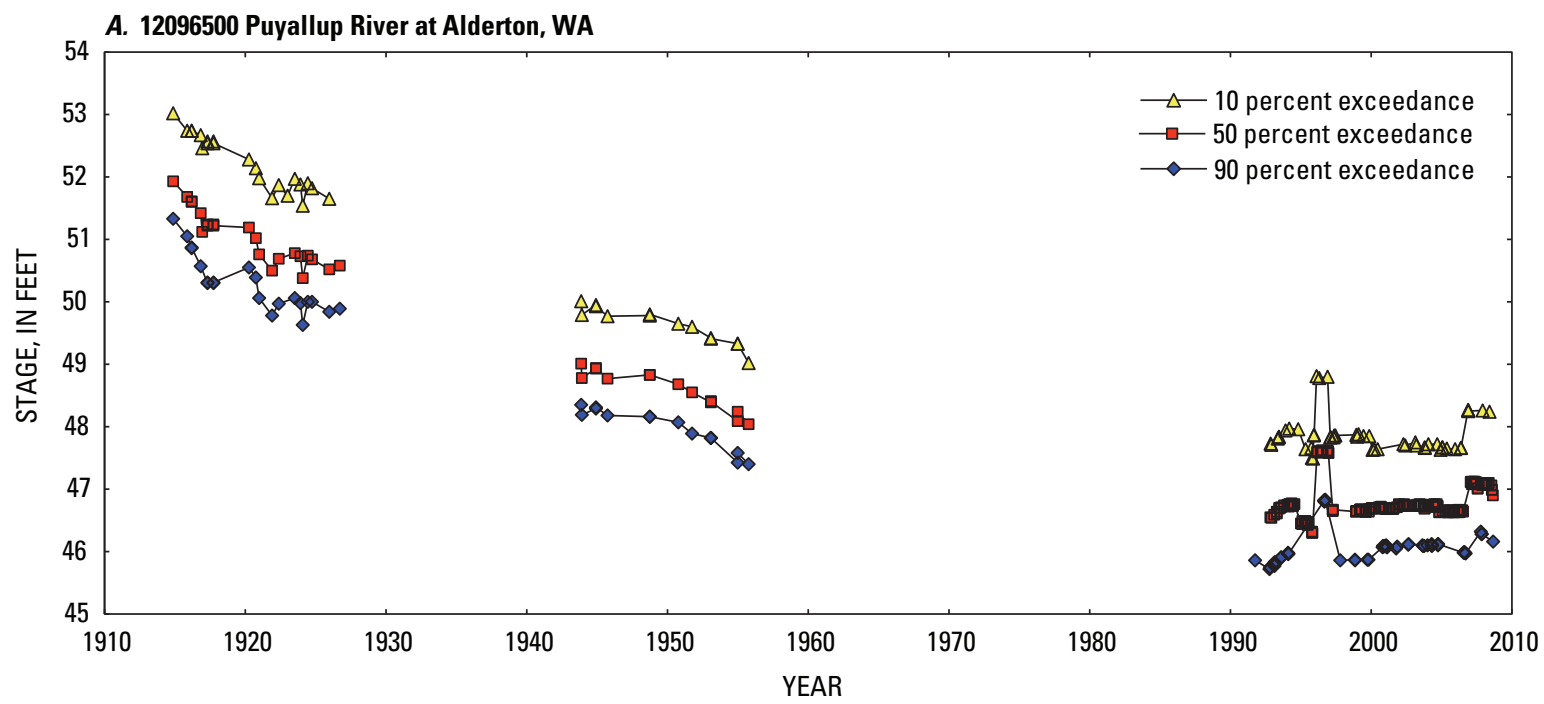

B. 12093500 Puyallup River near Orting, WA
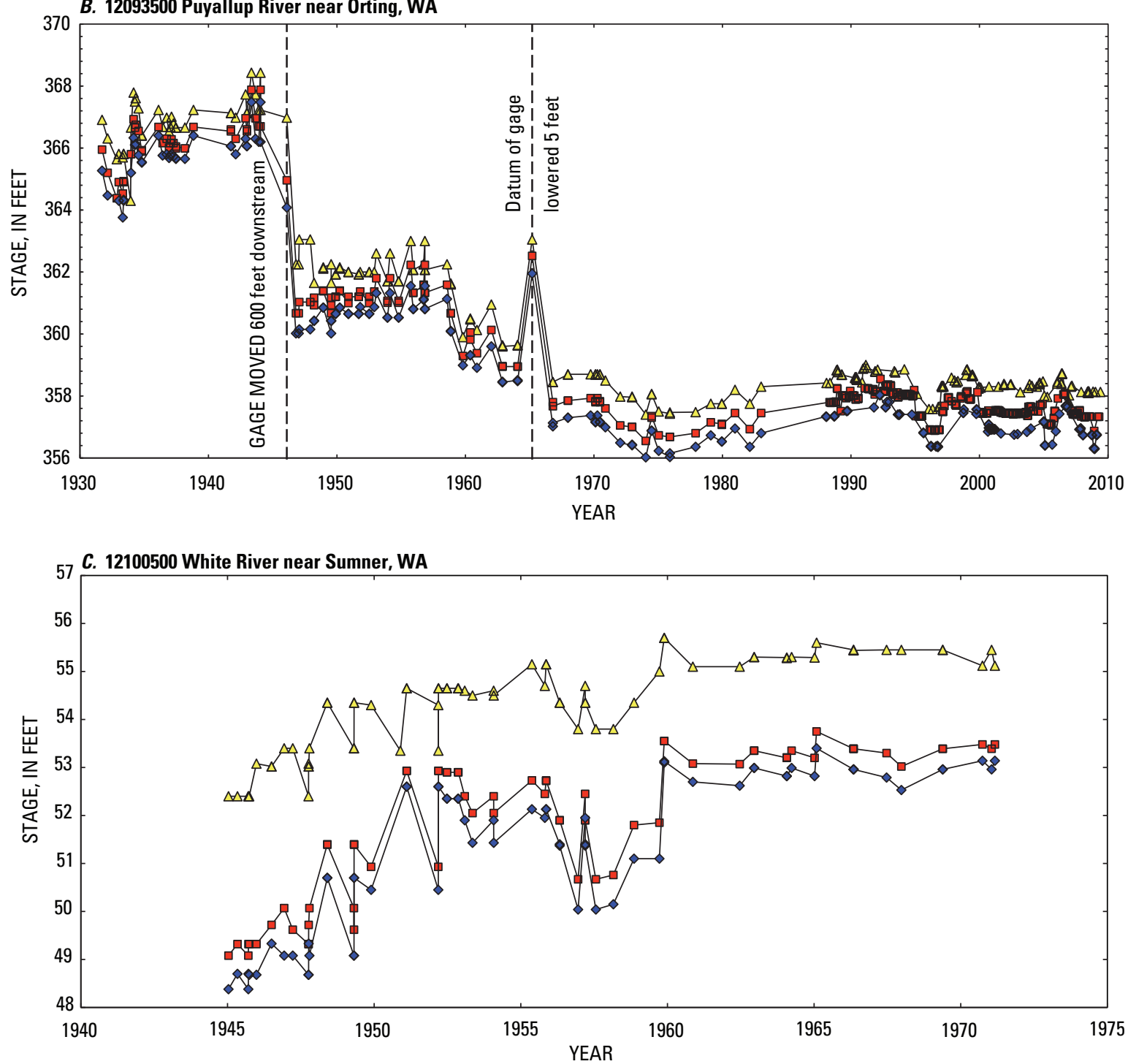

Figure B1. Graphs showing stage for period of record at 10, 50, and 90 percent exceedance for selected gaging stations, western Washington. 

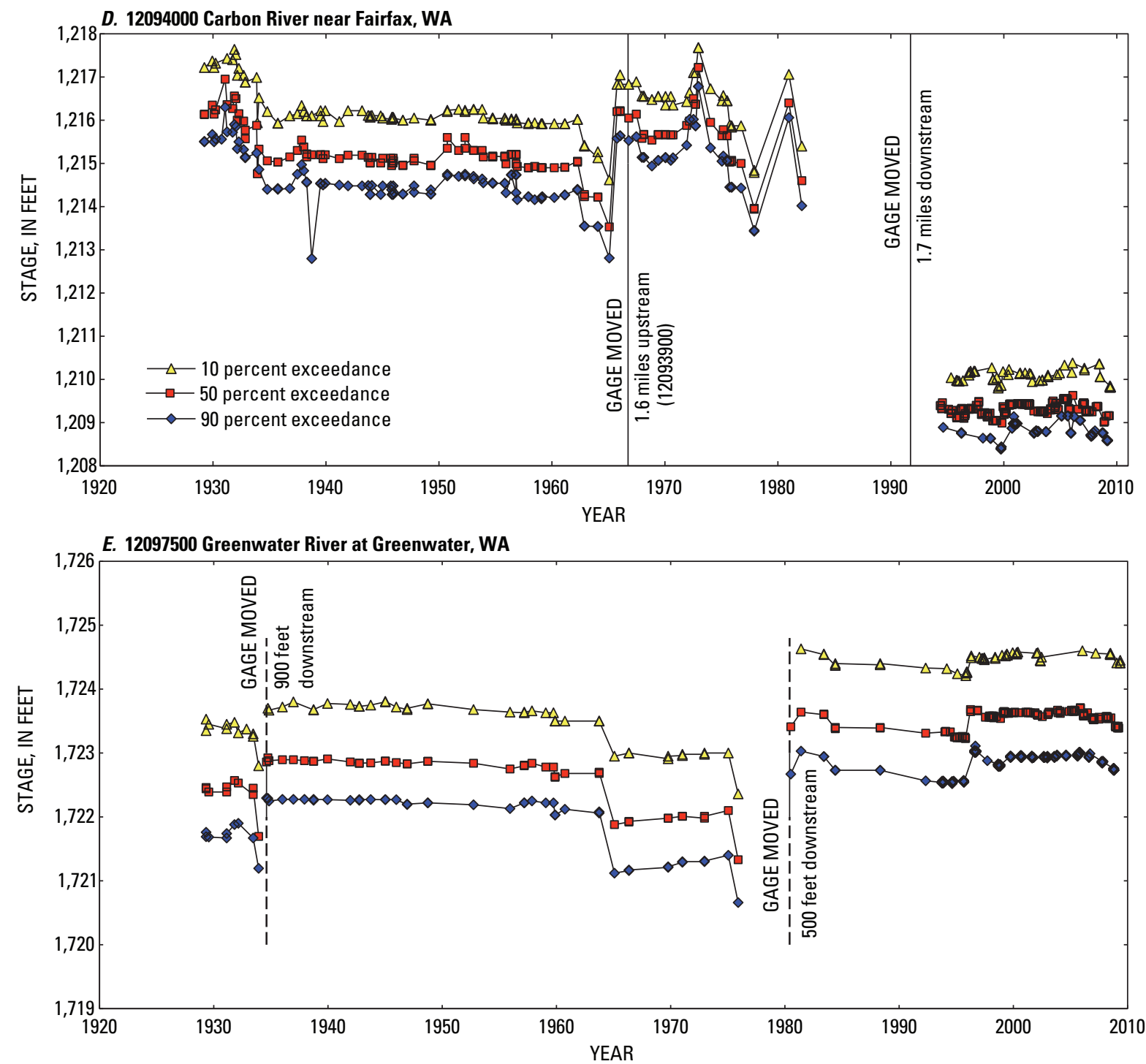

F. 12095000 South Prairie Creek at South Prairie, WA

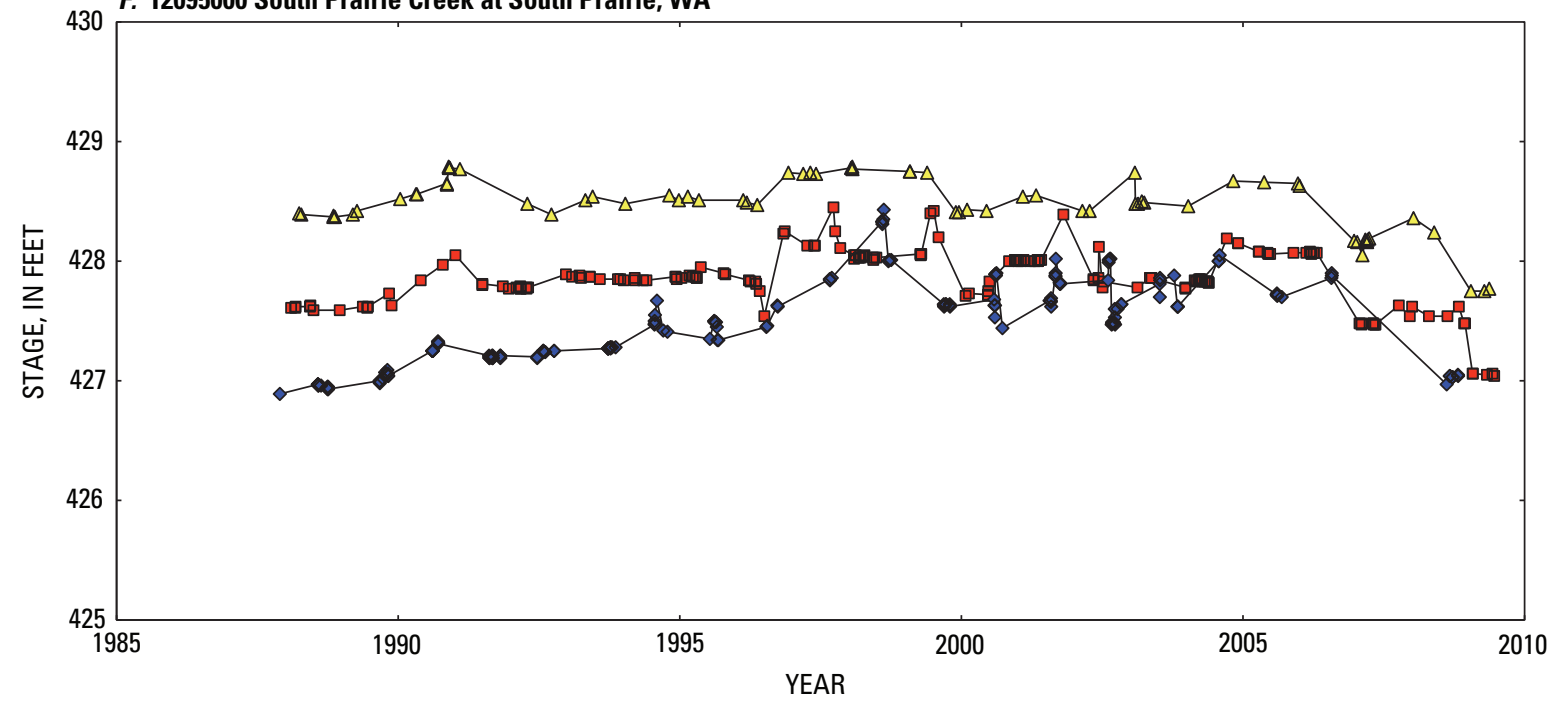

Figure B1.-Continued 


\section{Appendix C. Channel-Conveyance Capacity}

Table C1. Channel-conveyance capacity, Puyallup, White and Carbon Rivers, western Washington, 2009.

[Locations of cross sections are shown in figures A1-A12. Elevation is referenced to the North American Vertical Datum of 1988 (NAVD 88 ).

Abbreviations: $\mathrm{ft}$, foot; $\mathrm{ft}^{3} / \mathrm{s}$, cubic foot per second; >, greater than; <, less than]

\begin{tabular}{|c|c|c|c|c|c|c|c|}
\hline \multirow{3}{*}{ Cross section } & \multirow{3}{*}{$\begin{array}{l}\text { River } \\
\text { mile }\end{array}$} & \multirow{2}{*}{\multicolumn{2}{|c|}{$\begin{array}{c}\text { Top of bank elevation } \\
\text { (ft) }\end{array}$}} & \multicolumn{4}{|c|}{ Channel-conveyance capacity $\left(\mathrm{ft}^{3} / \mathrm{s}\right)$} \\
\hline & & & & \multicolumn{2}{|c|}{ Top of bank } & \multicolumn{2}{|c|}{ Below top of bank ( $3 \mathrm{ft}$ ) } \\
\hline & & Left bank & Right bank & Left bank & Right bank & Left bank & Right bank \\
\hline \multicolumn{8}{|c|}{ Puyallup River } \\
\hline P1 & 0.0 & 13.64 & 7.97 & $>50,000$ & N/A & $>50,000$ & N/A \\
\hline P2 & .3 & 15.99 & 15.14 & $>50,000$ & $>50,000$ & $>50,000$ & $>50,000$ \\
\hline P4 & .7 & 14.63 & 15.92 & $>50,000$ & $>50,000$ & $>50,000$ & $>50,000$ \\
\hline P8 & 1.1 & 17.85 & 17.79 & $>50,000$ & $>50,000$ & $>50,000$ & $>50,000$ \\
\hline $\mathrm{P} 10$ & 1.5 & 18.69 & 18.84 & $>50,000$ & $>50,000$ & $>50,000$ & $>50,000$ \\
\hline P13 & 1.8 & 18.13 & 18.97 & $>50,000$ & $>50,000$ & $>50,000$ & $>50,000$ \\
\hline P16 & 2.2 & 21.17 & 21.52 & $>50,000$ & $>50,000$ & $>50,000$ & $>50,000$ \\
\hline P18 & 2.5 & 22.15 & 22.26 & $>50,000$ & $>50,000$ & $>50,000$ & $>50,000$ \\
\hline P20 & 2.7 & 23.53 & 23.63 & $>50,000$ & $>50,000$ & $>50,000$ & $>50,000$ \\
\hline P22 & 3.1 & 22.64 & 22.11 & $>50,000$ & $>50,000$ & 43,200 & 41,000 \\
\hline P24 & 3.4 & 24.45 & 25.09 & $>50,000$ & $>50,000$ & 44,800 & 47,500 \\
\hline P26 & 3.8 & 26.03 & 25.49 & $>50,000$ & $>50,000$ & 46,100 & 43,900 \\
\hline P28 & 4.1 & 27.14 & 27.11 & $>50,000$ & $>50,000$ & 44,400 & 44,200 \\
\hline P30 & 4.5 & 28.21 & 29.40 & 48,500 & $>50,000$ & 39,100 & 43,500 \\
\hline P32 & 4.9 & 31.83 & 30.67 & $>50,000$ & 48,500 & 44,100 & 40,000 \\
\hline P34 & 5.2 & 31.27 & 31.63 & 48,000 & 48,300 & 38,100 & 39,300 \\
\hline P36 & 5.5 & 32.63 & 32.85 & 48,200 & 48,400 & 39,100 & 39,900 \\
\hline P38 & 5.8 & 37.20 & 34.21 & $>50,000$ & 48,400 & 48,400 & 40,500 \\
\hline P40 & 6.2 & 34.44 & 35.49 & 41,700 & 44,900 & 34,200 & 37,200 \\
\hline P42 & 6.6 & 35.02 & 37.98 & 39,500 & 47,000 & 31,600 & 39,400 \\
\hline P44 & 6.9 & 37.06 & 37.05 & 39,000 & 39,000 & 31,900 & 31,900 \\
\hline P46 & 7.2 & 44.65 & 39.16 & $>50,000$ & 41,000 & 48,200 & 34,000 \\
\hline P48 & 7.6 & 42.95 & 40.14 & 49,500 & 41,000 & 40,500 & 33,900 \\
\hline P50 & 8.0 & 42.69 & 40.49 & 43,500 & 37,800 & 35,700 & 29,800 \\
\hline P51 & 8.2 & 48.87 & 51.59 & $>50,000$ & $>50,000$ & $>50,000$ & $>50,000$ \\
\hline P53 & 8.4 & 39.23 & 45.41 & 31,700 & 49,900 & 24,100 & 40,000 \\
\hline P54 & 8.6 & 48.07 & 52.27 & $>50,000$ & $>50,000$ & 45,200 & $>50,000$ \\
\hline P56 & 8.8 & 52.66 & 51.02 & $>50,000$ & $>50,000$ & $>50,000$ & 48,800 \\
\hline P57 & 9.0 & 52.17 & 59.37 & $>50,000$ & $>50,000$ & $>50,000$ & $>50,000$ \\
\hline P58 & 9.1 & 52.54 & 49.35 & $>50,000$ & $>50,000$ & $>50,000$ & 40,900 \\
\hline P59 & 9.3 & 42.13 & 51.61 & 26,000 & $>50,000$ & 20,600 & 46,000 \\
\hline P61 & 9.6 & 43.47 & 55.70 & 22,600 & $>50,000$ & 20,000 & $>50,000$ \\
\hline P62 & 9.8 & 46.92 & 47.67 & 26,100 & 28,900 & 20,200 & 20,800 \\
\hline P64 & 10.1 & 54.37 & 50.01 & 44,400 & 29,900 & 34,800 & 20,800 \\
\hline P65 & 10.3 & 51.22 & 64.62 & 32,700 & $>50,000$ & 22,500 & $>50,000$ \\
\hline P65A & 10.3 & 48.86 & 49.12 & 14,000 & 14,200 & 12,000 & 12,000 \\
\hline P66 & 10.5 & 49.62 & 50.23 & 14,000 & 15,600 & 12,000 & 12,100 \\
\hline P70 & 11.1 & 53.88 & 54.65 & 19,400 & 21,300 & 13,600 & 14,600 \\
\hline P71 & 11.3 & 56.12 & 56.69 & 20,200 & 21,600 & 14,400 & 15,500 \\
\hline P72 & 11.5 & 68.11 & 59.73 & $>36,000$ & 21,800 & $>36,000$ & 18,300 \\
\hline P74 & 12.0 & 69.69 & 67.03 & $>36,000$ & 32,500 & 31,400 & 23,500 \\
\hline P77 & 12.3 & 68.01 & 74.95 & 28,900 & $>36,000$ & 22,300 & $>36,000$ \\
\hline P79 & 12.6 & 73.25 & 69.92 & 33,400 & 26,300 & 26,700 & 20,200 \\
\hline P81 & 13.0 & 73.87 & 72.90 & 24,100 & 22,200 & 19,000 & 17,200 \\
\hline P83 & 13.4 & 78.08 & 77.38 & 20,900 & 19,800 & 15,900 & 14,700 \\
\hline P85 & 13.8 & 81.06 & 85.36 & 16,900 & 25,500 & 12,500 & 19,300 \\
\hline P87 & 14.2 & 87.31 & 89.02 & 18,500 & 21,800 & 13,900 & 16,400 \\
\hline P90 & 14.5 & 93.00 & 90.50 & 26,700 & 21,000 & 20,100 & 16,100 \\
\hline
\end{tabular}


Table C1. Channel-conveyance capacity, Puyallup, White and Carbon Rivers, western Washington, 2009.-Continued

[Locations of cross sections are shown in figures A1-A12. Elevation is referenced to the North American Vertical Datum of 1988 (NAVD 88 ). Abbreviations: $\mathrm{ft}$, foot; $\mathrm{ft}^{3} / \mathrm{s}$, cubic foot per second; >, greater than; <, less than]

\begin{tabular}{|c|c|c|c|c|c|c|c|}
\hline \multirow{3}{*}{ Cross section } & \multirow{3}{*}{$\begin{array}{l}\text { River } \\
\text { mile }\end{array}$} & \multirow{2}{*}{\multicolumn{2}{|c|}{$\begin{array}{c}\text { Top of bank elevation } \\
\text { (ft) }\end{array}$}} & \multicolumn{4}{|c|}{ Channel-conveyance capacity $\left(\mathrm{ft}^{3} / \mathrm{s}\right)$} \\
\hline & & & & \multicolumn{2}{|c|}{ Top of bank } & \multicolumn{2}{|c|}{ Below top of bank (3 ft) } \\
\hline & & Left bank & Right bank & Left bank & Right bank & Left bank & Right bank \\
\hline \multicolumn{8}{|c|}{ Puyallup River-Continued } \\
\hline P92 & 14.9 & 97.53 & 93.91 & 34,300 & 25,000 & 26,500 & 18,900 \\
\hline P93 & 15.2 & 93.11 & 96.82 & 20,200 & 29,300 & 14,900 & 21,600 \\
\hline P95 & 15.5 & 107.14 & 96.76 & $>36,000$ & 20,500 & $>36,000$ & 15,400 \\
\hline P96 & 15.7 & 104.28 & 102.18 & 25,600 & 20,600 & 19,300 & 15,100 \\
\hline P97 & 15.9 & 101.46 & 101.63 & 16,300 & 16,600 & 11,000 & 11,300 \\
\hline P98 & 16.2 & 107.21 & 106.74 & 24,300 & 23,300 & 18,200 & 17,400 \\
\hline P100 & 16.7 & 113.52 & 112.73 & 26,300 & 24,100 & 18,800 & 17,400 \\
\hline P103 & 17.1 & 120.78 & 121.33 & $>36,000$ & $>36,000$ & 31,200 & 33,200 \\
\hline P105 & 17.5 & 123.26 & 126.77 & 27,500 & $>36,000$ & 16,700 & 29,500 \\
\hline P105.5 & 17.6 & 127.28 & 123.49 & 14,500 & 9,500 & 9,900 & 5,500 \\
\hline P106 & 17.7 & 128.86 & 134.78 & 14,500 & $>17,200$ & 9,500 & $>17,200$ \\
\hline P108 & 18.0 & 131.03 & 130.45 & 14,000 & 13,300 & 9,700 & 9,300 \\
\hline P110 & 18.4 & 133.84 & 134.86 & 9,100 & 10,200 & 7,100 & 8,400 \\
\hline P112 & 18.9 & 145.67 & 142.42 & $>17,200$ & 12,100 & 12,600 & 7,900 \\
\hline P114 & 19.2 & 153.30 & 148.43 & $>17,200$ & $>17,200$ & $>17,200$ & 10,500 \\
\hline P116 & 19.5 & 151.79 & 153.38 & 8,800 & 12,100 & 4,300 & 7,100 \\
\hline P118 & 19.9 & 161.31 & 160.02 & 11,700 & 8,900 & 7,100 & 5,300 \\
\hline P119 & 20.1 & 163.98 & 165.15 & 7,400 & 9,300 & 3,400 & 5,000 \\
\hline P120 & 20.3 & 170.34 & 169.55 & 13,400 & 11,500 & 6,900 & 6,400 \\
\hline P122 & 20.7 & 179.44 & 177.31 & 13,700 & 8,000 & 7,600 & 5,200 \\
\hline P123 & 20.9 & 183.70 & 182.87 & 13,700 & 11,700 & 7,800 & 6,600 \\
\hline P124 & 21.1 & 187.71 & 188.89 & 13,400 & 16,600 & 6,300 & 8,900 \\
\hline P125 & 21.3 & 194.04 & 194.61 & 15,400 & 16,800 & 8,100 & 9,700 \\
\hline P126 & 21.5 & 197.79 & 197.61 & 12,700 & 12,300 & 5,900 & 5,500 \\
\hline P129 & 21.8 & 211.40 & 211.83 & $>17,200$ & $>17,200$ & $>17,200$ & $>17,200$ \\
\hline P131 & 22.2 & 220.36 & 220.21 & $>17,200$ & 16,500 & 6,600 & 7,800 \\
\hline P133 & 22.6 & 234.66 & 236.54 & $>17,200$ & $>17,200$ & 4,900 & $>17,200$ \\
\hline P135 & 22.9 & 251.39 & 246.71 & $>17,200$ & 15,000 & $>17,200$ & 9,700 \\
\hline P137 & 23.3 & 265.43 & 265.42 & $>17,200$ & $>17,200$ & $>17,200$ & $>17,200$ \\
\hline P139 & 23.7 & 277.39 & 278.15 & $>17,200$ & $>17,200$ & 16,200 & 16,600 \\
\hline P141 & 24.0 & 293.05 & 299.19 & $>17,200$ & $>17,200$ & 7,100 & $>17,200$ \\
\hline P143 & 24.4 & 312.05 & 311.64 & $>17,200$ & $>17,200$ & 15,300 & 15,100 \\
\hline P145 & 24.8 & 333.90 & 332.39 & $>17,200$ & $>17,200$ & $>17,200$ & $>17,200$ \\
\hline P147 & 25.1 & 344.34 & 349.88 & $>17,200$ & $>17,200$ & 17,000 & $>17,200$ \\
\hline P149 & 25.5 & 363.64 & 364.03 & $>17,200$ & $>17,200$ & $>17,200$ & $>17,200$ \\
\hline P150-1 & 25.7 & 371.92 & 385.71 & $>17,200$ & $>17,200$ & 14,400 & $>17,200$ \\
\hline P150-2 & 25.7 & 381.43 & 390.71 & $>17,200$ & $>17,200$ & $>17,200$ & $>17,200$ \\
\hline P152 & 26.1 & 400.21 & 392.64 & $>17,200$ & $>17,200$ & $>17,200$ & 8,700 \\
\hline P154 & 26.5 & 419.47 & 413.88 & $>17,200$ & $>17,200$ & $>17,200$ & 8,400 \\
\hline P156 & 27.0 & 438.86 & 444.56 & 15,000 & $>17,200$ & 4,200 & $>17,200$ \\
\hline P158 & 27.4 & 467.00 & 465.72 & $>17,200$ & $>17,200$ & $>17,200$ & $>17,200$ \\
\hline P160 & 27.9 & 495.58 & 497.14 & $>17,200$ & $>17,200$ & $>17,200$ & $>17,200$ \\
\hline P162 & 28.2 & 524.94 & 516.41 & $>17,200$ & 6,000 & $>17,200$ & $<2,500$ \\
\hline P164 & 28.6 & 548.04 & 547.12 & $>17,200$ & $>17,200$ & 12,600 & 7,400 \\
\hline P166 & 28.9 & 570.36 & 569.87 & $>17,200$ & $>17,200$ & $>17,200$ & $>17,200$ \\
\hline
\end{tabular}


Table C1. Channel-conveyance capacity, Puyallup, White and Carbon Rivers, western Washington, 2009._Continued

[Locations of cross sections are shown in figures A1-A12. Elevation is referenced to the North American Vertical Datum of 1988 (NAVD 88 ). Abbreviations $\mathrm{ft}$, foot; $\mathrm{ft}^{3} / \mathrm{s}$, cubic foot per second; >, greater than; <, less than]

\begin{tabular}{|c|c|c|c|c|c|c|c|}
\hline \multirow{3}{*}{ Cross section } & \multirow{3}{*}{$\begin{array}{l}\text { River } \\
\text { mile }\end{array}$} & \multirow{2}{*}{\multicolumn{2}{|c|}{$\begin{array}{c}\text { Top of bank elevation } \\
\text { (ft) }\end{array}$}} & \multicolumn{4}{|c|}{ Channel-conveyance capacity $\left(\mathrm{ft}^{3} / \mathrm{s}\right)$} \\
\hline & & & & \multicolumn{2}{|c|}{ Top of bank } & \multicolumn{2}{|c|}{ Below top of bank ( $3 \mathrm{ft}$ ) } \\
\hline & & Left bank & Right bank & Left bank & Right bank & Left bank & Right bank \\
\hline \multicolumn{8}{|c|}{ Carbon River } \\
\hline $\mathrm{C} 1$ & 0.1 & 125.64 & 130.76 & 15,200 & $>23,000$ & 9,100 & 20,400 \\
\hline $\mathrm{C} 2$ & .3 & 131.90 & 133.25 & 22,600 & $>23,000$ & 14,300 & 17,500 \\
\hline $\mathrm{C} 4$ & .7 & 136.67 & 140.89 & 19,000 & $>23,000$ & 9,200 & $>23,000$ \\
\hline C6 & 1.1 & 147.25 & 150.62 & 21,700 & $>23,000$ & 11,600 & $>23,000$ \\
\hline C8 & 1.4 & 160.08 & 162.24 & $>23,000$ & $>23,000$ & $>23,000$ & $>23,000$ \\
\hline C10 & 1.8 & 167.71 & 168.81 & $>23,000$ & $>23,000$ & 21,700 & $>23,000$ \\
\hline C11 & 2.0 & 174.53 & 176.3 & $>23,000$ & $>23,000$ & $>23,000$ & $>23,000$ \\
\hline C12 & 2.2 & 178.02 & 180.18 & $>23,000$ & $>23,000$ & $>23,000$ & $>23,000$ \\
\hline C13 & 2.3 & 181.60 & 182.52 & $>23,000$ & $>23,000$ & $>23,000$ & $>23,000$ \\
\hline C14 & 2.6 & 186.73 & 187.94 & $>23,000$ & $>23,000$ & 21,800 & $>23,000$ \\
\hline C16 & 3.0 & 196.97 & 198.22 & $>23,000$ & $>23,000$ & $>23,000$ & $>23,000$ \\
\hline C17 & 3.1 & 200.87 & 202.16 & $>23,000$ & $>23,000$ & $>23,000$ & $>23,000$ \\
\hline C18 & 3.5 & 210.48 & 208.77 & $>23,000$ & $>23,000$ & 19,700 & 10,500 \\
\hline C19 & 3.7 & 217.91 & 211.75 & $>23,000$ & 6,300 & 16,100 & $<3,000$ \\
\hline C22 & 4.3 & 239.73 & 241.35 & $>23,000$ & $>23,000$ & 16,700 & $>23,000$ \\
\hline C24 & 4.7 & 255.48 & 257.31 & $>23,000$ & $>23,000$ & 18,300 & $>23,000$ \\
\hline C26 & 5.1 & 272.84 & 274.00 & $>23,000$ & $>23,000$ & $>23,000$ & $>23,000$ \\
\hline C28 & 5.4 & 286.96 & 287.04 & $>23,000$ & $>23,000$ & $>23,000$ & $>23,000$ \\
\hline C30 & 5.6 & 296.73 & 304.65 & $>23,000$ & $>23,000$ & 17,800 & $>23,000$ \\
\hline C31 & 5.8 & 302.39 & 296.92 & $>15,000$ & 2,500 & 6,400 & $<1,900$ \\
\hline C32 & 5.9 & 306.59 & 306.56 & $>15,000$ & $>15,000$ & 6,300 & 6,200 \\
\hline C33 & 5.9 & 310.33 & 312.05 & 12,900 & $>15,000$ & 9,300 & 11,400 \\
\hline C34 & 6.1 & 322.73 & 320.85 & $>15,000$ & $>15,000$ & 12,800 & 5,800 \\
\hline C35 & 6.3 & 331.72 & 329.81 & $>15,000$ & $>15,000$ & 12,700 & 8,000 \\
\hline C36 & 6.5 & 339.49 & 339.06 & $>15,000$ & $>15,000$ & 6,900 & 6,500 \\
\hline C37 & 6.7 & 352.35 & 353.21 & $>15,000$ & $>15,000$ & 12,700 & $>15,000$ \\
\hline С38 & 6.8 & 361.99 & 365.92 & $>15,000$ & $>15,000$ & 13,000 & $>15,000$ \\
\hline C39 & 7.0 & 372.76 & 376.16 & $>15,000$ & $>15,000$ & $>15,000$ & $>15,000$ \\
\hline $\mathrm{C} 40$ & 7.2 & 385.32 & 379.66 & $>15,000$ & 9,300 & $>15,000$ & $<1,900$ \\
\hline C41 & 7.4 & 392.92 & 427.20 & $>15,000$ & $>15,000$ & $>15,000$ & $>15,000$ \\
\hline C42 & 7.5 & 403.67 & 405.32 & $>15,000$ & $>15,000$ & $>15,000$ & $>15,000$ \\
\hline C43 & 7.7 & 422.18 & 446.84 & $>15,000$ & $>15,000$ & $>15,000$ & $>15,000$ \\
\hline C45 & 8.1 & 442.85 & 458.42 & $>15,000$ & $>15,000$ & $>15,000$ & $>15,000$ \\
\hline $\mathrm{C} 47$ & 8.4 & 467.22 & 455.10 & $>15,000$ & 15,000 & $>15,000$ & 4,500 \\
\hline \multicolumn{8}{|c|}{ White River } \\
\hline W39A & 0.1 & 49.25 & 47.87 & 15,000 & 12,200 & 10,900 & 10,700 \\
\hline W40 & .2 & 55.74 & 47.52 & $>19,000$ & 11,200 & 18,800 & 10,600 \\
\hline W41 & .3 & 53.85 & 50.02 & $>19,000$ & 15,300 & 16,700 & 10,900 \\
\hline W42 & .5 & 69.95 & 60.02 & $>19,000$ & $>19,000$ & $>19,000$ & $>19,000$ \\
\hline W43 & .6 & 62.86 & 50.35 & $>19,000$ & 13,100 & $>19,000$ & 10,800 \\
\hline W44 & .8 & 69.80 & 73.30 & $>19,000$ & $>19,000$ & $>19,000$ & $>19,000$ \\
\hline W45 & 1.0 & 65.29 & 51.36 & $>19,000$ & 11,900 & $>19,000$ & 10,500 \\
\hline W47 & 1.2 & 54.03 & 54.92 & 14,200 & 15,500 & 10,900 & 11,400 \\
\hline W49 & 1.5 & 57.69 & 55.51 & 17,700 & 15,000 & 13,800 & 11,200 \\
\hline W50 & 1.6 & 53.26 & 53.64 & 11,800 & 12,200 & 10,300 & 10,500 \\
\hline
\end{tabular}


Table C1. Channel-conveyance capacity, Puyallup, White and Carbon Rivers, western Washington, 2009._Continued

[Locations of cross sections are shown in figures A1-A12. Elevation is referenced to the North American Vertical Datum of 1988 (NAVD 88 ). Abbreviations: $\mathrm{ft}$, foot; $\mathrm{ft}^{3} / \mathrm{s}$, cubic foot per second; >, greater than; <, less than]

\begin{tabular}{|c|c|c|c|c|c|c|c|}
\hline \multirow{3}{*}{ Cross section } & \multirow{3}{*}{$\begin{array}{l}\text { River } \\
\text { mile }\end{array}$} & \multirow{2}{*}{\multicolumn{2}{|c|}{$\begin{array}{c}\text { Top of bank elevation } \\
\text { (ft) }\end{array}$}} & \multicolumn{4}{|c|}{ Channel-conveyance capacity $\left(\mathrm{ft}^{3} / \mathrm{s}\right)$} \\
\hline & & & & \multicolumn{2}{|c|}{ Top of bank } & \multicolumn{2}{|c|}{ Below top of bank (3 ft) } \\
\hline & & Left bank & Right bank & Left bank & Right bank & Left bank & Right bank \\
\hline \multicolumn{8}{|c|}{ White River-Continued } \\
\hline W51 & 1.8 & 50.57 & 54.07 & 10,100 & 12,100 & 9,100 & 10,400 \\
\hline W52 & 2.1 & 55.71 & 52.46 & 12,500 & 10,400 & 10,500 & 9,300 \\
\hline W53 & 2.3 & 52.96 & 53.77 & 10,100 & 10,500 & 9,200 & 9,400 \\
\hline W54 & 2.4 & 52.33 & 55.14 & 9,500 & 10,800 & 8,200 & 9,400 \\
\hline W55 & 2.6 & 54.23 & 52.21 & 9,600 & 8,700 & 8,100 & 7,200 \\
\hline W56 & 2.8 & 53.3 & 54.29 & 8,300 & 9,000 & 7,100 & 7,300 \\
\hline W57 & 3.0 & 57.32 & 58.05 & 10,200 & 10,800 & 8,300 & 8,600 \\
\hline W58A & 3.2 & 57.57 & 58.12 & 9,700 & 10,200 & 8,200 & 8,400 \\
\hline W58B & 3.3 & 58.33 & 58.52 & 10,100 & 10,300 & 8,300 & 8,400 \\
\hline W59 & 3.5 & 55.56 & 54.70 & 8,200 & 7,800 & 7,000 & 6,600 \\
\hline W60A & 3.6 & 57.13 & 56.18 & 8,300 & 7,900 & 7,100 & 6,800 \\
\hline W60B & 3.8 & 59.70 & 59.92 & 7,800 & 8,000 & 6,600 & 6,600 \\
\hline W61 & 3.9 & 59.16 & 61.05 & 6,800 & 7,900 & 6,200 & 6,500 \\
\hline W61B & 4.0 & 60.73 & 61.04 & 7,300 & 7,500 & 6,300 & 6,400 \\
\hline W62 & 4.2 & 61.97 & 61.71 & 7,000 & 6,800 & 6,000 & 6,000 \\
\hline W63 & 4.4 & 63.62 & 64.31 & 6,300 & 6,500 & 5,600 & 5,800 \\
\hline W64 & 4.5 & 63.55 & 65.81 & 5,700 & 6,700 & 4,300 & 5,500 \\
\hline W65 & 4.7 & 66.32 & 65.89 & 5,800 & 5,500 & 4,400 & 4,200 \\
\hline W66 & 4.9 & 67.56 & 67.93 & 5,700 & 6,000 & 3,900 & 4,200 \\
\hline King Co RM 4.978 & 5.0 & 69.67 & 69.71 & 7,800 & 7,800 & 4,800 & 4,800 \\
\hline King Co RM 4.998 & 5.0 & 77.77 & 77.75 & $>19,000$ & $>19,000$ & 16,200 & 16,200 \\
\hline King Co RM 5.041 & 5.0 & 72.04 & 75.44 & 10,900 & 16,800 & 6,400 & 11,600 \\
\hline King Co RM 5.123 & 5.1 & 71.32 & 76.86 & 9,100 & 18,900 & 5,200 & 13,700 \\
\hline King Co RM 5.197 & 5.2 & 73.59 & 75.86 & 12,500 & 16,600 & 7,200 & 11,100 \\
\hline King Co RM 5.292 & 5.3 & 71.80 & 74.29 & 7,700 & 12,800 & $<3,467$ & 6,600 \\
\hline King Co RM 5.374 & 5.4 & 74.84 & 76.59 & 12,400 & 16,400 & 4,400 & 9,200 \\
\hline King Co RM 5.460 & 5.5 & 75.07 & 74.70 & 9,700 & 8,700 & $<3,467$ & $<3,467$ \\
\hline King Co RM 5.517 & 5.5 & 75.21 & 76.02 & 5,100 & 6,500 & $<3,467$ & $<3,467$ \\
\hline King Co RM 5.589 & 5.6 & 76.02 & 76.16 & 4,800 & 5,000 & $<3,467$ & $<3,467$ \\
\hline King Co RM 5.621 & 5.6 & 76.75 & 77.15 & 4,300 & 4,800 & $<3,467$ & $<3,467$ \\
\hline King Co RM 5.712 & 5.7 & 79.84 & 78.33 & 7,100 & 4,200 & $<3,467$ & $<3,467$ \\
\hline King Co RM 5.822 & 5.8 & 82.28 & 80.86 & 8,900 & 5,900 & 4,100 & $<3,467$ \\
\hline King Co RM 5.920 & 5.9 & 83.51 & 83.84 & 8,400 & 8,900 & 4,100 & 4,500 \\
\hline King Co RM 6.013 & 6.0 & 87.19 & 85.66 & 15,400 & 11,200 & 8,000 & 5,200 \\
\hline King Co RM 6.077 & 6.1 & 87.94 & 87.64 & 15,800 & 15,000 & 8,300 & 7,700 \\
\hline King Co RM 6.145 & 6.1 & 91.54 & 87.58 & $>19,000$ & 12,100 & 14,800 & 5,400 \\
\hline King Co RM 6.223 & 6.2 & 89.66 & 89.50 & 15,000 & 14,500 & 6,800 & 6,400 \\
\hline King Co RM 6.313 & 6.3 & 91.07 & 92.71 & 14,000 & $>19,000$ & 5,900 & 10,000 \\
\hline King Co RM 6.326 & 6.3 & 91.61 & 91.12 & 14,400 & 13,000 & 6,600 & 5,600 \\
\hline King Co RM 6.39 & 6.4 & 94.42 & 92.07 & 18,200 & 12,300 & 10,900 & 6,100 \\
\hline King Co RM 6.482 & 6.5 & 99.13 & 96.07 & $>19,000$ & 16,900 & 17,000 & 9,300 \\
\hline King Co RM 6.569 & 6.6 & 97.26 & 95.51 & 16,900 & 12,200 & 8,600 & 5,100 \\
\hline King Co RM 6.647 & 6.6 & 102.32 & 99.45 & $>19,000$ & $>19,000$ & $>19,000$ & 12,600 \\
\hline King Co RM 6.761 & 6.8 & 103.08 & 105.47 & $>19,000$ & $>19,000$ & 10,100 & 17,600 \\
\hline King Co RM 6.891 & 6.9 & 107.26 & 108.03 & $>19,000$ & $>19,000$ & 10,200 & 12,500 \\
\hline King Co RM 7.001 & 7.0 & 113.67 & 112.58 & $>19,000$ & $>19,000$ & $>19,000$ & $>19,000$ \\
\hline King Co RM 7.087 & 7.1 & 114.90 & 114.61 & $>19,000$ & $>19,000$ & $>19,000$ & $>19,000$ \\
\hline King Co RM 7.17 & 7.2 & 114.60 & 116.66 & $>19,000$ & $>19,000$ & $>19,000$ & $>19,000$ \\
\hline
\end{tabular}


Table C1. Channel-conveyance capacity, Puyallup, White and Carbon Rivers, western Washington, 2009._Continued

[Locations of cross sections are shown in figures A1-A12. Elevation is referenced to the North American Vertical Datum of 1988 (NAVD 88 ). Abbreviations: $\mathrm{ft}$, foot; $\mathrm{ft}^{3} / \mathrm{s}$, cubic foot per second; >, greater than; <, less than]

\begin{tabular}{|c|c|c|c|c|c|c|c|}
\hline \multirow{3}{*}{ Cross section } & \multirow{3}{*}{$\begin{array}{l}\text { River } \\
\text { mile }\end{array}$} & \multirow{2}{*}{\multicolumn{2}{|c|}{$\begin{array}{l}\text { Top of bank elevation } \\
\text { (ft) }\end{array}$}} & \multicolumn{4}{|c|}{ Channel-conveyance capacity $\left(\mathrm{ft}^{3} / \mathrm{s}\right)$} \\
\hline & & & & \multicolumn{2}{|c|}{ Top of bank } & \multicolumn{2}{|c|}{ Below top of bank (3 ft) } \\
\hline & & Left bank & Right bank & Left bank & Right bank & Left bank & Right bank \\
\hline \multicolumn{8}{|c|}{ White River-Continued } \\
\hline King Co RM 7.252 & 7.2 & 121.32 & 118.45 & $>19,000$ & $>19,000$ & $>19,000$ & $>19,000$ \\
\hline King Co RM 7.368 & 7.4 & 122.78 & 121.75 & $>19,000$ & $>19,000$ & $>19,000$ & $>19,000$ \\
\hline King Co RM 7.511 & 7.5 & 122.40 & 124.08 & 16,900 & $>19,000$ & 11,800 & 14,900 \\
\hline King Co RM 7.593 & 7.6 & 128.48 & 129.95 & $>19,000$ & $>19,000$ & $>19,000$ & $>19,000$ \\
\hline King Co RM 7.716 & 7.7 & 131.99 & 133.76 & $>19,000$ & $>19,000$ & $>19,000$ & $>19,000$ \\
\hline King Co RM 7.845 & 7.8 & 136.33 & 139.51 & $>19,000$ & $>19,000$ & $>19,000$ & $>19,000$ \\
\hline King Co RM 7.958 & 7.9 & 138.13 & 143.85 & $>19,000$ & $>19,000$ & $>19,000$ & $>19,000$ \\
\hline King Co RM 8.111 & 8.1 & 140.22 & 145.26 & $>19,000$ & $>19,000$ & 13,800 & $>19,000$ \\
\hline King Co RM 8.269 & 8.3 & 153.37 & 150.46 & $>19,000$ & $>19,000$ & $>19,000$ & $>19,000$ \\
\hline King Co RM 8.418 & 8.4 & 153.20 & 149.69 & $>19,000$ & $>19,000$ & $>19,000$ & $>19,000$ \\
\hline King Co RM 8.561 & 8.5 & 154.33 & 155.70 & $>19,000$ & $>19,000$ & 17,100 & $>19,000$ \\
\hline King Co RM 8.707 & 8.7 & 162.41 & 170.70 & $>19,000$ & $>19,000$ & $>19,000$ & $>19,000$ \\
\hline King Co RM 8.821 & 8.8 & 165.19 & 175.99 & $>19,000$ & $>19,000$ & $>19,000$ & $>19,000$ \\
\hline King Co RM 8.946 & 8.9 & 168.25 & 163.56 & $>19,000$ & $>19,000$ & $>19,000$ & 12,100 \\
\hline King Co RM 9.125 & 9.1 & 172.22 & 181.28 & $>19,000$ & $>19,000$ & $>19,000$ & $>19,000$ \\
\hline King Co RM 9.311 & 9.3 & 178.61 & 193.47 & $>19,000$ & $>19,000$ & $>19,000$ & $>19,000$ \\
\hline King Co RM 9.477 & 9.4 & 183.12 & 198.29 & $>19,000$ & $>19,000$ & $>19,000$ & $>19,000$ \\
\hline King Co RM 9.794 & 9.7 & 194.25 & 201.66 & $>19,000$ & $>19,000$ & $>19,000$ & $>19,000$ \\
\hline King Co RM 10.06 & 10.0 & 202.14 & 226.80 & $>19,000$ & $>19,000$ & $>19,000$ & $>19,000$ \\
\hline King Co RM 10.34 & 10.3 & 206.73 & 211.77 & $>19,000$ & $>19,000$ & 10,000 & $>19,000$ \\
\hline King Co RM 10.59 & 10.5 & 216.95 & 221.00 & $>19,000$ & $>19,000$ & $>19,000$ & $>19,000$ \\
\hline
\end{tabular}


Publishing support provided by the U.S. Geological Survey

Publishing Network, Tacoma Publishing Service Center

For more information concerning the research in this report, contact the Director, Washington Water Science Center

U.S. Geological Survey

934 Broadway, Suite 300

Tacoma, Washington 98402

http://wa.water.usgs.gov 
